\title{
GEOLOGY OF THE STATE OF MORELOS AND CONTIGUOUS AREAS IN SOUTH-CENTRAI MEXICO
}

\author{
by
}

Carl Fries, Jr.

A Thesis Submitted to the Faculty of the DEPARTMENT OF GEOLOGY

In Partial Fulfillment of the Requirements For the Degree of DOCTOR OF PHILOSOPHY

In the Graduate College UNIVERSITY OF ARIZONA

1958 


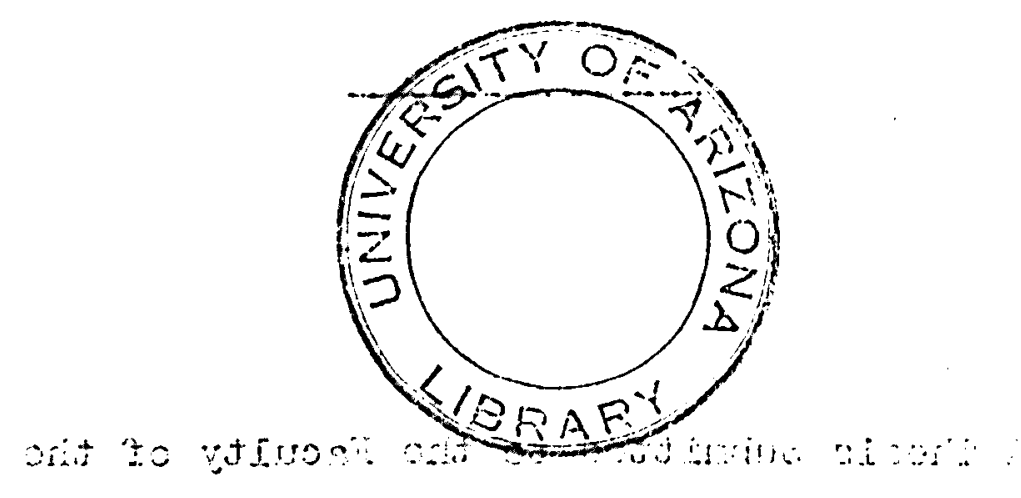


This thesis has been submitted in partial fulfillment of requirements for an advanced degree at the Univer81 ty of Arizone and 18 deposited in the University Library to be made avallable to borrowers under rules of the L1brary.

Brief quotations from this thesis are allowable without special permisBion, provided that accurate acknowledgment of source is made. Requests for permission for extended quotation from or reproduction of this manuseript in whole or in part may be granted by the head of the major department or the Dean of the Graduate College when in their judgment the proposed use of the material is in the interests of scholarshlp. In all other instances, however, permission must be obtained from the author.

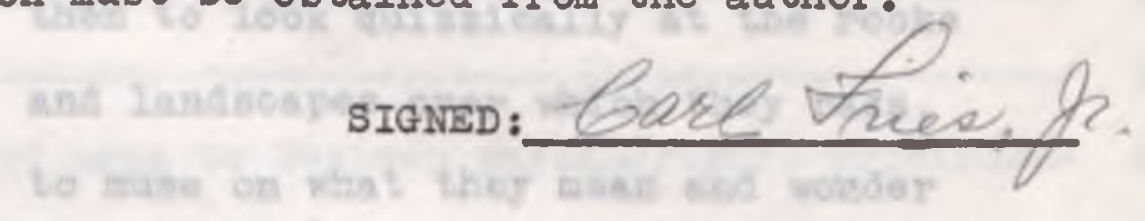

APPROVAL EY THESIS DIRECTOR

low:

Th1s thes1s has been approved on the date shown be-

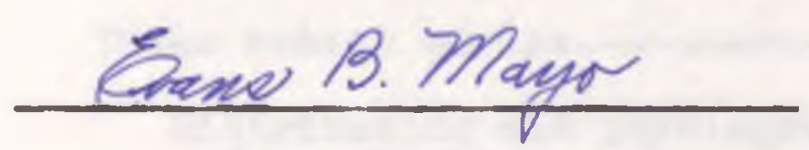

Evans B. Mayo Professor of Geology

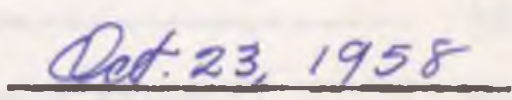

Date 


\section{DEDICATION}

To my fellowmen, who, on excursions into the countryside, pause now and then to look quizzlcally at the rocks and landscapes over which they pass, to muse on what they mean and wonder what processes contributed to their development. 
CONTENTS

Page

Abstrect-1.

Introduction-... 6

Location and access-n... 6

Culture-n- 9

Object1ves_n 11

Previous studies-nnon 12

History of the study and procedures followed........ 13

Acknowledgments-_._- 20

Physlography-_- 23

Relation of area to Mexican physiographic provinces- 23

Climate and vegetation 25

Drainage-_- 29

Modern drainage-_._- 29

Pre-Plelstocene dralnage-n_- 30

Land forms-n_. 32

Sedimentary, volcanic, and metamorphic rocks____._._. 37

General features- 37

Taxco schist series-__-_._- 42

Distribution and physiographic expression-...... 42

Petrography and thicknesg-_an 43

Metamorph1sm and origin____._. 44

Age and correlation- 45 
CONTENTS--Cont1nued

Page

Sedimentary, volcanlc, and metamorphic rocks--Continued

Taxco Viejo green rolcanic series-_............... 46

Distribution-... 46

Lithology, thickness, and origin-............... 46

Age and correlation-_._. 48

Acahuizotla formation-_._. 49

Distribution and I1thology-a. 49

Age and correlation-_._. 51

Acuitlapán formation-_._. 52

Distribution, 11thology, and thickness-......... 52

Stratigraphic relationships, age, and correlation 53

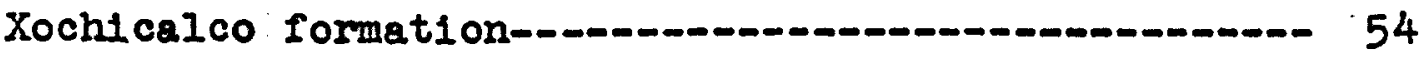

Distribution and physiographic expression...... 54

Lithology and thickness-n_. 56

Stratigraphic relationships and metamorphism-..-. 57

Fos8118, age, and correlation $\ldots \ldots \ldots$

Morelos formation-_._. 61

Distribution and physlographic expression-...... 61

It thology of the carbonate member-........... 63

Dolomitization and silicification-........... 65

Weathering-_._. 68

Anhydrite member-_an 69

Th1 clmess- 71 


\section{CONTENTS--Continued}

Sedimentary, volcanic, and metamorphic rocks--Continued

Morelos formation--Continued

Structure and stratigraphic relationships_....... 73

Foss11s and agenn 74

Correlation-_._. 82

Cuautla formation-_._. 83

Distribution and physlographic expression-....... 83

If thology-_.... 86

Thickness-_- 89

Stmucture and stratigraphic relationships-....-.- 90

Fossils and age-_._._. 91

Correlation-_. 100

Mexcala formation-_. 102

Distribution and physiographic expression-......- 102

Iithology and thickness-_._- 105

Stratigraphic relationships, structure, and metamorph1sm-_... 108

Fos81Is and age-n_. 111

Correlation-....... 122

Balsas clastic group-_..._. 124

Distribution and physiographic expression........ 124

L1 thology and thickness 127

Structure, stratigraphic relationships, and age-- 132

Correlation-_..._- 135 


\section{CONTENTS--Continued}

Page

Sedimentary, volcanic, and metamorphic rocks--Continued

Middle Tertiary volcanic units_n_... 140

General features-n_n 140

Tilzapotla rhyolite series_.

Distribution, petrography, and thickness-...- 143

Stratigraphic relationships, age, and corre-

lation-- 146

Tepoztlán formation-_. 149

Distribution, petrography, and thickness-....- 149

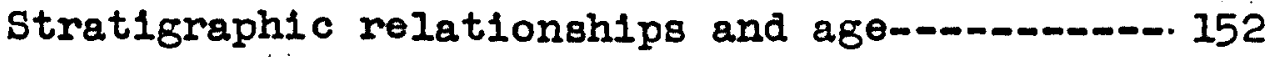

Origin and correlation 155

Buenavista volcanic serles-n_n 157

Undifferentiated volcanic series-n 161

Zempoala andesite series-_an 164

Distribution, petrography, thickness, and age- 164

Correlation-_ 166

Cuernavaca formation

Distribution, 11thology, and thickness-......... 168

Stratigraphic relationships, origin, and age-...- 174

Correlation- 176

Chichinautzin basalt series-_. 178

Distribution and physlographic expression........ 178

Petrography and thickness-a 180

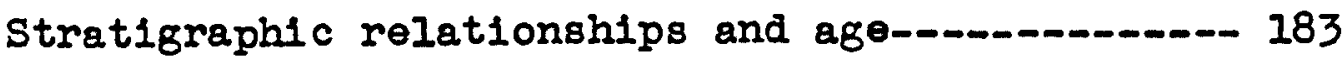


CONTENTS--Cont1nued

Page

Sedimentary, volcanic, and metamorphic rocks--Continued

Chichinautzin basalt series--Continued

Correlation-

Continental clastic deposits

Definition- 188

Description of separate areas of clastic deposits 189

Summary of origin of mapped clastic deposits-.--- 192

Solls, caliche, and minor unmapped Recent deposits-- 193

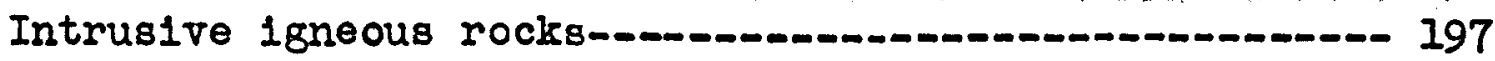

Pre-Cretaceous dikes and sills-_-_._- 197

Cretaceous(?) or early Tertiary(8) stocks-......... 198

D1stribution and petrography-_.............. 198

Time of emplacement__._. 199

Tertiary dikes, sills, and stocks-n............ 202

Pre-Tilzapotla(?) intmusive rocks-_. 202

Post-Balsas intrusive rocks-_. 204

Structure-n- 207

General features-_-_n- 207

Folds-_- 209

Description of trends and types of folds-........ 209

Origin and age of folds_. 213

Faults-_- 218

Faults of pre-Balsas or early Balsas and postCretaceous age-... 219 
Structure--Continued

Faults--Continued

Failts of post-Balsas and pre-Plelstocene age-n-- 222 Faults of post-Pliocene age and the Neo-volcanic

Belt_-_._. 223

Geolog1c history-_an 227

Mineral resources-_an 235

Keterence works clted._.

Appendix-1_- 248

Provenance, petrographlc description, and faunal content of rock samples cited in the text-_....... 248

List of samples collected from the rock formations in the area mapped and cited in the text-....... 307

Metric equivalents-_an 309

Plates 4 through 22 310

\section{ILIUSTRATIONS}

Figure 1. Index map of the region between México, D. F. and Acapulco, Guerrero_._._. 7

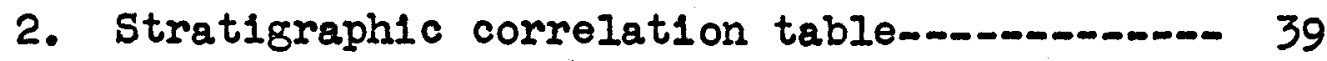

Plate 1. Geologic map of westerm Morelos and extreme north-central Guerrero, Mexico-_._..... pocket

2. Geologic sections through westerm Morelos and north-central Guerrero, Mexico-...... pocket 
Plate 3. A, Index map of Mexico showing location of area mapped and of stratigraphic sections c1ted. B, Map showling location of volcanic cinder cones, trace of axial planes of anticlines and synclines, faults, and assumed pre-Plelstocene drainage lines-.-- pocket

4. ObIlque trimetrogon air photograph looking N. 330 E. from a position about $4 \mathrm{~km}$. south of the Amacuzac River........... 311

5. Oblique trimetrogon air photograph looking N. $33^{\circ} \mathrm{E}$. Irom a position about $4 \mathrm{~km}$. south of Xicotiacotla on the Amacuzac River-_..-

6. Oblique trimetrogon air photograph looking S. $33^{\circ} \mathrm{W}$. from a position about $5 \mathrm{~km}$. north of Santa $\mathrm{Fe}$ along the AmacuzacIguala toll road-_.....

7. Oblique trimetrogon air photograph looking S. $33^{\circ} \mathrm{W}$. Irom a position about $4 \mathrm{~km}$. north of Acultlapén on the Amacuzac-Taxco highway-_.

8. Photomicrographs of low-grade schists and welded tuffs-......

9. Photomicrographs of low-grade $8 \mathrm{chl}$ st and welded tuffs-......

10. Photographs showing texture of dolomitized I1mestone from the Morelos formation-..... 317

11. Photographs showling texture of limestone and dolomite from the Morelos formation-.....- 318

12. Photograps showling texture of I1mestone from the Morelos formation_..._._. 319

13. Photographs showling texture of dolomitized limestone from the Morelos formation, and a basal carbonate conglomerate from the Cuautla formation-_.... 


\section{ILIUSTRATIONS--Continued}

Plate 14. Photographs showlins texture of basal calcarenite and rudistid limestone from the Cuautla formation-_... 321

15. Photographs showing texture of sedimentary rocks from the Cuautia and Mexcala formations and the Balsas clastic group-...... 322

16. Photographs of mudistids in weathered outcrops of the Cuautla formation-_._._. 323

17. Photographs of rudistids in weathered outcrops of the Cuautla formation-......... 324

18. Photomicrographs of sedimentary rocks from the Mexcala formation, the Balsas clastic group, and the Cuernavaca formation-....- 325

19. Photomlcrographs of andes1te flow rocks and rhyolite tuff-_... 326

20. Photomicrographs of intmusive diabese and basalt flow rocks__._. 327

21. Photomicrographs of dacite, andesite, and basalt flow rocks

22. Photomicrographs of olivine basalt flow rocks 
GEOLOGY OF THE STATE OF MORELOS AND CONTIGUOUS AREAS IN SOUTH-CENTRAI NEXICO

By Carl Fries, Jr.

\begin{abstract}
The area described I1es in south-central Mexico and embraces all but the southeastern corner and easternmost border of the State of Morelos, the second smallest State in the Mexican Republic. It includes small contiguous parts of the State of México, in the northeastern corner, and of the State of Guerrero in the southwestern corner. Iimlting geographic coordinates are $98^{\circ} 45^{\circ}$ to $99^{\circ} 39^{\prime}$ west longitude and $18^{\circ} 18^{\prime}$ to $19^{\circ} 08^{\prime}$ north latitude, the northern boundary being only $35 \mathrm{~km}$. south of Mexico City, capital of the Republic. The geologic map does not cover the entire rectangle outlined, but is irregular in form and measures roughly $4150 \mathrm{sq} . \mathrm{km}$., three-quarters of 1t representing twothirds of the State of Morelos and the rest lying outside the State.
\end{abstract}

The region ranges in altitude from $730 \mathrm{~m}$. above sea level at Iguala near the south edge of the map, to a general level of about $3000 \mathrm{~m}$. at the north edge, although individual peaks rise to $3900 \mathrm{~m}$. and Popocatépetl Volcano, a few 
kllometers east of the northeastern border of the map, rises to $5452 \mathrm{~m}$. above sea level. Annual rainfall ranges from a minimum of about $640 \mathrm{~mm}$. In the low country, to $1200 \mathrm{~mm}$. and more at altitudes above $2000 \mathrm{~m}$. Most of $1 \mathrm{t}$ falls in summer between June and September. Winter frosts are rare below $1800 \mathrm{~m}$. The climate is of savanna to steppe type; solls are thin and may be classified as belonging to the tschernosem group, w1th strong development of calcareous evaporites (callche) at altitudes below $1800 \mathrm{~m}$.

The northern border of the area forms the southern half of the late Pliocene to Recent Neo-volcanic Belt of basic volcanism that crosses Mexico in the direction N. $80^{\circ}$ W., and thus has constructional topography. The rest of the area belongs to the Balsas Basin physlographic province, which is characterized by maturely dissected terrain tributary to the large Balsas River. All but the southwestern corner of the area drains southward via the Amacuzac River Into the Mexcala-Balsas River, and thence westward into the Pacific Ocean. The southwestem corner drains directly into the Balsas River via the Iguala River. Local relief is of the order of 300 to $600 \mathrm{~m}$. The mature topography was partly buried by late Pliocene alluvium in the central part of the area, owing largely to local volcanism. Dissolution of limestone, dolomite, and anhydrite of the Cretaceous formations has produced sinks and poljes, some of which contain small lakes. Other karst features are also common, such as caves, 
caverns, underground rivers, and surficial lapies or karren. Drainage blocking by lava and polje development in late Plelstocene and Recent time produced new alluvial flats in this otherwise dissected region.

The oldest rock unit in the region is the Taxco schist series of late Paleozolc(?) age. It was folded, metamorphosed, follated, intruded by dikes, and strongly eroded before the next unit, the Taxco Viejo green volcanic serles of Late Triassic(?) age, was deposited. Another perlod of metamorphism and erosion followed before the calcareous clast1c sediments of the Dpper Jurassic(?) Acahuizotla formation were la1d down. The next unit consists of the partly phyllitic calcareous shale of the Acuitlapán formation, which is of Neocomian(?) age and rests with at least disconformity on the Acahuizotla formation. The overlying Aptian-Barremian Xochicalco formation of thin-bedded limestone appears to grade upward from the Acultlapán formation, locally, but it seems to be unconformable elsewhere. All these units have small outcrops in the area mapped and were not studied in detall.

Warping and erosion occurred before the overlyins Morelos formation began to accumulate in early Albian time. The basal member is anhydrite in the eastern part of the area mapped, but IImestone and dolomite were deposited elsewhere. The formation consists largely of shallow-water calcareous bank deposits, with a maximum thickness of about 900 
m. Deposition ceased in early Cenomanian time and further warping occurred, possibly accompanied by intrusion of the Coxcatian, Buenavista, and Colotepec granitic stocks. The next formation consists of the Cuautla limestone of Turonlan age, which rests disconformably upon the Morelos formation. It represents a thick calcareous bank (750 m.) in the eastern half of the area mapped, but westward it wedges out and interfingers with the overlying calcareous clastic sediments of the Mexcala formation, which may be of latest Turonian age at the base in some places and of early Coniaclan age elsewhere. The Fexcala formation is at least $1200 \mathrm{~m}$. thick and accumulated until santonian or possibly Campanian time, when the region was uplifted and was not again submerged.

A period of strong folding occurred probably in early and middle Eocene time, concomitant with the Laramide folding farther north. As folding tapered off, intrusion of dikes and stocks, strong faulting, and extrusion of basic lavas began, accompanied by accumulation of thick (more than $2000 \mathrm{~m}$.$) clastic deposits of the Balsas group on down-$ faulted blocks in latest Eocene and early oligocene time. Rhyolitic volcanism then commenced in the south to form the Tilzapotia rhyolite series, and intermediate volcanism soon began all over the region, forming the Tepoztlán formation, Buenavista volcanic series, Zempoala andesite series, and other Undifferentiated volcanic rocks, all of latest 0l1go- 
cene to earliest Pliocene age. Local unconformities developed between the units, and dikes and small stocks were emplaced here and there.

Renewed faulting, outbreak of Nevado de Toluca (X1nantécatl) and PopocatépetI Volcanoes, and accumulation of the Cuernavaca formation followed in middle and late Pliocene time. Basaltic volcanism then began in the Neo-volcanic Belt and cut off drainage from what is now the upper Lerma valiey and the former Nexico valley, reversing drainage in the former and turning the latter into an endorelc basin. Deposition of the Cuernavaca formation was halted, and the basaltic range along the northern border of the area was bullt. The Neo-volcanic Belt is thought to be a part of Menard's Clarión fracture zone of the Pacific Basin, as already suggested by him, but its age inland is not belleved to be older than middle Pliocene. The belt is thought to represent the surficial expression of incipient left-lateral transcurrent faulting in the subcrust. Activity continues along it to the present day. 


\section{INTRODUCTION}

Location and access

The region described in the present report lies in south-central Mexico and has limiting geographic coordinates of $98^{\circ} 45^{\prime}$ to $99^{\circ} 39^{\prime}$ west longltude and $18^{\circ} 18^{\prime}$ to $19^{\circ} 08^{\prime}$ north lat1tude (see pl. 3-A and 11g. I). Its northern border 1 s only $33 \mathrm{~km}$. south of the center of México, D. F., the capital of the Republic of Mexico, and Its southern limit $1 \mathrm{~s} 95 \mathrm{~km}$. farther south. Its maximum width from east to west is $94 \mathrm{~km}$. The area mapped that is included in the present report is irregular in outline and covers only about half the terrain within the quadrangle fixed by the coordinates given. It measures roughly $4150 \mathrm{sq} . \mathrm{km}$., of which some $3200 \mathrm{sq}$. km. are in the state of Morelos and the rest are in the States of México and Guerrero. About two-thirds of Morelos, the second smallest State in the Republic, is covered by the geologic map; the remalning onethird consists largely of the southeastern corner of the State, where access is difficult and air photographlc coverage was incomplete and unsultable for detalled mapping at the time fleld work was done. Reconnalssance traverses and further detalled mapping in areas not included on the map in plate 1 were carried on by the writer for distances of several kilometers to as much as $40 \mathrm{~km}$. to the north, 


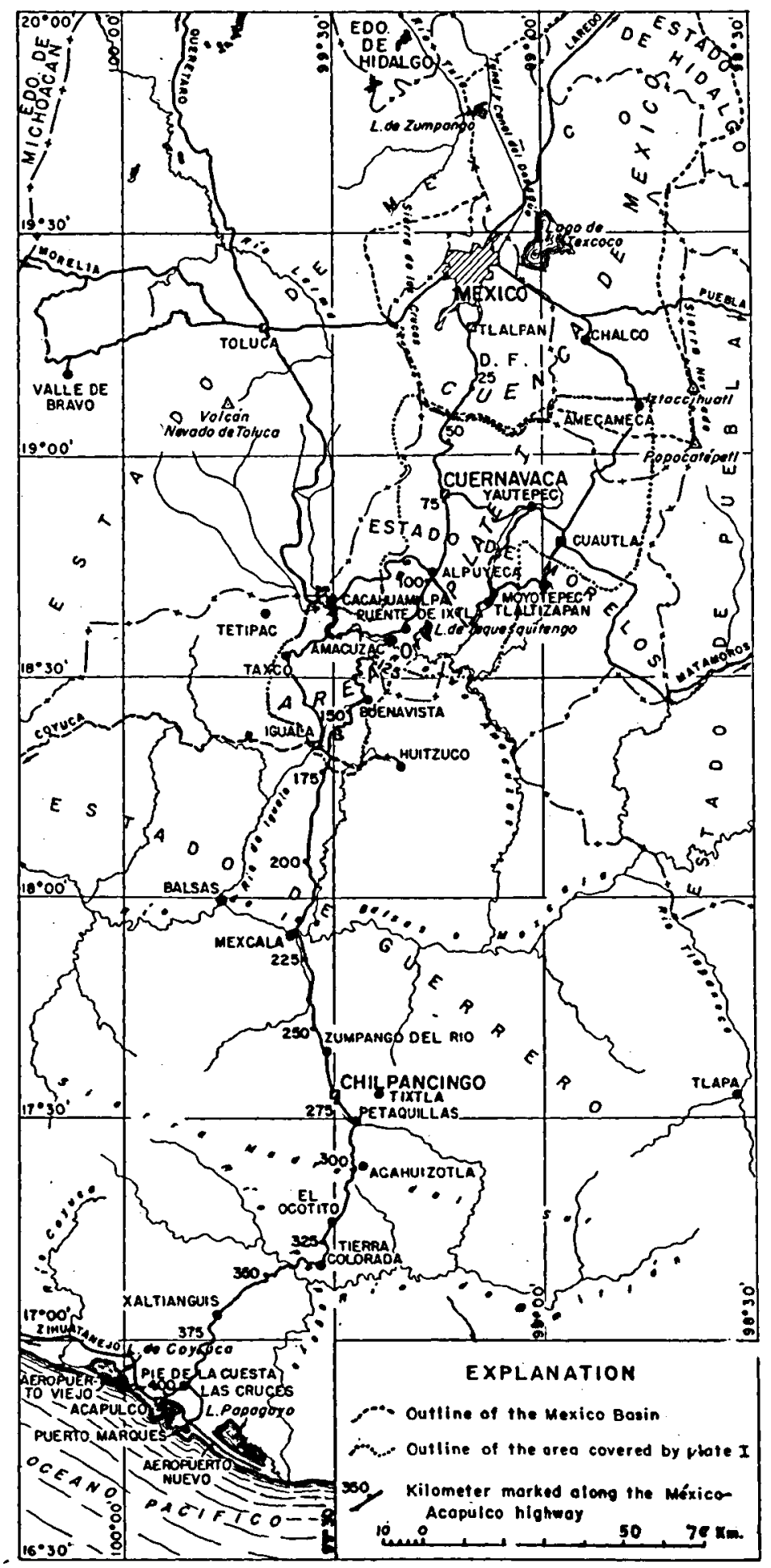

Figure 1. Index, mop of the region between México, D.F. and Acapulco, Guerrero. 
east, south, and west. Reference wIll be made to some of these outlying points at appropriate places in the text.

Three paved highways lead southward from the Mexico Basin into the area mapped. Two of them run parallel to each other between Mexico City and Cuernavaca, one being a federal highway and the other a four-lane, divided turnpike; the third one leads from Mexico City through Amecameca to Cuautla. From the latitude of Cuernavaca-Cuautla, a network of six paved highways spreads southward to the latitude of the Amacuzac River, where it converges and gives way to two pared roads leading southward to Iguala. Two of the highways in Morelos run parallel to each other between Cuernavaca and Amacuzac; the western one is a federal road, and the eastern one is a broad toll road. The two hlghways leading southward from Amacuzac consist of a federal road through Taxco and a toll road directly to a point $3 \mathrm{~km}$. east of Iguala. At this latter point the two join and continue southward as one broad federal road to Acapulco on the Pacific ocean. Several paved roads connect the north-south system in the State of Morelos, but only one leads eastward from the area mapped, starting at Cuautla, and only one leads westward, starting at Cacahuamilpa. Besides the paved highways mentioned, many dirt roads and trails passable by Jeep penetrate other parts of the reg1on. Few points are farther than $5 \mathrm{~km}$. from a road, with the exception of the area between Buenavista de Cuéliar and 
Taxco, which is about $22 \mathrm{~km}$. across and is inaccessible except by foot or horse.

Two rallroads traverse the region. A narrow-gage road enters from Mexico City by way of Amecameca to Cuautla and continues eastward into the State of Puebla. A branch goes to Yautepec, Tlaltizapán, Zacatepec, and Puente de Ixt1a, where it terminates. The other line, a stardard-gage road, enters from Mexico City through Tres Cumbres to Cuernavaca and continues southward through Puente de Ixtla to Iguala and thence to station Balsas on the Balsas River, where it terminates.

\section{Culture}

The State of Horelos has a total area of $4964 \mathrm{sq}$. km. and a population of nearly 300,000 inhabitants, making a population density of about 60 persons to the square k11ometer. Cuernavaca, the capital of the state, has probably 35,000 inhibitants or more, and Cuautla, the second largest c1ty, has more than 10,000 inhab1tants. Other important cities with several thousand inhabitants each are zacatepec, Jofutia, Yautepec, Tepoztlán, Miacatián, Cocoyoc, Puente de Ixtla, Tlaquiltenenso, and Tlaltizapán. The part of the State of Guerrero included in the area mapped has only three c1t1es of several thousand 1nhabltants or more: Iguala, with about 20,000 people, and Buenavista de Cuéllar, with only a few thousand people, and well know Taxco. 
The principal industry in the area mapped is agriculture, and second in importance is mining. The region has a large production of sugar cane, which is processed into sugar mainly in mills located at Zacatepec, Oacalco, Casasano, and Cuautla. Other Important products are rice, corn, beans, tomatoes, melons, chiles, tropical frults, truck regetables, and honey. Animal products include cattIe, sheep, goats, hogs, chickens, and turkeys. Lumber is obtained on a minor scale in the high mountains along the northern border of the area mapped. A Portland-cement plant is located north of X1utepec, and lime is bumed in large kilns south of there and near Acatlipa. Metal mining is carried on only in the Taxco district and east of there. Non-metallic minerals and stone are mined or quarried in different places.

The tourist industry is of considerable importance to the economic life of the region; probably the income from Mexican nationals who leave Mexico City on weekends for lakes, springs, rivers, and caverns in the area mapped 1s greater than that from foreign tourists. Favored points are springs at Cuautla, Oaxtepec, Las Estacas, Tehuixtla, Tlaltizapán, Palo Bolero, and Fuente Quebrado; other points are the Zempoala Lakes, Lake Tequesquitengo, the Cacahuamilpa Caverns, the San Antón Falls, and the archaeological sites at Xochicalco, Teopanzolco, and Tepoztlán, as well as the picturesque cities of Taxco and Tepoztlán. Arts and 
crafts provide another source of income, particularly weaving, embroidery, basketry, motal working in silver and gold, ceramic ware, and setting of semi-precious stones in silver and gold jewelry.

\section{Objectives}

The objectives sought in making the present study were several-fold: 1) to define and to map the rock units present in a hitherto unmapped region bounding Mexico City on the south, 2) to leam the types and ages of folding and faulting that affected these units; 3) to attempt to learn more about the origin and age of the interior drainage basin in which Mexico City is located; 4) to establish the relationship between the structure of the pre-Tertiary rocks and the belt of late Cenozolc basaltic volcanism that crosses Mexico from west to east at about the I9th parallel of latitude, which in this area forms the northern border of the map; 5) to obtain the broad relationships between the rock units, the tectonic history, and the mineral deposits of the region; and 6) to learn something about the paleogeography of the region in Cretaceous time, as evinced by facies and thickness changes of the Cretaceous rocks.

A further incentive for carrying on the study was the need for preparing geologic excursions out of Mexico City for those who were to attend the International Geological Congress held in Mexico in August-September 1956, and, 
In fact, five different excursions were routed into or through different parts of the area mapped. St1ll another factor was the desire to have an area studied and mapped near Mexico City, in which a varlety of rocks and structures, as well as other geologic features, could be readIly demonstrated to geology students of the National UnIVersity and Polytechnic Institute, as part of their course work.

\section{Previous studies}

The writer knows of no earlier-published detailed description and geologic map of the region covered in the present report, except a greatly reduced, small-scale (1:50,000) map of the Taxco mining district in a report by Fowler and others (1948), and a detailed map of a small area northeast of Taxco by Edwards (1955), who studied the early Tertlary red conglomerate in that area. The 1942 edition of the Geologic Map of Mexico, as well as earlier edItlons, shows small patches of Cretaceous rocks and undifferentiated Tertiary rocks on a scale of $1: 5,000,000$, probably sketched on the basis of broad reconnaissance traverses made near the turn of the present century. Reports on geologic features, without geologic maps, include a description by Bárcena (1875, p. 374-376) of a species of Hippurites found near Yautepec; a brief geologic and physlographic description by Salinas-Salazar (1922) of an excursion from 
Mexico City to Cuernavaca and the Cacahuamilpa Caverns; a paper by Ordóñez (1937a) on the San Antón Falls over a basalt flow in Cuernavaca; a discussion by Oróñez (1937b) of the rocks and physlographic forms near Tepoztlán; a report by Müllerried (1944) on the rocks and fossils near Cacahuam1Ipa; a paper by Foshas and others (1946) of the fluorite deposits and geology of a small area northeast of Taxco; a description by wüllerried (1950) of Durania cornupastoris (Des Moulins) Parona, found in Iimestone at Los Hornos a few kllometers east of Elotes, beyond the edge of the geologic map in plate 1; a paper by Lozano-Garcia (1953) on erosion forms at Tepoztlán; and a detalled description by Bonet (1956) of the Cacahuamilpa Caverns. The latter publication contains an excellent bibllography of the numerous earlier papers in which Cacahuamilpa is mentioned.

History of the study and procedures followed

The writer became interested in the area mapped as a result of the discovery by a local prospector, in the summer of 1947, of the mineral portlandite $\left(\mathrm{Ca}(\mathrm{OH})_{2}\right.$ ) (Faust and others, I950, p. 614) along the southeastern contact of the Cerro de la Corona volcanic neck with limestone beds (quad. D-7) which were later to be found to correspond to the basal part of the Cuautla formation. Abundant silicified fossils were noted in the limestone, and the locality was later recommended to Carl F. Bauman, Jr., a graduate student 
at Columbia University, as sultable for a paleontologic study. Bauman collected silicified maistids from the 10cality in the summer of 1949 and described them in an unpublished thes1s for the degree of Master of Arts at Columbia University in 1950. OnIy two of the species described appear to be new, and these have been published in a separate paper (Bauman, 1958).

The discovery of portlandite and the work by Bauman polnted up the lack of and need for stratigraphic and structural information on this region, which lies only a short distance from Mexico City, and the writer decided to attempt to define the rock units and decipher the structure in whatever time could be spared from other duties. The nearest local1ty in which the rocks had been grouped into formations or mappable units was the Taxco mining district, where Foshag and otherg (1946) and Fowler and others (1948) had distinguished and briefly described several broad units consistIng of schist, Iimestone, shale, red conglomerate, volcanic rocks, alluvium, and several kinds of intrusive dikes and sills, but without naming formations or fixing their ages on fossil evidence. No attempt was made at first to correlate the rocks of the area east of Cuernavaca w1th those of the Taxco district, and the two were not, in fact, tied together until five years later, after formations had been defined in the north and could be carried southward. The fleld study and mapping were begun around Cerro 
de la Corona (quad. D-7) in March 1950, on vertical air photographs at a scale of about $1: 30,000$, which belons to a series of trimetrogon photographs taken in 1943 and 1946 by the United States Air Force in cooperation with the Mexican Department of Defense. The trimetrogon flight lines run about west-northwest and are spaced generally from 20 to $25 \mathrm{~km}$. apart, although changes in direction during the flights make the spacing irregular between any two lines. Five lines of flight cross the area mapped; the northernmost one is over the Morelos State line north of Cuernava$c a$, and the southernmost one is over Lake Tuxpan near the south end of the map in plate 1. The oblique photographs of the trimetrogon triplets were found to be difficult or even impossible to use for detailed mapping in most places (see pls. 4-7 for examples of these photographs), and vertical photographs were obtained from other sources as they became available during the course of the work.

The most extensive group of vertical photographs used consists of more than 1100 photographs on a scale of about 1:12,500 covering the terrain from the latitude of Cuernavaca (quad. C- $\sigma$ ) southward to Tehuixtla on the Amacuzac River (quad. H-5), and from the longitude of Yautepec (quad. D-8) westward to Cuernavaca, with a further extension westward to the tow of Amacuzac (quad. G-4) at the south end of the area flown. The flight was made by the Cla. Mexicana Aerofoto in 1941, for the Banco Nacional de Crédito 
Ejidal, over lands producing sugar cane processed in the mill at Zacatepec. The company mentioned had made an uncontrolled mosaic on a scale of about $1: 18,000$, to which all the data from the individual photographs were transferred and which served as a nucleus around and to which were added areas mapped on other photographs.

A series of 58 vertical photographs in a belt about $8 \mathrm{~km}$. wide extending from Huitzilac (quad. B-5) eastward

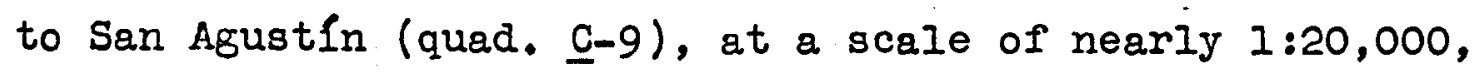
served to f1II in the area between two trimetrogon flights. These photographs were taken in 1951 by the Cartographic Depertment of the Mexican Army. A mosaic on a scale of $1: 10,000$, made by the Cla. Mexicana Aerofoto in the early $40^{\prime} \mathrm{s}$ for the Peña Pobre paper plant in Mexico City, was used for an area $12 \mathrm{~km}$. Iong from north to south by $6 \mathrm{~km}$. wide in the northwestern corner of the map in plate 1 . A flight Iine of vertical photographs at a scale of about 1:15,000, taken by the Cla. Mexicana Aerofoto in 1953 along the highway north of Tres Cumbres (quad. B-6), was used to tie together and fill in between the other photographs mentioned.

A series of 26 vertical photographs in a flight line from the Amacuzac River (quad. G-4) southward over the toll road to the Iguala valiey (quad. $J-2$ and $J-3$ ) was used to map detail in that area and to tie together trimetrogon flights at the north and south ends of the strip. These 
photographs were taken by the Cla. Mexicana Aerofoto in the early 50's before the highway was constructed. Three lines of flight containing 20 vertical photographs in a belt between $\mathrm{Km} .157$ and $\mathrm{Km}$. 166 of the highway near Taxco (quad. H-l), at a scale of about 1:5,000, were used to obtain certain contacts not shown on the map by Fowler and others (1948) and to tie together two very widely spaced trimetrogon flight lines. This group of photographs was taken in 1949 by the Cla. Mexicana Aerofoto.

Active fleld work was carried on for a total of 19 days between Narch and May 1950. Work was then interrupted and was not resumed until November 1953, when 1t was carried on intermittently until early June 1954 for a total of 45 days. Fleld work was resumed on August $I$ and continued until July 10 of the following year (1955), during which time 60 days were spent in all. Between September 24, 1955 and January 7, 1956 a total of 28 more days was spent in the fleld. Thus an overall total of 152 days was spent in actual fleld mapping, which equals six months of six-day weeks.

Construction of the final map was not begun until the fall of 1955, after most of the area had been mapped on air photographs, and work continued on it intermittently until July 1956, when a simplified version was printed for use In various excursion guidebooks of the International Geological Congress held in Hexico City in August and September 
of that year. Various details were added, errors were corrected, and the map was completed nearly in its present form during the fall and winter of 1956-57, and the geologic sections were also constructed at that time. A suitable planimetric base map was not avaliable, and consequently the entire map was constructed from the photographs with the aid of a mechanical triangulator and roughly located geographic coordinates of points scattered over the area. Vertical and oblique sketchmasters were used to sketch in planimetry and geology, and small areas constructed at different scales were adjusted to the scale of final compilation $(1: 75,000)$ either photographically or with a focalmatic projector. The map thus contains errors in planimetric positions in some areas, but relationships between planimetric features and geologic contacts are thought to be well shown.

Special efforts were made during the first field season to search for and to collect as much fossillferous material as could be found, for identification by special1sts and to serve as a guide in establishing the geologic section. In view of the rather complete silicification of many maistids and other invertebrates, limestone blocks were collected and dissolved in hydrochloric acid to release the fossils contained, some of which were fairly well preserved. Chips of limestone for microfossil study in thin section, as well as bulk shale samples, were sent to other specialists. The results of these investigations 
permitted much more rapid advance when field work was resumed three years later. During the last two years of field work (1955-56), attention was paid mainly to microfauna in the Cretaceous carbonate rocks, and comparisons were made with microfauna from rocks of the same general age and I1thology farther north and in eastern Mexico, in an attempt to establish the upper and lower age limits of the formations.

Petrographic study of rock thin sections was not made until late in 1955 and early in 1956. Because of the press of other duties and the lack of time, this work was done by a specialist at the writer!s request. After the Congress in September 1956, other rocks were selected for sectioning and study, and a zircon concentrate was made of the Tilzapotla rhyolite for radiometric age determination. Petrographic studies of these rocks were made by the writer in the spring and early summer of 1958. Also during this latter period, studies were made of the distribution of dolomite in the Iimestone, and photomicrographs of rock sections and photographs of carbonate textures were made for 1llustrative purposes.

Relatively brief texts summarizing the geology of the area studied were prepared early in the summer of 1956 for inclusion in excursion guidebooks for the International Geological Congress in August and september. Detailed road logs were also prepared and included in the guidebooks. The 
excursions for which these materials were used are as follows: Excursions $\mathrm{A}-4$ and $\mathrm{C}-2$, Geology along the highway between México, D. F. and Taxco, Guerrero; Excursions A-9 and C-12, Geology along the highway between México, D. F. and Acapulco, Guerrero, via Taxco and Chilpancingo, Guerrero; and Excursion C-9, Plelstocene volcanoes, clastic sediments and volcanic rocks of Cenozolc age, Cretaceous formations, and pre-Cretaceous basement rocks of the region from the Distrito Federal to the northern part of Guerrero. The late spring and summer of 1958 were devoted to preparing the final report at the University of Arizona and writIng the text as here presented.

\section{Acknowledgments}

The field work, map construction, laboratory studles, and preparation of the manuscript of the present report, as well as much of the collateral work by specialists; were carried out as a project of the Foreign Geology Branch of the United Stateg Geological Survey, whin a program of cooperation in geology with organizations of the Hexican government, largely for the purpose of cooperating in training liexican geology students and graduates and of giving support to Mexican geological organizations. Overall direction and financial support for this program has come from asencies of the United States Department of State, which, during the period of this study, consisted successively of 
the Technical Cooperation Administration, the Foreign Operations Administration, and the International Cooperation Administration. The writer was in charge of the geology program in Mexico, and the present study was carried on only as time could be spared from his major supervisory duties; consequently, most of the field work could be done only on weekends and during holiday periods. Collateral ald or support was given in different ways by the following Mexican organizations: National Institute for the Investigation of Mineral Resources, Institute of Geology of the National University, Exploration Department of Petróleos Mexicanos, and Executive Committee of the 20th International Geological Congress. The support of both United States and Mexican agencies and organizations is herewith gratefully acknowledged.

For continued overall support and encouragement throughout the period covered by this study, the writer is indebted mainly to W. D. Johnston, Jr., Chief of the Foreign Geology Branch of the U. S. Geological Survey. Colleagues of the Survey who were working in nearby areas under the same prosram and who contributed much by accompanying the writer into the field, discussing many mutual problems, and reviewing parts of the manuscript, were A. J. Bodenlos, $K$. Segerstrom, and B. W. Wilson; geologists in Mexico who contributed similarly, in one way or another, were mainly $\mathrm{z}$. de Cserna, who reviewed the entire manuscript, F. Bonet, 
W. E. Humphrey, S. H. Folk, E. Schmitter, O. BohnenbergerThomas, and F. Mooser. I. Jiménez-López of the National Institute for the Investigation of Mineral Resources kindly tied together a gap in photographic coverage between $\mathrm{Km}$. 134 and $\mathrm{Km}$. 138 of the Amacuzac-Taxco highway, by making a transit surxey. Preliminary petrographic work was done for the writer by E. Schmitter. Paleontologic identifications were made in Mexico by $F$. Bonet and his colleagues in the laboratories of Petróleos Mexicanos, an organization that also supported this study in different ways, and in the Institute of Geology by $G$. Alencáster de Cserna. Members of the Geological Survey who contributed particularly with studies of fauna were E. R. Applin, for microfauna, and R. W. Imlay for cephalopods and pelecypods. Others who contributed data on different groups of invertebrates, microfossils, and plants were C. Wythe Cooke, R. C. Douglass, A. R. Loeblich, Jr., R. Rezak, N. I. SohI, I. W. Stephenson, R. Todd, and J. W. Wells, the latter of Cornell University. Radiometric age determinations by the lead-alpha method were made by H. W. Jaffe and colleagues, of the Geological Survey, and welded tuffs were studied by C. S. Ross. J. I. Ramirez, of the Hexican Institute of Geophysics, aided very materially in map construction and compliation, and he also drafted most of the illustrations.

Various problems and principles relating to the present report were discussed profitably with members of the 
staff of the Geology Department of the University of Arizona, whose help is herewith acknowledged. In particular, E. B. Mayo, professor of structural geology in the Department of Geology, gave counsel in arrangement of the report and later reviewed the manuscript and proffered constructive criticism. Different chapters and/or aspects of the report were discussed with professors J. F. Lance and R. I. Dubois. Facilities for taking photomicrographs were extended by the Geology Department, and professor J. W. Anthony lent his camera for this work. This counsel and facilities of various kinds proffered by the University are herewith acknowledged with thanks.

Many others whose names are not specifically mentioned above, contributed in the field and in the office, and the writer wishes to express here his indebtedness to all these persons.

\section{PHYSIOGRAPEY}

Relation of area to Wexican physiographic provinces

Mexico has been divided into physlographic provinces by various authors, each one differing somewhat in setting boundaries and assigning names to the relatively distinct geomorphic units. The classification that is probably most generally used by geologists is that of ordóñez (1946), who takes into account geologic, as well as geomorphic features 
to a greater extent than do other authors. According to the divisions of Ordóñez, the area here described is along the north-central border of the Balsas Basin province. The northern border of the area corresponds to the boundary Iine between this province and the Southern Central Mesa province, which merges northward with the Northern Central liesa provInce and continues to the United States border into western Texas and southern New Mexico. The Balsas Basin province extends southward about $150 \mathrm{~km}$. to join the Southern sierra Madre province, which occupies the region from there to the Pacific Ocean.

Most other authors intercalate a narrow, irregular east-west belt between the Balsas Basin and the Central Mesa provinces, which has been called variously, Anáhuac Cordillera (Virlet-d'Aoust, 1866), Volcanic Axis (Galindo y Vi11a, 1946), Tarasco-Nahua System (Zepeda-Rincón, 1941), Neo-volcantc Cordillera (Robles-Ramos, 1942), Sierra of the Volcanoes (Garfias and Chapin, 1949, p. 83-97), and Neo-volcanic Zone (Williams, 1950, p. 167). This intercalated province consists of a belt of mainly Pleistocene basaltic volcanoes and lava flows, which crosses Mexico at about $19^{\circ}$ north latitude (see f1g. I and pl. 3-A). It lies between Mexico City and Cuernavaca at the longitude of the area mapped. In view of the distinctive geomorphic features of this belt, the writer feels that its separation from the other provinces is justified. Thus the strip north of a 
Ine between Cuernavaca and Cuautla forms the southern part of the Neo-volcanic Belt (see the oblique photographs in p1. 4 and 5), and the rest of the area mapped forms the northern border of the Balsas Basin province (see the obIlque photographs in pl. 6 and 7 ).

\section{Climate and regetation}

The climate of the area mapped is extremely variable from place to place and depends largely upon the altitude. Although the highest point in the state of Morelos Is PopocatépetI Volcano, with an altitude of $5452 \mathrm{~m}$. above sea level, this is an isolated peals just beyond the northeast corner of the map (see pl. 1 and 4). It has a permanent snow cap and annual precipitation of probably more than $2000 \mathrm{~mm}$. The range that forms the northern border of the map, from Popocatépetl to Cerro Zempoala, has an average altitude of about $2700 \mathrm{~m}$., with isolated peaks rising as high as $3300 \mathrm{~m}$. to $3900 \mathrm{~m}$. and rainfall of 1200 to 1400 mm. In this belt temperatures drop below freezing many nights in the months from October to February, but they rise to $10^{\circ} \mathrm{C}$. or higher during the day; in the summer months maximum dally temperatures seldom exceed $25^{\circ}$. C. The lowest point in the area mapped is about $730 \mathrm{~m}$. above sea level, at the city of Iguala in north-central Guerrero ( $p I$. $I$ and 6). Iinimum temperatures in the winter do not reach freezing and maximum temperatures in the summer rarely go 
as high as $38^{\circ} \mathrm{C}$., mean values for the coldest and warmest months being $24.5^{\circ}$ and $30.7^{\circ} \mathrm{C}$. Annual rainfall is about $1120 \mathrm{~mm}$. A better measure of the climate is indicated, perhaps, by mean data for Cuautla and Fuente de Ixtla, which are located in relatively large, thickly populated, bottomlands in central Morelos. At Cuautla, for example, the mean temperatures for the coldest and hottest months of the year are $19.2^{\circ}$ and $24.7^{\circ} \mathrm{C}$, respectively, and at Puente de Ixtla they are $20.4^{\circ}$ and $27.8^{\circ} \mathrm{C}$. Annual rainfall at Cuautla is only about $640 \mathrm{~mm}$, reflectins its position in a lowland area in the rain shadow of high Popocatépetl Volcano, but at Puente de Ixtla it is $940 \mathrm{~mm}$. Most of the rain falls in the region between June and september, and almost none falls in the months of January through March. Summer thunder storms may be severe and may cause considerable erosion damage to countryside and highways. Nost of the region, except the high mountainous part, may be described as having savanna to steppe climate.

The flora of the area mapped is even more varied than the climate. It has been described in some detail by Gándara and Muñoz-Lumbier (1935), whose work is here partly abstracted. Alpine flora generally characterizes the northern belt at altitudes above $2200 \mathrm{~m}$., where evergreen conifer forests predominate. Trees consist mainly of pines, spruce, cedar, hemlocks, juntper, aspen, and many species of oak, interspersed with patches of tall, tough grasses 
and ferns; underbrush is relatively sparse. At about the 19th parallel, alpine flora gives way in a short distance to tropical flora, and the two may be described as telescoped. Trees such as two species of madrone (ArctostaphyIos), peru or pirul (Schinus molle), tejocote (Grataegus mexicana), and capulin (Ardisia capoliina) become abundant in the forests as the conifers gradually drop out. Nine species of maguey (Agave) and many species of cactaceous plants become abundant as the trees thin out.

From the latitude and altitude of Cuernavaca (about $1550 \mathrm{m.}$ ) to the south flank of the Amacuzac River the vegetation is of frankly tropical character, although the Iong dry season accounts for rather sparse, open distribution and imparts a semi-arid aspect to the countryside; cactaceous plants and low grasses are common. Larger trees and shrubs consist dominantly of three species of huizache (Acacia), garambullo or fan palm (Brahea dulcig), ten species of amate (Ficus), three species of cazahuate (Ipomoca), two species of copal (Bursera), four species of colorin or pitos (Erythrina), huamúchil (P1thecollobium dulce), two species of tepehuaje (Lysiloma), pochote (Celba aesculifoIia), estropajo (Iuffa cylindrica), four species of cuajiote (Elaphrium), coyotomate (Vitex mollis), cuachalálate (Amphipterygnium adstringens), two species of palo santo (Gualacum), haba de San Ignacio (Hura polyandra), hormiguiilo (Cordia alliodora), three species of gua je (Leucaena), 
mezquite, three species of palo mulato (Zanthoxylon), two species of willow, tapincerán (wimosa), salvia, and jucca, besides a great variety of smaller shrubs and bushes, as well as flowering plants and grasses. This part of the area produces numerous fruits and other agricultural products, such as guayaba, chirimoya, nananche, mango, chico-zapote, mamey, grapefruit, orange, Iemon, Iime, banana, papaya, plum, anona, coconut, pineapple, coffee, sugar cane, rice, beans, sesame seed, peanut, Jícama, chile, tomato, cantaloupe, watermelon, corn, squashes and gourds, and truck vegetables.

The high area between the Amacuzac River and Iguala has vegetation similar to that at comparable altitudes north of Cuernavaca (1800-2000 m.), except that it has less admixture of the cooler-climate species. South of this highland, from Iguala southward to the Balsas River, the region is of frankly arid-tropical nature and vegetation is relatively sparse. Cactaceous plants become abundant and some areas are veritable forests of tree-like orgen cactus.

Vegetal cover is almost nowhere thick, and bedrock is exposed right at the surface over much of the Iimestone terrain. Soils are generally thin, except in bottom-land areas. Caliche (calcareous evaporite) pervades the upper 1 to $3 \mathrm{~m}$. of the soil, and it forms a much thicker blanket in certain places; it is generally more abundant and denser over limestone terrain than elsewhere. Thus the area is 
subject to relatively rapid erosion, except where caliche forms a hard pavement.

\section{Drainage \\ Modern arainage}

The northern edge of the map in plate 1 roughly marks the divide between the Mexico Basin of interior drainage, to the north, and the watershed of the Balsas or Fiexcala River, to the south (see fig. I). Most of the area mapped draing into the Amacuzac River, which has 1ts principal headwaters on the southern flanks of Nevado de Toluca or X1nantécatl Volcano, to the west, and from there eastward to Popocatépetl Volcano, on the southern flank of the Neo-volcanic Belt. South of Jojutla and Zacatepec (quad. G-6) the Amacuzac turns southward and becomes one of the principal tributaries of the Balsas River (fif. 1), which is the largest river in southern ifexico. The Amacuzac River is formed of two major tributaries, the Chontalcoatlán and San Jerónimo, which enter limestone tunnels as separate streams and emerge as a single river at Cacahuamilpa (quad. F-2 and I18. 1). The caverns at Cacahuamilpa are merely older, higher, abandoned underground courses of these two streams.

The southwestern part of the area mapped, roughly southwest of the Coxcatlán anticline (pl. 3-A), arains into the Iguala River, which flows south-southwestward into the 
Balsas River via a shorter route. Some of the drainage in the area is underground for considerable distances and eventually joins the surface waters through large springs, such as those at Las Estacas (quad. F-7) and Fundición. (south of Tehuixtla on the Amacuzac River; quad. H-5). The Balsas River flows westward and becomes the boundary Iine between the States of Guerrero and Hichoacán, and it eventually turns abruptly southward to empty into the Pacific Ocean ( $P I .3-B)$. The course of this river is in a sense anomalous, as it crosses the dominant northerly structural trend of the Cretaceous rocks, thus suggesting superposition from a Tertiary cover, although other factors such as Tertiary faultins and broad arching or warping also entered into its development.

\section{Pre-Pleistocene drainase}

Extrusion of the basaltic rocks that make up the Neo-volcanic Belt, here called the Chichinautzin basalt serles, had a profound effect upon the drainage system in most of the area mapped. The besalt blocked the southward exoreic drainage of the former liexico valley and produced the present endorelc basin. An attempt to show the pre-Pleistocene drainage. Iines has been made in plate 3-B. Apparently two major drainage lines extended southward from the old Yexico valley, one approximately under Cerro Chichinautzin and down the old eroded San Gaspar syncline to the Amacuzac 
River, and the other from a point $12 \mathrm{~km}$. west of Amecameca southward to Cuautla and down the Chinameca River valley. The paleo-drainage course via Cuautla was also suggested by Osorio-Tafall (1946, p. 148-149), but he attributed drainage blocking to extmusion of andesite in wiocene time, which is far too early, as will become apparent in later chapters of this report. The present valleys marking these old drainage courses are anomalously broad and are patently misfit to present drainage.

The pre-Pleistocene drainage Iines show converging at Iake Tequesquitenso were much like those at present, although the water volume was greater. The westernmost branch carried drainage from the Toluca valley via Ocullén, Malinalco, and Coatlán del RIo, before it was beheaded by basaltic extrusion in the Neo-volcanic Belt. The pre-Ple1stocene Amacuzac River seems to have had a course somewhat north of the present one, and its flow was surficial through a pass in the limestone mountains north of Cacahuamilpa, near where the San Jerónimo River now enters the Ilmestone tunnel (fig. 1). The Chontalcoatlán River probably jolned the San Jerónimo before going through the pass. The San Jerónimo headwater branch of the Amacuzac River was also beheaded by basaltic extmusion in the Neo-volcanic Belt. The present headwaters of the Lerma River east and southeast of Toluce (see fig. I) drained formerly into the San Jerónimo and Amacuzac Rivers. This beheading further reduced water 
volume in the lower Amacuaac valley. Pleistocene time has been one of general incision and some superposition of the channels of all the streams in the area mapped. Basaltic volcanism has repeatediy changed local drainage patterns and has interrupted incision in some places.

The former connection of the waters of the Balsas drainage with those of the Lerma River and the Mexico Basin is firther attested by the species of fishes now found in these different waters, as already pointed out by Alvarez (1949, p. 40). Alvarez states that lleek in 1904 gave evidence that the Lerma and Mexico Basin waters were connected in remote times (op. cit., p. 44). Meek cited the fish genera Girardinichthys and Lermichthys from present Mexico Basin and Lerma waters, respectively, as having a common ancestry. A species of Lermichthys found in the Zempoala Lakes is similar to a species of that genus in Lerma waters. The present writer believes that the Zempoala Lakes were separated from the Amacuzac-Balsas drainage in late Pleistocene time after separation of Hexico Basin waters from the Amacuzac drainage. In other words, at the beginning of Pleistocene time both the Iexico Basin and the Lerma headwaters were part of the Amacuzac-Balsas drainage basin.

\section{Land forms}

Wuch of the area between the Amacuzac River and the north edge of the map in plate 1 has extremely youthful, 
constructional or depositional topography, owing first to the inundation and burial of valleys and lowlands by great coalescing alluvial fans in late Pliocene and possibly early Pleistocene time (Cuernavaca formation) (see pl. 4 and 5), and second to volcanic eruptions and the extrusion of basaltic lava in Pleistocene and Recent time (Chichinautzin basalt series). The period of Pliocene alluviation resulted in burial of much of the older mature topography and in production of great alluvial plains dipping from $3^{\circ}$ to $5^{\circ}$ southward, in the north, to as low as $1^{0}$ to $2^{\circ}$ in the south. The higher hills and ridges of the mature topography rose as islands out of this sea of alluvium. All earlier drainage lines were obliterated and a new drainage system was established.

Erosion and dissection of the alluvial plains had progressed to some degree before volcanic eruptions became a dominating feature in the Neo-volcanic Belt. Eruptions and lava extrusion continued into historic time and produced most of the topography north of the latitude of Yautepec (quad. D-8). Basaltic lava flows inundated the valley east of Cuernavaca to as far south as the Amacuzac River, via Jojutla (quad. G-6), and thence down the river canyon almost to the point where the river leaves the map (quad. H-6). The valley followed by the Yautepec River was also inundated for some kilometers south of Yautepec, and the valley in which Cuautla is located was partly flooded by basalt. The 
result has been to produce broad, nearly flat floored lowlands, which have been further extended and flattened by alluviation from side valieys in late Pleistocene and Recent time. These flat areas provide the richest and most productive agricultural land in the region.

The northern border of the map consists of a very thick pile: ( 1500 to $2000 \mathrm{~m}$.) of basaltic lavas and breccias which is studded with the youngest, unburied scorla and cinder cones, of which more than 100 appear on the map in plate 3-B. Much of the outcrop area of the basaltic rocks lacks integrated drainage, except the flanks of the oldest cones and lava fields. Meanwhile, erosion continued to dissect the alluvial plains formed of the Cuernavaca formation, to a stage between early and late youth, in which deep, steep-sided canyons are separated by relatively undissected flats.

The hills and mountain ranges that were not buried by the Cuernavaca formation have mature topography, with almost no flat areas either on top or in valley bottoms. Those formed of Iimestone have a generally rounded aspect, but those formed of shale, volcanic rocks, or pre-Pliocene clastic rocks are more angular in appearance and are more Intricately dissected; the Tertiary volcanic piles tend to have cliffed slopes. All the area south of the Amacuzac River also is of this nature. The types of land forms mentioned are well illustrated in the oblique air photographs 
in plates 6 and 7 , which show the characterlstic appearance of the Balsas Basin physlographic province.

Wa jor valleys throughout the region have a general northerly to northwesterly trend, reflecting the dominant structures in the Cretaceous rocks. Most of them mark synclinal structures, but two conspicuous examples of valleys developed in anticlines are the one between Yautepec (quad. D-8) and Tlaltizapán (quad. F-7), which occupies the Tecumán-Tlaltizapán anticline, as well as the one south of Tlaquiltenango (quad. F-7). Belts of Tertiary rocks also tend to occupy synclinal structures in the underlying cretaceous rocks, which more often than not still retain some of the Mexcala formation (youngest Cretaceous unit) beneath the Tertiary volcanic and clastic units. This feature is characteristic also of terrain to the north, east, and south.

The development of karst feetures has been impressed upon the major land forms described above. These are part1cularly common in limestone terrain, but they extend out into areas of shale, volcanic rocks, and even poorly indurated Tertiary clastic rocks. Some of the largest features are the poljes developed in the Cuernavaca formation by dissolution of the underlying carbonate rocks. The best example is Lake Tequesquitenso (quad. G-5); others occupied by lakes are EI Rodeo (quad. $\dot{E}-5$ ), Coatetelco (quad. F-4), and Tuxpan (quad. J-2). Poljes not occupied by lakes are the aI- 
Iuvlated areas near Cuautlita (quad. F-4), west of Alpuyeca (quad. F-5), south of Xochitepec (quad. E-6), west and north of Puente de Ixtla (quad. G-5), and east of Tlaltizapán (quad. F-7). Four smaller features which might better be called sinks are located in the Tilzapotla rhyolite series about $2 \mathrm{~km}$. northeast of Tilzapotla (quad. I-5 and H-5). Small sinks are common in a.I the limestone terrain, notably in the areas of Iimestone outcrop between Cacahuamilpa (quad. E-3) and Iguala (quad. J-2). The poljes and sinks were formed after early Pleistocene time, considering the fact that they post-date the Cuernavaca formation, but some of them could, of course, have begun to form at an earIler date.

Dissolution of Iimestone has caused collapse of steep IImestone slopes in many places, as well as the formation of underground rivers, of which the most notable in the area are the Chontalcoatlán and San Jerónimo, which join to form the Amacuzac River at the Cacahuamilpa Caverns. Springs arising in the dolomite of the Morelos formation are common; the most notable are those at Fundición along the Amacuzac River (quad. H-5), with a flow of 3000 Iiters per minute, and those at Las Estacas (quad. F-7), which taken together have probably more than twice this flow. On the highest limestone uplands where rainfall is greatest, dissolution has produced areas of lapies or karren in which furrows generally do not exceed $1 \mathrm{~m}$. In depth, 
but they are exceptionally as deep as $3 \mathrm{~m}$. In: such areas, and particularly on hillsides which appear from a distance to be composed of bedrock devold of soll, locel farmers plant crops in the soll pockets dow in the furrows. This feature can be found in almost all the high limestone areas, but particularly in the range extending southward from Cerro Barriga de Plata (quad. D-7) to Monte Negro and Cerro Ectopan. Farther south it occurs notably in Cerro Temilpa (quad. F-8), Cerro Santa María (quad. G-7), Cerro Jojutla (quad. $[-7$ ), and the region mentioned above, between Cacahuamilpa and Iguala. The feature is important to the agricultural economy of the region, as most of the crops in the steep highland areas are planted in limestone karren and sinks.

\section{SEDIMENTARY, VOLCANIC, AND IETAMORPHIC ROCKS General features}

Before the present study was begun in 1950, rocks in this part of Mexico and for some distance to the south; east, west, and north, had generally been described only as blostratigraphic or chronostratigraphic units, without an attempt to define and map Iithostratigraphic units or true formations in the stratigraphic sense. As a result, considerable confusion in thinking has arisen and will continue to arise for some time to come. The excellent ploneer work of Burckhardt (1919) in establishing and describing bio- 
stratisraphic units in the Zumpango del Rio area of central Guerrero (fig. I), is a case in point. Guzmán (1950) grouped the biostratigraphic units into chronostratigraphic units which he referred to the standard systems and series, although he cited formation names proposed earlier in caxaca, Puebla, and easternmost Guerrero by himself and others. The present work initiated an attempt by the writer and others to divide the rocks of the region into true Iithostratigraphic units of formational and group rank and to name the units thus chosen. The reader will therefore note that almost no formation names existed in this region prior to the present work and that the nearest named rocks are to the east.

The names, ages, and relationships of the stratified rocks in the area studied are summarized in columns $I$ and 2 of the stratigraphic correlation table in fisure 2. Colunns representing five other areas to the south, west, north, and southeast of viorelos are given in the same table, for comparison, as well as standard European stage names for the Jurassic and Cretaceous systems, and Texas stage names for the Cretaceous system. The names assigned to all the formational units cited, except the Acahuizotia formation, were proposed formally by the writer in the guidebook for Excursion C-9 of the 20th International Geological Congress in Hexico (Fries, 1956c). Publication of this guldebook was delayed until late 1958, but the names appeared earlier in the 


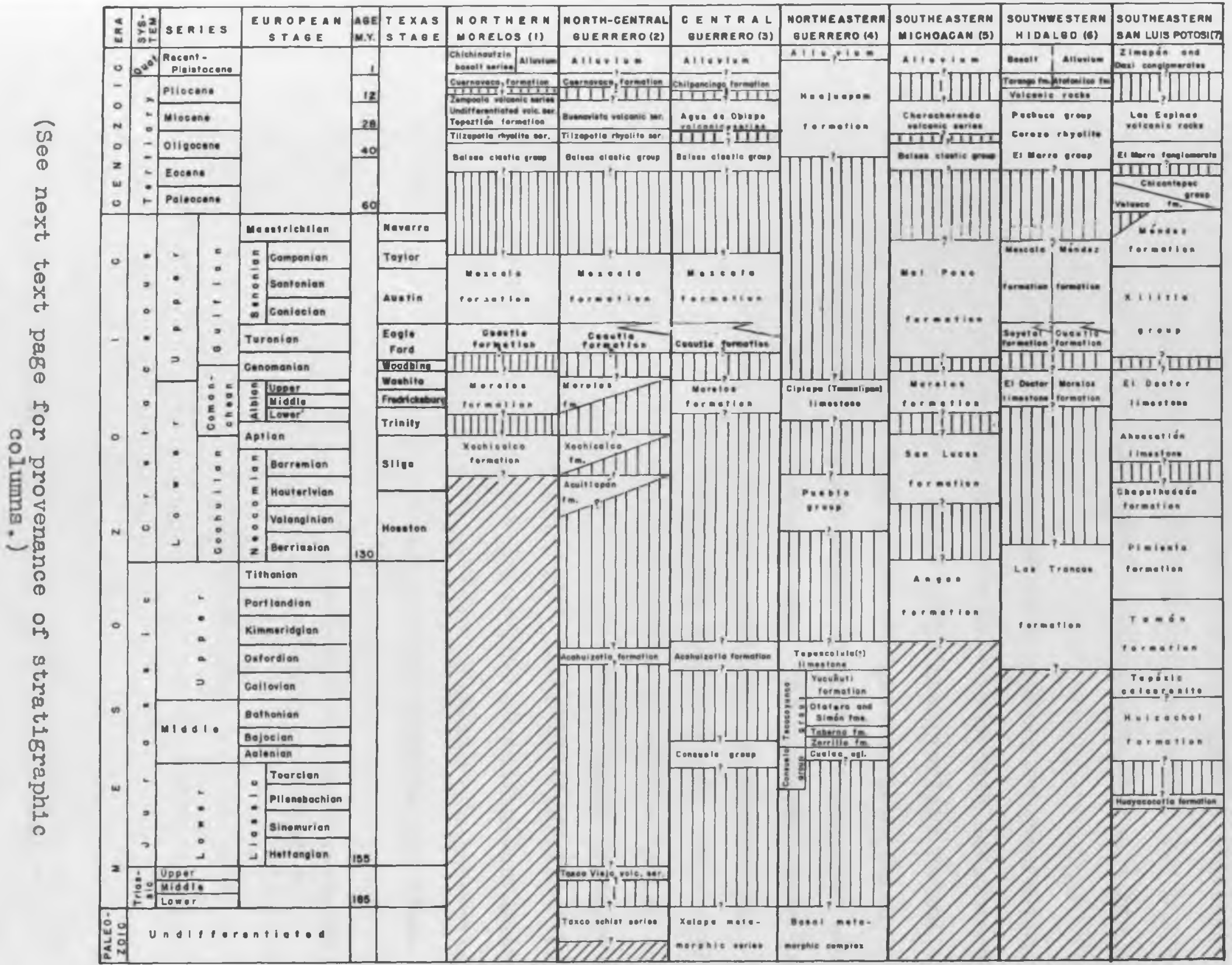


guidebook for Excursions A-4 and C-2 published by the Congress in 1956, and in the guidebook for Excursions A-9 and C-12 published by the Asociación Mexicana de Geólogos Petroleros in 1957.

The oldest rocks in the area studied are sericitic and chlorltic schists of probable late Paleozolic age, named the Taxco schist series. These rocks are overlain unconformably by the Taxco Viejo green volcanic series, which consists of slightly metamorphosed chloritic greenstone and is of possible Late Triassic(?) age. Unconformably over the greenstone are remnants of the fcahuizotla slate and calcareous phyllite, of probable Late Jurassic age. This unit is overlain with presumed unconformity by the Acuitlapán phyllitic shale, judged to be of Neocomian (Early Cretaceous) age, which is in turn overlain with probable disconformity, in places, by the Xochicalco Iimestone, of Aptian-Barremian ege. Overlying this unit, also with probable disconformity, is the Worelos formation of interbedded dolomite and Iime-

PROVENANCE OF STRATIGRAPHIC COLUIITS IN FIGURE 2
(I) This report, north-central Horelos.
(2) This report, Taxco-Buenavista region.
(3) Fries, Carl Jr., 1956b, fis. 2.
(4) Erben, H. K., 1956 , fig. 14.
(5) Pantoja-Alor, Jerjes, 1957, pl. 3.
(6) Segerstrom, Kenneth, in press.
(7) Bodenlos, A. J., 1956, table 9.

Note: Age is given in millions of years, accorains to the time scale given in Report of the ivational Research Council, Committee on Neasurement of Geologic Time, 1949-50. 
stone, which is of Albian to early Cenomanian age. A disconformity on the iorelos formation is covered by the CuautIa Iimestone, of Turonian age, and the latter unit is overlain by the liexcala formation of interbedded calcareous subEraywacke, siltstone, and. shale, with thin basal limestone beds locally, whose age is Conlacian at the base. The age of the top of the fexcala formation, which is deeply eroded, is not know, but no evidence is avallable of an age more recent than Santonian or Campanian.

A great period of folding and erosion occurred before the Balsas clastic Group, of probable late Eocene and early Olisocene ase, was deposited unconformably on all the earlier formations down to the schist. This was followed in later Oligocene to early Pliocene time by deposition of the Tilzapotla rhyolite series, the Tepoztlán formation, and the Buenavista, Unidfferentiated, and Zemporla volcanic serles, with minor disconformities within them. The next unit to be laid down was the Cuernavaca formation, with great erosional unconformity, in late Pliocene and possibly into early Pleistocene time. The Chichinautzin basalt seriës was extruded and deposited with erosional unconformity in Pleistocene time on the Cuernavaca formation and older rocks. Basaltic volcanism has continued into modern time, together with alluviation in places where these volcanic rocks were not deposited. 
Taxco schist series

Distribution and physiographic expression

The Taxco schist (Fries, 1956c) was named for its outcrop area to the east and southeast of the city of Taxco (quad. $\mathrm{H}-1$ ), where it has been uncovered by erosion in an area about $4 \mathrm{sq}$. $\mathrm{km}$. In extent. It appears also just east of Taxco Viejo (quad. I'-I) in an area nearly as large as that at Taxco. The two outcrop areas together mark what was a topographically high belt in Albian time and appear, from the pattern of Lower Cretaceous stratigraphy, to represent the southeastern prolongation of a peninsula extending from a larger landmass lying to the northwest. The $u$ nit is the oldest one in the area mapped and forms the basement on which all others were deposited, with more or less angular unconformity. It was not mapped or studied in deta1l, and no attempt was made to separate from it erosion remnants of the overlying Taxco Viejo green volcanic series, Acahuizotla formation, and Acuitlapán formation, which are present from place to place in the outcrop areas of the schist.

The Taxco schist is a relatively easily eroded rock and, where the overlying resistant limestone has been stripped away, tends to form moderately dissected low terrain (see pl. 7). The unit is more dissected than the Morelos Iimestone but is considerably less intricately furrowed than 
the softer Mexcala formation, as show by inspection of plate 7. Slopes are steep and generally smooth, belng cliffed only where oversteepening has been caused by late Pleistocene rapid valiey incision.

\section{Petrography and thickness}

Only two specimens collected from the Taxco schist were studied in thin section. One of these (F-71-54), from a road cut at $\mathrm{Km}$. 160.5 at the east edge of Taxco, consists of a medium-gray, crenulated sericite schist, made up of quartz, feldspar, and grains composed of microcrystalline asgregates of quartz, feldspar, and sericite, all set in a denser sericitic matrix (pl. 8-c). ${ }^{*}$. The original rock is interpreted as having been a rhyolitic tuff. The . second sample. (F57-58) was collected from $600 \mathrm{~m}$. north-northeast of Taxco Viejo. It is a very fine grained, light-gray sericite schist, which also appears to have originally been a rhyolitic tuff ( $\mathrm{pl}, 8-\mathrm{D}$ and pl. 9-A).

$\because$

Detailed description of the Iithology and faunal content of samples collected in the area mapped are given in the section on Provenance, petrographic description, and faunal content of rock samples cited in the text. A summary list of samples collected from the rock formations and referred to in the text is given also in the appendix, after the $a b-$ ove descriptions. 
Fowler and others (1948, p. 5) group the sericite schist with black slate and arkosic sandstone, which, because of unconformable relationships, the present writer has separated out and referred to the Acahulzotla and Acuitlapán formations. Osborne (1956, p. 80) describes the unit as including many varieties of distorted and crenulated chloritic and sericitic schist, as well as angular conglomerate, graywacke, and other clastic rocks. The latter rock types mentioned by osborne may likewise actually belong to formations which the writer considers to be younger than the schist.

The base of the Taxco schtst is not exposed in the area mapped. The upper surface is erosional and is usually covered by a conglomerate composed of eroded schist debris, on top of which may be present any one of the younger formations up to the Balsas clastic group, owing to tectonic movements and erosion at several times before the latter group was deposited. The total thickness of schist exposed is at least $300 \mathrm{~m}$. but may be greater because of probable truncation across folded beds.

\section{Metamorphism and origin}

The grade of metamorphism exhibited by the schist 1s low, as indicated by the presence of chlorite, sericite, and epldote (in some places), without development of garnot or other typical metamorphic minerals. The mineral assemb- 
lage suggests that the rock was produced by regional dynamic metamorphism at moderately low temperatures. The original rocks probably consisted dominantly of a sequence of tuffs, brecclas, and possibly flows of rhyolitic composition, with minor interbedded clastic layers.

Foliation in the schist has a general westerly trend and dips are northerly and southerly at relatively low angles, less than $30^{\circ}$. This suggests that the formation was probably tightly folded and that overturning is present, although detalled work to prove this point is lacking. Later compression, particularly after deposition of the Cretaceous formations, impressed the marked crenulation shown in most outcrops of the schist. Calcite and quartz veinlets are abundant, and the major ore deposits of the region are partly in this formation. Basic dikes of andesite or diabase( ( ) are numerous and were apparently intruded and eroded before the next overlying formation was laid down.

\section{Age and correlation}

The age of the Taxco schist has not yet been confirmed by radiometric determination, but because the schist is considerably more metamorphosed than the oldest of the overlying formations, which is the Taxco Viejo green volcan1c series of Late Triassic(?) age, it is very probably older than Mesozoic. Horeover, the relatively lower grade of metamorphism as compared with that of schists and gneisses 
that crop out in large regions to the east in the states of Puebla and Oaxaca, in part called the Acatlán schists (Salas, 1949, p. 82-85; Calderón-García, 1956, p. 12; Erben, 1956 , p. 13), and of the Xolapa metamorphic series (Fries, 1956b, p. 292), suggests that the Taxco schist belongs to the upper part of the basal complex and may be of late Paleozolc age. Large areas of simliar. low-grade schist crop out to the northwest of Taxco in the Zacualpan region, and to the west and southwest of Taxco on the north side of the Balsas Basin.

\section{Taxco Viejo green volcanic series}

\section{Distribution}

The Taxco Viejo green volcanic series (Fries, 1956c) crops out on the hillslope directly east of the town of Taxco Viejo (quad. I-I) but has not been mapped separately from outcrops of the Taxco schlst. Remnants of the formation probably occur also in the area of schist near Taxco, which was not traversed in detall by the writer. Physiographic expression of the formation is much like that of the Taxco schist and is characterized by relatively low, moderately well dissected terrain (pl. 7).

\section{Lithology, thickness, and origin}

The Taxco Viejo greenstone consists mainly of interbedded andesitic tuff, breccia, and minor lava flows; 
the clastic beds are cemented largely by calcite. Only one specimen (F-67-54) of the rock was examined in thin section (pI. 8-A and -B). The dominant color is greenish, but some patches in the formation are purplish. Pyrite and epidote are common in some parts of the outcrop area. Many fragments that make up the rock are compressed and elonsated, undoubtedly as a result of regional dynamic metamorphism, during which large quantities of chlorite were formed and the rock took on a moderately well foliated appearance, particularly in the finest-grained beds. The thickness of the unit is at least $100 \mathrm{~m}$. and may originally have been many times that great.

The unit rests unconformably on the Taxco schist and In places has a basal conglomerate made up of schist fragments. Its extent in the area mapped is so limited that not much can be said of its mode of accumulation. The abundance of calcite in the matrix of the tuff and breccia beds, however, suggests that the unit may have been deposited largely in marine waters, although break-down of the plag10clases and propylitization may have resulted in deposition of calcite. Later tectonic movements and erosion resulted in removal of much of the formation before younger rock $u$ nits were deposited, and different units up to the Balsas clastic group overlie it. 


\section{Age and correlation}

No fossils have been found to date in the Taxco Viejo greenstone, and its age can therefore be deduced only from relationships with overlying and underlying rocks and by long-distance correlation. The unit overlies the Taxco schist with angular unconformity and is overlain unconformably by the Acahuizotla formation, which is considered to be of Late Jurassic age (de Cserna in Fries, 1956b, p. 295).

The nearest region in which greenstone of apparently similar stratigraphic relationships has been dated on fossil evidence is Zacatecas, in central liexico (see pl. 3-B). There, Burckhardt (1906, p. 44) found Late Triassic marine fossils in black slaty rocks interbedded with volcanic greenstone (see also Maldonado-Koerdell, 1948, p. 300). In later studies Burckhardt correlated these rocks with greenstone in the Guanajuato mining district farther south (1930, p. 5-6). The present writer has seen large areas of similar greenstone west of Teloloapan, Guerrero, only $35 \mathrm{~km}$. southwest of Taxco (fig. I), as well as in the drainage basin of the Chontalcoatlán River only 20 to $30 \mathrm{~km}$. north and northwest of Taxco. Rocks that he considers to belong to the same unit crop out intermittently westward from Taxco in the States of Michoacán, Colima, and Jalisco (pl. 3-B). In southwestern Puebla and northwestern Oaxaca, to the east and southeast of Taxco, the first rocks resting on the basal 
metamorphic complex are continental clastic sediments with Interbedded carbonaceous shale, whlch may be of latest Tr1assic age at the base, but are mainly of Early to Middle Jurass1c age (Calderón-Garcla, 1956, p. 13-15; Erben, 1956, p. 14-15). The greenstone series was presumably not depos1ted there or was eroded before the continental clast1c sediments began to accumulate.

Acahuizotla formation

Distribution and 11thology

The Acahulzotla formation was named by de Cserna (1n Fries, 1956b, p. 294-295) for outcrops at Acahuizotla near $\mathrm{Km} .300$ of the Acapulco highway (11g. 1). The un1t there consists of brown-weathering, interbedded argillaceous limestone and calcareous siltstone. It has poor resistance to erosion and tends to form moderately dissected, low terrain. In the Taxco region the writer has referred to the Acahuizotla formation small remnants of brownweathering argillaceous limestone and carbonaceous siltstone with undulating bedding planes and pronounced follation, because of their unconformable position between the Taxco schist or the Taxco Viejo greenstone and the Acultlapán or younger Cretaceous formations. The total thickness of the unit 18 not known, and only a few tens of meters remain in the localities where this rock is exposed. 
The distribution of the Acahuizotla unit in the Taxco region was not determined in detail, and the unit was not mapped separately from the Taxco schist. Beds considered to belong to it were 1dentified in the canyon upstream from Pichahua, about $1.5 \mathrm{~km}$. southeast of $\mathrm{Km} .16 \mathrm{I}$ of the Taxco highway (quad. H-I). At this locality the rock consists of follated, interbedded, dark-gray to black argillaceous limestone and carbonaceous shale, which lie unconformably on the Taxco schist and have a basal conglomerate from $I$ to $2 \mathrm{~m}$. thick composed of schist fragments. The follation was also Impressed upon the conglomerate with its earlier-formed and eroded schist fragments. The Taxco Viejo greenstone is notably absent, a feature interpreted as due to erosion of this unit before deposition of the Acahuizotla beds.

A second locality in which a small remnant of the Acahuizotla unit was recognized is the rock face just above the tallings dump of the Pedregal mine, below the highway near $\mathrm{Km}$. 160 at the north entrance to Taxco (quad. H-I). The rock is thin-bedded, calcareous, well follated, and has undulating bedding planes. It overlies the Taxco schist directly, and 1t is overlain unconformably by the Morelos formation, of late Early Cretaceous age. A third locality in which beds referred to the Acahulzotla formation were seen is a ridge about $1.5 \mathrm{~km}$. east of Taxco Viejo (quad. I-I), where the unit rests upon the Taxco Viejo greenstone and is overlain by the Morelos formation. More extensive outcrops 
occur from 1 to $3 \mathrm{~km}$. southeast of Taxco Viejo, near the contact between the area of old rocks and the Morelos formation. Characteristic features in these latter two 10calities are the undulating bedding and strong foliation of the argillaceous Iimestone or calcareous siltstone referred to the Acahuizotla formation.

\section{Age and correlation}

The age of the rocks referred to the Acahuizotla formation in the Taxco region has not been determined on fossil evidence. Samples collected for microfaunal study in thin section were either devold of fauna or too strongly sheared to permit recognition of microfossils. The age has therefore been assigned to the unit on the basis of correlation wlth unlts in northeastern Guerrero and northwestern Oaxaca, where the presumed equivalents are called the Teposcolula Iimestone (Salas, 1949, p. 105-108) or Cidaris Iimestone (Burckhardt, 1930, p. 98-99), of Oxfordian (Late Jurass1c) age (Erben, 1956, p. 22-24). The unit is also correlated with rocks in western H1dalgo, north of the area mapped (fig. 1), which have been called the Las Trancas formation (Segerstrom, 1956, p. 12) and which are of Late Jurassic age. The latter formation is more nearly like the Acahuizotla formation in lithology than elther the Teposcolula or Cidaris Iimestones. The Acahuizotla formation may be correlated with the lower part of the Angao formation 
described by Pantoja-Alor (1957, p. 17-19) in the Huetamo area about $100 \mathrm{~km}$. west of Taxco (locality 5 in pl. 3-A). This latter formation also consists of marine clastic and calcareous rocks of Late Jurassic age.

\section{Acuitlapán formation}

\section{Distribution; 11thology, and thickness}

The name Acuitlapán formation (Fries, 1956c) was taken from the town of Acultlapan at $\mathrm{Km}$. 144.5 of the Amacuzac-Taxco highway (quad. G-2). The formation crops out along the southwest base of the high limestone ridge, lnown as Cerro Acuitlapán, to the northeast of the town. A remnant of the unit rests on the Taxco schist near the Taxco cemetery, about $1 \mathrm{~km}$. southeast of the center of the city (quad. $\mathrm{H}-1$ ). The areas of outcrop are too small to have well defined physiographic expression, but they are at least topographically low and dissected. Iarge areas of the formation would undoubtedly form low, closely furrowed terrain.

The unit consists of a series of thin argillaceous and silty beds. with some calcareous interbeds; all largely recrystallized to slaty phylite. The color of fresh rock is medium- to dark-gray, but some beds are nearly black and may be somewhat carbonaceous. Bedding planes are rather uniform, in contrast to the undulating planes in the Acahuizotla formation. 
The original full thickness can not be determined in the area mapped because of close folding and incomplete exposure of the formation. A partial thickmess of $120 \mathrm{~m}$. is exposed in the type locality, but faults hide the base of the unit there and prevent measuring the total thickness.

Stratigraphic relationships, age, and correlation

The Acultlapán formation rests unconformably upon older formations down to the Taxco schist. It is overlein by the Xochicalco and Morelos formations with discordance, congidering the presence of the Xochicalco formation between the two in the type locality and its absence near the Taxco cemetery.

Fossils were not found in the unit, and its age is therefore deduced from its stratigraphic position. The overlying Xochicalco formation contains microfauna of AptianBarremian age, and the next older formation is judged to be of probable Late Jurassic age. The Acuiltlapán formation is thus thought to be of Neocomian (early Early Cretaceous) age.

The unit may be correlated with partly continental and partly marine clastic rocks in northeastern Guerrero (locality 4 in pl. 3-A), described by Guzmán (1950, p. 120) and Erben (1956a, p. 25-26), respectively, and referred to the Puebla group by Erben. It may also be correlated with the lower part of the San Lucas formation (Pantoja-Alor, 
1957, p. 19-25) in southeastern Michoacán (Iocal1ty 5 in pl. 3-A), which consists of interbedded marine shale, siltstone, sandstone, conglomerate, and some limestone. Hall (1903, p. 333-334) had referred to some of these rocks as "Olive slate" and had placed them in the Necoxtla group, of Neocomian age. Outcrops of marine clastic rocks of probable Neocomian age have been seen by the writer also in the region between locality 5 of plate 3-A and the Acuitlapán 10cality. Rocks similar to the Acuitlapán formation occur near Zacualpan and Ixtapan de la Sal in the Chontalcoatlán drainage basin only 20 to $30 \mathrm{~km}$. northwest of Acuitlapán. Rocks of Neocomian age are apparently absent north of Mexico City, except in northern Hidalgo, where they consist of a Iimestone facies (Bodenlos, 1956, p. 301).

\section{Xochicalco formation}

Distribution and physiographic expression

The Xochicalco formation (Fries, 1956c) was named after the archaeological site and hill of that name near the west end of section Iine $D-D^{\prime}$ (quad. E-5). This thin-bedded Iimestone unit crops out from there eastward to Cerro Colotepec, where it is intruded by a granitic stock, and southward almost to the Alpuyeca-Cacahuamilpa highway, in an area about $9 \mathrm{sq}$. $\mathrm{km}$. in extent. The northwestern flank of Cerro Xochicalco is made up of Iimestone of the overlying Morelos formation, but the exact contact was not traced in deta1I, 
because the area was covered only by distant oblique photographs which did not show the back hillsides nor permit the speed of mapping required for this project (see pI. 4).

A second area in which the Xochicalco limestone is exposed is along the southwest base of Cerro Acultlapán (quad. G-2), where it lies on Acuitlapán slaty phyllite and is overlain by Morelos Iimestone and dolomite. The unit was not recognized in the areas of old rock at Taxco and Taxco Viejo, but remnants of it may be present under the Morelos formation along the northeast contact of the outcrop of old rock east of Taxco Viejo. A large outcrop of the unit occurs around the granitic and diabasic stocks west of Buenavista de Cuéllar (quad. I-3). The underlying formation is not exposed, and the overlying formation is Morelos limestone and dolomite. A small outcrop crosses the Amacuzac-Iguala toll road just south of $\mathrm{Km} .157$ (quad. J-3). Other outcrops appear east and southeast of there, on the northeastern, eastern, and southeastern flanks of Cerro Tuxpan, where intrusive granitic rocks are also present. All the areas mentioned are anticlinal. Topography developed on the Xochicalco Iimestone is not quite as rounded as that on the Morelos formation, and drainage channels are more closely spaced. The flanks of Cerro Tuxpan shown in the oblique photographin plate 7 illustrate the physiographic expression of the formation. The Cerro Xochicalco-Cerro Colotepec area has similar topography. 
Slopes tend to be steep and expose bedrock, but cliffs are not common. Probably the areas of schist, though somewhat less resistant, are more nearly like the Xochicalco unit in physiographic expression than any of the other rock units in the area mapped.

\section{Lithology and thickness}

The Xochicalco formation consists of a séquence of very thin to medium-thick, dense Iimestone beds with generally uniform bedding planes. The color ranges from dark gray to black, depending upon the carbonaceous content, which is probably as high as several per cent in some beds. A characteristic of at least the upper part of the formation is an abundance of chert interleaves, to the extent of forming nearly half the rock in some places. The finest interleaves are only 1 to $2 \mathrm{~mm}$. thick, but others range up to 10 or $15 \mathrm{~mm}$. across. Individual chert interleaves and lenses are tabular and do not continue laterally for more than a few meters. The thinner beds of Iimestone are characteristically finely laminated, the grain size ranging from calcilutite to calcigiltite and even fine-grained calcarenite. Other, less noticeably laminated beds consist of pelleted or clotted cryptocrystaline calcite with admixture of carbonaceous matter and with a calcilutite matrix. Rhombohedrons of dolomite are common but form only a few per cent of the rock in the specimens that were examined in thin 
section. At lower horizons in the formation, the thin beds seem to become less numerous and medium-thick beds predomInate; chert becomes less abundant, also.

Thickness estimates are difficult to make, except in the area northeast of Acuitlapán, because the formation is repeated by tight folding and the base is not exposed. In the Acuitlapán outcrop area, where both top and bottom of the formation are exposed, the thickness is about $150 \mathrm{~m}$. In that locality a sequence of perhaps 10 to $15 \mathrm{~m}$ : of slightIf phyllitic shale beds occurs some 30 or $40 \mathrm{~m}$. above the base of the formation and is included in it. In the type locality of the formation, between Cerro Colotepec and Cerro Xochlcalco, the base is not exposed and the minimum thickness seems to exceed $500 \mathrm{~m}$., but reliable estimates are difficult or impossible to make because of repetition due to close folding. The formation was not studied with sufficlent detail to establish horizon markers.

Stratigraphic relationships and metamorphism

The Xochicalco formation is overlain by different horizons of the Morelos formation. Beds on both sides of the contact seem to be parallel in individual outcrops. The top of the lower formation must have been eroded, however, before the upper one was deposited, for the reason cited above and because the Iithology of the lower formation at the contact varies considerably from place to place, susgesting 
removal of beds. At the contact just north of Puente Quebrado (quad. G-5) some $30 \mathrm{~m}$. of thin argillaceous beds are present at the top of the Xochicalco formation, whereas elsewhere they are absent and different types of Iimestone appear in their place. The unit is missing completely in the Taxco district, owing either to erosion or non-deposition, and it certainiy thickens away from the old land masses near Taxco and Taxco V1ejo. The lower contact is known only northeast of Acuitlapán, where the unit is underlain by the Acuitlapán formation with apparent angular concordance.

Folding has affected the Xochicalco formation to a much greater degree than it has the overlying Morelos formation, and the relationship may be described as disharmon1c. This does not mean that the Xochicalco formation was folded before the Morelos formation was deposited, although some warping may have taken place. The thin-bedded, argillaceous or carbonaceous character of the Xochicalco. Iimestone made the beds more susceptible to folding than the overlying thick Iimestone beds. Degree of deformation is more nearly comparable to that of the underlying, relatively incompetent, Acuitlapán slaty phyli1te.

Penecontemporaneous dolomitization was generally weak, and although dolomite rhombohedrons were seen in thin section, no strongly dolomitized beds were recognized in the field. Tectonic movements caused intricate shattering of much of the Xochicalco Iimestone, and fractures were healed 
by deposition of white calcite. Fine shearing apparent in thin section caused distortion or destruction of much of the microfauna. Recrystallization and local marmorization occurred in beds near intrusive bodies, with concomitant lightening in color of the rock.

Fossils, ase, and correlation

No macrofossils were seen in outcrops of the Xochicalco formation, but numerous chips were taken for microfaunal study in thin section. All the samples collected were examined by $F$. Bonet in the paleontological laboratorles of Petróleos Wexicanos. Only six samples out of more than a dozen collected from different localities contained identifiable microfauna (sample numbers are given at the end of the appendix, and samples are described in the first part of the appendix). The fauna reported is as follows:

Colomiella mexicana Bonet (1956, p. 42-45, p. 19-20) Rusoglobigerina sp. Silicified radiolaria Calcified radiolaria Unidentifiable microfossils

Bonet considers Colomiella mexicana to have appeared at the beginning of late Barremian time and to have ranged through Aptian time (1956, p. II, table 2). The fossil assemblage indicates deposition in quiet, relatively deep water in which benthonic fauna was absent. The age of the top of the Xochicalco formation is therefore probably no younger than Aptian. The lowermost samples collected contained the 
same fauna and are thus no older than late Barremian, but the base of the formation where it is thickest was not seen nor sampled and may be somewhat older.

Rocks of Aptian-Barremian age pinch out southward between the area mapped and central Guerrero, but they are present In the Balsas Basin to the west, where they appear in a clastic facies called the San Lucas formation (PantojaAlor, 1957, p. 19-25), which seems to be equivalent in age to both the Xochicalco and Acultlapán formations combined. Eastward, in eastern Puebla (pl. 3-A), rocks of Barremian age consist of interbedded calcareous shale and argillaceous Iimestone with purer limestone lenses, called the Zapotitlán formation (Calderón-Garcla, 1956, p. 16-17), which is in turn overlain by lower Aptian rocks consisting of calcareous shale with thin interbeds of calcareous sandstone and small lenses of oyster coquina, called the San Juan Raya formation (op. cit., p. 18-19). The latter formation apparently changes in facies to the north-northeast and becomes an alternating series of limestone and black chert beds, which contain Iess chert upward and become more argillaceous. These rocks are called the Mitahuatepec formation and are judged to be of Aptian age (op. cit., p. 19-20). The latter formation is more nearly like the Xochicalco formation in Iithology than all the other formations mentioned. Rocks of Aptian-Barremian age pinch out northward from the area mapped and reappear again only north of Jacala 
In northern Hidalso (pI. 3-A), where they consist of darkgray dense limestone with chert lenses and nodules, separated by occasional, thin, black and green shale interbeds, named the Ahuacatlán formation (Bodenlos, 1956, p. 301 ). Macrofauna is rare and microfauna is nearly identical with that of the Xochicalco formation, which is, moreover, similar in Iithology.

\section{Morelos formation}

Distribution and physiographic expresgion

The name Morelos formation was proposed (Fries, 1956c) for the thick (up to $900 \mathrm{~m}$.) Iimestone and dolomite unit of Cenomanian-Albian (late Early Cretaceous) age that crops out in the state of Korelos and adjoining States of México and Guerrero. The northernmost outcrop in the area mapped is about $2.5 \mathrm{~km}$. south of Tepoztlán (quad. C-7), where the formation disappears under the overlying Tepoztlán foruation, of Oligocene(?) age, and does not reappear from under the Tertiary cover until the latitude of Tequisquiac-Apaxco, $110 \mathrm{~km}$. to the north, or about $60 \mathrm{~km}$. north of Hexico City (fig. I). The formation continues eastward into the States of Puebla and Oaxaca, where other names have been proposed, and southward to $\mathrm{Km}$. 350 of the Acapulco highway (f1g. 1), where it appears to pinch out. Taxco marks the western ilmit of the formation in the area mapped, and from there the boundary line of the old shore apparently 
extends due north for more than $150 \mathrm{~km}$., as well as nearly due west into the States of México and Michoacán for an undetermined distance. The area of outcrop of this formation in plate $I$ is nearly as extensive as that of any other single unit.

The thick beds of Iimestone and dolomite of the Norelos formation are highly resistant to erosion under the climatic conditions prevailing in the region, and they tend to form topographic highs, except where the overlying, thick Tertiary volcanic cover has not been stripped away. The best example of the physiographic expression of the formation is the area shown in the right foreground of the obIique photograph in plate 6 , and in the left foreground in plate 7 . Upland slopes are rounded and convex upward. Drainage lines are rather widely spaced, and valley sides become steeper downward, terminating in narrow $V$-shaped bottoms with little alluvium. Small sinks are common, particularly along some of the upland valleys, and cliffs are present wherever slopes are steep. Dissolution of the Iimestone and calcitic cement of the dolomite has caused collapse of some hillsides, with the further development of cliffs. The topographic aspect of terrain in which the Norelos formation crops out is one of the most distinctive in the region and is approached only by the overlying Cuautla formation and the thick-bedded, well indurated limestone conglomerate of the Balsas clastic group, but 
sinks are less common in these latter two formations.

\section{Ifthology of the carbonate member}

The Morelos formation consists dominently of a sequence of interbedded Iimestone and dolomite beds with varying quantities of chert in nodules, lenses, and irregular silicified grains and fossil fragments. The basal part of the formation consists of an anhydrite member in the eastern part of the area mapped. Admixture of argillaceous material is generally minor, and shale interbeds were not observed anywhere in the region. A series of nine samples selected in the field for showing minimum and maximum dolomitization gave a range of from 2.3 to 83.3 per cent dolomite (sample F-65-54) in determinations by E. Schmitter of the Mexican Institute of Geology, and insoluble residues in these samples varied from 0.3 to 4.0 per cent. The proportion of carbonate in the beds is probably generally over 98 per cent, if the chert-derived silica is discounted, indicating a relatively pure carbonate rock. The sequence of Iithologic types in a given section appears to change in detail. Within relatively short distances, so that no attempt was made to establish a single "type" locality.

The color of the Morelos formation varies markedly from bed to bed, rangins from light creamy gray to black. The dark beds are generally much more fetid when freshly broken than the light beds and contain bituminous matter in 
variable quantity. Dolomitized beds have a brownish cast added, varying from light brownish gray to brownish black; some of them are mottled. Beds in the formation are generally thick, ransins mainly between 20 and $60 \mathrm{~cm}$. in thickness.

The texture of the Iimestone ranges from calcllutite to calcirudite, but the most common textural type is calcarenite. The grains that make up the limestone consist mainly of agglutinated pellets or clots of cryptocrystaline calcite, foraminiferal tests, and fragmented and abraded biogenic matter. Some interbeds consist of biostromes of rudistids (aberrant forms of pelecypods), gastropods, and oysters, embedded in a calcilutite to calcarenite matrix. Textures of specimens from different localities and horizons in the formation are lliustrated in plates 10-12 and plate 13-A and $-B$, which are photographs of acetate peels made from etched polished sections and enlarged to a maximum of five times.

No limestone beds of truly clastic origin--1. e., limestone composed of detrital grains derived from subaerial erosion of a limestone-dolomite terrain--were recosnized in the Horelos formation in the area mapped. In other words, the formation is thought to represent the accumulation of lime particles by precipitation essentially in place, accompanied and followed by agelutination, re-working, and re-distribution of the Grains with almost no admixture of 
terrigenous material. The environment visualized is one somewhat similar to that of the present-day Bahaman banks with warm shoal waters, described in considerable detall by Illing (1954) and Newell and Ribgy (1956). The term "bahamite" has been proposed Ior Ilmestone of this type depos1ted over large 1solated marine banks or in coastal shoal belts and small off-shore banks (Beales, 1958, p. 1851), in distinction to clastic, detrital calcarenites derived from subaerial erosion of highlands. The writer feels that this term is appropriate to describe the carbonate part of the Worelos formation.

Dolomitization and silicification.--Dolomitization is thought to have occurred on the sea floor before and during diagenesis of the calcareous sands and muds. Dolomitized beds are completely distinct and separate from adjacent limestone beds. Dolomitization has nowhere been noted to cut across beds in the area mapped, but bedding planes everywhere serve as definitive contacts between dolomitized and non-dolomitized beds. Replacement by dolomite has ranged from a few per cent to perhaps 90 per cent in different beds. It has variously taken the form of nearly uniform dissemination of dolomite crystals through the rock (p1. 10-c and $-D$ and $p l$. 13-B), selective replacement of fossils (pl. 10-B and $p 1.13-A$ ), selective replacement of matrix rather than fossils ( $\mathrm{pl}$. 10-A), and irregular, mottled dolomitization 
without regard to fossils or matrix ( $p I$. II-C and -D). In. each case, however, the type of dolomitization described is confined to a particular bed, whether replacement be partial or nearly complete, and the overlying bed is a dis-. tinct unit.

Physical or chemical differences between two adjacent beds can not account for dolomitization in one case and not in the other, but the explanation is more likely to be found in slight differences in salinity, hydrogen-ion concentration, temperature, or chemical composition of the overlying waters, as a result of climatic and blologic variations. Mary adjacent beds of dolomite and Iimestone have nearly identical original textures and faunal content. The photographs in $A$ and $B$ of plate $I I$ and $B, C$, and $D$ of plate 12, for example, illustrate non-dolomitized foraminiferal Iimestone with fragments of rudistids, yet the photographs In $A$ and $B$ of plate 10 show partly dolomitized limestone W1th many of the same species of foraminifera and rudistids. The balance between conditions causing or preventing substitution of calcium by magnesium in the bottom muds must be extremely delicate, as neither planktonic nor benthonic Iife was significantly affected in the examples just cited. This does not mean that dolomite did not form under markedIy different conditions elsewhere, and in fact, dolomite associated with anhydrite in the lower part of the Horelos formation probably formed in a markedly different environment. 
Chert is abundant in some parts of the Morelos formation, and few beds do not contain silica in some form. Most of the chert appears in irregular, knotty to ropy nodules along bedding planes, and some of these form 1rregular tabular lenses several meters long. Smaller nodules and lenses occur within some beds, but extensive thin tabular bodies and Interleaves are absent or extremely rare in the Morelos formation, in contrast to the underlying Xochicalco formation. Chert is present in both Iimestone and dolomite beds, and it occurs in Iimestone with foraminifera as well as with rudistlds, other pelecypods, and Eastropods. Probably the greater part of the silica in the formation, however, is in silicified fossils and fossil fragments. Silicification was not uniform and certain species were more susceptible to replacement than others. The maistid genera Toucasia and Radiolites, as well as fragments of oysters, echinoids, sponges, and corals were selectively silIclfied (pl. II-A; $\mathrm{pl}$. I2-C and $-\mathrm{D} ; \mathrm{pI}$. 13-A), whereas most sastropods and foraminifera rarely show any silicification. The shell matter is replaced in such a way that all the original texture is lost, although some of the gross structure and the overall form of the shell remain intact. The greater part of the chert and of the silicification must have been produced penecontemporaneously with the limestone. The process is visualized as heving occurred in part while the sediments were still unindurated, particular- 
Iy the chert nodules and lenses on the beddins planes, but some of the rest of the chert and the silicification of the fossils may have been produced by migration of silica and replacement, after burial of the sediments and during diagenesis. A detalled description of the origin of chert in rocks similar to but somewhat younger than the Norelos formation, near Soyatal in northeastern Querétaro (pl. 3-A), was published by White (1947), and the origin of chert in Lower Cretaceous Iimestone equivalent in age to the Morelos formation, in the Zimapán mining district of west-central Hidal80, was described by Simons and Mapes (1956, p. 8-10). In short, most of the chert seems likely to have been deposited by replacement during diagenesis, but some of it was probably of syngenetic origin and deposited on beding planes. Silicification has no relation to presentday topography and is not a surficial feature, as suggested in some earlier published reports, and as a result, blocks of Iimestone with silicified fossils may be collected and dissolved in acid to release the fossils for study and identification.

\section{Weathering}

Limestone beds weather light gray to bIuish gray and heve smooth to hackly surtiaces with sharp ridges, rilis, fluting, or other solution features. Dolomitized beds weether brownish gray and have rough sandy surfaces, or, if 
strongly fractured and re-cemented by calcite, they present a criss-cross pattern of fine channels with sharp interridges or a rough "pavement" surface, typical of beds in the Morelos formation (pl. 13-B). Irregularly dolomitized IImestone produces knotty weathered surfaces. Dissolution of the calcite matrix of uniformly dolomitized rock produces dolomite sand in places where erosion is not so rapid as to remove the sand. Where nodules and lenses of chert and irregularly silicified fossils are present in the underlying bedrock, these resistant fragments are released by weathering to form a dense chert surface rubble.

\section{Anhydrite member}

The basal part of the Iforelos formation consists of an anhydrite member to the east and southeast of an irregular line extending more or less from Tequesquitengo toward Iguala and thence south-southwestward to the latitude of the Balsas River, where it probably turns eastward (fig. 1). The Iine is presumed to extend northeastward from Lake Tequesquitengo for an unknown distance, but probably not more than a few tens of kilometers, before it turns eastward and southeastward.

The only large outcrop of this member in the area mapped is on the steep hillside $1.5 \mathrm{~km}$. southeast of Tilzapotla (quad. I-5), where it has been penetrated by large quarries. The western border of the anhydrite member is 
thought to be exposed in the road cut at $\mathrm{Km} .157$ of the Amacuzac-Iguala toll road, where the Xochicalco formation is overlain by a jumble of coarse-grained dolomite of the Morelos formation, in which blocks of gypsum were uncovered when the deep cut was excavated. This is interpreted to mean that the anhydrite member was present, but only a few meters thick, and that it was almost entirely dissolved by ground waters, causing slumping and complete brecciation of the overlying and possibly interbedded Morelos dolomite. No evidence of anhydrite was found at this contact to the north, northwest, and west, but some may be present around the east and northeast sides of Cerro Tuxpan, to the east. The lowest part of the Morelos formation exposed in the Tecumán anticline between Cerro Barriga de Plata (quad. D-8). and Tecumán (quad. E-7) has a similarly massive, brecclated character and is thought to have contained some anhydrite or to have anhydrite still present below the surface. Elsewhere in the assumed area of anhydrite deposition, erosion has not cut deep enough to expose the lowest part of the Morelos formation.

Extensive areas of anhydrite and dolomite crop out south of Huitzuco, a tow 22. km. east of Iguala and $12 \mathrm{~km}$. east of the southern end of the map in plate 1 (quad. K- 3 ; f15. 1). This occurrence was mentioned in a report on mercury deposits by McAllister and Hernández-Ortiz (1945), who attributed the anhydrite and dolomite to hydrothermal re- 
placement of Iimestone, but inspection of the area by the writer revealed the sedimentary character of the rocks and their 1dentity with anhydrite and dolomite farther north. Other outcrops occur $6 \mathrm{~km}$. east of Apipilulco in the valley of the Iguala River only $20 \mathrm{~km}$. or so south-southwest of Iguala (fig. 1). These deposits were described as "gypsum" by Santilián (1929, p. 98-99), who also ascribed them to metasomatic replacement of Iimestone.

The anhydrite is laminated, white to dark gray, and highly contorted by flowage. Surficial material contains a considerable admixture of gypsum, but the densest, relatively unaltered rock is nearly pure anhydrite. The sypsum is presumed to represent hydration of the anhydrite where ground waters could penetrate the rock. Exposures in the area mapped in detall were too small in extent to permit makIng a comprehensive study of the I1tholosy and exact stratigraphic relationships of the member. The effect of dissolution by ground vaters is obvious wherever the unit is exposed.

\section{Thickness}

The Morelos formation was apparentiy not deposited over the highest part of the Early Cretaceous Taxco paleopeninsula. Away from there, however, it rapialy thickens to the northeast, east, south, and southwest. In Cerro Acuitlapain only $13 \mathrm{~km}$. northeast of Taxco the formation is 
$800 \mathrm{~m}$. thick, indicating an increase of $1 \mathrm{~m}$. In thickness for every $16 \mathrm{~m}$. of horizontal distance. In the central part of the State of Morelos the thickness is probably at least $900 \mathrm{~m}$. , but the exact figure is not known because the base is not exposed. From there southward the thickness decreases to probably less than $600 \mathrm{~m}$. In the vicinity of Buenavista de Cuéllar (quad. I-4), and to only about $400 \mathrm{~m}$. near Iguela. It seems to increase again from Iguala southward.

Some of the variation in thickness is undoubtedly due to removal of the upper beds of the Morelos formation in certain places, judging from fossil evidence, but most of it is due to deposition on an irregular surface and to calcareous bank development. A striking example of the effect that Iime accumulation over a subsiding bank has on thickness variation of a carbonate formation is the EI Doctor limestone of eastern Querétaro (pl. 3-A), a lithologic and age equivalent of the Norelos formation described by Vilison and others (1955). The Cerro Ladrón bank facies of the El Doctor formation has a thickness of $1500 \mathrm{~m}$., whereas the adjacent La Negra back-reef and outer fore-reef facies is apparently less than $300 \mathrm{~m}$. thicls (op. cit., p. 4-5). The thickness difference is interpreted as being primarily a depositional feature. Another example is the El Abra formation, a lithologic and age equivalent of the Morelos formation; in the Faja de oro of northern Veracruz (fig. I). 
Bonet (1952, p. 235) reports the locality to consist of $2500 \mathrm{~m}$. of bank Iimestone ("Urgonian facies") surrounded by much thinner sequences of back-reef and fore-reef deposits.

\section{Structure and stratigraphic relationships}

Tectonic movements compressed the llorelos formation into folds with northerly trends and the rocks were fractured to varying degrees from place to place. The dolomite in particular was strongly fractured, and these fractures as well as those in the limestone beds were healed by deposition of white calcite (see $p l .10-A$ and $-C$; $p l$. 1l-A, -B, and $-D ; p I .13-B)$. Compression was not strong enough to have produced noticeable flowage of the Iimestone and dolomite, and even fracture cleavage is rare, but the anhydrite member was intensely deformed by flowage. The lack of greater internal deformation in the carbonate rocks is undoubtedly due to their thick-bedded dense character, in view of the strong deformation of overlying and underlying cretaceous units.

Basal Iimestone, dolomite, or anhydrite beds of the Morelos formation Ile with ansular unconformity upon all the earlier units, with the exception of the immediately older Xochicalco formation and possibly also the next older Acuitlapán formation, but even these two pinch out irregularly between the Taxco paleo-peninsula and the Morelos formation and may have been bevelled by erosion before the latter unit 
was deposited. Outcrops of the lower contact of the MoreIos formation in the area mapped are not sufficiently extensive to be certain of the exact relationships with the earIier Cretaceous units, but certainly the Norelos formation has a transgressive relationship to all the older rock $u$ nits in the region.

The upper contact of the Morelos formation is an erosion surface, on which different horizons and facles of the Cuautla formation were generally deposited, but locally the next overlying unit is the Mexcala formation and the Cuautla unit is absent (see fig. 2). In places where older horizons of the Morelos formation form the upper contact, the younger beds of this unit were either not deposited or were eroded, but probably the latter. Where units younger than the liexcala formation rest directiy on Morelos beds, erosion was of post-Mexcala age:

Diabasic, andesitic, and rhyolitic dikes and sills cut the formation here and there, and larger granitic and diabasic stocks are present locally.

\section{Fossils and age}

The Morelos formation is relatively poor in macrofossils, and most of those collected are elther new species, new varieties, or long-ranging forms. Rudistids are numerous in the upper part of the formation but are few in variety. Ammonoids are seldom found in rocks containing rudis- 
tids; and indeed, in spite of diligent search, none were found in the Morelos formation in the area mapped. Microfossils are extremely numerous in some beds, particularly in the upper part of the formation, and are dominated by genera that belong to the family Millolidae. Some beds are so replete with these large foraminifera, which are readily seen on fresh fracture surfaces even wlthout a hand lens, that the rock may be referred to as a "miliolidite". Other foraminifera are also present but are not so easily distinguished in hand specimen. Wost of the forms present are either lons rangins, unidentifiable beyond genus, new species, or new varieties and are not in themselves diagnostic of exact age, with three possible exceptions. Assemblages and relative abundance of the foraminiferal forms present in a particular bed are the most useful criteria for assigning an age to that bed.

A particular effort was made to determine the age of the topmost part of the Morelos formation, as well as the variation in age of the top of the unit from place to place, in order to help to decipher the tectonic history of the region. The following lists accordingly give two groups of samples and two corresponding groups of fossils, one from the uppermost, youngest part of the formation, and the other from the lowermost, oldest part. The numbers of the samples that yielded paleontologic data are as follows: 
Samples from uppermost, youngest part of Morelos formation
Samples from lowermost, oldest part of Horelos formation

F55-3I

79

92

F56-3.
15

38

67

F56-11

F-6-54

15

37

The localities from which these samples were collected, detalled descriptions of the I1thology and faunal content, and the names of the persons who identified the fauna are given In the appendix.

The fossils identified in the samples from the uppermost, youngest part of the Morelos formation are as follows:

Microfossils

Dicyclina schlumbergeri MunierChalmas

Nummoloculina heiml Bonet

Spiroloculina sp.

Nonion(?) sp.

Iagena sp.

Dentalina sp.

Bisenerina sp.

Ovalveolina sp.

Dukhania sp.

Triloculina sp.

Quinqueloculine sp.

cuneoline sp.

OphthaImidium sp.

Guttulina sp.

Cyclammina sp.

Ammobaculites cf. A. cuyleri

Lituola sp.

Massilina sp.

lasslina cf. M. planoconvexa

Palmula cf. $P$. decorata

Turrispirilina subconica (?)
Nacrofossils

Peronidella sp. cf. P. ramosissima Dunikowsky Epistreptophylium sp. cf. E. budaensis Vielis

Hyp̃osalenia(?) sp.

Spondylus sp.

Ostrea sp. Praeradioiltes(?) sp. Toucasia pategiata( $\bar{l}$ ) White Toucasia texana(?) Roemer Nerinea sp. Actaeonelia sp. Unidentifiable ostracodes Algal structures 
Among the macrofossils cited, Peronidella was identified by F. W. Wells, who states that the genus ranges from Devonian to Cretaceous, although most. described species are of Mesozolc age, especially Triassic and Cretaceous. "The specimen appears to be a new species, similar

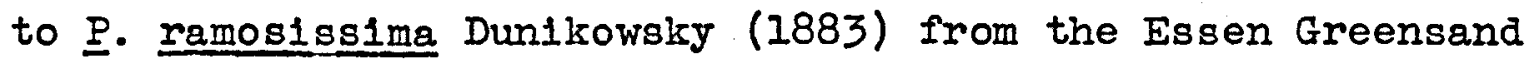
and other Cenomanian horizons in Europe" (personal communication). Eplstreptophyllum was also identified by Wells, who states that the genus ranges through the Jurassic and Cretaceous, that the specimen is tentatively identified as Eplstreptophyllum sp. cf. E. budaens1s Wells, and that E. budaensis is known from the Buda IImestone of Texas (early Cenomanian). Hyposalenia(?) was identified by C. W. Cooke, who quotes liortensen as giving the range of the genus as "throughout the Cretaceous formetions of Europe from Sequanian to Senonian". (Kimmeridgian through Maestrichtian; see fig. 2; personal communication).

I. W. Stephenson examined and identified the two sillcified specimens of Spondylus and reported that they "do not resemble closely any Spondylus from the Cretaceous of the southern states and probably represent an undescribed species. The genus is reported to range from the Permian to the Recent" (personal communication). Neither Ostrea nor Praeradiolites is of precise stratigraphic value unless the species is known. Both species of Toucasia are reported from southern Texas from the Edwards and Glen Rose Iime- 
stones, of early and middle Albian age, and similar species occur in the Devils River limestone of late Albian age, and even in the Buda limestone of early Cenomanian age, according to R. W. Imlay (personal communication). Although the writer is not positive of his identification of these two species, he thinks nevertheless that their range in Mexico is greater than heretofore described by Mflierried (1944, p. 471), or middle Albian, and that they probably continue on up into the appropriate facies of Cenomanian rocks in Mexico as well as in Texas.

The foraminiferal benera and species, taken separately, do not define an exact age for the enclosing rock, as most of them are long ranging. Only two species are of especial value in fixing the joungest age of the Norelos formation. These are Dicyclina schlumbergeri Nunier-Chalmas and Nummoloculina heimi Bonet. The former has been described by Bonet (1956, p. 20-21, table 1) as being restricted in Mexico to the Cenomanian. Studies by E. R. Applin, however, suggest that this species appeared somewhat earlier, in late Albian time (personal communication). N. helmi is described by Bonet (1956, p. 16-20) as a new species and as ranging from earliest Albian time through Cenomanian time, but it does not become abundant until middle Albian time and later. Conlin and Conkin (1958) emended both the genus Nummoloculina Steinmann and the species $\underline{N}$. heimi Bonet because of inadequate description. They state 
(op. cit., p. 150) that the Cretaceous range of NummolocuIina in Texas is through the Albian, but that where reef conditions continued, as in eastern Mexico, the genus continued on into Cenomanian time, as pointed out by Bonet. In samples from the Morelos limestone and equivalent Mexican formations studied for the writer by E. R. AppIin, N. heim1 is apparently rare below upper Albian beds, and another species of Nummoloculina, which appears even up into Iover Cenomanian beds, becomes increasingly more abundant downward in the section (personal communication). On a worldwide basis, the genus Nummoloculina ranges from Early Cretaceous to Recent, but it is rare in rocks younger than Cenomanian.

In summary, data available from both macro- and microfosils collected from the uppermost, youngest part of the Morelos formation indicate that deposition continued In the region at least into early. Cenomanian time. Evidence has not been obtained yet to prove a Woodbine (middle Cenomanian) or younger age for any part of the formation. If such younger beds should be found locally in later work, the inference would be strong that the equivalent beds were removed by erosion in the rest of the area mapped, before the deposition of the next overlying formation.

Detailed examination and comparison of microfossil assemblases in samples collected at or within a few meters of the upper contact of the Morelos formation in different 
localities in the area indicate that the age of the top of the formation varies considerably from place to place. Sample F55-53 from the first limestone ridge east of Cuautla (see appendix) represents close to the younsest top part of the formation sampled and is of early Cenomanian age. The top of the formation at $\mathrm{Km}$. 148.8 of the AmacuzacIsuala toll road, represented by sample F55-92, is clearly significantly older and is probably of late Albian age. These two localities represent the extremes among those sampled in the area mapped, others fallins somewhere between, but sampling was by no meens exhaustive. The differences in ase of the top of the Morelos formation are judged to be due to erosion rather than to non-deposition. The age of the base of the Horelos formation obviously varies greatly from place to place, particularly around the Taxco paleo-peninsula which was never completely covered by this unit. The oldest basal carbonate beds in the area are probably not exposed by erosion, but the oldest beds sampled yielded the following fauna:

Microfossils

Spiroplectamina cf. S. goodlandana

Dictyoconus sp. Nassilina cf. M. planoconvexa Nummoloculina Sp. 므 Cuneolina sp. Ophthalmidium sp. Guttulina sp.

Hacrofossils

Toucasia patasiata(?) White Toucasia texana(?) Roemer Irerinea sp. Unidentified gastropods Unidentified ostracodes

No macrofossils were found that could be used to fix the age 
with precision. Both species of Toucasia cited were described in an earlier paragraph as being characteristic of middle Albian age, but they are not entirely diagnostic. With the exception of the first two foraminiferal forms cited in the list above, the remaining genera and species occur also in the youngest part of the Horelos formation sampled. Significant differences in microfossil assemblages from the youngest and oldest beds are the different relative abundances of the genera and species present, and the absence of some of the characteristically younger forms from the older assemblages. The notable absence of the genus Orbitolina, which is present elsewhere in the forelos and equivalent formations of the same facies in southern and eastern ilexico, indicates that the basal carbonate beds exposed in the area mapped are younger than early Albian. The best age assignment for these beds, then, is middle Albian.

Inasmuch as the anhydrite unit underlies the carbonate beds, it is somewhat older and may have been deposited in early Albian time. The presence of the underlyins Xochicalco formation, of Aptian-Barremian age, places a lower ase Ilmit on the anhydrite member. That this member belongs to the lforelos formation rather than to the Xochicalco formation is proved by the close association of dolomite and anhydrite in the lower part of the iorelos unit, and the complete change in facies from beds that make up the Xochicalco unit. 


\section{Correlation}

Rocks of the same general facies and age as those of the Morelos formation are very widespread over the eastern half of Mexico and they crop out from the United States border to the Guatemalan border. They account for much of the characteristic topography of the Sierra Madre Oriental. An off-shoot of this main mass extends westward through the Balsas Basin to the Pacific coast in the state of Colima and possibly also elsewhere. The name Morelos has been carried as far west as the Huetamo area (Pantoja-Alor, 1957, p. 26-30) In southeastern Michoacán (Iocality 5, pl. 3-A), and as far south as $\mathrm{Km}$. 350 of the Acapulco highway, south of the Papagayo River (f18. I; Fries, 1956b, p. 297). In many earlier published and unpublished reports reference has been made to the formation in Michoacán, Guerrero, western Oaxaca, and southwestern Puebla simply as Midale Cretaceous Iimestone (Guzmán, 1950, p. 121), the Cretaceous system having generally been divided in Mexico into three series, called Lower, Middle, and Upper. In central Pue-. bla the equivalent unit is called by various names, of which Cipiapa and Maltrata (Calderón-García, 1956, p. 21-22, Iig. 4) refer to Ilmestone unlts of early Albian age, and Escamela is used for younger limestone but without defining exact age Iimits.

In eastern Querétaro ( $p l$. 3-A) the equivalent unit Was named the EI Doctor Iimestone by WIIson and others 
(1955, p. 2-3). This name was extended southward by Segerstrom (1956, p. 312-313) as far as the southernmost limestone outcrops north of Mexico City, and it was extended northward by Bodenlos (1956, p. 295-296 and 302) to southeastern San Luis Potosi (locality 7, pl. 3-A). Northward and eastward from the latter locality the names applied to the unit are mainly El Abra, Tamaulipas, and Taninul, each of which represents a somewhat different facles of the same unit, but all these facies occur within the El Doctor limestone alone. As in the Morelos formation, both upper and lower age boundaries of these other formations vary from place to place, within the interval from early Albian to early Cenomanian time.

\section{Cuautia formation}

Distribution and physiographic expression

The Cuautla formation (Fries, 1956c) takes 1ts name from the city of Cuautla (quad. E-9), because of the excellent exposures of the unit in the low ranges to the west of there. The formation consists of three major facles, which consist of I) a thick sequence of medium- to thick-bedded Iimestone beds of calcareous bank or "bahamite" type, 2) a thinner sequence of thin- to medium-bedded laminated limestone beds, and 3) a very thin sequence of thin- to mediumbedded clastic limestone beds. All three facies grade into each other laterally and were mapped as a single formation, 
as they together form a mappable unit that is separable from the underlying and overlying Morelos and Mexcala formations. The facies could undoubtedly be delimited areally, however, by a more detailed study of the formation than the writer could undertake for the present report. In the discussions that follow, the thick calcareous bank facies will be understood unless specific reference is made to another facies of the Cuautla formation.

In the northeastern and eastern parts of the area mapped, the outcrop area of the bank facies of the Cuautla formation is nearly coextensive with that of the underlying Morelos formation, but in the western and southwestern parts of the area the unit is thin or even absent and has not been shown separately on the map in plate 1 . In the latter area the unit is generally less than $25 \mathrm{~m}$. thick. Where it is thick bedded, it is included with the outcrop of the Morelos formation, because of the lack of time needed to separate the two when the field work was being done in that area. Where it consists of thin-bedded limestone, however, it is included in the outcrop area of the Mexcala formation, for the same reason. In any event, the outcrop of the unit would generaliy not exceed the width of a thick Iine on the scale of the map in plate 1.

The Cuautla formation continues southward and westward from Iguala as a thin limestone unit for an unknown distance, but it continues southeastward and eastward from there 
as a thick calcareous bank facies into northeastern Guerrero, as well as eastward from the state of Morelos into southwestern Puebla, also for an unknown distance. Northward from Morelos it continues beneath the Tertiary cover and reappears near Apaxco, where it crops out as a bank facles from place to place as far north as the west-central border of the state of Hidalgo (pl. 3-A; fig. I).

The phjslographic expression of the thick bank facies of the Cuautla formation is similar to that of the underlying Morelog formation, reflecting the similarity in bedding, structure, and texture. The only significant difference in resistance to erosion between the two units is the relative freedom from dolomite of the Cuautla formation, a factor that is expressed physiographically in greater resistance to weathering and erosion and in weaker development of karst features. The unit tends to produce cliffs wherever slopes are steep. The most prominent physiographic features determined in large part by the Cuautla formation are the four nearly parallel mountain ranges leading southward from the vicinity of Tepoztlán, Yautepec, San Carlos, and Itzamatitlán in the central part of sheet 1 of plate 1. The upfaulted southern extensions of some of these ranges, such as Cerros Temilpa, Santa María, and Jojutla, may be seen in the oblique air photograph in plate 5 . 


\section{Iithology}

The dominant facies of the Cuautla formation in the area mapped consists of thick-bedded to massive, dense I1mestone composed of calcilutite, calcisiltite, and calcarenite of "bahamite" or calcareous bank type (pI. 14-C and -D; pl. 15-B). Few beds are less than $20 \mathrm{~cm}$. thlck, and some of the uppermost beds in the northern part of the area, southeast of $\mathrm{Km}$. 15 of the Cuernavaca-Cuautla highway (quad. D-7), are $4 \mathrm{~m}$. or more thick. The color of the limestone varies from light to dark gray and, less commonly, black, and clastic beds near the lower contact are locally reddish and jellowish. Chert nodules, lenses, and 1rregular masses are common in many of the beds and along the bedding planes, and siliclfication of biogenic fragments and fossils is particularly strong in the lower and middle parts of the unit. The orlgin of the chert and silicification is thought to be the same as that described for the Morelos formation. Blostromes of partiy to completely silicified rudistids, corals ( 1 l. 15-B), and gastropods are especially abundant in the northern and eastern areas of outcrop of this facles (pl. 16 and 17). Foraminifera are present in the calcisiltites and calcarenites, but they are not readily visible in hand specimen. Species belonging to the family Miliolidae are absent or rare. Algal structures are visible in some beds. 
Iimestone beds of the "bahamite" facies of the Cuautla formation consist of fairiy pure calcium carbonate, if the silica in chert is discounted, and beds without visibie chert contain little insoluble residue. Dolomitization has occurred only to a minor degree in this facies. Dolomitized beds are not readily distinguishable. in the field, and an outcrop of frankly dolomitized rock is more likely to belong to the Morelos formation than to the Cuautla unit. Argillaceous material of terrigenous origin is generally absent or rare.

The basal $I$ to $20 \mathrm{~m}$. of the "bahamite" facies of the Cuautla formation: north and east of the Amacuzac River consist of a varied sequence of thin to thick (5 to $50 \mathrm{~cm}$. beds of argillaceous calcisiltite, calcarenite, and conglomerate made up of eroded and abraded detrital clastic grains of limestone and dolomite, with some admixture of chert particles and abraded large foraminifera (miliolids), all derived from the underlying Morelos formation (pl. 13-C and $-D$; pi. I4-A and $-B$ ), as well as abundant small forms of gastropods, locally. These beds seem to represent litoral or beach deposits at the base of the calcareous bank. A different facies of the Cusutla formation is well exposed about $I \mathrm{~km}$. east of Tlaquiltenango (quad. G-7) and thence southeastward along the strike for some $9 \mathrm{~km}$. Beds in this facies are generaliy 5 to $20 \mathrm{~cm}$. thick, chert is in the form of incompletely replaced interleaves or laminae 
rather than nodules, biostromes of rudistids and gastropods are absent, dolomitization is more extensive (but still relatively unimportant), and the entire section is less than half as thick as the section in the next outcrop area to the east, which consists of the "bahamite" facies. Chips taken from a series of six beds (sample F-64-54) judged in the field to contain the least and the most dolomite in this facies were analyzed by $E$. Schmitter of the Mexican Institute of Geology, who found extremes of 0.0 and 67.7 per cent dolomite, and 0.6 and 7.8 per cent insoluble residue, which consisted largelf of silica. The section sampled contalned several beds that weathered with a sandy surface, $\therefore$ like that of dolomite beds in the liorelos formation, but such beds were not observed in the thick "bahamite" facies. A subfacies of the bank facles crops out from 1 to $2 \mathrm{~km}$. northeast of Nexpa, alons the Chinameca River (quad. E-7). Beds of very coarse Ilmestone breccia with blocks up to $30 \mathrm{~cm}$. Ions occupy a narrow zone between normal thick beds to the north and a very thin sequence of thin calc1slitite and calcarenite beds along the south side of the river. The area evidently represents the border of a bank and must be close to a shoreline to the south or southwest. All the beds to the southwest of the Amacuzac River that were identified as belonging to the Cuautla formation, or thought to represent this unit, consist of calcilutite in small part but mainly calcisiltite and calcarenite with 
a variable, small admixture of argillaceous and, rarely, carbonaceous matter. They form the third major facies of the Cuautla formation and seem to represent litoral or nearshore deposits. They are composed in part of clastic, detrital limestone and dolomite grains eroded from an exposed carbonate terrain, but with some admixture of indigenous comminuted biogenic fragments. In most of this southwestern area the thin clastic beds were included, for mapping purposes, with the overlying Mexcala formation, with which they are more closely allied in facies than with the underlying, thick, miliolid-bearing limestone or dolomite beds of the Morelos formation.

\section{Thickness}

The thickest part of the Cuautla formation corresponds to the "bahamite" or calcareous bank facies and totals about $750 \mathrm{~m}$. In thickness. It occurs in the mountain range defined by Cerro Barriga de Plata, Monte Negro, and Cerro Ectopan (quad. D-7 to E-7), and it continues for an unknown distance form there eastward and southeastward, beyond the edge of the geologic map. Southward the thickness also continues nearly the same into Cerro Santa Marla (quad. G-7), but in the next anticlinal ridge only $2 \mathrm{~km}$. to the southwest of the latter range, it decreases to less than $500 \mathrm{~m}$. Westward from the Santa Marfa-Barriga de Plata mountain range the Cuautla formation rapidly decreases in thickness to only 
a few meters in a horizontal distance of 20 to $25 \mathrm{~km}$. At a point $7 \mathrm{~km}$. northeast of Taxco the unit is only $20 \mathrm{~m}$. thick, and some $12 \mathrm{~km}$. south of Taxco $1 \mathrm{t}$ is only $15 \mathrm{~m}$. thick, while in the immediate vicinity of Taxco beds recognized as belonging to the formation have not been identified and were probably not deposited. In the vicinity of Iguala at the south end of the area mapped, the unit may consist of a few meters of thin Iimestone beds that were mapped with the Mexcala formation, yet near Hultzuco only $20 \mathrm{~km}$. to the east of there (fig. 1), the Cuautla formation is present in a thick bank facies similar to that farther north. The thickness thus seems to have been controlled by the nearly northsouth paleo-shoreline, to the west, and the development of the Cuautla calcareous bank to the east.

\section{Structure and stratigraphic relationships}

The structural features described in the lorelos formation are also characteristic of the Cuautla formation, as the two participated in the same tectonic movements, and hence they need not be repeated here. The Cuautla formation everywhere rests directly upon the Horelos unit. The fact that different stratigraphic horizons and lithologic types of the latter unit appear locally under the Cuautla Iimestone at relatively short distances laterally indicates that a period of marine withdrawal and erosion separated the two formations. This conclusion is further strengthened by 
the presence of basal clastic beds in the Cuautla formation, of which the constituent grains were derived from the MoreIos formation. The argillaceous fraction of the basal beds may represent insoluble residue from subaerial weathering and dissolution of the Morelos limestone and dolomite, and the dolomite grains may have been liberated by disintegration of dolomite beds to sand as a result of leaching of the cementing calcite matrix. No angular relationship was noted between the two formations on an outcrop scale.

The next overlying unit consists of the kexcala formation, which rests conformably on the Cuautla limestone without evidence of an intervening erosion period. Later erosion, however, removed the Mexcala unit in many places, and as a result, any one of the jounger formations may rest directly upon the Cuautla unit, but everywhere with great angular unconformity. In the southwestern part of the area mapped, the lowermost part of the overlying Nexcala formation may be equivalent in age to the upper part of the Cuautla bank facies farther to the east.

\section{Fossils and age}

The "bahamite" or calcareous bank facies of the Cuautla fornation contains repeated biostromes of malstids and gastropods, from the basal part of the unit upward to near the top, but the topmost, youngest beds of this facies in the area between Cuernavaca and Cuautla are devold of 
identifiable macrofauna. Most of the rudistids are partly to well silicified and can be recovered by dissolving the Iimestone in a dilute solution of hydrochloric acid. Except for well silicified small gastropods in the basal calcarenite beds that belong to the genus Nerinea, most of those higher in the formation are not silicified, regardless of genus. Individuals of the rudistid genus Durania, for some unknown reason, rarely show even incipient silicification although they may occur together with abundant, well silicified individuals of other rudistid genera. Both rudistid and gastropod groups seem to contain new species in addition to earlier-described forms. No attempt was made to name and describe the nev species, but only to list them as indeterminate. Just as in the Morelos formation, ammonoids are absent in the rudistid-bearing facies of the Cuautla formation.

The following list gives the numbers of the samples collected from the lower, middle, and upper parts of the Cuautla bank facies, for convenient reference to the appendix, in which the provenance, Iithology, and faunal content of each sample are described.

Upper part of Middle part of Lower part of Cuautla bank facies Cuautla bank facies Cuautla bank facles

$\begin{array}{ccc}F-22-50 & F-12-50 & F-23-50 \\ 44 & 13 & 34 \\ 83 & 45 & 63 \\ F-66-54 & F-23-53 & F-4-54 \\ F 55-42 & F-12-54 & 23 \\ 48 & 22 & F 55-13\end{array}$


The faunas corresponding to each of the above groups of samples are listed below, in such a way that the forms in the upper part of each column are generally in a higher part of the section than those lower in the column, but some of the species Iisted are present throughout the group, as evidenced by comparing groups.

Upper part of Cuautia bank facies

Mult1columastreae cyathiformis (Duncan

Columastraea sp. Durania cornu-pastoris Trochactaeon sp. close to T. occidentalis

Actaeonelia sp. Hippurites sp. a Hippurites sp. $\bar{b}$ Hippurites resectus var: mexicanus (Bárcenz) Müllerried

Radiolites mülierriedi Bauman Radiolites sp. Nerinea sp. Toucasia sp.
Middle part of Cuautla bank facies Cuautla bank facies

Lower part of
Durania cornu-pasto-Hippurites sp. ris (Dés Moulins) Radiolites müllerParona. Hippurites sp. a Hippurites sp. $\bar{b}$ Radiolites perforata PaImer Toucasia sp. tus var. mexicanus (Bárcena) MUll- Nerinea sp. (2) lerried Radiolites sp. Radiolites müllerriedi Bauman Actaeonella sp. Nerinea sp. Tetrasramma (?) sp. Toucasie sp.
Dissocladella sp. Acicularia sp. Neomeris ci. N. cretacea Boueina sp. Halimeda sp. Holosporella cf. H. siamensis

In view of the diagnostic macrofossils present in and collected from the Cuautla formation, no effort was made to submit material for microfossil study, except three samples from the basal clastic calcarenite beds under the "bahamite" bank facies. These were samples F-31-54, F-33-54, 
and F55-4. The thin-bedded, clastic calcarenite facies of the Cuautla formation, in the western and southwestern parts of the area mapped, contains few macrofossils and these are mainly fragmental or so poorly preserved that 1dentification is impossible. Accordingly, a sample (F57-43) was collected for microfossil study at the junction of the Cacahuamilpa-Alpuyeca and the Taxco-Cacahuamilpa highways near the Cacahuamilpa Caverns a few kilometers north of the edge of the map in sheet 2 of plate 1 (quad. E-3; fig. I). The stratigraphic position of this latter sample in relation to the bank facies is not know, but the sample represents the topmost Iimestone beds assigned by the writer to the Cuautla formation at that locality. The faunas identified are as follows:

Basal clastic calcarenite un- Topmost beds of the western, der the "bahamite" banis facies clastic limestone facies

Quinqueloculina sp. Nirumoloculina heimi Bonet D1cyclina schlumbergeri Munier-Chalmas Cuneolina sp. Pithonella ovalis (8) Calcisphaerula inominata ( 8 )
Planulina cf. Planomalina opsidostrobe Loeblich and Tappan

Ammotium braunsteini(?) (Cushman and Applin).

Ammobaculites cf. A. cuyIeri Tappan Massilina sp. Quinqueloculina sp. (2) Triloculina sp. Globotruncana (i)

Cuneolina (?)

Dicjelina (?)

The macrofossils include several species of considerable use in fixing the age of the Cuautla formation. The 
coral species Multicolumastraea cyathiformis was identified by J. W. Wells, who states that it was "originally described from the Rudist limestone of Jamaica, of Campanianliaestrichtian age, and noted elsewhere only by myself in a collection made by Bruce Wade many years ago from the Cárdenas beds (San Iuis Potosi) of Mexico, Exogyra costata zone, considered to be Mrestrichtian.... I suspect that (1t) has a longer range than the two known occurrences would sugsest" (personal communication). Wells also ldentified the coral species Columastraea $\mathrm{sp}$., of which he writes that "the specimens represent a new species of the scleractinian coral senus Columastraea, a reef-building type. This is the first record of this genus in the American Upper Cretaceous. The most typical occurrence of this genus is in the European Upper Cretaceous (Turonian-Coniacian)" (personal communication).

The rudistid species Durania cornu-pastoris (Des Moulins) Parona (see pl. $17-\mathrm{A}$ and $-\mathrm{B}$ ) is described by Müllerried (1950, p. 228) as occurring in Europe exclusively in upper Turonian rocks and as not having formerly been found in America. The gastropod Irochactaeon sp. was identified by N. F. Sohl, who rrites that "the incompletely silicified gastropods of this collection are insufficient for specific identification. Böse has described a form "T. occidentalis". from the "Lower Senonian" of San Luis Potosi which appears to asree in size but has less pronounced shoulders than the 
material from Morelos" (personal communication). The mudistid Hippurites resectus var. mexicanus (Bárcena) (see p1. 16-B and p1. 17-B) was re-defined by Müllerried (1930, p. 63), who points out that this species first appears in Europe in upper Turonian rocks and is almost surely of the same age in Mexico. Both Radiolites müllerriedi and $\underline{R}$. newelli were named and described by Bauman (in press), who considers them to be of Turonian ase. Radiolites perforata was described from Huescalapa, Jalisco as a new species by Palmer (1928, p. 8I-82), who further states that "species similar to those described from Huescalapa are very comon In the Iimestone east of Cuernavaca in the State of Morelos. This genus affords the best means thus far known for correlating many widely separated exposures of the Turonian" (op. c1t., p. 80).

The algal remains were studied by $R$. Rezak, who gives the following ranges for the species and genera identified: Dissocladella sp., Late Cretaceous to early Tertiary; Acicularia sp., Cretaceous to Recent; Neomeris cf. iN. cretacea, Cenomanian; Boueina and/or Halimeda, Cretaceous to Recent; Holosporella cf. H. siamensis, known prevlously only from the Triassic. The assemblage is accordingIy of probable Cenomanian age, although this is not proved. The echinoid Tetragramma(?) sp. was Identified by C. H. Cooke, who comments that "liortensen gives the range of Tetragramma as 'Upper Jurassic (Sequanian) to iilddle Creta- 
ceous (Cenomanian)'. There is a species in the Washita group and another in the Fredericksburs group of Texas." N. F. Sohl examined the small gastropods from the base of the Cuautla formation and distinguished at least two species of Nerinea, one of which "bears a thin faint plication on the floor of the whorl, a feature found in N. burckhardt1 Böse from the 'Lower Senonlan' near Cárdenas (San Luis POtosf), but differs in being more obese in outline. Further comparison is impossible as few descriptions of such material from Hexico have been published and (the species) do not compare with any Gulf Coast forms" (personal communication).

A specles of Toucasia that is not named specificalIy in the present report ranges through the Cuautla formation from the lowermost beds (see pl. 14-D) almost to the topmost beds, although 1t becomes less abundant upward in the section. Llmestone blocks with silicified individuals (see p1. 17-A) were dissolved in dilute hydrochloric acid and among the broken fragments recorered, three individuals retained the second valve, which is a nearly flat operculumlike cover. A spec1men from sample.F-34-50 was examined by R. W. Imlay, who reports that "the species of Toucasia..... differs from both T. texane (Roemer) and T. pataglata (Whitel) by its nearly flat right valve. Its larger left valve resembles the low-spired variety of T. patagiata. The latter appears to have a more highly frilled keel and a more flat- 
tened upper surface, but the differences are minor. T. tex-

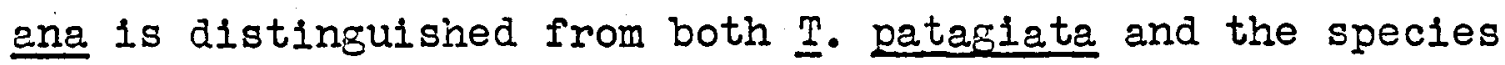
from southern Mexico by its depressed spire, which scarcely rises above the flat upper surface of the last volutions and by the volutions increasing in height and breadth more rapidly during srowth" (personal communication).

The microfossils in the basal clastic calcarenite under the "bahamite" bank facles are in part eroded out of the underlying Horelos formation. The species of that orisin are Quinqueloculina sp., Nummoloculina heimi, and Dicyclina schlumbergerl (see $p l .13-C$ and $-D$ ), in the judgement of the writer. Species that are indigenous to the rock are thought to be Cuneolina sp., Pithonelia ovalis, and Calc1sphaerula inominate.

Sample F57-43 from near Cacahuamilpa contains a somewhat anomalous and puzzling assemblage of microfossils, which is at least different from assemblages found in either the underlying Morelos formation or the overlying Mexcala formation. Examination of thin sections suggests to the writer that Individuals of some genera, as for example Dicyclina, Quinqueloculina, Triloculina, and Massilina may have been released from the underlying Norelos formation by weathering and erosion, to be incorporated as silt-sized grains in the clastic calcisiltite and calcarenite beds, possibly accounting for part of the anomalous nature of the assemblage. E. R. Applin, who studied the fauna and identified the forms 
present, judges that the general aspect of the assemblage sugsests a late Cenomanian ase. Obviously, a detailed study of the microfauna in the "bahamite" facies of the Cuautla formation is desirable, for comparison purposes, and it may shed further light on the age problem of the calcarenite facles.

To summarize the partly conflicting evidence cited in the preceding paragraphs, the macrofossils of the thick calcareous bank facies of the Cuautla formation suggest that the basal beds are of early Turonian age, but the basal calcarenite may be as old as late Cenomanian. The top of the facies is almost certainly of late Turonian age. Some of the forms reported range elsewhere upward in the time scale, but no positive evidence is available to indicate a post-Turonian age for any part of the Cuautla unit. The thin clastic calcarenite facies may be equivalent to the lowermost part of the banis facies and may actually be partly of late Cenomanian age. The top of this facies, however, is almost certainly of Turonian age, but it may not rise very high in the Turonian stage. Near-shore rocks equivalent to the upper part of the banis facies may consist of interbedded siltstone and sandstone, which the writer has included in the overlying hexcala formation. It must be remembered that the formations described in the present report are mappable I1thologic (Iithostratigraphic) units which may, and undoubtedly do in fact cut across time lines, 
if the formations are traced laterally.

\section{Correlation}

Rocks corresponding in both lithology and age to the Cuautla formation have not been described west of the area mapped, except for an unnamed limestone unit at Huescalapa (Palmer, 1928, p. 9) in the southeastern part of the State of Jalisco (pI. 3-A). Rocks of the same age but of different lithology, consisting of marine clastic sediments instead of limestone, are probably rather widespread west of Taxco but have not been mapped separately except in the Huetamo region, where they have been named the Mal Paso formation (Pantoja-Alor, 1957, p. 30-37). The lower part of this formation may be equivalent in age to part of the cuautia formation, but the facies is quite different. Rocks of Turonian ase are present in Guerrero also south of the area mapped. Between Iguala and Chilpancingo a thin-bedded clastic Iimestone unit between the Horelos and Miexcala formations is equated with the Cuautla formation by Bohnenberger-Thomas (1955, p. 23-26). Rocks of Turonian age are described near Tixtla, west of Chilpancingo (fig. 1), by iüllerried (1945, p. 257-263), who does not, however, present a Iithologic section and only states that they consist of interbedded shale and sandstone with limestone "lenses". Most of his "Upper Cretaceous" rocks are of post-Turonian age, but some Iimestone beds are apparently present at the base 
of the section. Guzmán (1950, p. 128-134) also describes "Upper Cretaceous" rocks in central and northeastern Guerrero, most of which are of post-Turonian age and equivalent to the Mexcala formation of the present report, but some Turonian Iimestone seems to be present at the base of this series of rocks.

Rocks of sinilar Iithology and age to both bank and clastic facies of the Cuautla formation crop out in southwestern Puebla and northwestern Oaxaca (f1E. I and pl. 3-A), where they were named the Petlalcingo formation by Salas (1949, p. 114-118) and are further defined and described by Erben (1956, p. 27-30). Limestone predominates in the Petlalcinso formation, but interbeds of calcareous siltstone and shale are also present. The lithology apparently varles widely from place to place. Farther north in western Puebla the "Escamela" formation seems to comprise most of the Cretaceous rocks and may include some Iuronian limestone. North of the area mapped, in the vicinity of Apaxco at the Hidalgo-Iéxico State boundary line, the Cuautla bank facies reappears from under the Tertiary cover and continues northwestward from there into southwestern Hidalgo. The name Cuautla has been retained for this facies (Segerstrom, in press), but a thinner-bedded clastic limestone unit with scattered thin shale interbeds lyins to the east of the outcrop belt mentioned has been correlated with the Soyatal formation, which was named by Vilison and others (1955, p. 3) 
for outcrops in east-central querétaro (pl. 3-A). The Soyatal formation is considered to be mainly of Turonian age. In northernmost Hidalgo and southeastern San Luis Potosf, limestone beds equivalent to the soyatal formation have been called the Agua Nueva formation, which forms the lower unit of the Xilitla group as defined by Bodenlos and Bonet (see Bodenlos, 1956, p. 302-303).

\section{Wexcala formation}

Distribution and physiographic expression

The name Mexcala formation was suggested by the writer (1956c) for the sequence of interbedded calcareous sandstone, siltstone, and shale beds, with minor clastic Iimestone lenses, that overlies the cuautla formation in the area mapped and southward from there. The name refers to both the tow and river near $\mathrm{km} .220$ of the Acapulco highway (fig. 1), about $40 \mathrm{~km}$. beyond the south edge of the map in plate 1 . The unit is so tightly folded that repetition of beds is the rule and the true lithologic sequence can not generally be determined with certainty. The type 10cality was therefore chosen along the liexcala or Balsas RIVer just east of the highway bridge, because this locality seemed to heve the least folded and most easily accessible section in a very large resion. The unit at the type locality was described in detail by Bohnenberger-Thomas (1955, pl. 5 and 6) in an unpublished thesis on the seology between 
Iguala and Chilpencingo.

The liexcala formation crops out in synclinal belts in many parts of the area mapped. It is best exposed southwest of Taxco, as well as north and south of $\mathrm{km}$. 137 of the Amacuzac-Taxco highway (quad. G-3). The west flank of the mountain range from Cerro Barriga de Plata (quad. D-7) southward to Cerro Santa María and thence down the Chinameca River (quad. H-7) consists of nearly continuous outcrops of this formation. Other good exposures are to the west and southwest of Cerro Jojutla (quad. $\underline{H}-6$ ). The unit. continues southward into central Guerrero, southwestward into northwestern Guerrero, westward for perhaps $20 \mathrm{~km}$. Into the State of liéxico, northward into the State of Hidal80, and eastward into western Puebla and Oaxaca. It has transgressive relationships to all older Cretaceous formations in the vicinity of Taxco, and it may have the same relationship to the west and south of there.

The Hexcala formation is poorly resistant to erosion and tends to form lowlands, except where it is held up or protected by adjacent higher limestone outcrops. Topography developed on $1 \mathrm{t}$ is mature and is characterized by intricateIy dissected terrain with rounded hilltops or sharp ridges and $V$-shaped valleys. Drainage lines are generally dendritic and not significantly affected by the structure of the beds, except in a very broad way, owins probably to the intricate tight folding and irregular bedding attitudes. The 
best illustration of the toposraphy developed on the formation is the area southwest of a Iine between Taxco Viejo and Taxco in the midale center of the oblique air photograph in plate 7. Another illustration is the center foreground in the photograph in plate 5, between the Amacuzac River and Cerro Jojutla, but there the pattern is somewhat complicated by the constructional surface on the late PIlocene Cuernavaca formation, which partly buries the eroded liexcala formation.

Iithologic variations in the Mexcala unit affect the erosion pattern developed on 1t. This is particularly true of the lowermost, highly calcareous beds, which may make the distinction between this unit and the thinner-bedded facies of the underlying Cuautla formation difficult to make. The only other formation in the region that may have a physioGraphic expression somewhat comparable to that of the typical Hexcala formation is the overlying Balsas clastic group, where the member in contact with Niexcala beds is composed of poorly indurated silts and sends. Such an area appears in the center foreground of the photosraph in plate 6, along the highway to the right of santa $F e$, and also in the area east and southeast of Iguala, as far south even as Zumpango del Río (fig. I). 


\section{Litholosy and thickness}

The Mexcala formation is highly variable in lithology, both latera.lly and across the section. The basal part is nearly everywhere calcareous and may consist of either argillaceous limestone or calcareous siltstone beds aggregating from a few meters to perhaps $30 \mathrm{~m}$. In total thickness. The basal limestone, where present is made up of dark-gray, somewhat laminated clastic calcarenite beds from 10 to $20 \mathrm{~cm}$. thick. The change in lithology from that of the underlying unit is abrupt where the latter consists of the Cuautla bank facies, but where the clastic limestone facles of the Cuautla unit is present, a distinction between the two is difficult to ingke without the aid of fossils. The latter condition prevails in the western and southwestern parts of the area mapped.

On top of the Iimestone are interbedded shale and calcareous siltstone, with minor sandstone. Upward in the section the sandstone or subgraywacke interbeds become increasingly abundant, and fine-grained conglomerate beds also appear. The clastic beds range in thickness from a few centimeters, for the finer-grained rocks, to more than a meter for the sandstone. Fine-grained beds show lamination and coarser-grained beds show crossbedding. Ripple marks and other Irregular markings are common on the sandstone bedding planes. 
In thin section the fine-grained sandstone or subgraywacke in the lower part of the formation is seen to be made up largely of detrital clastic grains of Iimestone and dolomite, with quartz as the next abundant constituent, and feldspar and completely altered mafic minerals as relativeIy minor constituents ( $\mathrm{pI}$. 18-A and $-\mathrm{C}$ ). Higher in the section the carbonate grains become less abundant. Well above the base of the formation in the Taxco district and to the north of there, interlenses appear that are composed of fine-grained ilmestone conglomerate or calcirudite, which are obviously derived from the underlying formations as some grains contain millolids. Conglomerate beds higher in the formation contain much larger quantities of quartz grains and other igneous minerals.

The lower part of the formation contains considerable carbonaceous matter in the form of woody stems in silty and sandy beds and on beddins planes. Some siltstone beds are black from admixture of more finely comminuted and disseminated carbonaceous matter (pI. 18-E). Distribution of the carbonaceous beds was not studied in detall, but information at hand indicates that it may be relatively local rather than widespread. Carbonaceous matter is not confined to a single horizon, although it is certainly less abundant upward in the section. Basal calcareous siltstone or argillaceous limestone beds contain fish scales in some places, together with foraminifera (pl. 15-A), pelecypods, 
and ammonoids, but microfauna is scarce in most of the formation, and macrofauna is even scarcer above the lower 200 m. or so of the unit.

Colors are also variable laterally and vertically, but dark shades predominate. The most common color in fresh exposures is dark olive gray, although locally beds may be purplish, reddish, black, and even green. The overall color in weathered outcrop is light to dark brown. An unusual weatherins color appears along the Amacuzac-Taxco highway. between $\mathrm{Km} .144$ and $\mathrm{Km} .147$ (quad. G-2), where remnants of the overlying Tilzapotla tuff lie on the Mexcala formation. The so1l, subsoil, and even bedrock for several meters below the contact have a marked bright redalsh stain, a feature interpreted to indicate a lateritic type of weathering before the tuff was deposited.

The complete original thickness of the Mexcala formation can nowhere be measured because the upper part of the unit was eroded to an unknown extent before the next overlying, Tertiary formation was deposited. Moreover, compression was so intense that the unit is closely folded even on a small scale, and beds are thus repeated an unknown number of times in almost any locality chosen for measurement. The great width of the outcrop belts, as well as the relatively great total relief on the formation, indicate that the thickness must be more than several hundred meters, but no reliable estimate can be made in the area mapped. The closest 
reliably measured section is that of Bohnenberger-Thomas (1955, p. 27-28), at the type locality along the Mexcala River for about $3 \mathrm{~km}$. east of the Acapulco highway bridge (fig. 1). Calculations based on a Brunton and pace traverse, taking into account changes in bedding attitude, gave a total of $1220 \mathrm{~m}$. This is not, of course, the full original thickness, which must have been considerably greater in view of the long time lapse before the next formation was deposited (possibly Santonian to late Eocene or early Oligocene time, or perhaps 25-35 million years). An independent estimate of the thickness made by H. Jenny in an unpublished report and c1ted by Bohnenberger-Thomas (op. c1t., p. 28) is $1290 \mathrm{~m}$. Although the thickness of the unit still present varies widely from place to place, the writer thinks that a nearly equal thickness may remain in the vicinity of the Amacuzac River, in the Higuerón syncline on the west side of Cerro Jojutla (eastern border of quad. H-6), judging from the coarseness of the higher beds in that locality, and possibly also in the San Gaspar syncline to the north of Cerro Jojutla.

Stratigraphic relationships, structure, and metamorphism

The Hexcala formation generally rests upon the Cuautla formation, either on the calcareous bank facies or on the clastic Iimestone facies, but locally the Cuautla unit is apparently absent and the next underlyins, Norelos formation 
appears at the contact. In the Taxco district, where the Early Cretaceous paleo-peninsula crops out, the Mexcala formation locally rests directly upon the Paleozolc Taxco schist without any intervening formations, but in some places 1t may rest upon one of these intervening units. The formation appears to be conformable with the underlying Cuautla formation in the area mapped, and ne1ther angular nor erosional relationships were noted. The fact that Iimestone and dolomite grains eroded fram the cuautla and Morelos formations make up clastic calcarenite and calcimalte beds and lenses, even in the lower part of the Mexcala formation, indicates, however; that uplift had occurred somewhere in the region to supply this detrital material. In view of the apparent dominance of eroded Morelos debris in these clastic beds, the writer thinks that the major uplift or deformation began in the interval between the Morelos and Cuautla formation, as indicated in the chapter on the latter unit, and continued through Cuautla and Mexcala time.

No marine deposits are known to have overlain the Nexcala formation at any time, and the next overlying formation may be any one of the Tertiary units; besinning with the Balsas clastic group, with great angular and erosional unconformity.

A period of strong deformation occurred after the Nexcala formation was deposited. This resulted in the pro- 
duction of northerly trending major structures and smaller-scale close folding of this relatively incompetent clastic unit, with the development of repeated, chevrontype folds, abundant small thrusts, and much shearing of some beds. Coarser-grained beds were fractured and secondary calcite healed the Iractures: By far the most severe effect of folding is exhibited in the Taxco district, where the Taxco paleo-peninsula acted as a more rigid basement asainst and over which the Mexcala formation was shoved and deformed. The result was to produce abundant overturned folds and. thrusts and to metamorphose the shale and siltstone beds to low-Erade phyllite (see pl. I8-E), accompanied by the development of flow cleavage and fissility in the calcareous beds. The Mexcala unit at the contact with the schist has been strongly mylonitized from place to place. Intense shattering occurred in:some beds, with healing by abundant white calcite and minor quartz veinlets. Good exposures of the metamorphosed Mexcala rocks appear in the road cuts from Km. 161 to $\mathrm{Km} .166$ of the Taxco-Iguala highway (quad. $\mathrm{H}-\mathrm{I}$ ).

Another locality in which the unit is unusually strongly deformed and weakly metamorphosed is traversed by the Amacuzac-Taxco highway between $\mathrm{Km}$. 138 and $\mathrm{Km} .146$ (quad. G-2). The cause of this local feature appears to be the large fault along the base of cerro Acuitlapan and the meeting of two divergent fold axes in that locality. Defor- 
mation and incipient metamorphism are stronger in the lower beds of the formation than in the higher beds, owing to deeper burial, buttressing against rigid underlying limestóne formations or metamorphic basement rocks, and finer-grained nature of the lower beds. Microfauna in these lower beds has been partly to completely destroyed or deformed beyond recovery and recognition.

Fogsils and age

Most of the mecrofossils found in the Mexcala formation have come from the lower $200 \mathrm{~m}$. of beds, but the most prolific part has probably been only the lowermost $60 \mathrm{~m}$. Both ammonolds and pelecypods are present as impressions in beds ranging in lithology from limestone to coarse sandstone, and they have been found in localities scattered from the northernmost outcrops of the formation to the exposures along the Chinameca River in the southeastern corner of the area mapped. None were found in the southwestern part of the area and none have been found high in the formation. Material is included from two locallties near Zumpango del Rfo, close to $\mathrm{Km}$. 255 of the Acapulco highway, because fossils from the beds at that place were collected and described in considerable deta1l by Burckhardt (1919, p. 81-132) and Böse (1923, p. 190-210). The writer made a new collection from the localities for re-study, in order to compare the forms present with those found farther north. 
The following list gives the numbers of the samples collected that yielded macrofossils, arranged to indicate the part of the formation from which they came. Detailed. descriptions of provenance, Iithology, and faunal content of the individual samples can be obtained from the appendix.

Middle part of the Mexcala formation

$$
\begin{gathered}
F-33-50 \\
F-17-53 \\
18 \\
22
\end{gathered}
$$

$\begin{aligned} & \text { Lower and basal parts } \\ & \text { of the Mexcala formation }\end{aligned}$
$\begin{array}{cc}\text { F-53-50 } & \text { F- } 68-50 \\ 57 & 90 \\ 59 & F-1-53 \\ 60 & 2 \text { to } \\ 61 & 15 \\ 67 & \text { F55-70 }\end{array}$

Nacrofossils identified in these samples are grouped
Middle part of liexcala formation
Lower and basal parts of the Mexcala formation
Peroniceras sp. Pteraptychus ( 3 ) Trauth Duranla sp.
Barrolsiceras cf. B. alstadenense Solger Barrolsiceras cf. B. haberfelineri von Hauer

Barrolsiceras sp.

Peroniceras cf. $\underline{P}$. subtricarinatum sturm Peroniceras cf. $\vec{P}$. Czornigi Redtenbacher Peroniceras sp.

Peroniceras cf. P. subtricarinatum Drescher

Otoscaphites cf. O. geinitzi (Jahn)

otoscaphites cf. o.. auritus (Schlüter)

"Crioceras" sp.

Didymotis ef. D. trinidadengis sommermeler

Inoceramus sp.

(Species collected from near Zumpango del Río; samples F-90-50 and F55-70)
Barroisiceras cf. B. haberfellnerl v. Hauer Peroniceras sp. Otoscaphites aff. Scaphites geinitz1 Jahin Otoscaphites aff. Scaphites auritus (Schluter)

Scaphites aff. S. geinitzi D'Orbigny Didymotis sp. 
All the species of ammonoids found in the lower and basal parts of the formation in the area mapped, as well as those near Zumpango del Rfo, are consldered by $R$. W. Imlay, who made the identifications, as being of early Coniacian age. Burckhardt had earlier described these specles and others in beds from the Zumpango del Rfo locality (1919, p. 93-117) and had considered them to be of early Coniacian age (p. 125-126), except species of "Scaphites" in the lowermost beds, which he thought were elther of latest Turonlan or earliest Coniacian age (p. 124). In this respect, Imlay comments that "Burckhardt considered that the lowest measured beds below those containing Barroisiceras were of late Turonian age because they contained small scaphitids with lateral lappets (Otoscaphites Wright, 1953) similar to species in the upper Turonian of Europe. The Turonian Identification is rather weak because similar specimens of Otoscaphites occur in the overlyins beds with Barroisiceras and Peroniceras and because otoscaphites is known from the Coniaclan in other parts of the world. Our records of the range of Barroisiceras show that it is confined to the lower Coniacian and in the western interior region (of the United States) occurs directly above Prionocyclus which marks the top of the Turonian" (personal communication). Another form that is characteristic of early Coniacian age is the pelecypod species Didymotis cf. D. trinidadensis Sommermeler, of which Imlay writes: "The common pele- 
cypods belonging to Didymotis were described by Böse (1923, p. :208-210) as species of Inoceramus.... Didymotis differs from Inoceramus by its rounded outIine, subcentral beak, thinner shell, rounded concentric ribs, irregular radiating lines and ribs, and by having a different hinge. It has been found at many places in Trinidad, Venezuela and Colombia associated with such Coniacian ammonites as Barroisiceras, Prionocycloceras and Gauthiericeras..... I have compared the specimens of Didymotis from southern Mexico with our collections from South imerica (U. S. National Museum) and find them apparently identical whth D. trinidadensis Sommermeier (1918, p. 132) from Trinidad. We have a number of fine specimens of that species associated with Barroisiceras in well cores from Trinidad. The much finerribbed D. variabilis Gerhardt occurs at a slightly lower level in the well" (personal communication).

The writer found specimens of Didymotis and Barroisiceras associated in the same beds only 20 to $30 \mathrm{~m}$. above the base of the Mexcala formation at the contact with the . Cuautla formation only $1800 \mathrm{~m}$. due southeast of EI Progreso (quad. D-7; samples F-2-53 to F-15-53), and also with Peroniceras within $10 \mathrm{~m}$. of the contact between these two formations about $1000 \mathrm{~m} \cdot$ east-northeast of Tlaquiltenango (quad. G-7). They occur with Otoscaphites and Peroniceras at several localities alons the Chinameca River (quad. H-7), also within about $10 \mathrm{~m}$. from the contact with the underlying 
Cuautla formation. In the area mapped, just as near Zumpango del Rfo, species of Peroniceras continue up into higher beds from which otoscaphites and Barroisiceras apparently drop out.

A large individual (12 cm. across) of an unidentiflable species of the genus Peroniceras (sample F-18-53), an apparently new species of Durania about $26 \mathrm{~cm}$. Ions (sample F-17-53), several impressions of Pteraptychus(?) (sample F-22-53), and a small immature individual of Didymotis were found in olive-gray sandstone beds from 400 to $450 \mathrm{~m}$. due west of $\mathrm{km}$. 17 of the Cuernavaca-Cuautla high-. way that probably represent the middle part of the Mexcala formation. Of the ammonoid Imlay says that "(it) may be compared with Peroniceras as its ribs are simple and nearly stralght, the upper part of the flank is marked by a row of tubercles, and the venter bears a keel bordered by two furrows. The colling appears to be more open than in the somewhat similar ammonite Texanites which is common in the Taylor group (Campanian) of Texas" (personal communication. He comments that the aptychi "possibly belong to pteraptychus Trauth. Very little work has been done with aptych1 and the work that has been done indicates that the 'species' are long ranging and probably correspond to families as based on the complete ammonite shell." He further comments that "neither Reeside or Cobban recali seeing aptychi assoclated with Barroisiceras in the United States", an observa- 
tion suggesting that they belons to some other ammonoid genus. According to G: A. de Cserna, the large individual of Durania is different from any of the species described from Mexico.

Milcrofauna was studied in specimens collected from varlous parts of the area mapped, as well as from different levels ranging from low to high in the Mexcala formation. Most of the samples collected from shale interbeds between sandstone beds in the middle and upper parts of the unit either contained no microfauna or the fossils were too poorly preserved for even generic identification. Several samples collected from a few kilometers west and south of the area mapped are included because of the additional light they shed upon the age and distribution of the Mexcala formation. The list that follows contains the numbers of the samples from which microfossils were 1dentified. Samples are arranged in two groups according to the part of the formation from which they came. Detalled descriptions can be found in the appendix.

High part of the Hexcala formation

$$
\text { F-20-54 }
$$

Lower and basal parts of the liexcala formation

$\begin{array}{cr}F-20 a-50 & F 55-81 \\ 91 & 96 \\ 92 & F 56-12 \\ F-28-54 & 13 \\ F 55-49 & F 57-42 \\ 68 & 44\end{array}$


The microfossils identified in the above-cited

samples are named below in the same groupings.

High part of the

Mexcala formation
Iower and basal parts of the Mexcala formation

Ammobaculites (?) sp. Spiroplectammina aff. S. paleocenlca Cushman Martinottielia sp. Gưmbelina sp. Lamarckina aff. I. I1mbata Cushman an $\bar{d}$ Todd Valvulineria $\mathrm{sp}$. Anomalina sp. Cibicides newmanae (PIummer) Planulina correcta (Carsey) (?) Haplophragmoldes (?) sp. Ammomarginulina (?) Gaudryina sp.

Praeglobotruncana delrioensis(?)

Globochaete(?)

Calcisphaerula (?) sp.

Pithonella ovalis

Planoglobulina acervulinoldes

Bolivina monilifera

Globotruncana fornicata

Globotruncana schneegans1

Globotruncana arca

Globotruncana con1ca

Globotruncana conica var. plicata

Globotruncana lapparenti Boll1

Globotruncana canaliculata

Globotruncana canaliculata var. Ventricosa

Globotruncana rosetta (Carsey)

Gümbelina elegans

Gümbelina Elobifera

Gümbelina pupa

Gúmbelina sp.

Globiserina cretacea

Globiserina sp.

Calcified radiolaria

By way of additional information, the following assemblages of foraminifera determined by paleontologists of Petróleos Mexicanos are quoted from Bohnenberger-Thomas $(1955 ;$, p. 34-35).

(Sample from about $1000 \mathrm{~m}$. above the base of the Mexcala formation, from along the Balsas River $1200 \mathrm{~m}$. east of the Acapulco highway bridge) 
(Samples from within about $50 \mathrm{~m}$. of the base of the Mexcala formation, from between $\mathrm{Km}$. 186 and $\mathrm{Km}$. 187 of the Acapulco highway and from just east of the highway bridge over the Balsas River)

Globotmuncana sigali Reichel Globotruncana sp.

Globotruncana lapparenti carinata Gümbelina striata (EhrenGlobotruncana citae Bolis Globotruncana Iapparenti Bolli Globotruncana lapparent1 bulloldes Vogler Globotruncana rosetta (Carsey) berg) Gümbelina sp. GlobigerIna sp. Dictyiomytra multicosta Zittel (radiolarian)

The species cited by Bohnenberger-Thomas from high in the formation are considered by paleontologists of Petróleos Wexicanos to be of Senonian age (Coniacian-Maestrichtian), but without indication as to the position in this stage group. Of the species cited from the lower part of the formation, Globotruncana sigali Reichel and G. lapparenti carInata are considered by the same paleontologists to be of Turonian age and the rest are of Senonian age.

In the area mapped by the writer farther north, the microfaunai assemblage from the highest part of the Hexcala formation sampled, on the east side of the San Gaspar syncline east of Emiliano Zapata (quad. E-6; sample F-20-54), is marlsedly different from that alons the Balsas River (see corresponding tables above). It is particularly different in lacking species of Globotruncana and Globigerina, al though It does contain a species of Gümbelina. The sample was washed and examined by paleontologists of Petróleos Hexicanos, who write (freely translated) that "the fauna is poorly preserved and does not contain index fossils of any period, 
although we think that it can not be older than Cretaceous because of the presence of Gümbelina sp. However, some forms like Lamarckina, Spiroplectammina, and cibicides are present that could indicate a Paleocene age, as they are characteristic species of the Midway formation of Texas" (personal communication).

A part of the washed sample was examined by $R$. Todd, who states that Planulins correcta (Carsey)(?) "Is known from the uppermost Navarro of Texas" (Maestrichtian), yet the assemblage contains a new, unnamed genus. "to be described by $A$. R. Loeblich, Jr., (who) observed it in the Cenomanian of France and Santonian of Spain, but not heretofore on this continent.... The fauna is not similar to any with which I am familiar. It is unlike many of the faunas of the Upper Cretaceous of Mexico and the Gulf coastal area of the United States in lacking planktonic specimens, such as..... Globigerina and Globotruncana, which (w1th Gümbel1na) are to be expected in marine Upper Cretaceous sediments" (personal communication). Obviously, the particular facies of the Mexcala formation represented by this sample is different from the common facies of Upper Cretaceous marine clastic rocks of the Gulf coastal region of the United States and Mexico. Further study of the fauna of this facies is desirable, as at present it is not useful in fixing the precise age of the enclosing rocks. 
The lowermost, oldest part of the formation in the area mapped seems to be represented by sample F57-42, from the basal calcareous siltstone beds near Cacahuamilpa Oaverns. Chips examined by E. R. Applin were found to contain very sparse fauna, which consists mainly of Praeglobotruncana delrioensis (?), Gümbelina(?) sp., and Globigerina(?) sp. In regard to $P$. delrioensis $(?)$ she comments that it "is poorly defined on the slide. Bronnimann and Brown give its range as 'Albian to Cenomanian, possibly lower Turonian'. Another form which the same fossil closely resembles is Helvetoglobotruncana helvetica (BoII1) which is found in the lower Turonian of Israel.... From faunal evidence I would suggest that Iocality $557-42$ probably represents some part of Eagle Ford (Turonian) time. The Austin and younger......Cretaceous sediments of the Gulf coast.....generally contain common to abundant specimens of several specles of Globotruncana, but in the Eagle Ford, Globlgering and Gümbelina are dominant and there are relatively few specimens of Globotruncana" (personal communication). Sample F55-49 from within $15 \mathrm{~m}$. of the underlying Cuautla formation west of Cuautla was found to contain Globotruncana schneegans1 by A. R. Loeblich, Jr., who considers the sample to be of Ooniacian age. Sample F55-8I from basal beds of the Mexcala formation at $\mathrm{Km}$. 148.8 of the Amacuzac-Iguala toll road was examined by F. Bonet, who reports the presence of Gümbelina sp. and goes on to say that it 
has a singular foraminiferal fauna that is different from that known up to now in the Upper Cretaceous of Mexico (personal commumication). Sample F55-96 from basal beds of the Mexcala formation at $\mathrm{Km}$. 155.3 of the same highway was also examined by F. Bonet, who reports the presence of Pithonella ovalis, Gümbelina sp., Globlgerina sp., and calcified radiolaria and thinks that the sample is of Turonian age. The data from microfauna thus appear to indicate that the basal part of the Hexcala formation varies in age from place to place.

By way of summary, the macrofossils found in the lowermost beds of the Mexcala formation in the area mapped provide nearly incontrovertible evidence for the early Coniacian age of the enclosing sediments and further indicate that these are near the boundary of the Coniacian and Turonian stages. The microfossils, on the other hand, Give much conflicting evidence for the age of the lowermost beds. Sufficlent forms seem to be present, however, to indicate that in the western and southwestern parts of the area, as well as south of Iguala, where the Cuautla bank facies is not present, the lowermost Mexcala beds are of late Turonian age. In other words, the base of the formation varies in age from one place to another, dependins upon the proximity of the paleo-shoreline and the position of calcareous banks in Cuautla time. 
Evidence for the age of the highest part: of the Mexcala formation is much more equirocal, and in fact the youngest beds deposited in Mexcala time were later eroded and are nowhere present in the region. Merofossils were found onIy at some unknown level well up in the formation and do not prove an age younger than Conlacian. Wicrofossils give such conflicting evidence that any close age assignment is unwarranted. With the exception of two or three species of microfossils, however, the rest of the microfauna does not prove an age younger than early Senonian. Accordingly, for any age assignment younger than Santonian, the writer thinks that further evidence is indispensable.

\section{Correlation}

The nearest named formation west of the area mapped is in the Huetamo region (locality 5, pl. 3-A), where Pantoja-Alor (1957, p. 30-37) described the lial Paso formation as probably belng equivalent in age to the cuautla and Mexcala formations, but the lithology of the Mal Paso formation is more nearly like that of the latter. "The Mexcala formation has been mapped, as such, southward from Iguala to the southerm end of 1ts outcrop at the latitude of Chilpancingo (fig. I). It continues southeastward from Iguala as an unnamed unit into northeastern Guerrero and northwestern Oaxaca, where it was named the Tilantongo marl (Salas, 1949, $p$. 118-120). The latter unit rests on the Upper Petlalcingo 
Iimestone of Turonian age (Cuautla equivalent) and is overlain with angular unconformity by early Tertiary clastic rocks. Its age is considered to range from late Turonian to Santonian or Campanian time (Erben, 1956, p. 30-31). In east-central Puebla the nearest named rociss of similar Iithology to the Mexcala formation, as well as of similar age, may be the upper part of the Upper Escamela formation. North of the State of Morelos, rocks of nearly equivalent age and litholosy to those of the liexcala formation crop out in the States of México, Hidalso, and Querétaro (pI. 3-A). The same name has been retalned in southwestern Hidalgo (Segerstrom, in press), but farther north in eastern Querétaro and west-central Hidalgo, the name Méndez shale was used by Wilson and others (1955, p. 3). The extension of this latter name from southeastem San Luis Potosf, where the formation consists of a thick sequence of shale beds of mainly Maestrichtian age, is unfortunate, because the Querétaro-Hidalgo unit is older and differs in Iithology, resemblins more closely the Vexcala formation in both aspects. The unit still farther north, in southeastern San Iuis Potosf, that is equivalent in general age but not in Iithology, to the Mexcala formation is the upper part of the Xilitla group, as defined by Bodenlos and Bonet (see Bodenlos, 1956, p. 302-303). This unit is called the San Felipe formation and consists of a sequence of limestone beds. In other words, the Mexcala formation eventually 
pinches out or possibly interfingers with the San Felipe formation to the north.

\section{Balsas clastic group}

\section{Distribution and physiographic expression}

The name Balsas clastic group (Fries, 1956c) was proposed for a composite unit which comprises a large variety of local Iithologic units of variable thickness in the drainage basin of the Mexcala-Balsas River of south-central and southwestern Mexico. The group may eventualiy include several dozen distinct formations when sufficient detalled mapping has been done, but no attempt was made to separate out and define the different lithologic units for the present study. The group includes such widely diverse rocks as gypsum, fresh-water Iimestone, limestone conglomerate, volcanic conglomerate, tuffaceous sandstone, tuffaceous siltstone, and claystone, as well as volcanic breccla, tuff; and interbedded lava flows. Some units are well indurated and others show almost no induration. One characteristic feature of these diverse units is the fact that they are the oldest Tertiary rocks on the folded and eroded Cretaceous and pre-Cretaceous formations. They are in turn older than the widespread and abundant volcanic rocks that characterize the middle part of the Tertiary system in central Mexico. A third feature is their generally moderate degree of deformation in contrast to the slight defor- 
mation of the middle and late Tertiary rock units. AlI these features together give a certain unity to this rather heterogeneous group of rocks.

The Balsas clastic group crops out in many places in the area mapped. One of the largest outcrop areas is in the low, broad valley around Iguala (quad. J-2), whence it continues southward and southwestward beyond the edge of the map. Another important outcrop area appears at Taxco, whence 1t extends to the northeast (see Edwards, 1955, p. 173-179) and southwest. A third large exposure is in the Chontalcoatlán valley (quad. $\underline{F-2}$ and $\underline{G}-2$ ) west of Cacahuamilpa Caverns, and still another one forms a nearly north-south belt between Teacalco and Huajintian on the Amacuzac-Taxco highway (quad. G-3). Extensive outcrops from the group of low hills north of Puente de Ixtla (quad. G-5). Farther east, a broad irregular nearly north-south outcrop belt extends from Cerro Amarilio (quad. E-7) Bouthward to Cerro Temilpa and beyond the edge of the map. Other smaller isolated exposures occur scattered over the area mapped, resting against the Cretaceous formations. Among these, notable patches are exposed northwest of Alpuyeca (quad. $E-5$ and $E-5$ ), southwest of Tlaquiltenango (quad. $G-7$ ), west of Tehuixtla (quad. H-5), at Emiliano Zapata (quad. D-6), southeast of Tetecalita (quad. E-6), north of Oacalco (quad. D-6), southeast of San Carlos (quad. D-8), northeast of Cocoyoc (quad. D-9), west of Anenecuilco (quad. E-9), and south of Tlayecac 
(quad. F-10).

The unit continues west of Iguala in the Balsas drainage system, where several large basin-like areas are present that consist of outcrops of some hundreds of square kilometers in extent. It continues from place to place southward as far as Km. 315 of the Acapulco highway (fig. 1). It is an important formation in northeastern Guerrero to the southeast and east of Iguala, extending into Oaxaca. It also continues eastward from norelos into the state of Puebla, and small isolated patches appear north of Kexico City in the state of Hidalgo.

The physiographic expression of the group is as variable as its constituent units. The well indurated limestone conglomerate forms smooth rounded hills with far-spaced drainage lines, much like the topography on the Cuautla and Morelos formations. An example is Cerro Amarillo, in the distant center of the oblique air photograph in plate 5, which represents one extreme type of topography. The other extreme is the intricately dissected, poorly indurated silt-sand-conglomerate sequence shown beyond Puente de Ixtla in the left center of the photograph in plate 4. Somewhat similar topography appears to the right of Santa Fe in the foreground of the photograph in plate 6 , and another area of well dissected, friable beds is to the left of Acamixtla in the central part of the photograph in plate 7. Thus, the basal beds of the group, consisting dominantly 
of coarse-grained, well indurated limestone conglomerate, do not differ appreciably from the Cretaceous Iimestone units in physiographic expression, whereas the younger; upper beds composed of weakly indurated tuffaceous silt, sand, and conglomerate have well dissected topography much like that on the Mexcala formation. Accordingly the group is difficult to distinguish, on air photographs, from several other units in the region and, more often than not, can be identified only by recourse to fleld checking.

\section{Lithology and thicloness}

The Balsas clastic group comprises lithologic units as diverse as evaporite, coarse-grained conglomerate, and lava flows. The most characteristic rock type in the area mapped, though not necessarily the most voluminous, is perhaps a medium- to coarse-grained, thick-bedded to massive, moderately to well indurated limestone conglomerate with a calcareous matrix. This is the type of rock generally present at the base of the group where the underlying unit consists of a Cretaceous formation, and it has generally been called "red conglomerate". Locally, however, fragments of schist and other pre-Cretaceous rocks are present with the carbonate fragments, as for instance in the vicinity of Taxco. The conglomerate that makes up Cerro Amarillo (quad. E-7); which 1s rather typical, consists of limestone, dolomite, chert, and rare calcareous sandstone or siltstone 
eroded from the Morelos, Cuautla, and Hexcala formations, in angular to well rounded pebbles, cobbles, and boulders up to $50 \mathrm{~cm}$. or more across. The fine-grained matrix consists of sand, silt, and clay, with iron oxides and calcite as cementing agents (sample F-36-54). The overall color is dusky red to brick red, but some beds are brownish or even yellowlsh. The carbonate constituents were obviously eroded after the source beds had been broken by tectonic movements and the fractures had been healed by calcite, as shown in the photographs of the texture of a polished surface of conglomerate in plate $15-C$ and $-D$. Beds range in thicloness from $20 \mathrm{~cm}$. to more than $1 \mathrm{~m}$. , but in places the unit is so massive that bedding is difficult to distinguish in outcrop. The thickness of the limestone conglomerate varies widely in short distances laterally and reaches a maximum, in the area mapped, of about $500 \mathrm{~m}$. In the vicinity of Cerro Amarillo. Elsewhere it is thin or was never deposited.

Another widespread Iithologic unit or rocis type, which is generally stratigraphically above and jounger than the Iimestone conglomerate, consists of poorly indurated silt, sand, and clay beds, with a minor proportion of finegrained Iimestone conglomerate interbeds and a considerable tuffaceous admixture. In total volume, this unit may exceed the volume of any other unit in the Balsas group. The two most typical outcrop areas of the unit occur in the valley 
near Iguala (quad. J-2) and to the northwest of Santa Fe (quad. H-3). The unlt rests on a variable thickness of Iimestone conglomerate and could be mapped separately if so desired. It contains several interbedded basalt flows in the Santa $\mathrm{Fe}$ area. A photomicrograph of a sample from one of these flows is illustrated in plate 20-D, and others are show in plate 20-F and plate 2l-B. These flows and others are described in the appendix under sample numbers F55-21, F55-22, F55-24, F55-33, and F55-78. The patch of Balsas group rocks in the vicinity of Acamixtla (quad. H-2) also contains an interbedded lava. flow of andesitic composition near the base (Edwards, 1955, p. 176). The youngest part of this poorly indurated lithologic unit contains thin interbeds of rhyolitic tuff east and south of Cerro Amarilio (quad. E-7), as well as in the vicinity of Cerro Quebrantadero (quad. F-4). Two beds are described under sample numbers F-35-54 and F-47-54, and a photomicrograph of a thin section of one of them is depicted in plate 19-F. The beds range from thin to thick $(5 \mathrm{~cm}$. to at least $I \mathrm{m.})$ and are generally readily distinguishable in outcrop. Colors are dominantly shades of reddish brown, but they vary from yellowish to dark brow and even greenish, local$1 y$, and some rhyolite tuff interbeds are light gray to light pink. This lithologic unit is much thicker than any of the other untts of the Balsas group in the area mapped, rangins from about $800 \mathrm{~m}$. In the Iguala outcrop area, to more than 
$2000 \mathrm{~m}$. In thickness in the Santa Fe outcrop area, but it pinches out elsewhere and was never deposited over large areas.

A relatively minor lithologic unit or rock type in the Balsas group consists of gypsum of varlous degrees of purity. The sypsum forms lenticular bodies composed of a series of thin beds that interfinger with, or are contained in the fine-grained, poorly indurated clastic unit described in the preceding paragraph. One of these lenticular bodies is defined on the east by outcrops between Cocoyoc and Oaxtepec, including Cerro Coscomate (quad. D-9), by Cacalco on the north and west (quad. $\underline{\mathrm{C}}-8$ ), and by the Balsas clastic group outcrop southeast of San Carlos on the south (quad. D-8). It must continue under younger rocks to the east, north, and west for an unknown but probably short distance. Another, smaller lens occurs at Emiliano Zapata (quad. D-6) and a third, very small lens is present about $2000 \mathrm{~m}$. east of Coatetelco (quad. F-5). The purest gypsum has a dark honey color. Admixture of silica, which is partly opal and partly chalcedony (see the photomlcrograph in plate 18-F); lightens the color to light yellow or white, and admixture of silt and clay turns the gypsum greenish, reddish, or brownish. Individual beds range from a few centimeters to a meter or so in thickness, and clay or silt interbeds are present in parts of the overall lenticular bodies. Some limestone is present locally as thin interbeds. The total 
thickness of the largest body, which is near Oaxtepec, is at least $30 \mathrm{~m}$. These lenses could be mapped separately as members of the fine-grained clastic unit, if so desired, but they probably occur at different horizons from one place to another, instead of defining one stratigraphic horizon. The writer ascribes the common occurrence of gypsum in the Balsas clastic group to calclum sulfate carried by waters dissolving anhydrite beds in the lower part of the Morelos formation, where this member was exposed to erosion in anticilnes.

Another minor lithologic unit consists of freshwater limestone, which is present in the area mapped only in the low hills west and southwest of Emiliano Zapata (quad. D-6) and in another small hill south of there at San Pedro (quad. E-7). The limestone is in beds ranging generally from about 20 to $70 \mathrm{~cm}$. In thickness. It is a tough, somewhat porous rock, which ranges in color from light yellow or cream to dark yellow or light brown. The unit appears to rest on argillaceous Eypsum at the west edge of Emiliano Zapata, but farther west it is on limestone conglomerate or poorly indurated silt beds. Presumably it is much like the gypsum in stratigraphic relationships and represents a lens up in the fine-grained clastic unit of the Balsas group, above the basal limestone conglomerate unit. The total thickness remaining in the outcrop is about $60 \mathrm{~m}$. Such lenses undoubtedly occur at different horizons from place 
to place and could probably be mapped as members or formations, depending upon their thickness and extent. The total thickness of the Balsas clastic group is extremely variable from place to place, and the original maximum thickness is generally not preserved. The group was naturally deposited only in low areas adjacent to mountain ranges, owing to down-warping or down-faulting, coupled with drainage blocking, climatic change, or some other special process. Its greatest thickness thus occurs where the basement sank most deeply and the deposits were protected from later erosion. In the area mapped, the outcrop in the vicinity of Santa Fe (quad. $\mathrm{H}-4$ and $\underline{H}-3$ ) contains the thickest section of the group, including basal Iimestone conglomerate, fine-grained clastic beds, lava flows, and tuffaceous interbeds. Judging from the dip of the beds, the thickness appears to exceed $2500 \mathrm{~m}$,, but if the dip should represent foreset bedding, in part, the true vertical thickness would be somewhat less.

\section{Structure, stratigraphic relationships, and age}

The Ealsas clastic group is almost without exception everywhere inclined moderately to steeply, and horizontal. beds are extremely rare. Dips of less than $10^{\circ}$ are uncommon, and $20^{\circ}$ to $30^{\circ}$ is perhaps an average dip, with local steepening to $70^{\circ}$ or more near faults. The structure may thus be described as due to tilted fault blocks or broad 
synclinal down-warps. : Tight folds, or even folds distinguishable on an outcrop scale, were not noted in the area mapped, or elsewhere in the region for that matter. The texture of the units that make up the group has therefore not been appreciably affected by tectonic movements. Several small stocks and dikes have penetrated the group, particularly northwest and southwest of Amacuzac (quad. G-4), and these have caused marmorization and silication of the Iimestone fragments in the conglomerate beds.

The Balsas group rests with great angular and eroslonal unconformity on all the older rocks of the region, from the Upper Cretaceous Mexcala formation down to the: Paleozolc Taxco schist. The relationship is well illustrated in the structure sections in plate 2. The youngest formation older than the Balsas group (Mexcala) is the most common underlying rock in the area mapped, and each successively older formation is less common as the base on which the group rests. The next overlying formation consists of the Tilzapotla rhyolite series, which is everywhere in angular concordance with the topmost beds of the underlying Balsas group. Both the topmost beds of the Balsas group and the overlying Tilzapotla series have much flatter dips than the lower beds of the Balsas group. In places where the Tilzapotla series is absent, either by non-deposition or by erosion, the next overlying unit may be any one of the younger middie Tertiary volcanic series, the late 
Tertiary Cuernavaca formation, or even rocks of Quaternary age. In this event, the younger unit generally rests with marked angular and erosional unconformity on the Balsas group, the discordance increasing with greater age differential.

The age range of the Balsas clastic group is undoubtedly broad, but its ilmits have nowhere been fixed. A radiometric age detemination of zircon concentrated from the overlying Tilzapotla rhyolite series (sample F56-27), made by $H$. W. Jaffe and colleagues, gave 28 million years, or roughly the boundary between the Milocene and Oligocene epochs. This means that the Balsas group is certainly no younger than Oligocene in its upper part.

Calcareous fresh-water interbeds in the lower part of the Pachuca volcanic series overlying the Balsas clastic group in the Amajac River valley about $160 \mathrm{~km}$. north of the area mapped (Segerstrom, 1956, p. 15) ylelded sillcified Eyrogonites and internodes of charophytes, which were identified by R. E. Peck as probably belonging to the genus. Tectochara(?) and resembling T. tornata (Reid and Groves). Peck remarks that "the only described species that bears a close resemblance to the material from ivexico is $\underline{\text { T. tornata }}$ (Reid and Groves). This species was described from the Lower Headon beds (Iudian Eocene) of England and has been 1dentified by Nadier from the Stampian and Chattian Oligocene of central Europe. The Mexican species probably is not 
I. tornata and could be younger. This material is definitely Tertiary--probably lower Tertiary" (personal communication).

Vertebrates found in the lower beds of a thick, stratigraphically similar sequence of red conglomerate beds near Marfil in central Guanajuato ( 1 l. 3-A; Edwards, 1955 , p. 170-171) appear to be of latest Eocene or earliest 011gocene age (Fries and others, 1955, p. 23-24). Concatenating these bits of evidence leads to the conclusion that the Balsas group may range in age from late Eocene to late OI1gocene, but that the larger part of it is probably older than late Oligocene.

\section{Correlation}

Rocks similar to those here included in the Balsas clastic group crop out from place to place in the Balsas drainage basin to the west and south of the area mapped. They have been mentioned in various published and unpublished papers and reports dating from the past century up to the present decade, in which ases ranging from Triassic to Pliocene have been suggested for them, but without defining units, naming: them, or giving their precise stratigraphic relationships and possible age range. The first detailed discussion of beds belonging to the group in the area west of Iguala is that of Pantoja-Alor (1957, p. 37-42), who described both the lower and upper contacts as well as Iith- 
ologic details of the unit. He carries over the name Balsas group without proposing specific formational names for different lithologic parts. The same name is extended southward on the maps of the region between Iguala and Chilpancingo (fig. 1) by Bohnenberger-Thomas (1955, pl. 2, 3, and 4), but the group is described in detail by him in the text under the name "Lower Tertlary Continental Clastics" (op. cit. p. 36-41). In the vicinity of Chilpancingo and southward from there to the limit of their outcrop, the lower. Tertiary clastic rocks were mapped by de Cserna (프 Fries, 1956b, p. 305 and sheet 7 of the seologic map) and are also referred to as the Balsas clastic group.

In the region east and northeast of Chilpancingo, in northeastern Guerrero, rocks belonsing to what is here called the Balsas clastic sroup are included by Guzmán (1950, p. 137-140) with all the rest of the Tertiary rocks, except for a sequence of gypsum beds, in a unit called "Continental Tertiary(?)", although he mentions the name "San Higuel beds" as having been used to designate similar rocks in western Oaxaca that were studied and described by him in an unpublished report in 1946 (op. c1t., p. 137). The gypsum was originally given the name Tlaltepexi gypsum series by Salas (1949, p. 97-105) for exposures near the town of that name in southwestern Puebla near the Oaxaca-Guerrero boundary Ine, and a Late Jurassic age was ascribed to 1t. Guzmán (op. c1t., p. 134-136), however, thinks that it may be of 
Late Cretaceous or early Tertiary age in northeastern Guerrero. He mentions the presence of anhydrite as well as Eypsum in the type locality and describes certain outcrops as being well folded and totaling $800 \mathrm{~m}$. or more in thickness, quoting Salas. In northeastern Guerrero, however, he states that the unit contains clay interbeds, is not folded, and is apparently interbedded with the lower part of the Tertiary system. Erben (1956, p. 34) mentions the Tlaltepexi gypsum of northeastern Guerrero as being a member of the Hua Juapan formation (Salas, 1949, p. 120-122) and agrees with Guzmán in ascribing to it an early Tertiary age. The outcrop pattern shown by Erben (1956, fig. 10) on his map of the Olinalá-Cualac-Huamuxtitlán area of northeastern Guerrero demonstrates the post-Cretaceous age of the gypsumbearing beds in that locality. The thick sequence of folded, anhydrite-bearing beds near Tlaltepexi farther east, however, may have a different age, in the opinion of the present writer.

The principal named units in western Oaxaca and southern puebla ( $p l .3-A$ ) that are similar in Iithology and stratigraphic position to the Balsas clastic group are the Huajuapan and Yanhultián beds and the cuicatlán formation. The Hua Juapan beds (Salas, 1959, p. 120-122) consist of a basal sequence of well indurated red conglomerate beds composed of pre-Tertiary rock fragments, overlain by varicolored, poorly indurated beds of sand, silt, clay, ash of vol- 
canic origin, and interbedded breccia and fine-grained conglomerate, cemented to a varying degree by calcite. Ifneous dikes and sills cut the unit. The Yanhultián beds (op. c1t., p. 122-126) are similar to the Huajuapan beds, but they are thought to be somewhat younger because they rest in places with angular discordance on the latter unit. They are in general finer in grain size and less tuffaceous. Their outcrop area is somewhat farther east and south, in northwestern Oaxaca, in contras.t to the outcrop area of the Hua juapan unit which enters northeastern Guerrero and southern Puebla. Erben (1956, p. 33-35) reviews the information on the relationship between these two units and concludes that interfingering and facies changes are more important than straight superposition in defining the units.

The Cuicatlán formation (Barrera, 1946, p. 20-24) appears to be a similar unit farther to the east, in northern Oaxaca and southeastern Puebla. Near Tehuacán in eastcentral Puebla ( $p 1$. 3-A), north of the region in which the Gilcatlán and Yanhuitlón units crop out, a sequence of thin to thick beds of conglomerate, s1lt, sypsum, and fresh-water Iimestone has been named the Tehuacán formation (CalderónGarcía, 1956, p. 23-24) and is also considered to be of earIy Tertiary ase. This formation is actually the same as Barrera's Cuicatlán formation, however, judging from a map accompanyins Barrera's report (1946). In the descriptions of all these Tertiary units, the next overlying deposits are 
considered to be of Quaternary age. This leads one to suspect that detailed work will reveal the presence of several intermediate formations, of which only the oldest one would be equivalent to the Balsas group.

Deposits similar to those of the Balsas group have not been described to the northeast of the area mapped, but they appear to the north and northwest in the States of H1dalso, México, Querétaro, and Guanajuato (pl. 3-A), where they have been mapped and described under different names. In the vicinity of Zimapán in west-central Hidalgo, a unit of red Iimestone conglomerate beds, with interbeds of tuffaceous silt in the upper part, was described and named the El Morro fanglomerate by Simons and Mapes (1956, p. 13-16). These authors considered it to be equivalent to the Guanajuato red conglomerate farther west, and also to be of probable late Eocene and early Oligocene age. The name was extended by segerstrom (in press) to similar rocks farther east and south in the state of Hidalgo, and west into the State of Querétaro, but the unit was raised to a group called the El Morro group. Probably the best known important outcrop area of rocks equivalent to the Balsas group in central Mexico is in the Guanajuato mining district of central Guanajuato ( $\mathrm{pl}$. 3-A), where the rocks were most recently described in detail by Edwerds (1955, p. 157-172) as the Guanajuato red conglomerate, and where the unit has been dated with some precision (Fries and others, 1955, p. 23-24). 
Rocks of similar stratigraphic position and lithology were mapped and described by Flores (1920, p. 22) from the EI Oro-Tlalpujahua mining district on the Méx1co-Michoacán boundary Iine about due west of llexico City, but no name was given to the unit. Other clastic rocks with lignite and also red conglomerate are referred to by Flores (1946, p. 52) in a report that includes the Angangueo district of northwestern Michoacán.

\section{Middle Tertiary volcanic units General features}

Several units composed of volcanic rocks and interbedded clastic deposits made up largely of volcanic materlals rest on the Balsas clastic group or/and older rocks, conformably in places and unconformably in others. These units are the rilzapotla rhyolite serles, Tepoztlán formation, Zempoala andesite series, Buenavista volcanic series, and Undifferentiated volcanic series. In the descriptions that follow, the Tilzapotla rhyolite series is discussed first as being probably the oldest unit, followed by the Tepoztlán formation. The latter unit is somewhat older than the Zempoala series, which overlies it, but it may be equivalent in age to the lower part of the Buenavista and Undifferentiated series. The oldest unit (Tilzapotla) may be as old as late Oligocene, and the youngest unit (Zempoala) may be as young as early Pliocene, but the bulk of the volcanic 
rocks are believed to be dominantly of Miocene age. The volcanic units crop out principaliy in five somewhat separate areas. The northwestern corner of the map in plate $I$ is the edge of a large region of volcanic rocks that extends farther north and west. The outcrop show on the map consists of the Tepoztlán formation, at the base, overlain by the Zempoala andesite series. This is the only place where the latter unit crops out in the area mapped. The north-central part of the map contains several outcrops of the Tepoztlán formation, which is partIy buried by younger volcanic rocks. The small outcrop along the eastern border of the map; to the northeast of Cuautla, is the western edge of a much larger region of volcanic rocks, which make up the basal part of PopocatépetI Volcano and which, in the present report, have simply been called the Undifferentiated rolcanic series. The outcrops south and southwest of Tequesquitengo form the edge of a large region of such rocks that extends farther south. They consist of the Tilzapotia rhyolite series, at the base, overlain by the Buenavista volcanic series. The outcrops along the border of the map north and northeast of Taxco are also the edge of a very extensive region of such rocks. They consist of the same two series named in the preceding sentences.

The topographic expression of the volcanic units is variable from place to place, depending upon whether lava 
flows or pyroclastic beds predominate. The beds and layers in the volcanic units generally dip less than $10^{\circ}$ and are in fact nearly horizontal in large areas. "This structure impresses a blocky, stepped pattern to the areas of outcrop, the harder layers forming small cliffs where they are underlain by soft layers. The extreme left border of the photograph in plate 6 and the extreme right. border of the photograph in plate 7 give an 1dea of the type of physiosraphic expresition characteristic of large areas of volcanic rocks. The topography in the air photographs is generally distinctive and distinguishable from that developed on the rest of the rock units in the region.

The greater part of the volcanic material consists of andesite of different colors, textures, and mineral components, but some rhyolitic material occurs both near the base and near the top of the group, and even basaltic rocks occur locally in the group. The principal objective sought in mapping and naming the different volcanic series was to Group these rocks according to the volcanic centers from which they came. Erosion has been active and has removed much of the evidence needed to 'find such centers. As a result, the objective was only incompletely reached, and much more detailed petrographic studies than those carried out by the writer are required if all co-magmatic products are to be distinguished and traced out. 
The writer wishes to make a point of the fact that petrographic composition has no time significance in itself, and that nearly identical rocks were extruded at widely different times throughout the Tertiary period. Correlations can thus not be made on petrographic identity alone, and establishing a volcanic sequence in one place: will probably not help much in correlating widely separated areas; it may in fact be misleading.

\section{Tilzapotla rhyolite series}

Distribution, petrography, and thickness.--The T11zapotla rhyolite series (Fries, 1956c) was named for extensive outcrops of rhyolite tuff-breccia in the vicinity of Tilzapotla (quad. I-5) south of lake Tequesquitengo and the Amacuzac River. The outcrop extends for $8 \mathrm{~km}$. to the east of there and for about the same distance to the north, before it disappears because of erosion. It also extends some $8 \mathrm{~km}$. to the west, where it is covered by the Buenavista volcanic series, which also covers it a short distance south of Tilzapotla. In this area the unit consists of a coarse-grained, very well cemented, dark reddish brown tuff-breccla with fragments up to $30 \mathrm{~cm}$. across (sample F55-16). Bedding is extremely thick or so massive that it is difficult to distinguish in outcrop. Emptive centers for this material were probably located not more than a few kilometers away and appear to have lain to the south. Actual 
lava flows were not distinguished in the field, however, in the area covered by the map. The maximum thickness of the unit near Tilzapotla is on the order of $250 \mathrm{~m}$.

A smali erosion remnant of the Tilzapotla series appears on the east flank of Cerro Jojutla (quad. H-7), where the unit is much finer in grain size, not nearly so well cemented, and in thick but recognizable beds. Another small remnant appears $1500 \mathrm{~m}$. north of Temimilcingo (quad. F-7), also as a finer-grained tuff in beds 10 to $30 \mathrm{~cm}$. thick. Thin rhyolite tuff interbeds in the upper part of the Balsas clastic group in the valiey. east of Cerro Amarillo (quad. E-7) (sample F-35-54 and pl. 19-F) may represent fringe beds of water-borne ash at some distance from the eruptive center. A light-gray, water-deposited rhyolite tuff in upper Balsas group beds just north of the Tlaltizapán-Moyotepec highway (quad. F-7) (sample F-47-54) may also represent fringe beds around the eruptive center. Rhyolit$1 \mathrm{c}$ materlal was not found to the north or east of these latter two outcrops, but a small erosion remnant of rhyolite flows crops out just south of AcatIipa, west of Cerro Amarilio (quad. E-6).

Northwestward from Tilzapotla the rhyolite series crops out at the borders of the overlying Buenavista volcanic series, except where it is covered by the younger Cuernavaca formation or was eroded before the latter formation was deposited. The unit seems to have been deposited as 
far northwest as Cuautilta (quad. $E-4$ ), but it is very. thin or absent north of there. The grain size becomes progressively finer northwestward from Milzapotla. Near the tom of Amacuzac (quad. G-4), for example, the unit is a coarseGrained, 11ght-pink, devitrified welded tuff, and at cuautlita to the north it is a fine-grained, light-gray to pink1sh, argillaceous, water-deposited tuff in beds a few centimeters thick. The total thickness of the unit also decreases northwestward, to about $60 \mathrm{~m}$. near Amacuzac and to only a few meters near Chauchichinola to the north of there.

The unit continues as a welded tuff from Amacuzac southward and southwestward almost to Buenav1sta de Cuéllar, where it changes into bedded tuff, tuff-breccia, and interbedded lava flows. It rapidis thins out and disappears to the vest of the highnay at Santa Fe and to the south of there (quad. H-4). Extrusive vents seem to have been present a short distance north of Buenavista, and others may have been present east of there in the area now covered by the Buenavista volcanic series. At Buenavista de Cuéllar the unit turns southeastward and continues beyond the edge of the seologic map. It was not found southwest and west of the latitude of Buenavista, however, and was probably never deposited there except as a thin ashfall that was quickly removed by penecontemporaneous erosion. The unit continues westward from Amacuzac as a pink to gray welded tuff, which is almost completely devitrifled, 
to Km. 135.3 of the Amacuzac-Taxco highway, where it disappears because of removal by erosion. It picks up again farther west at the latitude of Acuitlapán (quad. G-2) and becomes much thicker toward the west, although Its character changes. Almost from Acuitlapan to Taxco the unit contains basal welded tuffs of dacitic composition, overlain by coarse-grained, dense, welded rhyolite tuff and lava flows. The thickness of the unit increases to $150 \mathrm{~m}$. or more in the vicinity of Taxco and north of there. The basal welded dacite tuff (sample F57-48; pl: 8-F. and pl. 9-C and $-E$ ) is about $20 \mathrm{~m}$. thick near $\mathrm{Km}$. 153 of the AmacuzacTaxco highway. It consists of black obsidian-like "pitchstone" which is fractured into thin, nearly vertical sheets or slabs normal to the almost horizontal attitude of the layer. A brow, devitrified, dacitic welded tuff (sample F57-49; pl. 9-B) some 4 to $6 \mathrm{~m}$. thick overlies the pitchstone in the same locality, and it is in turn overlain by a thick (more than $20 \mathrm{~m}$. ), light-pink, coarse-grained, devitrified welded rhyolite tuff (sample F57-50; pl. 8-E and pl. 9-D and $-F$ ), which extends for some unknown number of kilometers to the west.

Stratigraphic relationships, ase, and correlation.-The Tilzapotla rhyolite series generally rests concordantly upon the youngest beds of the Balsas clastic group, and in fact, thin beds of the latter group may occur locally above 
the base of the Tilzapotla unit. As a rule, however, rhyolitic volcanism was contemporaneous with cessation of sedimentation of the type represented by the Balsas group in the area mapped. The Balsas-Tilzapotla contact is nearly everywhere horizontal to slightly inclined, except locally in the vicinity of strong faults. This attitude contrasts with much steeper bedding in the lower part of the Balsas group. In places the rhyolite unit rests directly upan the Mexcala formation, and in others it is on the Cuautla and Morelos formations. Just west of $\mathrm{Km} .142 .5$ of the AmacuzacIguala highway it appears to rest upon the Xochicalco formation. In all places where the unit rests on pre-Balsas group rocks, the latter unit is missing by non-deposition and the relationship with the underlyins unit is one of angular unconformity. The Tilzapotla unit is thus transgressive, in a stratigraphic sense, in relation to the Balsas group. The terrain at the end of Ealsas time was probably of low relief, the highs having been eroded to provide the material deposited in the valieys and basins. The extrusive vents that produced the Tilzapotla rhyolite seem to have cut through the topographically and structurally high areas of that time, as rhyolite dikes were not found cutting the Balsas group.

The upper contact of the Tilzapotla unit is nearly everywhere at least an erosional disconformity. The next younger, Buenavista volcanic series covers the rhyolite con- 
cordantly south of the Amacuzac River, but where erosion has stripped off the Buenavista series, the next younger, Cuernavaca formation lies on the Tilzapotla rhyolite with erosional and, in places, angular unconformity. The Cuernavaca formation is the predominant covering unit north of the Amacuzac River. On the east side of the patch of rhyolite south of AcatIlpa (qua.d. E-6), the next younger, Chichinautzin basalt is asainst the rhyolite without the intervening Cuernavaca formation, which was probably eroded. The writer collected somewhat more than $200 \mathrm{kilo-}$ grams of frlable, light-gray to pinkish, devitrified, welded rhyolite tuff from road cuts at about $\mathrm{Km}$. 129.5 of the Amacuzac-Taxco highway and concentrated the heavy minerals by panning the sample in the stream below. The sample (F56-27) came from probably some 40 or $50 \mathrm{~m}$. above the base of the Tilzapotia series, where the underlyins unit is the Balsas clastic group. The concentrate was used by $H . W$. Jaffe and colleagues for a radiometric age determination by tine lead-alpha method, which utilizes zircon. The age reported is 28 million years, with limits of error possibly In excess of 10 per cent, according to Jaffe (personal communication). . The age thus corresponds to late Oligocene or early Miocene time, although the witer favors the older age because of the lons geologic history attested by the overlying rock units. 
Precise correlation with other volcanic units around the area mapped is not possible at the present state of knowledge regarding the ages of Tertiary volcanic rocks of central Mexico. In age, although not in lithology, the Tilzapotla unft may correspond to the basal part of the Xochitepec volcanic series of the south end of the Mexico Basin (Mooser, 1956), which is of andesitic composition. In northeastern Hidalgo, farther north (pI. 3-A), the lower part of the Pachuca group (Segerstrom, in press; Geyne, 1956, p. 49-51), which is also of andesitic composition, may correspond in age to the Tilzapotla unit. In the zimapán mining district of west-central Hidalgo, the lower part of the Las Espinas volcanic rocks (Simons and Mapes, 1956, p. 16-17) has the same relationship to the underlying El Norro fanGlomerate as the Tilzapotla rhyolite series has to the Balsas clastic group, and the age is probably also about the same, although the basal layers of the Las Espinas volcan1c unit are composed of andesite, quartz latite, and basalt, rather then of rhyolite.

\section{Tepoztián formation}

Distribution, petrosraphy, and thickness.--The Tepoztlán formation (Fries, 1956c) was named for outcrops near the tow of that name (quad. $\mathrm{c}-7$ ) about $16 \mathrm{~km}$. northeast of Guernavaca. The unit crops out for about $3 \mathrm{~km}$. both north and south of the town and continues as far east as San Agus- 
tin (quad. C-9), where it is deeply eroded and buried under basalt flows of the Pleistocene Chichinautzin series. The unit probably thins eastward, in any event, although it may still be present under, or interfinger with the Undifferentiated volcanic series north of Ocuituco (quad. D-11) at the east edge of the map in plate I. It is presumed to wedge out in the basal part of the volcanic mass topped by Popocatépetl Volcano, which lies to the northeast of Ocuituca.

The Tepoztlain formation is covered by the Chichinautzin basalt series about $3 \mathrm{~km}$. north of Tepoztlán and does not reappear farther north. Erosion has removed it south of the latitude of 0acalco (quad. $\underline{c}-8$ ), where the base is exposed, except perhaps for a small patch of simiIar volcanic material about $2000 \mathrm{~m}$. east of $\mathrm{Km}$. 51 of the Alpuyeca-Yautepec highway (quad. D-8). West of Tepoztlán the unit reappears from under the Cuernavace formation and Chichinautzin basalt series near the edfe of the geologic map (quad. C-5) and continues for 10 or $15 \mathrm{~km}$. Into the State of México, beyond the map to the northwest.

The Tepoztlán formation is made up dominantly of andesitic volcanic debris deposited in beds ranging from perhaps $50 \mathrm{~cm}$. to more than $10 \mathrm{~m}$. In thickness. Bedding is nearly horizontal in much of the outcrop area, but dips reach a maximum of about $7^{\circ} \mathrm{N}$. In the eastern part of the area. Ordóñez (1937a, p. 22-23) mentions gray andesite at 
the base of the formation and reddish-brown andesite in the highest outcrops, but these flow rocks were not seen by the writer. The topography developed on the unit is described by Ordóñez (op. cit., p. 6-18) in both ample and vivid detail, thus requiring no further word here, and erosive processes that acted upon the unit are discussed by LozanoGarcía (1953, p. 208-212).

A series of 13 specimens of different boulders in basal beds of the formation north of 0acalco (quad. C-8) is described briefly in the appendix under sample number F55-43. All the specimens consist of porphyritic andesite with orthopyroxene, clinopyroxene, and amphibole, either singly or in any combination (see photomicrographs in pl. 19-A to $-E)$. Colors of individual boulders range from I1ght gray to nearly black, but reddish, purplish, and greenish tints are also present. The overall color of the beds is medium gray in fresh exposures, and yellowish to dark brow in weathered outcrop. A sample collected from the upper part of the formation in the outcrop area northeast of Cuernavaca (F55-38) consists of medium-gray pyroxene andesite. The components that make up the beds consist of detrital and tuffaceous frasments varying in size from fine clay to boulders as large as $1 \mathrm{~m}$. across. Some beds are poorly sorted and may represent mud flows or lahars, but others contain lenses of better-sorted sand and Eravel with cross-bedding, attesting to deposition by muning water. 
Fragments in the most poorly sorted beds are angular to subangular, whereas better-sorted beds contain subrounded to rounded fragments. The material is poorly indurated and friable, but the considerable admixture of tuffaceous grains causes the beds to stand in vertical cliffs where eroded, a feature that is accentuated by interlayering of better-cemented beds. The result is the rugsed, stepped toposraphy that is so characteristic of this formation where erosion has exposed 1t.

The complete original thickness of the formation is nowhere present because of erosion of the top part, but probibly most of the thickness is still present at the north end of the outcrop. The maximum thickness of what remains, measured from the base of the unit near Oacalco to the highest outcrop north of there, is about $1000 \mathrm{~m}$. This is considerably more than the thickness of "at least $250 \mathrm{~m}$. " Given by the writer in earlier published descriptions.

Stratigraphic relationships and age.- The base of the Tepoztlán formation is exposed in only three localities: 1) east of San Andrés de la Cal (quad. (-7), 2) north of Oacalco (quad. (C-8), and 3) about $4 \mathrm{~km}$. south of Yautepec (quad. D-8). In the first locality mentioned, a small outcrop of reddish silty beds ascribed to the Balsas clastic group appears under clastic volcanic beds at the northeast edge of town, without the presence of the intervening Til- 
zapotla rhyolite series. The outcrop is only about $200 \mathrm{~m}$. long by $200 \mathrm{~m}$. wide, in the form of a triangle. The silt beds dip at a low angle to the north and the total section exposed agsregates probably less than $30 \mathrm{~m}$. In thickness. Basalt of the Chichinautzin serles buries the contact to the southwest, and a small alluvium-filled sink hides the contact to the east. The relationship is Iurther complicated east of the sink by the presence of a normal fault of unknown but probably less than $50 \mathrm{~m}$. displacement, alons which the Tepoztlán formation has been dropped down against the Cuautla Iimestone. Southeast of the fault the unit rests on the Morelos formation, without any intervening rocks.

At the Oacalco locality the Tepoztlán formation rests on beds of reddish silt with interbeds of honey-colored gypsum and reddish and greenish argillaceous gypsum containing chert and some fresh-water limestone. Aluvium and basalt hide the contact to the east and west of there. The third locality contains a small patch of what appears to be an erosion remnant of the Tepoztlán formation. The southwest contact is a fault, but the north contact is sedimentary and is between this unit and the Cuautla formation. Alluvium hides the eastern and southern contacts, but nearby outcrops susgest that the underlying rock is the basal part of the Hexcala formation.

The Tepoztlán formation was obviously deposited with great angular and erosional unconformity on Cretaceous 
units. The relationship between 1 and the Balsas group is not so clear, however, and although the latter unit was certainly eroded before deposition of Tepoztlán rocks, an angular discordance was not proved at the contact. The oldest overlying unit consists of the Zempoala andesite series, which is exposed in the northwestern corner of the map. The relationship between the two units was not studied in detail, but the contact is thought to be an erosional discordance. South of this contact, to the northwest of Cuemavaca, the overlying unit is the Cuernavaca formation, which was deposited with great erosional and small angular unconformity on the Tepoztlán beds. Elsewhere the Chichinautzin basalt series covers the unit, also with great erosional and small angular unconformity. Basalt flows buried much of the toposraphically low part of the Tepoztlán formation, leaving uncovered remnants much like islands in a sea.

The age of the Tepoztian formation is not known by direct dating. It is obviously younger then the Balsas group. It is presumably somewhat younger than the Tilzapotla rhyolite, in view of the fact that the latter unit rests on the Balsas group with little or no erosional disconformity, whereas the former has a notable erosional disconformity between it and the Balsas group. It is nevertheless a relatively old Tertiary formation, because three younger Tertiary formations cover it, each of which is sep- 
arated from the next by a significant erosional disconformity. Woreover, the Tepoztlán beds were notably tilted after deposition. Concatenating these shreds of evidence the writer thinks that the base of the Tepoztlan formation may be as old as latest 01180 cene and that deposition continued on into early Miocene time. He doubts, however, that the top of the unit is younger than early Miocene.

Origin and correlation.--The source and origin of the Tepoztlán formation have been controversial. In spite of the general northerly dip of the beds, the source area certainly lay to the north of the present outcrops, for otherwise remnants of the formation would appear in protected places farther south. Noreover, the andesite components of the clastic beds are closely similar to andesite flow rocks and interbedded breccias that crop out in the southeastern, southern, and southwestern flanks of the Mexico basin to the north (Ordóñez, 1895, p. 28-41), where the name Xochitepec volcanic series was proposed for these rocks (Mooser, 1956). Some of the Tepoztlán beds were clearly deposited by running water, as attested by sand and gravel lenses here and there, with some cross-bedding. Wiuch of the rest of the unit has rude bedding that suggests rapid deposition by torrential flood waters over an alluvial slope or "bajada". The high content of volcanic ash would have increased the competence of the water to carry heavy loads 
and would have reduced sorting of the material to a minimum. Once the material was aropped, it probably remained in place and was not repeatedly picked up and carried farther along as are stream deposits. Some of the massive beds without features suggesting deposition by running water may well have been mud flows, which may better be called lahars because of their exclusively volcanic composition. Various tuff interbeds suggest that volcanic eruptions were occurring intermittently in the region.

In short, the writer thinks that the Tepoztlán formation is the southern facles of at least a part of the Xochitepec volcanic series of the south end of the Mexico Basin. Eruptive centers were doubtlessly active while the formation was being deposited, and the voluminous extrusion of fragmental products served as an easily erodable source for the Tepoztlán beds. Piling up of the volcanic products near the centers of eruption gave the necessary slope for transport of the fragmented material by running water and in the form of lahars.

The Tepoztlán formation is probably equivalent in age to some parts of the Undifferentiated volcanic series of the area mapped and to much of the Buenavista volcanic series farther south. It may also be equivalent in age to both the Agua de Obispo and Papagayo volcanic serles south of Chilpancingo (fig. I; de Cserna in Fries, 1956b, p. 311312), as well as to the Characharando volcanic series in the 
Huetamo region of southeastern Michoacán (Iocality 5 in pl. 3-A; Pantoja-Alor, 1957, p. 43-44), and to the lower part of the Zumpinito formation of central Michoacán (Williams, 1950, p. 172-176). The basal part of the latter unit is lithologicaliy similar to the Tepoztián formation in containing many volcanic mudflows or lahars, torrential flood deposits, and interbedded ash (op. c1t., p. 173). North of the latitude of Mexico City, where the equivalent Xochitepec volcanic series occurs, volcanic rocks of similar age are named the Pachuca group in east-central Hidalgo (Segerstrom, in press) and the Las Espinas volcanic rocks in west-central Hidalgo (Simons and Mapes, 1956, p. 16-17). Elsewhere in southern Mexico, both to east and west of the area mapped, middle Tertiary volcanic rocks have generally not been studied in detail or separated into distinct formations.

\section{Buenavista volcanic series}

The Buenavista volcanic series (Fries, 1956c) was named for the thick volcanic pile that forms the high mountain mass south of the Amacuzac River and east of the highway between Amacuzac and Buenavista de Cuéllar (quad. G-4, H-4, and $I-4)$. The volcanic plle extends eastward to a few kilometers beyond the longttude of Tilzapotla, where it is transected by the south-flowing Amacuzac River, and it continues eastward again beyond the river. It extends southward 
to the latitude of Hultzuco, which lies east of Iguala

(f1g. 1). AII the volcanic rocks stratigraphically above the Tilzapotla rhyolite series in this area are included in the Buenavista unit. Other volcanic rocks included in the series lie in the high mountain mass north and northwest of Taxco, also above the Tilzapotla rhyolite, but the contact is not shom there as it lies just beyond the edge of the map.

The west border of the main Buenavista outcrop appears along the left edge of the oblique air photograph in plate 6 , and the east border of the outcrop northwest of Taxco appears along the right edge of the photograph in plate 7. The toposraphic forms on the uplands consist of rounded hills of relatively low relief, but small cliffs and topographic irregularities are present, thus contrasting with the smoother, rolling uplands developed on the Cretaceous limestone. Where the upland is strongly dissected, however, hillsides are cliffed and stepped in response to interbeding of dense lava flows, breccia layers, and friable tuff beds, but not to the extent exhibited by the Tepoztién formation.

Only the basal units of the Buenavista series were studied petrographically, and only in a small area. The first unit on top of Tilzapotla rhyolite tuff at the east edge of Amacuzac town (quad. G-4) consists of an altered, lavender flow rock of probably dacitic or quartz latitic 
composition (sample F55-19). A sample from $\mathrm{Km}$. 122 of the Amacuzac-Iguala highway, near the base of the Buenavista series, was found in thin section to consist of a darkgreenish-gray, altered andesite flow rock (sample F55-85). A lava flow from $\mathrm{Km} .130 .5$ of the same highway was found to consist of basalt (sample F55-83). Another lava flow near the base of the series, at $\mathrm{Km}$. 131.5 of the same highway, consists of a dark-gray rock of probable dacitic composition (sample F55-80). Although the units sampled vary in composition from basalt to dacite, the variation in the complete series is even greater, for rhyolitic rocks are present in the upper part, but the dominant rock type is nevertheless andesite. Interbedded with the lava flows are volcanic breccia and tuff layers, as well as water-deposited, tuffaceous clastic beds. The full thickness of the series was not measured, and in fact it nowhere remains because of erosion. Horeover, the thickest part of the serles Iles outside the area mapped. A rough estimate based on the reported altitude of the mountain mass east of Buenavista, however, suggests that the series may be on the order of $1000 \mathrm{~m}$. thick.

The Buenavista series is everywhere nearly horizontal or has low dips, most of which are due largely to inftial inclination of the flows and clastic layers. The basal layers rest without merized engular unconformity on the Tilzapotla rhyolite, but the angularity between them and 
older formation is of course marked. Angular relationships between lava flows and underlying volcanic layers are unfversaliy common, mainly as a result of the initial dip of lava flowing over eroded terrain, rather than of tectonic movements. Such an origin is thought to be true of the area mapped, where the Buenavista series generally rests on the Tilzapotla series and only locally overlaps onto the Worelos formation. In the latter case, either the Tilzapotla tuff was not deposited or 1t was eroded before the Buenavista lava was extruded. The writer saw some evidence of post-Tilzapotla and pre-Buenavista erosion, as well as intraformational disconformities within the Buenavista serles, which is nearly the rule in volcanic piles. The next overlying rock unit is the Cuernavaca formation, which generally has an angular relationship to the Buenavista series in outcrop, although most of the angularity is undoubtedly due to erosion of the older series and inftial dip of the younger formation. Late Pleistocene and Recent allumium are, of course, also present on the Buenavista rocks from place to place.

Foss1ls have not been found in the Buenavista serles to date, nor have radiometric age determinations been made. Obviously the series is little younger at the base than the underlying Tilzapotla rhyolite series. If the age of the latter is late Oligocene, then the Buenavista series may also be late Oligocene in the lower part, and the 
rest would be Miocene, but if the. Tilzapotla is brought up a little higher in the time scale, then the Buenavista may be entirely of Miocene ase. Owing to the great discordance botween the latter and the overlying Cuernavaca formation, the writer thinks that the interval of time between the two was considerable. Accordingly, the top of the Buenavista series is probably. older than early Pliocene.

The volcanic vents from which the Buenavista rocks were extruded must still be buried, for the most part, inasmuch as dikes in the older rocks are exceedingly rare. Emptive centers were probably located in the area east of Buenavista, and others were probably present northwest of Taxco. The Buenavista series is doubtlessly equivalent in its lower part to the Tepoztlín formation, and to much of the Xochitepec volcanic series in the south end of the Miexico Basin. Its upper part is probably equivalent to the Zempoala andesite series, which rests on the Tepoztlán formation. To the west, south, east, and north, the series is equivalent in age and partiy in petrography to the middle Tertiary volcanic rocks described in the section on age of the Tepoztlán formation and need not be re-described.

\section{Undifferentiated volcanic series}

The writer proposed the name Undifferentiated volcanic series (Fries, 1956c) for most of the midale Tertiary volcanic rocks not of rhyolitic composition that lie north 
of the latitude of the Amacuzac River and south of Cuernavaca, but some outcrops east of Iguala are also included. These rocks are in large part lava flows that were probably extruded from vents located under or very near to them. The largest outcrop area occurs just north of Ocuituco (quad. D-1I), the second largest outcrop lies just south of Wazatepec (quad. $\mathrm{F}-4$ ), and the third largest outcrop is at the north end of Cerro Santa Haria (quad. G-7): The first and second outcrops are made up of interbedded andesitic lava flows and clastic volcanic layers, which may in large part be quivalent in age and also in I1thology to the Tepoztlain formation, but with the addition of lava flows. The succession of layers was not studied in detall. The outcrop at the north end of Cerro Santa Marfa contains gently dipping (up to $10^{\circ}$ ) clastic beds which are different from the underlying Balsas clastic group and yet unlike any of the post-Balsas units elsewhere in the area mapped. The basal beds contain quartz and may be more closely related to the Tilzapotla formation than to the Buenavista series. At any rate, the rocks are younger than the Balsas group and older than the Cuernavaca formation.

Small outcrops of andesitic volcanic rocks occur in the northwestern flank of Tesquesquitengo polje, where they protrude through the Cuernavaca formation, but they are not shown separately on the geologic map. Similar small outcrops poke up through the Cuernavaca formation $2 \mathrm{~km}$. north 
of Xoxocotla (quad. F-6), as well as at and east of $\mathrm{km}$. 96.5 of the Cuernavaca-Amacuzac toll highway. St1ll other small outcrops (samples F-42-54 and F-43-54) are present to the north and south of Tecumán (quad. E-7), where they rest mainly on beds of the Morelos formation.

A small outcrop (not mapped separately) at the south end of Lake Tuxpan (quad. J-3; sample F55-106), consisting of olivine basalt, may rest on the Balsas group and be of middle Tertiary age. A somewhat larger outcrop, but of andesitic composition, occurs $3.5 \mathrm{~km}$. southeast of Lake Tuxpan, also on the Balsas group. Andesitic lava interbeds at Km. 169.8 of the Acapulco highway, in the cut where the highways cross, may be a part of the Balsas group or may be basal lavas of the overlying Buenatista or Undifferentiated series.

All these volcanic rocks have the same relationship to the underlying Tilzapotla rhyolite series, Balsas clastic group, and/or Cretaceous rocks, as well as to the overlying Cuernavaca formation, as the Buenavista volcanic series. They are considered to have the same age range as the latter series and may be correlated with it, as well as with the Tepoztlán formation and the Xochitepec volcanic series, as described in preceding chapters. 


\section{Zempoala andesite series}

Distribution, petrography, thickness, and age..The name Zempoala was proposed (Fries, 1956c) for the serles of andesitic rocks that crop out in the northwestern corner of the geologic map and extend for some kilometers to the northwest and north, beyond the edge of the map. The series forms some of the highest mountain crests in the region, which rise to altitudes of 3400 to $3800 \mathrm{~m}$. The high country is deeply dissected, and slopes are unusually steep and cliffed in many places, although evidence of Pleistocene glaciation is lacking south of Cerro Ajusco, except on the western flank of Popocatépetl Volcano. A rough idea of the topographic expression of the formation may be obtained from the left horizon of the oblique air photograph in plate 4, which shows the north-trending andesite range extending northward from Cerro zempoala to the left of Cerro Ajusco, which 1 tself is andesitic but somewhat younger.

The petrographic make-up of the Zempoala series was not studied in detall, although the unit was traversed from the southern contact almost to the highest peak, and also in the vicinity of the Zempoala Lakes (quad. B-5) and El Capulin (quad. A-5). Only one sample (F55-60), collected from the road cut at the state boundary between iorelos and Néxico near the Zempoala Lakes, was studied petrograph- 
ically in thin section, although many chips were examined megascopically in the field. The rock sectioned is a medlum-gray, relatively coarse-grained andesite lava flow, which in this locality is interbedded with volcanic breccia of the same composition. Exposures in the vicinity show an interstratification of volcanic breccia, lava flows, tuffaceous beds, and massive interlayers composed of poorly sorted angular volcanic fragments set in a flne-grained matrix, generally of graylsh color, which appear to represent volcanic mudflows or lahars. The series is distinguished from the underlying Tepoztlan formation, however, by the presence of a large proportion of lava interlenses. The thickness of the Zempoala series is estimated to be at least $800 \mathrm{~m}$.

The Zempoala series rests with apparent conformity on the Tepoztlán formation in the area mapped. Some erosion occurred between the two units, but evidence was not seen to suggest that it was intense or of great duration. The next overlying rock unit is the Pleistocene Chichinautzin basalt series, which accumulated over a rugged topography incised deeply into the Zempoala series. The intervening Cuernavaca formation is absent. Whether a true angular unconformity exists between the Zempoala and Chichinautzin units is not known, but in view of intervening events to be described in later chapters, this seems likely to be the case. 
The age of the Zempoala series has not been determined directly and can only be inferred from relationships with the underlying and overlying formations described in the preceding paragraph. The Tepoztlain formation is thought to be no younger than early Mlocene, and thus the Zempoala series is judged to be no older than late Miocene. The next younger formation in the region, the Cuernavaca formation, is partly derived from both the Tepoztlán formation and the Zempoala series. As it is believed to be no older than late Pliocene, the suggestion is strong that the Zempoala rocks are appreciably older and probably of late Miocene age, although they may be, in part, as young as early Pliocene.

Correlation.--The Zempoala series may be correlated with the upper part of the Buenavista series farther south, both in age and general lithology, although it lacks the rhyolitic and dacitic rocks that are common in the upper part of the Tertiary volcanic sequence of central Mexico (Ordóñez, 1900, p. 16-18), as in the upper part of the Buenavista series described in a preceding chapter, and in the southern part of Hidalgo (Segerstrom, in press). Perhaps the rhyolitic and dacitic rocks are somewhat younger than the Zempoala series, perhaps erosion has stripped them away, or perhaps they were never extruded in that area. Farther south, the unit that seems to be equivalent in age but not 
In Iithology to the Zempoala series is the Sabana Grande marl, which crops out at $\mathrm{Km}$. 192 of the Acapulco highway (fig. I). The unlt was named by Bohnenberger-Thomas (1955, p. 41-44), who thinks its age is late Hocene or early Pliocene, based upon the presence of ostracodes of the genera Cypris and Candona, gastropods of the genus Planorbis, and oogonio of Chara. Still farther south, the upper part of the Agua de Obispo volcanic series (de Cserna in Fries, 1956b, p. 311-312) may correspond to the Zempoala series. Volcanic rocks of probable age equivalence occur both east and west of the area mapped, but they have not been grouped into formations or named.

Other andesitic rocks of comparable or slightly younger age than the Zempoala series occur in Cerro Ajusco a few kllometers north of Cerro Zempoala (see pl. 4) and were named the Ajusco andesite series (Mooser, 1956), of probable early Pliocene age. East of Mexico City the high, andesitic part of the Sierra Nevada (f1g. I) has been called the Iztacch huatl andesite series ( 1 bidem); this series is partly covered by still younger basaltic extmusive rocks, which form the upper cone and crater of PopocatépetI Volcano. The Sierra de Guadalupe at the north edge of Mexico City is composed largely of dacite, which has been called the Chlquihuite dacite series (1bidem) and is believed to be of early Pliocene age. Farther north and northeast, in the State of H1dalgo, probable lower Pliocene units include 
the Cerezo rhyolite, Zumate dacite, Tezuantla formation (which contains probable early Pliocene plant remains), and Don Guinyó tuffs (Segerstrom, 1956, p. 15-16; a1so, in press).

Cuernavaca formation

Distribution, Iithology, and thickness

The Cuernavaca formation (Fries, 1956c) was named for the extensive, well exposed, easily accessible, waterlaid clastic deposits on which the city of Cuernavaca is built. The name had apparently been used in earlier private reports, for it appears on a sketch map that accompanles a geohydrologic paper published by De la O-Carreño (1951, fig. 17). The origin of the name is not given, however, and no information is included as to what the "Cuernavaca formation", as there used, actually comprises, what its upper and lower contacts are, nor what its age range may be. The name is thus not new, but the formation as used in the present report is described in some deta11. The unit crops out mainly in the drainage basin of the Amacuzac River and 1ts tributaries. Its northern border extends nearly due east from the southern base of high Nevado de Toluca Volcano 50 to $60 \mathrm{~km}$. west of Cuernavaca (f1g. 1), eastward to the southern base of Popocatépetl Volcano about $25 \mathrm{~km}$. east-northeast of Cuautla, where it enters the state of Puebla and swings northeastward. From 
the northern border the formation spreads as an interrupted blanket southward for varlable distances, burying the lower topographic features. A rough southern boundary may be drawn from the point where the Cuautla-Matamoros highway leaves the east edge of the map in figure 1, westward to the north bend in the highway, and thence westward to the junction of the Chinameca and Amacuzac Rivers. A branch belt of the formation follows the Amacuzac valley southward, but the south boundary of the principal outcrop area continues westward along a line 3 to $5 \mathrm{~km}$. south or southwest of the Amacuzac River to the Iongitude of l'etipac, and thence northwestward to the base of Nevado de Toluca Volcano. In the vast area described, perhaps one-third to one-half of the surface is covered by the Cuernavaca formation, if ground with a thin veneer of Pleistocene or Recent alluvium on top of the formation is included.

Deposits of simliar stratigraphic position, nature, and origin in the southwestern part of the area mapped, which drains southward into the Iguala and Carrizal Rivers and thence directly into the Balsas River, are also referred to the Cuernavaca formation, for convenience in the present report. If mapping were to be extended to the south, east, and west of there, however, another name would be desirable for these deposits, inasmuch as they, together with the Cuernavaca formation and other deposits to the north and east of the area mapped, have genetic relationship to the 
ancestral, Pllocene, principal drainage systems of the country.

The physiographic expression of the Cuernavaca formation is distinctive because of the youthful stage 1t represents in the erosion cycle. The unit forms gently inclined plains with a constructional surface, furrowed to a variable degree by $\mathrm{V}$-shaped or box-shaped arroyos and val= leys. Few localitieg have been sufficiently eroded to have lost the flat constructional interfluves. The oblique air photograph in plate 4 illustrates well the general nature of the topography, as the larger part of the surface area south of the mountain range on the horizon consists of outcrops of the Cuernavaca formation. The areas between the Amacuzac River and Puente de Ixtla and between there and Lake Tequesquitengo, for example, retain much of the concstructional surface of the unit. The lake occupies a polje formed after the Cuernavaca formation was deposited. Short gashes and longer canyons are eroding headward into the constructional surface. The area around Cuernavaca in the photograph mentioned is rather intricately furrowed by deep, narrow canyons, but flat interfluves are still present. In many places around the edge of the Cuemavaca formation, the constructional surface continues onto older bedrock as a destructional pediment surface. Even out in the main outcrop areas of the Cuemavaca formation, small hills have been planed off by erosion to a pediment surface at a level 
With the adjacent constructional surface. The photograph in plate 5 illustrates even better the dissection of the Cuernavaca formation by the Amacuzac and Chinameca Rivers with their short tributaries.

The constructional plains descend at angles ranging from as much as $5^{\circ}$ near the mountain fronts, to as low as $1^{\circ}$ or so in the vicinity of the main drainages. They descend from both the north and the south toward the Amacuzac River. In places where passes through mountain ridges restricted southward drainage flow, the plains are at a lower level on the downstream side of the passes. This is particularly marked between Cuautla and Moyotepec (right background of photograph in plate 5), which are on two sides of a mountain ridge with several passes through which alluvium was carried. It is even more notable on the northwest and southeast sides of the Cacahuamilpa mountain ridge, where the San Jerónimo and Chontalcoatlán drainages were restricted by a narrow pass through the Iimestone ridge. A suggestion of this latter feature is given in the northwest corner of the geologic map in sheet 2 of plate 1, although the actual pass through the limestone ridge lies several kilometers north of the edge of the map.

The Iithologic make-up of the Cuernavaca formation is extremely varied, resembling the Balsas clastic group in the variety of rock types present. Near the mountain fronts the greater part of the unit consists of moderately coarse 
grained conglomerate or fanglomerate, of which the constituents are almost exclusively andesitic volcanic rocks eroded from the Tertiary volcanic series described in earlier chapters. Ordóñez (1937a, p. 12-14) describes in considerable detall the lithology of the beds on which Cuennavaca is built. This part of the formation is similer to the Tepoztlán formation in containing beds from one to several meters in thickness, composed of poorly sorted angular to subrounded material ranging in size from fine silt to boulders as large as a meter across. Tuffaceous material is present in some beds but not in others, and sorting by water, with cross-bedding, is visible here and there. The beds thus have a laharic character, in part, and a torrential water-laid aspect, in part.

Farther from the mountain fronts the Cuernavaca formation contains thinner beds, rarely exceeding $2 \mathrm{~m}$. in thickness, and the grain size within the beds is finer, on the average, although large boulders are still present in some beds. The constituent fragments are not as angular, in general, as they are farther north. Much of the material is of relatively local origin, and the various topographtc highs that are partly buried by the formation contributed their part, which corresponds in composition to the make-up of the high points. Nevertheless, the influx of andesitic material from farther away impressed an overall volcanic composition on the formation. Beds of fine-grained con- 
glomerate, sand, and silt are more common in the lower part of the region. Small ponds must have formed locally, judgIng from limy deposits and diatomaceous earth (sample F5735) in some interbeds. One of the largest deposits of marl is just east of the Chinameca River on the highway leading from Tlaquiltenango to Huautla (quad. $\underline{-}-7$ ). Travertine deposits were formed from spring waters issuing from the IImestone and are present from place to place. The most notable large deposits are at the north edge of Tlaltizapán (sample F-32-50; pl. 18-B) and just southeast of Temilpa Vieja (quad. F-7). Even gypsum (sample F-45-54; pl. 18-D) was deposited in small ponds in the valley leading south-southeastward from Tlaltizapán (quad. G-7).

The small patches of Cuernavaca formation in the drainase area south and southeast of the Coxcatian anticline in the southwestern part of the area mapped consist of material derived locally from the weathering and erosion of the limestone or other nearby rocks. They cover an insignificantly small total area.

The thickness of the Cuernavaca formation is extremely variable from place to place, and the unit was of course not deposited over topographic highs. Exposures of at least $100 \mathrm{~m}$. of beds appear in the vicinity of Cuernavaca, without reaching the base of the formation. Detailed Information from wells is not available, although some wells certainly penetrated deeper levels than those exposed. The 
total thickness may reach 200 or $300 \mathrm{~m}$. In some places (see sections $A-A^{\prime}$ and $B-B^{\prime}$ in plate 2 ).

Stratigraphic relationships, origin, and age

The Cuernavaca formation overlies with marked erosional disconformity all the other rock units in the region. It has marked angular relationships with the Balsas clastic group and older units, and it has an obviously small angular relationship with the different middle Tertiary volcanic units. The latter relationship is accentuated, however, by the initial dips present in both the volcanic rocks and the Cuernavaca formation, and tectonic tilting of the volcanic rocks is not necessarily everywhere proved. Nevertheless, the fact that the volcanic units form topographic highs and are strongly eroded suggests that they were uplifted and tilted along faults, which at the same time produced the low areas over which the Cuernavaca formation accumulated. The next overlying unit is the Chichinautzin basalt series, which everywhere rests with erosional disconformity on the Cuernavaca formation.

The formation is thus thought to have been deposited mainly in coalescing alluvial fans on flood plains by streams arising in the high country where much relatively unconsolidated volcanic detritus was readily available to erosion by rain storms. The more massive deposits such as those near Cuernavaca were probably emplaced as lahars or volcanic mud- 
flows. Ordóñez (1937a, p. 14) earlier suggested a mudflow origin for some of this material, but without much conviction. Following the opinion of Prister (1927, p. 1-13), Ordóñez further susgested (op. c1t., p. 16) that some of the beds were deposited as glacial outwash from melting ice in the high mountain range to the north of cerro zempoala. The writer can not agree with this latter opinion, however, because evidence of glaciars on the southern slopes of the mountains north of Cuernavaca is lacking, and more specifically because the Cuernavaca beds are thought to be older than the greater part of Pleistocene time. The small lenses of marl and gJpsum were deposited in ponds produced by the shifting drainage lines and local alluvial fans. Concurrent volcanic activity may have been very strong in the Nevado de Toluca eruptive center $50 \mathrm{~km}$. north-northwest of Cuernavaca, but it was probably weak elsewhere, for otherwise tuff beds would be more abundant, and lava flows have not been found interbedded with the formation in the area mapped.

The precise age range of the Cuernavaca formation has not been established in the area mapped. The only fossil evidence for its age consists of the presence of remains of the mastodon Cuvieronimus (identified by A. R. V. Arellano in Bonet, 1956) in beds of the formation near the town of Tonatico, located about $20 \mathrm{~km}$. northwest of Cacahuamilpa, beyond the northwest edge of sheet 2 of the geologic 
map. This genus is considered to be of late Pliocene age. In view of the fact that a great erosional unconformity separates the Cuernavaca formation from the next older, Zempoala series, which is probably of late Miocene to earliest Pliocene age, and because the formation is not very thick, the writer doubts that its age extends back beyond late Pliocene time. Diatoms ldentified by $K$. Lohman in a sample (F57-35) from the top of the formation near Tlaquiltenango (quad. G-7) indicate an early Ple1stocene age.

\section{Correlation}

The Cuernavaca formation has been carried as far south as Iguala in the present report, but from there southward almost to ChIlpancingo it seems to be absent, probably because clastic material eroded from the hillsides was carried downstream into the Balsas drainage. In the vicinity of Chilpancingo (fig. I), mainly between $\mathrm{Km} .269$ and $\mathrm{Km}$. 286 of the Acapulco highway, de Cserna identified clastic deposits that appear to be equivalent in age to the cuernavaca formation and named them the chilpancingo formation (in Fries, 1956b, p. 313-314). These deposits are finegrained and lack the abundant volcanic fragments found farther north in the Cuernavaca formation. Fossil gastropods of the genus Planorbls were found in marly interbeds with ostracodes of the genus Cypris, both of which are almost certainly post-Hiocene and probably pre-Pleistocene in age. 
Deposits equivalent to the Cuernavaca formation have not been 1dentified, or at least they have not been mapped and named west of Iguala. Deposits of similar age and nature may occur southeast and east of Iguala, in northeastern Guerrero and northwestern Oaxaca, but they have not been separated from older clastic rocks or described. In southeastern and eastern Puebla, however, Calderón-García (1956, p. 31-32) separated out and named the Amatitlán and Tehuitzingo formations. He thinks that the former is of Pliocene age and that the latter, which rests conformably on 1t, may be of early Pleistocene age. These deposits or others of equivalent age and nature continue into central and northern Puebla and Tlaxcala, but they have not been mapped separately or named.

Deposits similar to those of the Cuernavaca formation in the southwestern part of the Mexico Basin were named the Tarango formation by Bryan (1948, p. 11-12, f1g. 3 ). The top of this formation is thought to correspond roughly in age to the Plio-Pleistocene boundary (Arellano, 1953, p. 181), but without precise paleontologic evidence. The name Tarango has been carried to the end of the Mexico Basin, some $100 \mathrm{~km}$. to the northeast of Mexico C1ty, and also northward down the drainage basin of the Tula River as far as its junction with the Moctezuma River at the QuerétaroHidalgo boundary line, west of the center of Hidalgo (pl. 3-A; Segerstrom, in press). In the drainage basins of the 
Amajac and Mezquitlán Rivers, in the northeastern part of Hidalgo, however, the name Atotonilco el Grande formation has been proposed for equivalent deposits (Segerstrom, in press). In the Amajac valley near Atotonilco el Grande, remains of a late Pliocene mastodon were found in the upper part of the Atotonilco formation (Segerstrom, in press). Similar deposits occur in large volume to the northwest of the area mapped, in the states of México, northern Michozcán, Guanajuato, and beyond, but they have not been mapped separately or named. Late Pliocene vertebrate remains have been recovered from them in different localities. It is interesting to note, in passing, that early Pliocene vertebrates have not been found in these beds in central Iiexico, strengthening the opinion that the deposits are mainly no older than late Pliocene.

\section{Chichinautzin basalt series}

\section{Distribution and physiographic expression}

The Chichinautzin basalt series (Fries, 1956c) was named for high Cerro Chichinautzin, a Recent basaltic volcano along the boundary line between the State of Morelos and the Distrito Federal (quad. A-7). The series was proposed for the purpose of grouping together all the numerous interbedded lava flows, tuff and breccia layers, and waterla1d clastic deposits of andesitic to basaltic composition that rest with disconformity upon the Cuernavaca formation 
and/or older units. The series makes up the high mountain range that forms the northern border of the area mapped (pl. 1 , sheet 1) and represents a segment of the Neo-volcanic Belt described in the first section of the chapter on geomorphology. Lava flows and volcanoes of the series continue northward beyond the area covered by the geologic map in plate 1 , to form the southern flank of the Mexico Basin (see sheet $I$ of geologic map in Fries, 1956b). Other flows extend in irregular tongues southward as far as the junction of the Amacuzac and Chinameca Rivers.

In the eastern half of sheet 1 of the geologic map in plate 1 , the basalt does not quite reach Cuautla. In the central part of the sheet it descends through valleys eroded in the Tepoztlán formation and on down the valley of the Yautepec River almost as far as Las Estacas (quad. $\mathbf{F}-7$ ). The longest tongue extends down the valley between Tepoztlán and Cuernavaca to Jojutla (quad. G-6), where it continues under a Recent alluvial cover down the Yautepec River valley to the junction with the Amacuzac River, and thence down the latter as a tongue a few hundred meters wide to its Junction with the Chinameca River (quad. H-6), where it ends. An 1solated basaltic volcano with a small lava field occurs $1 \mathrm{~km}$. east of the east end of section line F-F' (quad. F-8), just beyond the map.

The Chichinautzin series has distinctive topography wherever it occurs. It is characterized by extreme youthful- 
ness and scarcely shows any erosion in most of its outcrop area. The youthfulness is quite distinct from that of the Cuernavaca formation, however, as it is due to extmusion of lava flows and accumulation of cinder and scorla cones, rather than to construction of nearly flat alluvial plains. The pattern is readily distinguishable in vertical and oblique air photographs, although in plates 4 and 5 the basalt range on the horizon is so far away that cinder cones are difficult to make out. The drainage pattern on the south slope of the basalt range is incipient and poorly integrated. Clusters of arroyos are mainly expressions of large cinder cones and lava mounds, which are readily gulleyed because of steep slopes and or lack of consolidation. Drainage blocking, with resulting alluvial accumulation is another characteristic feature around the edges of the lava flows. The flows themselves generally have hummocky surfaces and many undrained depressions, which may resemble small sinks in flat Iimestone terrain. Most of the flows are of aa type and have blocky surfaces, although a few were fluid enough to produce pahoehoe surfaces.

\section{Petrography and thicleness}

By far the greater part of the Chichinautzin series consists of porphyritic olivine basalt with labradorite microlites and abundant auglte grains in a nearly holocrystalIine matrix. Detailed petrographic descriptions and chemical 
analyses of the basalt flows that make up the Pedregal de San Angel, at the south edge of Mexico Clty and only $20 \mathrm{~km}$. north of the edge of plate 1 , have been published by Schmitter (1953, p. 232-236), who classified the rock as olivine basalt with alkaline affinities. This lava is part of the Chichinautzin series and issued from Xitll Volcano only 12 $\mathrm{km}$. north of the edge of plate 1. It was extruded about 2400 years aso, according to radiometric determinations by Libby of the $\mathrm{C}^{14}$ content of charcoal buried by the lava (Arellano, 1953, p. 176), and is typical of many of the flows that make up the series. Textures are dense to highly vesicular and depend largely upon the position of the sample within the flow. Color ranges from medium gray to nearly black, except where fumarolic activity and deuteric oxidation altered the iron minerals in the matrix and imparted a rusty red color to the rock. This alteration is particularly characteristic of breccias on and around the edges of lava flows, and of scorla and coarse ash around and in extrusive vents and in cinder and scoria cones.

Less common types of lava are 1ddingsite-augite basalt, hypersthene basalt, enstatite basalt, hypersthene basaltic andesite, and hypersthene-hornblende andesite. The latter rock forms a dome-like ridge of viscous lava unaccompanied by pyroclastic material, which is followed for 5 $\mathrm{km}$. by the boundary line between the States of México and Morelos (quad. $\underline{A}-5$ and $\underline{B}-5$ ). Some of the flows of the series 
contain xenocrysts of quartz and other minerals, whlch have reaction rims of mafic minerals, but larger, lithic xenoliths are relatively uncommon. Iaras from Chlchlnautzin Volcano and near the Zemporla Lakes are generally peppered with forelgn material in small quantity. Detailed descriptions of specimens from different flows from the area mapped are given in the appendix under sample numbers $5-1-50$, F-3-50, F-4-50, F-10-50, F-87-50, F-34-54, F-50-54, F55-59, and 556-16 to 556-3I. Photomicrographs of some of these specimens are given in plate 22-A to $-F$.

The thickness of the Chichinautzin series is of course extremely variable from place to place, as a glance at the geolog1c map suggests. The th1ckest part of the serles may occur under Chlchinautzin Volcano and in that general vicinity, for one of the old najor valleys burled by the series is thought to pass beneath that locallty (see pl. 3-B). From there eastward for about $27 \mathrm{~km}$. the series must also be thick, but a ridge of middle Tertiary volcanic rocks may separate the western and eastern ends of this belt, Judging from the presence of the Tepoztlin formation at relatirely high altitudes in the north-central part of sheet $I$ of plate 1 . The eastern end of the belt is also thought to overlie an old major valley fllled by the serles (pl. 3-G), but the thickness is considerably less. Both east and west of this belt the basalt series laps against middle Tertiary volcanic rocks and pinches out, although it 
picks up agein farther east and west beyond the area mapped. Also both north and south of the thick belt the series gradually thins out and disappears. The long tongue that flowed down the Amacuzac River from 1 ts junction with the Yautepec River is about 30 or $40 \mathrm{~m}$. thick at the junction (quad. H-6) and becomes gradually thinner in the $16.5 \mathrm{~km}$. from there downstream to the junction wIth the Chinameca Rlver, where the flow ends. It probably continued a little farther but has since been eroded.

\section{Stratigraph1c relationships and age}

The Chichinautzin basalt series rests everywhere with erosional disconformity on the next older unit, the Cuernavaca formation, in the area mapped. At every point where a contact between the two units was seen, erosion had attacked the Cuernavaca formation to a variable degree, depending upon the time when the lava at that particular point was extruded. The oldest lavas of the serles are now burled, and the relationshlp between them and the cuernavaca formation 18 not known. From evidence farther north, In the State of Hidalgo (Segerstrom, in press), however, some of the oldest basaltic lavas are apparently interlayered with the upper part of the Tarango and Atotonilco el Grande formations, which are equivalent in age to the cuernavaca formation. Basaltic extrusion thus probably overlapped deposition of the Cuernavaca formation in some places 
now buried.

Angular relationships seen between bedding in the latter unit and the overlying basalt are clearly an effect of diverse inftial dips and were nowhere thought to indicate tilting of this unit before extmusion of the basalt. Intial dips in some of the ash deposits reach a maximum of $30^{\circ}$ to $35^{\circ}$, depending upon the coarseness and size distribution of the ash. Cinder cone slopes are generally nearer the lower limlt stated, whereas lava fronts may be considerably steeper, reaching $50^{\circ}$ or $60^{\circ}$ in a few places. Ash covers topographic slopes with concordance at the base, to a maximum slope of about $35^{\circ}$, but bedding flattens gradually upward in the deposit.

In the absence of the Cuernaraca formation, the Ch1chlnautzin series rests on any one of the older rock units as far down in the section as the Morelos formation, and in fact several vents out of which basalt assigned to the serles was extmuded cut through outcropping Cretaceous rocks. Examples of such vents are Cerro de las Tetillas and Cerro de Ia Corone (quad. D-7), as well as Cerro Tezontepec Grande and another volcanic cone just south of it (quad. F-6). Other basaltic volcanoes obviously came up through outcropping Tepoztlán formation and rocks of middle Tertiary volcanic series. The relationship with all these units is unconformable, and an angular unconformity of tectonlc origin is present between the basalt and the Tepoztian formation. 
The degree of discordance increases particularly with the Balsas group, and to an even greater degree wh the cretaceous rocks. The only deposits that lie on the Chichinautzin series are continental clastic beds, marl, travertine, loess, diatomeceous earth, and peat.

The full age range of the Chichinautzin serles is not known. Volcanism has occurred in historic times, and although the only preclse date of volcanic activity near the area mapped 182400 years for Xitl1 Volcano (Arellano, 1953, p. 176), located $12 \mathrm{~km}$. north of the northwest edge of the geologic map, some other vents were probably active more recently judging from the fresh, unweathered and uneroded cinder cones and lava flows. Chronicles of pre-Hispanic time are incomplete or. were destroyed, but a folklore of events relating to volcanism attests to such activity over the past several millenia. Activity may be resumed at any time in this belt and will assurediy be repeated again and again in the future. As indicated in a preceding paragraph in this section, basaltic volcanism commenced farther north before the end of deposition of the Tarango formation, presumably in late Pliocene time (Segerstrom; in press). Evidence for such an early age in the area mapped is lackIng, possibly because of burlal of the oldest lava flows, but obviously volcanism has been golng on since some time well back in the Ple1stocene epoch. Probably the oldest basaltic rocks of the Chichinautzin series exposed in the 
area mapped are in the vicinity of Cerro Tesquistle and Cerro Partido, west of Nepantla (quad. C-10), where erosion has incised deeply into the basaltic material.

\section{Correlation}

The Chichinautzin basalt series forms part of the Neo-volcanic Belt, mentioned earlier, that extends westnorthwestward to the Pacific coast and out into the Revillaglgedo Islands, as well as east-southeastward, with interruptions, to the Gulf of Mexico, where it terminates in the cluster of cones and lava flows around San Martin Volcano, just west of the north side of the Isthmus of Tehuantepec. The rocks in this belt are correlative in composition and age with those of the Chlchinautzin series of the area mapped, but their petrography has notbeendescribed in detall, except for the area around Parfcutin Volcano in central M1choacán (11g. 1), and they have not been grouped Into named units or series. The most detalled petrographic and petrologic description of the rocks in a large region of the Neo-volcan1c Belt is the one just mentioned, in central M1choacán, by W1IIlams (1950, p. 234-271), who states that "lavas of post-Zumpinito age" (post-Zempoala age of the present report) "range from ollvine-aug1te basalts through basaltic andesites to homblende and pyroxene andesites" (op. c1t., p. 259-260). The most detalled petrologic study of the lavas from the newest volcano in the Neo-volcanic 
Belt is that of Parlcutin Volcano by Wilcox (1954, p. 289347), who points out that the composition of the lava from this one volcano changed in a period of nine years from olivine basaltic andesite to orthopyroxene andesite (op. c1t., p. 289).

Rocks equivalent in composition and age to those of the Chichinautzin series are not known to occur south of the junction of the Amacuzac and Chinameca Rivers (quad. H-6), except possibly for some sporedic lava flows or volcanoes unmapped and unknown to the writer. They continue northward, however, through the D1strito Federal and into the southerm part of the State of Hidalgo. From there northward into central Hidalgo they become more sporadic and disappear (Segerstrom, in prese). The width of this belt at the longltude of the area mapped is thus about 200 km., but by far the greater volume of volcenic products was extruded in a belt only about $60 \mathrm{~km}$. Wide, of which the southern half lies in the area mapped.

Two very large volcanoes that have been active in late Plelstocene and Recent time are located in the Neovolcanic Belt not far from the area mapped. One of them 1s Nevado de Toluca or Xinantécatl Volcano, s1tuated $45 \mathrm{~km}$. due west of the northwest corner of sheet 1 of plate 1 , and the other 18 Popocatépetl Volcano situated $10 \mathrm{~km}$. east of the northeast corner of the same sheet. These two volcanoes are andesitic in composition and are distinctly larger than, 
and significantly different in general composition from the majority of basaltic and andesitic volcanoes assigned to the Chichinautzin series, in spite of the fact that they form part of the Neo-volcanlc Belt. They apparently began to empt in late Pliocene time and continued intermittentIy through Pleistocene time and into Recent time. They undoubtediy supplied much of the andesitic detritus incorporated in the Cuernavaca formation and more recent clastic deposits, some of which are described in the next chapter.

Continental clastic deposits

Definition

The continental deposits of post-Cuemavaca age that do not consist of lava flows or clnder cones are grauped together into one single unit, which is referred to simply as Continental clastic deposits. They include generally unconsolidated materials ranging from coarse angular fanglomerate to fine silt and clay, as well as minor quantities of interbedded marl, diatomaceous earth, peat, volcanic ash, loess, and travertine. Solls and callche are not here considered to be lithostratigraphic units and are accordingly not show separately from the underlying parent units. Where they occur back in the geologic column, they may or may not retain their identity and are usually considered to represent basal beds of the next overlying formation. Only materials transported and deposited through the agency of 
water and air are here mapped separately as rock unlts. Thus only those solls and callche that were transported and re-deposited were taken into account in mapping clastic deposits. Owing to the scope of the present report, with its major emphasis on pre-Recent 11thostratigraphic units and the tectonlc history registered by them, clastic deposits less than 3 or $4 \mathrm{~m}$. thick were not mapped separately.

Description of separate areas of clastic deposits

A large patch of fanglomerate, conglomerate, gravel, sand, and silt with intermixed and interbedded volcanic ash from volcanoes of the Uhichinautzin series, including PopocatépetI Volcano, appear in the northeastern corner of sheet 1 of plate 1 . This material accumulated because of repeated drainage blocking by extrusion of basaltic lavas to the west and south, and some of it is interfingered. With the lava flows. The clastic deposits rest partly upon the Xochitepec volcanic series (equivalent to the Undifferentiated volcanic series) and partiy upon the Tarango formation (equivalent to the Cuernavaca formation), as well as upon Interbedded lava flows.

The largest area covered by the Plelstocene to Recent clastic unit is a roughly triangular patch defined by Xochitlán (quad. D-II), Anenecuilco (quad. E-9), and Yautepec (quad. D-8). A tail of this patch extends southward dow the Yautepec River valley to beyond Tlaltizapán (quad. 
E-7). The material consists partly of fanglomerate and conglomerate, but probably the larger part is composed of sand, silt, and clay, with much admixed ash. Carbonaceous matter appears to be mixed w1th the clay in the area west and south of Cuautla. Travertine and marl are present in minor quantities in the area east. of Tlaltizapán. This large area of clastic material rests upon the Cuernavaca formation, the Tepoztlan formation, the Undifferentiated volcanic series, the Balsas clastic group, and the three uppermost Cretaceous formations. It also is interingered with basaltic lave flows of the Chichinautzin series and thus rests upon some of them.

The major cause of the accumulation of these depos1ts was repeated drainage blocking on the north, in the vicinity of Oaxtepec (quad. D-9), Itzamatitlán, and Yautepec (quad. D-8), as well as down the Yautepec River valley. Drainage by way of the Yautepec RIver was lower in altitude than by way of the Cuautla Rlier southeast of Ayala (quad. E-9), and much of the Cuautla area was de-watered toward Yautepec before lava flows blocked the outlet. The extent of the alluvial cover west of Cuautla was greatly enlarged by subsequent dissolution of the limestone along the east front of the IImestone ridge west of Cuautla, with consequent sinking of that area and alluvial deposition. The valleys south of Yautepec owe their alluvial cover to drainage blocking by lava near Yautepec. Alluvium in the upper part 
of the Yautepec valley is also due to lava blocking. The southem half of this valley, however, and particularly the area east of Tlalt1zapán owe thelr extensive alluvial cover to dissolution and sink formation.

Another fairly large area covered by this clastic unit extends northwestward, southeastward, and southwestward from Jojutla (quad. $\underline{G}-6$ ). The alluvium in the latter area consists mainly of gravel; sand, and silt, with much admixture of ash. It owes its presence to drainage blocking by lava flows that descended from the north and continued down the Yautepec valley to the junction of the Amacuzac River, and thence down the Amacuzac valley to the junction of the Chinameca River. Small patches of basalt protruding through the alluvial flat to the north and south of Jojutla attest to the presence of the basalt under the alIuvium. The patch of alluvium in the vicinity of Acatilpa (quad. E-6) owes its presence to drainage blocking by lava, and the same is true of all the other alluvial patches north, northeast, east, and south of there.

Alluvial deposits that accumulated because of dissolution of limestone bedrock and the formation of sinks and poljes appear in patches of various sizes in the following places: just south of Xochitepec (quad. E-6), west of Alpuyeca (quad. F-5), around Lake Rodeo (quad. E-5), in the vicinity of Lake Coatetelco (quad. F-4), in the vicinity of Cuautlita (quad. F-4), around Fuente de Ixtla and Lake 
Tequesquitengo (quad. $G-5$ ), and in the vicinity of Iguala and Iake Iuxpan (quad. $J-2$ ). Other small patches of the same origin appear here and there and can be recognized by inspecting the geologic map.

Summary of orisin of mapped clastic deposits

In summary, most of the Continental clastic deposits of Plelstocene and Recent age show on the geologic map are due to drainage blocking by lava flows of the Chlchinautzin series or to sink and polje formation by dissolution of the underlying Cretaceous carbonate rocks and anhydrite. Almost all arroyos and river valleys contain a thin veneer of alluvium that is belng transported downstream, but only in a : few places were deposits found that were thick enough to map separately (more than 3 or $4 \mathrm{~m}$. ). The region has obviously been one of active erosion since the deposition of the Cuermavaca formation, and the products have been carried out into the Balsas drainage, except for those that have been held back temporarily as described in this chapter. The situation in the liexico Basin on the north side of the range formed by the Chlchinautzin serles. has been exactly the opposite. There, drainage blocking occurred early in Pleistocene time and produced endorelc drainage, which permitted accumulation of clastic material uninterruptedly up to the present day. 
So11s, caliche, and minor unmapped Recent deposits

No attempt was made to study or classify the so1ls of the area mapped beyond making brief observations on their general character, thickness, and relationshlp to Recent volcanism. The so1ls of the Mexico Basin and some adjoinIng localities were studied from a geological-climatic point of view by Bryan (1948), in an attempt to establish a late Ple1stocene and Recent climetic chronology, and the reader is referred to that paper for a more detailed discussion of the solis of the region. Owing to the great climatic varlation from the highest to the lowest part of the area mapped, so1ls are varlable from place to place in response to altitude and precipitation. They nevertheless appear to fall generally into the classification of tschernosem, with more or less accumulation of carbonate in the B horizon. In few places have so1ls developed nomally, however, because of repeated addition of volcanic ash or loess. Such aditions are characteristic of the northerm high country, but the southem high country southwest of the Amacuzac River did not recelve significant quantities of alr-borne materials. Addition of ash and 10ess intermupted soll development and produced two or more superposed, incompletely developed profiles in many places in the northern highland of the area mapped. Glaclal outwash from Popocatépetl Volcano is incorporated in the Continental clastic unit in the 
northeastern part of the area, but slacially derived debris elsewhere consists only of admixed loess picked up largely from the Mexico Basin and incorporated in the so11. No deposits of pure loess were noted in the area mapped, although they occur on the north side of the basalt range. Taking into account the interruptions mentioned, the high country above an altitude of about $1800 \mathrm{~m}$. Is generally characterized by black topsoll (horizon A) with considerable organic or humic content. The black soll grades downward Into dark-brown to reddish-brown soll with some Ilme (horizon B) and then into lighter-colored, yellowish sub-so1l and rotten bedrock (horizon $c$ ). The total thickness of residual soll in flat areas that have been relativeiy protected from both erosion and deposition is only 1 to $3 \mathrm{~m}$. Any addition of alr-borne ash or loess increases this thickness locally. Below an altitude of $1800 \mathrm{~m}$. the soils become progressively less black and thinner, so that in the low country near the Amacuzac River the topsoil is light gray and only 1 to $3 \mathrm{~cm}$. thick, followed by light-brown to yellowish subsoll and jellowlsh rotten bedrock. The total thicloness of residual soll in flat areas of little erosion or deposition is generaliy less then $I \mathrm{~m}$. The development of high carbonate content in the B horizon is much more pronounced than at higher altitudes, and caliche or lime depos1ts are quite generally visible. 
The term caliche as here used refers to deposits of mainly calcium carbonate with minor quantities of silica and other chemical substances that form through chemical precipitation of mineral matter from vadose waters as they evaporate in soll or bedrock near or at the surface of the ground. Deposits of this type of callche are common to wldespread at altitudes lower than about $1800 \mathrm{~m}$. Where they appear at the surface of the ground in nearly flat areas, the topsoll has apparentiy been stripped away, but where they appear at the surface on hillsides, IIme-bearing waters have apparently seeped outward to the surface and have deposited their Iime content in and on the eluvial cover upon evaporating. The latter deposits grade into travertine in places where seepage is more voluminous. By far the greater quantities of caliche appear on, over, or near outcrops of Iimestone, or conglomerate bearing limestone fragments.

Calcareous callche deposits range in thickness from a few centimeters to a maximum of perhaps $10 \mathrm{~m}$. or more. In flat areas caliche is rarely more than a few centimeters thick, although it may appear as dense. Iime coatings on fracture walls and bedding planes in the upper meter or so of bedrock, where bedrock reaches the surface of the ground. Such coatings are characteristic of limestone terrain and are thinner and less common in other types of bedrock. The thickest deposits are present where alluvium has accumulated 
locally in arroyos debouching from limestone hills. In such places the Iime-laden waters seeping from the higher Iimestone country infiltrate through the alluvium and precipitate their Iime upon evaporation. Such deposits of calichelzed alluvium have been seen in rare instances to reach $30 \mathrm{~m}$. or more in thickness. Evidence points to a general recent dissolution of caliche in the area mapped, attesting to a somewhat wetter climate at present than at the time of maximum caliche deposition, but exceptions may be found in some places.

Dark-gray basaltic ash deposits are widespread over the northern part of the area, and inciplent soll development between different layers proves that emptions occurred intermittently and were separated by long, though unknown intervals of time, probably measured in hundreds of years. Remnants of a much different type of ash and lapilI1 are present in protected places in the northern part of the area mapped, under a cover of later dark-gray ash and so11. They consist of a layer of variable thickness of light-gray frothy andesitic pumice. The layer appears only sporadically in the northwesterm part of the area mapped, but remnants of $1 \mathrm{t}$ become more common and thicker toward the west, reaching several meters in thickness near the bese of Nevado de Toluca Volcano. Similar ash and lapilli appear in remnants in the northeastern part of the area mapped. These deposits become increasingly thicker eastward toward 
Popocatépetl Volcano. Both volcanoes must therefore have had intense pumice eruptions in relatively recent time, possibly within the last 10,000 years, but the Popocatépetl eruption may heve been somewhat more recent than the Xinantécati eruption. Distribution of the ash suggests that prevaling winds during the latter emiption were such as to carry the products eastward. Basalt1c eruptions have occurred more recentiy than the andesite pumice eruptions, for dark-gray basaltic ash is present on top of the lightgray lapill1.

INTRUSIVE IGNEOUS ROCKS Pre-Cretaceous dikes and sills

The oldest intrusive rocks in the area mapped occur in the Taxco district, where they cut the Taxco schist serles in the form of numerous dikes, sills, and small 1rregular bodies. The writer did not study these rocks in detall nor attempt to map them. One of the dikes appears in the road cut at about $\mathrm{km}$. 160.5 of the Taxco highway (quad. H-I), where it is partly sill-like and partly cross-cuttins with relation to the foliation of the schist. The dike was strongly deformed and faulted with the schist, susgestIng that it is at least pre-Cretaceous in age and may be as old as Paleozolc. According to Fowler and others (1948, p. 5), the intrusive bodies are less than $5 \mathrm{~m}$. thick and are not known to invade the overlying sedimentary rocks. They 
consist of dark, fine-grained igneous rocks whlch have been variously called diorite, andesite, and trap (Osborne, 1956, p. 80$)$.

Cretaceous(?) or early Tertiary(?) stocks Distribution and petrographr

Two stock-I1ke intrusive bodies of grantitic rock cut through the Xochlcalco and Morelos formations in the vicinity of Buenavista de Cuéllar. The larger stock lies southwest of the town and is at least $7 \mathrm{~km}$. long (quad: I-3), but 1ts full extent is not known because it is covered by the Tilzapotla rhyolite serles. Moreover, the contact was not completely mapped for lack of photographic coverage. Two samples of the rock (F55-91 and F55-95) were examined in thin section by $E$. Schmitter, who classified them 28 quartz diorite porphyry and granodiorite. The former was collected from the border of the mass near the northeast end of the contact shown on the geologic.map, and the other came from the border near the southwest end of the same contact. Observations in the fleld suggest that the main mass of the rock is less basic and may approach granIte in composition. The border zone shows evidence, in the form of garnet and epldote, of admixture of lime from the intruded rocks.

The smaller stock lies west of Buenavista and is nearly oval in outcrop, measuring $4 \mathrm{~km}$. by $5 \mathrm{~km}$. In minimum 
and maximum diameters. Th1s stock is here named the Coxcatlán granite, from the smell town of that name near the north border of the granite outcrop. A sample (555-86) from along the eastern contact against slightly marmorized Xochicalco formation was examined in thin section by $E$. Schmitter, who classifled it as granodiorite porphyry. Another sample (F55-94), taken from near the southern end of the same stock, was examined in section and proved to be a true granite. The intruded limestone may have contributed some Ilme to the border zone of the stock, or the earlier phase of the intrusive may have been somewhat more basic. In any event, the main mass of the rock is homogeneous in appearance and seems to consist of granite.

A third, much smaller granitic stock crops out in Cerro Colotepec (quad. E-5), where it intrudes the Xoch1calco formation, which is slightly marmorized at and near the contact. Its outcrop dimensions are $1000 \mathrm{~m}$. Iong by $400 \mathrm{~m}$. Wide. A thin section of a sample (F55-99) taken from the northern end of the stock was examined by E. Schmitter, who reports the rock to consist of quartz monzonite.

\section{Time of emplacement}

The three stocks described above are grouped together under the map symbol "TIg" and are shown in the explanation on the geologic map as being of early Tertiary age. Closer analysis of faunal and structural data after the map 
was completed, however, suggest that the stocks may have been emplaced somewhat earlier. Direct evidence for their age indicates only that the Colotepec stock was emplaced after deposition of the Xochicalco formation, and the Coxcatián and Buenavista stocks were intruded after deposition of the Morelos formation. The Buenavista stock must be of pre-T1Izapotla age, for the Tilzapotla rhyolite series lies on 1t. All three stocks occupy anticlinal areas, which are here named the Coxcatian anticline in the south, and the Colotepec anticline in the north (pl. 3-B).

The Morelos formation is somewhat thinner (about $400 \mathrm{~m}$. thick) in the vicinity of the two southerm stocks than 1t is farther north (800-900. m. thick), and particularly significant is the fact that the top of the Norelos formation at $\mathrm{Km}$. 148.8 appears to be of late Alblan age (see page 80), Instead of early Cenomanian age as elsewhere. This 18 interpreted to mean that the area was bowed up and eroded more strongly then surrounding areas before the overlying, Mexcala formation was deposited. The cuautla formation is missing at the locality, so that the time interval represented by the unconformity is greater than in much of the region. The suggestion is thus strong that the stocks were emplaced after the Morelos formation was deposited and before the overlying Mexcala. Formation began to deposit, signlfying a late Cenomanian or early Turonian age as the date of emplacement. 
Further support for such an age consists of radiometric age determinations of four widely scattered granitic bodies located south and west of the area mapped. One of these masses, the Placeres grante, is located $100 \mathrm{~km}$. due west of Iguala, just south of locality 5 in plate 3-A. The sample (F55-52) gave an of 97 million years (Fries, 1956b, p. 322). A second intrusive body, located near El ocotito and called the El Ocotito granlte, was sampled (F56-19) at $\mathrm{km} .323$ of the Acapulco highway (f1g. 1). The radiometrlc age reported is 92 million jears (op. cit., p. 319). A third granitic body, the Xaltianguis granite, was sampled (F56-20) at $\mathrm{Km}$. 360 of the Acapulco highway (f1g. 1 ) and gave an age of 94 million jears ( $1 \mathrm{bldem}$ ). The fourth intrusive body, the Acapulco granite, was sampled (F56-21) near $\mathrm{Km}$. 400 of the Acapulco highway (118. I); the age reported is also 94 million jears (1bidem). According to the Holmes-Marble time scale, these intmusive bodies were emplaced early in Late Cretaceous time. The above evidence is not conclusive, however, and these stocks may be of early Tertlary age. Evidence suggesting possible pre-Balsas age is the fact that the outcrops of Balsas group rocks lylns north, west, and south of the Coxcatlán and Buenavista stocks had their origin in the Coxcatlán anticline. Cross-cutting relationships suggest a post-folding date of intrusion. 
Tertiary dikes, sills, and stocks

Dikes, sills, and stocks intrude the Cretaceous formations, the lower Tertlary Balsas clastic group, the middle Tertiary Tilzapotla rhyolite series, and at least the lower part of the overlying Buenarista volcanic series, but none were seen to cut the Cuernavaca formation. These intrusive bodies are not related to the Chichinautzin basalt series elther petrographicaliy or spatially and must accordingly be somewhat older. Whether they are all of more or less the same age, or whether some of them are much older than others, can not be determined with certainty from field evidence alone. Some of the basic dikes in the cretaceous formations may have been intruded contemporaneously with the basic lava flows in the Balsas clestic group and may have been feeders for such flows, as well as provided volcanlc material incorporated in the Balsas group, which contains much clastic material of rolcanic origin. Those that cut the lower and middle Tertiary rock units may have been feeders for some of the upper Tertiary volcanic rocks. The intrusive bodies are not numerous and are described in somewhat more detall in the following paragraphs.

\section{Pre-Tilzapotla (?) intrusive rocks}

Probably the oldest intmisive bodies are the basic dikes that cut the Morelos and Cuautla formations in the 
north-central part of the area mapped. One of these dikes cuts the Cuautla formation north of Cerro Barriga de Plata (quad. $(-7)$ ). Two very small dikes appear east of cerro de Ia Corone (quad. D-7), where they also cut the cuautla formation. Another, larger dike cuts the Morelos formation in the west flank of Cerro Monte Negro (quad. D-7). A sample of the latter dike $(F-7-50)$ was examined in thin section and found to consist of porphyritic olivine-hypersthene basalt, the mafic minerals of which are strongly altered to nontronite(?) (pl. 2O-E). Several sill-like bodies of simllar rock appear cutting the Morelos and Cuautla formations on the ridgetop from 2000 to $4000 \mathrm{~m}$. southwest of cerro Monte Negro (quad. E-7). The largest of these bodies was sampled (F-21-54) and found in thin section to consist of diabase with olivine phenocrysts and both ortho- and clinopyroxene in the matrix; much of the mafic material is altered to nontronite( $($ ) and calcite (pl. 20-C). A similar dike cuts the Cuautla and Morelos formations about $1500 \mathrm{~m}$. south of AtIlhuagén (quad. D-8). A very thoroughly altered basic dike cuts the Mexcala formation at about $\mathrm{Km} .148 .9$ of the Amacuzac-Taxco highway.

All these highly altered basic dikes are similar to each other in the fleld and are different in petrographic character from the other Tertlary intrusive bodies and from all the 1gneous rocks of the Chichinautzin series that were sampled. They may have been intruded earlier than or nearly 
concomitantly with the accumulation of the Balsas clastic group. They are not separated from the younger basic intrusive bodies on the geologic map and in the explanation that accompanies the map.

\section{Post-Balsas intrusive rocks}

Other bas1c rocks, which are undoubtedly younger than early Tertiary inasmuch as they cut the Balsas clastic group or jounger volcanic rocks, appear in the southwestern part of the area mapped. The- iargest mass-1s a stock about $1500 \mathrm{~m}$. In diameter whose east side just reaches the highway at $\mathrm{Km} .141 .3$ of the Amacuzac-Iguala toll road. The rock cuts the Xochicalco and Morelos formations and caused slight recrystallization of the limestone along the contact. It also cuts the rhyolite of the Tilzapotla series and the basal part of the Buenavista volcanic series. A sample (F55-84) examined in thin section. was found to consist of andesite porphyry with both ortho- and clinopyroxene in a trachytic to pllotaxitic matrix with andesine microlites. The rock has a fresh appearance in hand specimen and thin section, thus differing from the older basic dike rocks. A dike-like mass of probable andesite some $20 \mathrm{~m}$. wide cuts the Mexcala formation at $\mathrm{Km} .163 .3$ of the Taxco-Iguala highway. The dike was not traced up the hillside west of the road, but a similar rock cuts the Balsas clastic group above that point (not shown on the map) and is thought to be 
an extension of 1t. In that event, the intrusion occurred after the beds of the Balsas group had been deposited. A small stock 300 or $400 \mathrm{~m}$. In diameter penetrates the Mexcala formation $800 \mathrm{~m}$. west of Azizintla (quad. G-2). The rock is fresh and appears in hand specimen to be a finegrained diorite. It, also, is thought to be of midale Tertiary age.

A stock $2500 \mathrm{~m}$. south of Teacalco (quad. G-3) penetrates the Mexcala formation, the Balsas clastic group, and the T1lzapotla rhyolite series. A sample of it (F55-26) was examined in thin section (pl. 20-A) and found to consist of highly chloritized diabase(?). The intruded rocks are slightly metamorphosed near the contact. A second, very small stock only 100 to $300 \mathrm{~m}$. across cuts limestone conglomerate of the Balsas group $1700 \mathrm{~m}$. north of $\mathrm{Km} .123$ of the Taxco highway (quad. G-4). It, too, was sampled (F5535 ) and found in thin section (pl. 20-B) to consist of highIy chloritized diabase(?). The limestone pebbles and boulders in the Balsas group beds near the contact are marmorlzed and sillcated. A third stock crops out just north of the Amacuzac-Iguala highway between $\mathrm{Km} .123$ and $\mathrm{Km} .124$ (quad. H-4 and G-4). The outcrop area seems to include mone than one intrusive rock, but the essential composition appears in hand specimen to correspond to andesite. The IImestone conglomerate at the south end of the stock is so thoroughly silicated and garnetized that it is highly resistant 
to erosion and stands up in a small butte.

A basaltic dike (sample F55-20; pl. 21-D) cuts the T1lzapotla rhyolite series at the underpass and road junction just. west of Amacuzac (quad. G-4) (not shown on the map). A series of dacitic and andesitic dikes (sample F55-107) cuts the Balsas clast1c group at and northwest of Tepecuacuilco (quad. K-3). A group of three rhyolitic dikes penetrates the Tilzapotla rhyolite series and the basal part of the Buenavista volcanic serles at and southeast of $\mathrm{Km}$. 140.I of the Amacuzac-Iguala highway. A small cut in what appears to be a large dike cutting the Tilzapotla rhyolite series at $\mathrm{Im}$. 89.2 of the Cuernavaca-Amacuzac federal highway (western one of two parallel highways; quad. E-6) was sampled (F55-62) and found in thin section to consist of andesite. The mass of rhyolite in the same locality, referred to the Milzapotla series, appears to lie over extrusive vents and contains contorted masses of flow rock as well as Ilatter-lying lava flows. A rhyolite dike about $3 \mathrm{~m}$. Wide cuts the Cuautla formation at the north end of the hill against which Emiliano Zapata is built, at a point about $1700 \mathrm{~m}$. north of the center of the tow (quad. D-6). All these small intrusive bodies are undoubtediy of mlddle to late Tertiary age and were emplaced before deposition of both the Cuernavaca formation and Chichinautzin basalt series. No other pre-Chichinautzin intmusive bodies were seen during the fleld work in the area mapped. 


\section{STRUCTURE}

General features

The broad stmactural relationshlps between the different metamorphic, sedimentary, volcanic, and 1gneous intrusive rocks in the area mapped have been mentioned briefIy in the chapters describing those rocks, as the relationshlp of each rock unit to the underlying and overlying units was reviewed. Some of the minor structural detalls within the individual units have also been described in the sections on the corresponding units. The present chapter w1Il therefore be devoted mainly to a description of regional stmuctural features that affect more than one formation or rock unit. Although these features are shown on the geologic map in plate I, they are difficult to visualize because of the great mass of stratigraphlc, topographic, and cultural minutiae shown on that map. A much simplified diaGram 1llustrating almost exclusively stmetural features Was accordingly prepared and is reproduced at a reduced scale in plate 3-B. The latter diagram gives the location, kind, and name (if any) of each structural feature. For a third dimensional view of these features, the reader is reIerred to the geologic sections in plate 2, which are reproduced at the same scale as the geologic map, or 1:100,000.

All rock units older than the Morelos formation occupy very small areas of the geologic map and jleld little 
evidence to enable one to decipher clearly any regional structural pattern older than the one lmpressed upon them after deposition of the youngest Cretaceous (Mexcala) formation. The Taxco schlst series was strongly folded to the point of producing well defined follation before the overlying units were deposited; but the writer did not study the unit in sufficient detail to work out the regional pattern of deformation, if the small outcrop area should yield enough information for such a determination. The follation in the schist seems to have an overall easterly to northeasterly trend and relatively low dips, leading one to suspect that the series may contain repeated, strongly overturned folds. Andesite dikes and quartz velns were emplaced after development of the princlpal follation, for they cut across the layers of schist. Later movement dismupted them into segments and produced marked crenulation In the schist." Rock units between the schlst and the Morelos formation indicate only that broad warping occurred to a sufficlent degree to produce disconformities and local unconformities between them, as discussed in earlier chapters on these units.

The major reglonal structural features now apparent and declpherable, then, consist of folds produced in the Cretaceous and older rocks at some time before deposition of the Balsas clast1c group, and faults produced after the period of major folding but before deposition of the Balsas 
group had terminated. Other features consist of later faults, some of which are of late Pleistocene to Recent age, and the deep crustal rift defined by the Neo-volcanic Belt. Related to the Tertiary faulting are very broad warping and tilting of segments of the upper crust. These are the structural features that wII be described in further detall in the following chapters.

\section{Folds}

\section{Description of trends and types of folds}

The most consplcuous regional structural features In the area mapped are the folds in the Cretaceous rocks. Approximate positions of the traces of axial planes of anticlines and synclines, together wh the names of the larger ones, are given in plate 3-B. The widespread Tertiary and Quaternary rock cover unfortunately prevents tracing out the full length of ali the fold axes and makes the structural picture much less complete than one would desire. The geologic make-up of the folds may be obtained by comparIng plate 3 with the geologic map in plate 1 , and the nature of the individual folds may be seen in the sections in plate 2.

Fold axes southeast of the large Jojutla fault and In the southwestern part of the area mapped trend northwesterly, whereas those in the central and northeastern parts of the area trend more nearly northerly, and the very 
large Tecumán anticline even swings north-northeasterly between Tecumán and Tepoztlán. The small anticline east of Lake Tequesquitengo trends northeasterly, and another small anticline located just west of Acultlapán, northeast of Taxco, also has a northeasterly trend.

Most of the folds are relatively short and plunge at both ends. The Tecuman anticline, with its probable extension as the Tlaltizapan anticline south of the Jojutla fault, is the most continuous structure in the area, measuring $40 \mathrm{~km}$. In exposed length and undoubtedly extending some kllometers under cover farther northward, and also beyond the map farther southward. The Coxcatián anticline in the southwestern part of the area is more than $22 \mathrm{~km}$. long, as 1t extends southeast beyond the map. The Tuxpan anticline farther south is $17 \mathrm{~km}$. long, as shown, and may continue at least as far as Taxco, in which event it would be at least $27 \mathrm{~km}$. Ions; it continues beyond the map for some distance farther southward, across the Tuxpan fault. Some of the small folds are apparently no more than 2 or $3 \mathrm{~km}$. In length.

Fold axes are characteristically curved or sinuous along the strike, and the crests of the folds rise and fall 1rregularly. In the area northeast of Tilzapotla, south of the Jojutla fault, several small antlclines die out in synclines, and small synclines die out in anticlines; both anticlines and synclines branch in places. These relation- 
ships may perhaps be ascribed equally well to an en échelon arrangement of the folds.

The great irregularity of individual folds may be best 1llustrated by describing individual structures, of which the Tecumán anticline is a good example (pl. 3-B; pl. 2, section $A-A^{\prime}$ to $G-G^{\prime}$, and $\left.I-L^{\prime}\right)$. Erosion has stripped away the entire top of this structure in 1 ts northern part. Flat overturned beds in the Cuautla formation along the overtumed westerm flank of the fold suggest that the eroded crest was nearly recumbent, whereas most of what remains in outcrop is the steeper root zone. Although the core of the fold in the root zone 18 hidden by overlying Tertlary rocks, the deep breaching of this anticline and the deep level in the Morelos formation indicated by outcrops on elther slde of the Yautepec River valley, suggest that it may consist of the easily eroded anhydrite at the base of the Morelos formation and the underlying thin-bedded Xoch1calco formation. The character of this stmucture changes southward as the fold plunges in that direction and becomes a relatively broad, normal anticine in the vicinity of Tlalt1zapán (pl. 2, section $F-F^{\prime}$ ). The uplifted part of the structure south of the Jojutla fault, shown as the Tlaltizapán anticline in sections $G-G^{\prime}$ and $I-L^{\prime}$ of plate 2 , is again a larger and tighter fold with some overturning of both limbs. Parts of this fold have inclpient fan structure (section $D-D^{\prime}$ and $I-L^{\prime}$ of $p l .2$ ), which 18 clearly 
demonstrable by tracing dips in the fleld. Overturning thus occurs both to the east and west and changes from one direction to the other along the strike of the fold. The San Gaspar syncline, with 1ts extension as the Santa Marla syncline south of the Jojutla fault, parallels the Tecuman anticline on the west. It, also, well exemplifies the irregularity of the structures in the region. Its northern part is relatively broad and overturned to the west ( $p l .2$, sections $A-A^{\prime}$ to $D-D^{\prime}$ ), but farther south it seems to become a fairly shallow, broad, normal syncline (section F-F'). Fan structure is apparent in the northern part of this syncline. South of the Jojutla fault (see section $I-I^{\prime}$ ) the Santa Marla extension of the San Gaspar syncline appears as a tight fan fold with flanks overturned in opposite directions. The outcrops in this latter area are continuous and god, so that the interpretation is $11 \mathrm{rm}-$ Iy supported by fleld evidence. Other examples of overturnIng to both east and west, as well as fan folds, are 11lustrated in the geologic sections in plate 2. Minor features of the folds have not been shown in the sections in plate 2. These minor structural detalls, together with discontinuous and sporadic outcrops, require firm stratigraphic support and areal mapping to permit one to determine the broad overall stmuctural make-up of a g18en area. Flexures in the thick-bedded Morelos and Cuautla 
formations are generaliy tightly rounded and numerous, but where thinner-bedded rocks above and below these two formations are folded, the flexures are angular or of the chevron type, wh much repeated, nearly 1soclinal folding. Even parts of the Morelos and Cuautla formations have small chevron and knee folds here and there. The internal foldIng in the Xochicalco and Mexcala formations is particularIy intricate and could not be mapped in detall. It is therefore shown in the sections in plate 2 in a diagrammtic rather than real way. In the more tightly folded synclines, small-scale thrusting on the order of centimeters to several meters is widespread in the Mexcala formation. Both 1ntense plication and abundant small-scale thrusting are characteristic of the Mexcala formation where it overlies the schist at and near Taxco, and considerable sliding of this unit occurred along the contact. Such movement may be considered as décollement on a minor scale. The major structure over the schist, however, is anticlinal, and the schist itself is thus presumed to have been further bowed up during folding of the Cretaceous rocks.

\section{Origin and age of folds}

The predominant trend of folds in the region is close to north-northrest: The one great exception to this general rule is the large Tecumán anticline, which swings around to the north-northeast in the northern half of its 
outcrop. One is tempted to assume that this anticline continues in the same direction under the Tepoztlan formation to the north border of the geologic map, where it may unite with the smaller, nearly north-trending Ayala and San Carlos anticlines, which may also continue from the south to this point, under cover of the Tepoztlan formation. These structures may die out there, to be succeeded by others trending north to north-northwest, in view of the fact that the first folds in identical rocks that appear from under the Tertiary cover to the north, near the México-Hidalgo State boundary IIne just $100 \mathrm{~km}$. due north of Cerro Otlayuca (quad. B-8), also trend north-northwest (Segerstrom, in press, geolog1c map).

The folds may thus be thought of as originating from deep subcrustal compression expressed surficially in opposing forces acting in the directions east-northeast and west-southwest. Under such conditions and in accordance with a hypothetical strain ellipso1d, shear. fractures or tear faults would be orlented about north-northeast and west-northwest, and tension fractures would be orlented nearly east-northeast. Considering that the crystalline basement has marked rellef under the rock cover of Mesozo1c age, and considering that the Cretaceous units, and especially. the Cuautla formation, are somewhat lenticular and variable in thickness from place to place, unfform folding in response to deep subcrustal compression is not to be 
expected in the surficial rocks. The irregularities in axial trends of folds are thought to be due chlefly to these highly variable factors.

The Taxco paleo-peninsula undoubtedly acted as a buttress against, around, and over which the rocks of Mesozolc age were shoved. Folding in the limesone over and around the peninsula was much less intense than elsewhere in the region, and anomalous cross structures appear to the northeast and southwest of Taxco. One is tempted to attribute the change in direction of the Tecuman anticline and adjacent San Gaspar syncline and Xiutepec anticline to the presence of another high crystaline mass in the vicinity of Cuernavaca or not far northwest of there. Such a mass could have served as a buttress causing the structures to deviate from the general trend. The presence of a cretaceous positive area in that vicinity is further suggested by the very pronounced thinning of the Cuautla formation westward, from $750 \mathrm{~m}$. near Cerro de las Tetillas (quad. D-7) to about $300 \mathrm{~m}$. In the $\mathrm{hlll}$ south of Xiuetepec (quad. D-6). The Coxcatlén and Buenavista intrusive bodies, as well as the Colotepec stock, assuming that they were emplaced in late Cenomanian or early Turonian time, acted as hard knots reducing the intensity of folding and causIng slight deviations in trends of nearby folds.

Two other factors are of significance in furthering irregular folding in the region. One of these is the rela- 
tively thin cover over the Cuautla formation at the time of folding. The Mexcala formation was at the surface when folding began, and as folds developed it was stripped away rapidly from the highs by erosion. The lack of confining pressure from a thick sedimentary cover permitted local variations in lithology to produce aberrant minor structures in the near-surface rocks. The second factor is the presence of anhydrite in the lower part of the Morelos formation. The subsurface distribution of the anhydrite is not known, since deep wells and drill holes have not been made in the region. Anhydrite 18 known to crop out near Tilzapotla (quad. I-5), however, and is known to form a thick layer at Hultzuco only $20 \mathrm{~km}$. south of there. It is thought to continue northward to Iake Tequesquitenso, thence north-northeastward to Tepoztlán, and probably nearIf eastward from there. The affect of the anhydrite upon folds in the overlying rocks must have been great, for it would have acted as a slippage layer promoting décollement and would have squeezed up into the root zones of the folds. The anomalous, overturned Tecumán anticline is thought to owe 1ts character in part to the presence of anhydrite under the Morelos limestone, and the small anomalous anticline east of Lake Tequesquitengo may also have been formed partiy in response to the anhydrite. Possibly the fan foldIng may have been intensifled partly by the moblilty of the anhydrite in the root zones of the folds. 
The age of the folds in the area mapped can not be determined within close limits from local field evidence alone. It is obvlously younger than the Mexcala formation, which appears to be no younger than Santonian or Campanian, and it is older than the Balsas clastic group, the basal part of which is thought to be of late Eocene age. The folds were deeply eroded and the Tecumen anticline had been breached almost to the present extent before the Balsas group began to deposit and fill it up, as evinced by the presence of Balsas group beds east and northeast of $\mathrm{Te}-$ cumán (quad. E-7). The folds in Morelos are a part of the great belt of folded Jurassic and Cretaceous rocks that form the Sierra Madre Orlental of Mexico, whlch extends from the Mexico-Texas border to Guatemala, end they are thought to have formed in response to the same forces in the same general interval of time.

In the coastal region of the Gulf of Mexico northeast of Morelos, where lower Tertiary marine rocks overlie Upper Cretaceous formations, Böse and Cavins (1927, p. 142) cite evidence for folding in the sierra Madre oriental in early and middle Eocene time. Further work confirmed this conclusion and is cited by Kulr (1936, p. 140) in support of a middle Eocene age for the major period of folding, adding that upper Eocene beds cover middle Eocene beds with angular unconformity. Helm (1940, p. 347) states that the main folding of the front ranges of the Slerra Madre Oriental 
In eastern San Luis Potosf (pl. 3-A) is post-Chicontepec or post-Paleocene. Whether folding commenced much earlier farther southwest is open to question, although the area at least rose above sea level before the end of Cretaceous time. The writer nevertheless also favors an early to middle Eocene age for the time of major folding in the area mapped.

\section{Faults}

Faulting was undoubtedly repeated at intervals durIng Cenozolc time, but the ages of only a few faults have been bracketed at all closely. All the faults seen are apparently of normal type, except for very smali unmapped 10cal thrusts of less than 1 or $2 \mathrm{~m}$. of displacement in the Mexcala formation. The oldest recognizable faults, excludIng any that may be present in the Taxco schlst serles and that were not studied, cut through the Cretaceous rocks but do not dislocate the Tertiary units. Spatial relationships to the Balsas group and Cretaceous rocks, as well as the decreasing dip upward in the Balsas group, suggest that these old faults were still active while the older part of the Balsas group was belng deposited. Other faults cut the Balsas group and Tertiary volcanic series, and still others cut the Cuernavaca formation and younger unconsolidated Quaternary deposits. 
Faults of pre-Balsas or early Balsas and post-Cretaceous ase

One of the old faults, here named the Tuxpan fault, is in the southwestern part of the area mapped (pl. 3-B). It trends northwesterly for about $15 \mathrm{~km}$., where it breaks up into at least three branches, which eventually become lost in the Mexcala formation. Several other faults just north of Taxco Viejo, in the same area, may belong to this fault system, and perhaps some small faults in the Taxco district itself may be part of the same system. The faults that bound the Taxco schist on the north, however, are not part of the Tuxpan system and wlll be discussed in a later paragraph. Displacement along the Tuxpan fault may be on the order of 400 to $600 \mathrm{~m}$. at the southeast end, where the Mexcala and Xochicalco formations are brought into contact, but it is less farther to the northwest and probably dies out gradually. The southern and western sides of the various faults that make up the system are downthrown.

Another old fault that cuts the Cretaceous rocks and is burled by beds of the Balsas group lies north and east of Acuitlapén (quad. G-2) and is here named the Acultlapán fault. It is complex and branching, and parts of it become lost eastward in the Mexcala formation. Considerins that the Mexcala formation is brought into contact with the Acuitlapán formation along the central part of the fault, the 
displacement may possibly exceed $1500 \mathrm{~m}$. Because of intricate folding and the lack of marker beds in the Mexcala formation, the easterly branches of the fault can not be traced with certainty. The branch that heads due east seems to continue at least to the vicinity of Teacalco and appears to cut off the ridge of Morelos limestone, on the north, from the Hexcala formation on the south, but the fault ine 1tself is covered by Tertiary formations. If the southeast-trending branch should continue beyond the point where It is shown to terminate on the map, it would represent a hinge fault with reversal of displacement, the north side being downthrown at the southeast end of the fault. Evidence for showing the fault farther southeast was lacking in the fleld, for dislocation can not be traced through the Mexcala formation, and if the fault continued farther, it would lie burled under the Balsas group.

By far the longest old fault recognized in the res... gion is what is here named the Jojutle fault, which cuts across the south-central part of the area in a northeasterIy direction. The fault line is burled under Tertiary formations along 1ts entire mapped length of $35 \mathrm{~km}$., and displacement of rock untts was not seen at any point along 1 t. Evidence for 1ts existence consists of stmuctural discordance as evinced by abrupt termination of high anticlinal rlages on the southeast side of the fault and lack of continuity of the same structures on the northeast side, which 
is downthrown probably 600 to $800 \mathrm{~m}$. The fault zone is a Iine of weakness which was followed by the Yautepec River from Tlaltizapan to its junction with the Amacuzac River. The ends of the Jojutla fault were not mapped because of lack of photographic coverage, but the suggestion is that the northeast and may intersect the Cañón de Lobos fault, described in the next paragraph.

A fourth large old fault, here named the Cañón de Iobos fault, trends northwesterly for at least $12 \mathrm{~km}$. across the Tecumán anticline, partly cutting Cretaceous rocks and partly burled under Tertiary rocks. Its northwest end branches into several diverging faults, which disappear under younger rocks, and 1ts southeast end (not mapped) may intersect the Jojutla fault southeast of Nopalera (quad. E-8). The fault can be identified in outcrop at many places in the Cretaceous formations, and at one place just east of Km. 18 of the Cuernavaca-Cuautla highway (quad. D-7), it brings the lower part of the Norelos formation into contact with the basal part of the Mexcala formation, thus cutting out $750 \mathrm{~m}$. of beds of the Cuautla formation. The entire section at that place is overturned, so that the southwest side of the fault is downthrown. The maximum displacement on the fault may thus approach $1500 \mathrm{~m}$. The downthrown block on the southwest slde of the Cañón de Lobos fault and on the northwest side of the Jojutla fault thus represents a great downfaulted wedge. 
In the overtumed western flank of the Tecuman anticline are numerous small faults with tens of meters of displacement or less, which can be recognized because they offset contacts between the Norelos, Cuautla, and Mexcala formations. They become lost in the Morelos and Mexcala formations at short distances from the contacts with the Cuautla formation because marker beds are not present to ald in recognizing any offset. All these small faults are thought to be contemporaneous w1th the Cañon de Lobos and other old pre-Balsas faults. Several small faults in the Ayala and San Carlos anticlines and the intervening Itzamatitlain syncline are also thought to be of equivalent age. Half a dozen small faults in Cerros Xiutepec and San Pedro to the south may also be old ones.

\section{Faults of post-Balsas and pre-Pleistocene age}

Most of the rest of the faults shown on the maps in plates $I$ and $3-B$ are of middle to late Tertiary age, for they cut the Balsas group or one or more of the Tertiary rock units. The most notable fault system of this younger age is the one northwest of Taxco, which partiy limits the Taxco schist and brings it into contact with rocks of the Balsas group and T1zapotla rhyolite series. Erosion had stripped away the Mexcala formation before the Balsas group was deposited, so that the throw on the faults is not as great as one might suspect from stratigraphlc offset and 
probably does not exceed $500 \mathrm{~m}$. The main fault has several branches that distribute displacement near 1ts western end, where it becomes lost in the T1lzapotla rhyolite series, and the east end becomes lost in the Morelos formetion. The north side of the main Taxco fault and all its branches is the downthrown side.

Another important fault that cuts the Tilzapotla rhyolite series brings this undt into contact with the Morelos formation along the east side of Cerro Jojutla (quad. H-7). The fault trends north-northeast for about $10 \mathrm{~km}$. Its north end is burled under Quaternary alluvium, and 1ts south end extends beyond the edge of the map for an unknown distance. A small east-weat fault southeast of Cuautlita (quad. F-4) also cuts the Tilzapotla series and is therefore no older than Miocene. A fault with some tens of meters of displacement cuts the Balsas group about $3 \mathrm{~km}$. northeast of Tecumén and is thus no older then midale Tertiary. The middle to late Tertiary faults were responsible, in large part, for the rather gentle tilting of the Tertiary volcanic units, such as expressed by the reversal of dip in the Tepoztlán formation, from south to north.

Faults of post-Pliocene ase and the Neo-Volcanic Belt

A small fault some $1700 \mathrm{~m}$. west of $\mathrm{Km}$. $15 \mathrm{l}$ of the Amacuzac-Iguala highway cuts the Cuernavaca formation and is therefore younger than the faults mentioned in preceding 
chapters. Displacements of 1 to $4 \mathrm{~m}$. are common in the Cuernavaca formation, in some of the more recent clastic deposits, and in the Chichinautzin basalt series, but no larger faults were recognized during the perlod of field work. Displacements of greater throw would be difficult to measure in the Cuernavaca formation, unless a contact with some other rock unit were present.

A singular feature in the area is the cluster of tangential faults surrounding lake Tequesquitengo. The faults are difficult to recognize on the ground, but they show up especlally well in vertical air photographs. Once they are spotted from the air, they can be picked up easily on the ground, and displacement along them is obvious in road cuts around the lake. Ihese faults are clearly younger than the Cuernavaca formation, which once formed a flat plain over the area, and they are doubtlessly due to development of the polje occupled by the lake, as the underlying Cretaceous rocks were slowly dissolved away. The lake is $36 \mathrm{~m}$. In maximum depth and has a mean depth of about 19-20 m., according to J. Alvarez, of the Comisión para el Fomento de la Piscicultura Rural (personal communication). The deepest part of the lake is just west of the center. The water is slightly brackish, and the water level is only a few meters above the level of the nearest point on the Amacuzac River to the southwest. The lake level varies only about $1 \mathrm{~m}$. during the year. 
The most consplcuous features in the region that must be related to crustal breaks are the numerous cinder cones and lava vents, although actual fault lines related to these features are buried under extrusive igneous products. The cinder cones alone number 108 in the area covered by plate 3-B, and 52 other cones lie between the north edge of this plate and the latitude of Mexico City, making a total of 160. No attempt was made to count the lava vents that had no explosive activity, but they may number several dozen or more. One can draw Iines in many different directions that connect two or more cinder cones and lava vents, but the validity of most of them as indicating crustal breaks is open to question. In the attempt to find some pattern in the seemingly heterogeneous distribution of cinder cones, the writer offers the following interpretation, which is, of course, not the only interpretation possible from the scant data at hand.

A Iine can be drawn from Cerro de las Tetillas (quad. D-7) through Cerro de la Corona and thence to the cluster of three cones west of Xiutepec (quad. D-6). A dozen or more clusters of two to four or flve cones appears in the northern part of plate $3-B$, whlch can be connected by lines nearly parallel to the Cerro de las Tetillas line, which strikes about $N .85^{\circ} \mathrm{E}$. Th1s leads one to suspect that such a direction actually defines short, en échelon surficial faults over deeper crustal breaks. Another well defined 
Ine of cones extends from the cluster near Cerro Tezontepec Grande (quad. F-6) toward the cluster at Tezoyuca (quad. E-6) and thence to the group, already mentioned, west of Xiutepec, continuing on to the horseshoe cone northeast of Cuernavaca (pI. $3-B$ ) and on to the north edge of the map. A dozen or more parallel to subparallel lines can be drawn through other groups of cones shown on the map, more or less in the direction N. $5^{\circ} \mathrm{E}$. Th1s direction may be suspected of defining another group of short, en écheion surficial faults over deep crustal breaks. A third grouping of cones seems to occur in a northeasterly direction, and more than a dozen subparallel lines can be drawn to connect them.

The three mean directions mentioned in the precedIng paragraph--N. $5^{\circ}$ E., N. $45^{\circ}$ E., and N. $85^{\circ}$ E.--may be interpreted to represent two Ines of shear and an intermediate line of teneion in a hypothetical couple of shear forces acting in an east-west direction. If this should actually be the case, then the Neo-volcanic Belt would represent a deep crustal transcurrent fault brendins nearly east-west, whth the north side moving westward and the south slde moving eastward. The relationshlps are illustrated in the diagram of a hypothetical strain ellipsold below, oriented as stated above.

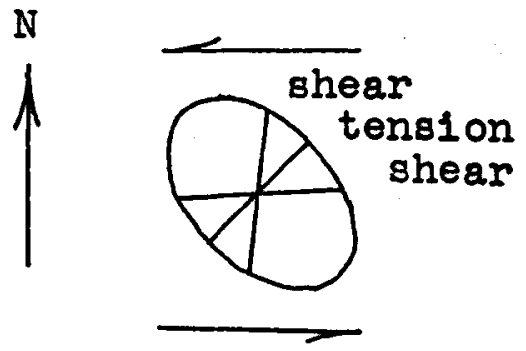


In a study of crustal deformation in the northeastern Pacific basin, Menard (1955) defined several fracture zones that roughly traverse great circle routes across the acean and into the continent. One of these, named the Clarion fracture zone for one of the volcanic islands in the Revillagigedo group off the west coast of Mexico, he traces to the Mexican mainland and equates with the Neo-volcanlc Belt (op. c1t., p. 1167-1170). He further states that the fracture zone may be followed for about $5000 \mathrm{~km}$. and appears to be from 100 to: $160 \mathrm{~km}$. Wide. Whatever transcurrent movement occurs along it is considered to be left lateral (p. 1170), which is the same as that shown in the diagram above. Menard prefers a deep convection current or 1gin for the fracture zones and thinks of the zones as welts that rise somewhat above the adjacent ocean floor (p. 1182).

\section{GEOLOGIC HISTORY}

The first event recorded in the region mapped consists of deposition of the rhyolitic tuffs and interbedded clastic deposits that make up the Taxco schist series. These rocks accumulated at some unknown date, probably late In Paleozolc time, and were subsequently folded strongly Into apparently 1soclinal and overtunned folds with northeasterly trend. Low-grade dynamic metamorphism to sericite and chlorite schist and development of strong follation seem to have accompanied folding. Faults ruptured the schist, 
quartz veinlets were formed, and andesitic dikes were emplaced. A lons period of erosion then followed these events. Over the eroded schist were deposited andesitic rocks of the Taxco Viejo green volcanic series, probably in Late Triassic time. The region may have been below sea level while at least a part of these green andesitic rocks were accumulating, judging from the calcareous matrix of some tuff interbeds. The greenstone appears to have been folded and weakly metamorphosed, with development of slight follation, before the argiliaceous and calcareous beds of the overlying Acahuizotla formation were deposited on them, probably in Late Jurassic time. The latter formation rests partly on the Taxco Viejo greenstone and partly on the Taxco schist; other units that intervene farther east are not present in the area mapped.

At least some minor folding or warping must have occurred after deposition of the Acahuizotla formation, for it remains in places protected from erosion only here and there under the next overlying formation, which consists of shale and siltstone of the Acuitlapen formation, of probable Neocomlan (Early Cretaceous) age. These two rock units show the effect of weak dynamic metamorphism to slate and phylI1te, possibly in response to post-Cretaceous deformation under a thick sedimentary cover. Phyllitic shale of the Acultlapán formation passes upward into the Xochicalco Iimestone, of Aptian-Barremian age, w1thout apparent uncon- 
formity in a part of the area. In fact, some interbedding of Ilmestone and shale occur near the contact of these two formations in the exposure along the southwest flank of Cerro Acuitlapán (quad. G-2).

A hiatus of unknown but considerable length separates the Xoch1calco Iimestone from the overlying Morelos formation, of midale Albian to early Cenomanian age. The basal beds of the latter formation consist of anhydrite in the eastern part of the area, and of limestone and/or dolomite in the rest of the area. Relief on the pre-Morelos surface was considerable and the formation did not completely cover the Taxco paleo-peninsula, which seems to have risen further between Xochicalco and Morelos time. Subsidence must have been irregular, permitting accumulation of as much as $900 \mathrm{~m}$. of limestone and dolomite in central Morelos. Most of the formation represents a relatively shallow water facies, Judging from the rudistid, gastropod, pelecypod, and foraminiferal content, and probably most of the formation in the area mapped was deposited in calcareous banks that lay east of a landmass some kllometers west of the edge of the geologic map in plate 1. W1despread dolomitization in this formation is thought to have been a diagenetic process and not due to precipitation of dolomite per se.

Near the middle of Cenomanian time the region rose from the sea and several granitic stocks (Buenavista, Cox- 
catlán, and Colotepec) seem to have been emplaced, accompanied by warping or doming and differential erosion of the top of the Morelos formation. A hiatus of some unknown length of time, but probably at least until eariy Turonian time, separates the eroded Morelos formation from the overIying basal calcarenite and limestone beds of the cuautla formation. The latter formation seems to have begun to deposit early in Turonian time and to have continued to deposit until the end of that age. A long calcareous bank formed offshore east of a landmass which, at that time, lay near the west edge of the geologic map. The western margin of the bank extends from the vicinity of Cuernavaca almost due north to the México-Hidalgo State boundary I1ne, $100 \mathrm{~km}$. north of the edge of the geologic map in plate 1 , and from Cuemavaca southward to Lake Tequesquitengo and on to the vicinity of Huitzuco, some $20 \mathrm{~km}$. beyond Tilzapotla at the south edge of the geologic map. The eastern margin of this bank lies beyond the limit of the map east of Tlayecac (quad. E-10). West of the bank the Cuautla formation is thin and consists of thin-bedded clastic calcarenite with an argiliaceous admixture.

In latest Turonian time a change in sedimentation occurred that interrupted accumulation of I1mestone and initiated deposition of mud, silt, sand, and fine-grained conglomerate, whlch form the Mexcala formation. Probable folding, uplift, and volcanism at considerable distance west 
and south of Morelos, beginning in late Cenomanian time and continuing through Turonian time, became manlfest through influx of this clastic materlal on top of the Cuautla limestone, to a total thickness of more than $1200 \mathrm{~m}$. Most of the Mexcala formation is clearly of marine origin, although the continental origin of some of the uppermost beds is not jet excluded by field evidence. The date when Mexcala deposition ceased in response to uplift of the region is not known, but it may have been no younger than Santonian or early Campanian time.

From some time late in the Late Cretaceous epoch the region wes exposed. to subaerial erosion and was not again submerged. Intense deformation of Cretaceous and earlier rocks occurred probably in early to middle Eocene time, as a southern counterpart of the Laramide deformation farther north. Erosion was greatly intensified over the anticlines and drainage was exorelc until at least late in Eocene time, when broad warping and block laulting produced endoreic drainage and consequent accumulation of enormous quantities of clastic deposits ranging from coarse conglomerate to Iine mud and even local Iimestone and gypsum interbeds, whlch are represented by the Balsas clastic group. Basic volcanism occurred simultaneously with block faulting and deposition of clastic material, adding lava flows, volcanic breccia, and tuffaceous materials to debris eroded from Cretaceous and older rocks. Fault displacements of over 
$2000 \mathrm{~m}$. seem to have occurred in different places. Act1ve faulting gradually died out in early oligocene time and brought deposition of the Balsas group to a halt. Such strong fault deformation seems not to have been repeated In Morelos since that time, for the youngest beds of the Balsas group (those overlain by the next younger, T1lzapot1a rhyolite series) are only slightly tilted and none of the higher Tertiary units have steep dips.

As deposition of the Balsas clastic group waned, rhyolitic volcanism broke out in late Oligocene time in the south-central and western parts of the region, producing the Tilzapotla series of rhyolite, including tuff, breccla, and lava flows. Rhyolitic volcanism was followed by extrusion of andesitic tuff, breccia, and lava flows in the same region, to form the Buenavista and Undifferentiated volcanic series in Miocene time. Eruptions did not consist of andesite alone, but included basalt, daclte, and even rhyolite in the upper part of the sequence. Along the northern border of the area and on Into what is now the Mexico Basin, extrusion of andesitic rocks occurred simultaneously with extrusion of the Buenarista series in probably latest Oligocene and most of lilocene time, causing accumulation of the Tepoztian formation along the southern fringe of the eruptive centers. Andesitic and dacitic volcanism continued through Mlocene time and possibly into early Pliocene time, the Zemporla andesite series being somewhat young- 
er than the Tepoztlén formation.

Faulting was renewed after accumulation of the Miocene intermediate volcanic rocks and before the continental clastic deposits of the Cuernavaca formation were laid down in late Pliocene to earliest Pleistocene time. It may, in fact, have been a major cause for accumulation of the latter formation, although large volumes of andesitic material emupted from Nevado de Toluca and Popocatépetl volcanic centers, probably in late Pliocene time, contributed much of the present content of this formation. Volcantsm may thus have been a contributing cause, and change to a drier climate may have been yet another important cause. Wuch of the central part of the area was Inundated by clastic deposits of the Cuernavaca formation, which burled much of the older topography. Broad, gently sloping plains were formed, out of which hills of older rocks rose like islands in a sea, and pedimentation further increased the flat areas here and there. Drainage from both the present Mexico Basin and the upper headwater part of the Lerma River is thought to have emptied southward into the Amacuzac River while the Cuernavaca formation was accumulating.

The exact cause for the halt in deposition of the Cuernavaca formation is not known, but three factors are believed to have intervened. Active andesitic volcanism in the Nevado de Toluca and Popocatépetl eruptive centers 
may have diminlshed greatly, while rainfall increased with the advent of the Pleistocene ice age, and basaltic volcan1sm closed off drainage from the present Mexico Baisin and upper Lerma valley. In anj event, deposition of the formation ceased and erosion commenced in early Plelstocene time. Extrusion of lavas of the Chlchinautzin basalt series must have been inftiated by development in latest Pliocene time, and particularly through Plelstocene time, of the deep transcurrent crustal faults that define the Neo-volcanic Belt, which crosses Mexico in a direction close to N. $80^{\circ} \mathrm{W}$. Surficlal rocks over the deep east-west faults were broken into blocks by shear and tension in three major directions, which are roughly north, northeast, and east, thus permitting subcrustal basaltic magma to issue from many points in a belt as wide as $200 \mathrm{~km}$. In a north-south direction, but confined mainly to about $60 \mathrm{~km}$. In width in the region here discussed. Apart from basaltic volcanism and 1ts contribution of lava and ash to the region, erosion was the main process acting through Pleistocene time south of the Neovolcanic Belt. Loess Irom glacial outwash in the Mexico Basin, andesite pum1ce from Nevado de Toluca and PopocatépetI Volcanoes, and basaltic ash from the nearby small volcanoes accumulated in protected places while soll was formIng In latest Plelstocene and Recent time.

Late Plelstocene dissolution of the Cretaceous carbonate rocks and anhydrite caused development of many sinks 
and poljes, most of which are dry but a few of which contain lakes, such as Rodeo, Coatetelco, Tequesquitengo, and Tuxpan. The poljes arrested transport of alluvium out of the region and, together with drainage blocking by basaltic lava, account for most of the thick alluvial accumulations of late Pleistocene and Recent time. These two factors set the stage for growth of the large centers of population and agricultural production in this region. Intermittent volcanism and sink formation are going on at present and are Iikely to continue into the unforeseeable future.

\section{MINERAI RESOURCES}

The principal metalilc mineral resources of the region described in this report consist of lead, zinc, silver, and gold deposits in the Taxco mining district (Fowler and others, 1948, p. 7-12; Osborne, 1956, p. 82-88). The ore minerals are in veins fliling fractures in the Taxco schist (EI Pedregal mine), the Morelos Iimestone (La Concha-San Antonio mine), and the Mexcala clastic beds (Jesús mine). Weak mineralization reached the lower part of the overlying Tertiary Balsas group, indicating that it is of Oligocene or younger age. Both limestone and shale are replaced by ore in places along the veins, and the schist is replaced to a minor degree. The metallized veins occupy fractures and faults with preferred northwest and north strikes, but some velns are orlented almost west. 
Vein fliling is variable in mineralogic make-up and in the proportion of different minerals present. Quartz predominates in the gangue, although calcite becomes predominant in veins that traverse limestone. Mixed with gangue minerals are principally pyrite, sphalerite, galena, and chalcopyrite, with very small quantities of acanthite, pyrargyrite, and other rarer silver minerals. Zinc predominates in some deposits, whereas lead is the chief metal in other veins, and silver or gold is the main metal in a few veins. Later-deposited minerals include specular hematite, fluorite, and barite in some velns. A replacement deposit in the area of the Babilonia group of veins, southeast of Taxco, consists of hardened shale with magnetite, hematite; 1Ivaite, and actinolite, together with scarce pyrite, sphalerite, and galena (Fowler and others, 1948, p. 10-11). The sulfides seem to be later than the other minerals.

Northeast of Taxco is a zone of fluorite mineral1zat1on. The largest deposit, known as La Azul, is located $900 \mathrm{~m}$. east of $\mathrm{Km} .151$ of the Taxco highway (Foshag and others, 1946; Osborne, 1956, p. 88-89; Fernández, 1956). The mineralized zone continues about $6 \mathrm{~km}$. to the northnortheast, crossing the highway at $\mathrm{Km}$. 149, and several mines have been opened along 1t. Fluorite fills fractures, In part, and also replaces the enclosing rocks, which are principally Iimestone and dolomite of the Morelos formation. 
Samples of fluoritized rock collected by the writer from different mines prove that conglomerate of the Balsas group and tuff of the overlying Tilzapotia series were also replaced to a small degree. Mineralization was therefore more recent than accumulation of the Tilzapotla series, which is thought to be of latest Oligocene to earliest Miocene age, and it may thus be of Miocene or even PIlocene age. Post-mineral dissolution of the limestone permitted the overlying rocks to drop into small sinks formed along the mineralized zone.

Small deposits of silver, zinc, copper, and gold occur about $2 \mathrm{~km}$. southwest of $\mathrm{Km}$. 135.6 of the AmacuzacIfuala highway. They are in Cretaceous limestone of the Morelos formation near a contact with Ilmestone conglomerate of the Balsas group, in a small erosion remnant of the latter unit. The area was not mapped in detall because of the lack of photographic coverage, but it is described by Pérez-Martínez (1953) who examined the ore deposits. Other small sold, lead, and silver deposits occur along the contact between Morelos IImestone and the Buenavista stock southwest of Buenavista de Cuéllar, opposite $\mathrm{Km}$. 145 of the Amacuzac-Iguala toll road. A small contact iron deposit and beds of marble are present 2 to $3 \mathrm{~km}$. southwest of the latter deposits, along the same contact.

Important antimony and mercury deposits are present around the borders of the area mapped. The northemmost 
deposit of mercury is in Morelos limestone and possibly in part in Xochicalco limestone at a place called Santa Rosa, located only $10 \mathrm{~km}$. west of Cerro Xochlcalco (quad. E-5). Other mercury deposits occur in the vicintty of Huahuaxtia, a few kilometers west-southwest of the edge of the map south of Taxco (quad. I-1). Ore in the latter locality is in faults that cut the Morelos, Cuautla, and Mexcala formations (Gallagher and Pérez-S1I1ceo, 1948). Just south of the town of Huitzuco (fig. I), only 12 to $15 \mathrm{~km}$. east of the southeasternmost edge of the geologic map in plate 1 , are deposits of mercury and antimony in which the most important primary ore mineral is Ilvingstonite, a complex sulfide of the two metals. The ore is mainly in limestone, dolomite, and anhydrite of the Morelos formation. In earlier descriptlons of these deposits (MCAllister and Hernández-Ortiz, 1945), both dolomite and anhydrite were attributed to hydrothermal replacement of limestone, no regional stratigraphic studies having been made beforehand to serve as a basis for geologic interpretation of the deposits, but they are clearly the same members that are present in many other parts of the region and described in other chapters of this report.

Important non-metall1c mineral deposits are also present in the area mapped. Apart from the fluorite north of Taxco, Iimestone serves as raw material for the production of quick lime in large kilns along the highway south 
of Xiutepec (quad. D-6) and west of Xochitepec (quad. E-6), as well as in small local kilns scattered here and there over the region. The Cuautla formation is by far the best rock for this purpose, as it lacks the dolomite so common in the Horelos formation, but even Iimestone conglomerate of the Balsas group and Cuemavaca, formation, as well as Recent caliche are used locally where the limestone formations are absent. A Portland cement plant along the railroad Just north of Xiutepec (quad. D-6) obtains 1ts Iimestone and shale raw material from quarries in the Cuautla and Mexcala formations in Cerro Xiutepec a few kilometers south of town. Iron ore for special cement and gypsum are also mined locally. Gypsum is mined from the Balsas group on a small scale just north of Oacalco (quad. C-8) and between Cocoyoc and Oaxtepec (quad. D-9), and also from the Cuernavaca formation in the valley leading southeast from Tlaltizapán (quad. G-7). Gypsum and anhydrite are mined on a somewhat larger scale from quarries in the anhydrite member of the Morelos formation exposed on the steep hillside just southeast of Tilzapotla (quad. I-5).

Bullaing stone is quarried in the Taxco region from the Tilzapotla series, particularly the thin-bedded greenIsh and redaish tuffaceous sandstone between this series and the underlying Balsas group. The black dacitic pitchstone (welded tuff or 1gnimbrite) just above the sandstone and the 
overlying dense rhyolite welded tuff are also quarried. Much ornamental rock comes from quarries in these beds along the Amacuzac-Taxco highway between $\mathrm{Km} .146$ and $\mathrm{Km} .156$. Slabby or flaggy Ilmestone of the Xochicalco formetion is quarried in cerro Acuitlapán (quad. G-2). Many of the other rock units, including basalt of the Chichinautzin series, are quarried locally for building stone and construction purposes. Redalsh oxidized scoria (tezontle) from small cinder cones is mined on a moderately large scale at TezoJuca (quad. E-6), TepetIixpa (quad. B-II), Amecameca (quad. A-il), and the northeast edge of Cuernavaca (quad. C-6), for road and rallroad ballast and surfacing and for other construction. Numerous large quarries have been opened in the Cuernavaca formation in and around the city of Cuernavaca, to extract sand and gravel for concrete and local bullding. Some of these quarries are locally called "sand mines". Utilization of the non-metallic mineral resources of the region is increasing rapidly in volume and will continue to expand as the region developes and grows. 
Areliano, A. R. V., 1948, La composictón de las rocas volcánicas en la parte sur de la cuenca de Méjico: Soc. geol. mexicana, Bol., t. 13, p. 81-82.

1948 (1951), The Becerra Iormation (latest Ple1stocene) of central Mexicos 18th Internat. geol. Cons. (London), Mem., pt. 11, p. 55-62.

, 1953, Estratigrafla de la cuenca de Méxicos Cong. clent. mexicano, Mem., v. 3, p. 172-186.

Alvarez, José, 1949, Correlación entre la distribución ictiofaunística y los cambios geomorfológicos: Soc. geol. mexicana, Bol., t. 14, p. 39-45.

Bárcena, Mariano, 1874, Viaje a la caverna de Cacahuamilpa; datos para la geologla y la flora de los Estados de Morelos y Guerrero: La Naturaleza, I ser., v. 3, p. 75-92.

- 1875, Datos para el estudio de las rocas mesozo1cas dé México y sus fósiles caracterfsticos: Soc. Geog. y Estadistica, Bol., t. 2, no. 7, p. 369-405.

Barrera, Tomás, 1946, Gúla geológlca de Oaxaca: Inst. de Geologia (Mexico), Mon., loI p.

Bauman, C. F., Jr., 1958, Dos radiolftidos nuevos de la reglón de Cuermavaca, Morelos: Inst. de Geologla (Mexico), Paleont. mexicana, no. 3.

Beales, F. W., 1958, Anclent sediments of Bahaman type: Am. Assoc. Petroleum Geologists, Bull., v. 42, no. 8, p. 1845-1880.

Bodenlos, A. J., 1956, Notas sobre la geologla de la Sierra Madre en la sección Zimapén-Tamazunchale: XXo Cong. geol. internal. (Mexico), Ifbreto-gula Excunsiones A-14 y C-6, p. 293-309.

Bohnenberger-Thomas, Otto, 1955, Bosquejo geológ1co a 10 lar80 de la carretera Iguala-Chilpancingo, Estado de Guerrero: Univ. nal. autónoma de México, Tesis prof., 61 p., unpublished.

Bonet, Federico, 1952, La facies urgoniana del Cretáclco Medío de la región de Tampico: Asoc. mexicana Geólogos petrol., Bol., v. 4, p. 153-262. 
Bonet, Federico, 1956, Zonificación microfaunistica de las calizas cretáclcas del este de México: XXo Cong. geol. intermal. (Mexico), Mon., 102 p. .

, 1956, (Excursión espeleológica; visita a las Grutas de Cacahuamilpa y a otras grutas y cavernas de los Estados de México, Morelos y Guerrero): XXo Cong. geol. Internal. (Mexico), Ifbreto-guía Excursión C-17, unpubilshed.

Böse, Em11, 1923, Algunas faunas cretéc1cas de Zacatecas, Durango y Guerrero: Inst. geol. México, Bol. 42,219 p.

Böse, Emil, and Cavins, 0. A., 1927, The Cretaceous and Tertiary of southern Texas and northern Mexico: Univ. Texas, Bull. 2748, p. 7-142.

Bryan, Klrk, 1948, Los suelos complejos y fós1les de le, altiplanicie de México, en relación a los camblos climáticos: Soc. geol. mexicana, Bol., t. 13, p. 1-20.

Burckhardt, Carlos, 1906, Sobre el descubrimiento del Trias marino en Zacatecas: Soc. geol. mexicana, Bol., t. 2, p. $43-45$.

1919, Faunas jurás1cas de Symón (Zacatecas) J faunas cretáclcas de Zumpango del Rlo (Guerrero): Inst. geol. Méx1co, Bol. 33, t. 1, 135 p.; 1921, t. 2, 32 pl.

, 1930 Etude synthét1que sur le Mésozolque méx1cain: Soc. paléont. Suls8e, Mém. 49-50, $280 \mathrm{p}$.

Calderón-Garcla, Ale jandro, 1956, Bosque jo geológ1co de la región de San Juan Raya, Puebla: XXQ Cons. geol. Interna1. (Mexico), I1breto-gula Excursión A-11, p. 9-27.

Conkin, J. E., and Conkin, B. M., 1958, Revision of the genus Nummoloculina and emendation of Nummoloculina helm1 Bonet: Micropaleontology, v. 5, no. 2, p. 149-158.

De Buen, Fernando, 1946, Ictiogeografla continental mexicana: Soc. mexicana H1st. natural, Rev1sta, t: 7, no. 1-4, p. 87-138.

De la O-Carreño, Alfonso, 1951, Las provincias geohldrológlcas de Méxlco; Prlmera Parte: Inst. de Geología (Mexico), Bol. 56, $137 \mathrm{p}$.

Edwards, J. D., 1955, Studies of some early Tertiary red conglomerates of central Mexico: U. S. Geol. Survey, Prof. Paper 264-H, p. 153-183. 
Erben, H. K., 1956, Estratigrafĺa a 10 largo de la carretera entre México, D. F. I Tlaxiaco, Oaxaca, con particular referencla a clertas áreas de 108 Estados de Puebla, Guerrero y Oaxaca: XX- Cong. geol. Internal. (Mexico), Iibreto-guía Excursión A-12, p. 11-36.

Faust, G. T., Schmitter, Eduardo, and Fries, Carl Jr., 1950, (Note on the occurrence of portiandite in Mexico): Am. Mineralogist, v. 35, p. 614.

Femández-G., R., 1956, Nota sobre Ia mina Ia Azul: XX ..? Cons. geol. Internal. (Mexico), Libreto-gúa Excursiones A-4 y C-2, p. 91-93.

Flores, Teodoro, 1920, Estudio geológ1co-minero de los distritos de EI Oro $\mathrm{J}$ TIalpujahua: Inst. geol. México, Bol. 43.

, 1946, Geología minera de la región noreste del Estado de Michoacán: Inst. de Geologla (Mexico), Bol. 52, $106 \mathrm{p}$.

Foshag, W. R., González-Reyna, Jenaro, and Pérez-S1l1ceo, Rafael, 1946, Los depósitos de fluorita del distrito mínero de l'axco, Estado de Guerrero: Bol. Minas y Petróleo (Mex1cd, no. 7, p. 3-8, and no. 8, p. 3-7.

Fowler, G. M., Hernon, R. M., and Stone, E. A., 1948, The Taxco mining district, Guerrero, Mexico: 18th Internat. geol. Cong. (Iondon), Hem., pt. 7, p. 1-12.

Fries, Carl, Jr., Hibbard, C. W., and Dunkle, D. H., 1955, Eariy Cenozo1c vertebrates in the red conglomerates at Guana juato, Mexico: Smithsonian Institution, Misc. Coll., 123, no. 7 , p. $1-25$.

Fries, Carl, Jr., 1956a, Bosque fo geológfco de la reglón entre México, D. F. y Taxco, Gro.: XXo Cong. geol. Internal. (Nex1co), ilbreto-gula Excursiones A-4 y C-2, p. $11-36$.

1956b (1957), Bosquejo geológ1 co de la región entre Mexico, D. F. J Acapulco, Gro.: XXO Conf. geol. Internal. (Mexico), Libreto-gula Excursiones A-9 y C-12, in Asoc. mexicana Geólogos petrol.; Bol., v. 9 , no. $5-6$, p. $287-333$.

, 1956c (In press), Bosquejo geolósico de las partes central y occidental del Estado de Morelos $\mathrm{J}$ áreas cont1guas de Ios Estados de Guerrero J México: XXO Cong. geol. internal. (Nexico), I1breto-gula Excursión C-9. 
Galindo y V1lia, Jesús y Dolores, 1946, Geografla sumaria de la República Mexicana, México, D. F.

Gallagher, David, and Pérez-Siliceo, Rafael, 1948, Geology of the Huahuaxtla mercury district, State of Guerrero, Mexico: U. S. Geol. Survey, Bull. 960-E, p. 149-175.

Gándara, Guiliermo, and Muñoz-Lumbier, Manuel, 1935, Perfil botáni co-geológlco de la carretera México-Acapulco; Sría. Economlá Nacional, Oficina Geog. econ., Mon., 57 p.

Garflas, V. R., and Chapin, T. C., 1949, Geologla de Méx1co, 202 p., Editorial Jus, México, D. F.

Geyne, A. R., 1956, Las rocas volcánicas y los yacimientos argentiferos del distrito minero de Pachuca-Real del Monte, Estado de HIdalgo: XXO Cong. geol. Internal. (Mexico), Ifbreto-gula Excursiones A-3 y. C-1, p. 47-57.

Guzmån, E. J., 1950, Geologfa del noreste de Guerrero: Asoc. mexicana Geólogos petrol., Bol., v. 2, no. 2, p. 95-156.

Hall, C. E., 1903, Notes on a geological section from IguaIa to Totolapa, State of Guerrero, Mexico: Soc. clent. Antonio Alzate, Mem., v. 13, p. 327-335.

Heim, Arnold, 1940, The front ranges of slerra Madre Oriental, Mexico, from Cludad V1ctorla to Tamazunchale: Eclogae geol. helvet1ae, v. 33, p. 313-352.

Illing, L. V., 1954, Bahamen calcareous sands: Am. Assoc. Petroloum Geologlsts, Bull., v. 38, p. 1-95.

Iozano-García, Raúl, 1953, Fenómenos de erosión en la región de Tepoztlón, Estado de Morelos y en el valle del Mezqultal, Estado de Hidalgo: Cong. clent. mexicano, Mem., pt. 3, p. 206-217.

Maldonado-Koerdel1, Manuel, 1948, Nuevos datos geológicos y paleontolósicos sobre el Trísico de Zacatecas: Escuela nal. Clencias biol. (Mexico), Anales, v. 5, no. 3-4, p. 291-306.

McAllister, J. F., and Hernández-Ort1z, Dav1d, 1945, Quicksilver-antimony deposits of Hultzuco, Guerrero, Mexico: U. S. Geol. Survey, Bull. 946-B, p. 49-71.

Menard, H. W., 1955, Deformation of the northeastern Pacific beistn and the west coast of North America: Geol. Soc. Amer1ca; Bull., V. 66 , p. 1149-1196. 
Mooser, Federico, 1956 (In press), Bosquejo geológico del extremo sur de la cuenca de México: XX⿳亠口冋. Cong. geol. 1nternal. (Mexico), Libreto-gula Excursión C-9.

Muir, J. M., 1936, Geology of the Tampico region, Mexico, 280 p., Am. Assoc. Petroleum Geologists, Thlsa, Oklahoma.

Müllerrled, F. K. G., 1943, Paleontologla y estratigrafĺa del Mesozolco en el valle de Tixtla, Estado de Guerrero: Escuela nal. Cienclas blol. (Mexico), Anales, v. 3, no. $1-2$, p. 235-264.

1944, Geologla, estratigrafla y paleontología de la región de Cacahuamilpa (México): Escuela nal. Cienclas blol., Anales, v. 3 , no. $3-4$, p. 463-482.

1950, Radiolftido supracretác1co de Tlaquiltenango, Estado de Morelos: Soc. mexicana H1st. natural, Revista, t. 11 , no. $1-4$, p. $223-228$.

Newell, N. D., and Rigby, J. K., 1957, Geolog1cal studies on the Great Bahama Bank; symposium of reglonal aspects of carbonate sedimentation: Soc. Econ. Paleont. and Min., Spec. Paper 5.

Ordóñez, Ezequiel, 1895, Las rocas exuptivas del suroeste de la cuenca de México: Inst. geol. México, Bol. $2,56 \mathrm{p}$. , 1900, Las rhyolitas de México: Inst. geol. Méx1co, Bol. 14, 75 p.

- 1901, Las rhyolitas de México; 2 parte, Descripción sistemática de las rhyolitas: Inst. geol. México, Bol. $15,76 \mathrm{p}$.

- 1937a, El salto de San Antón, Cuemavaca, Morelos: Soc.geol. mexicana, Bol., t. 1-2, p. 7-23.

, 1937b, Tepoztián, Estado de Morelos: Soc. geol. mexicana, Bol., t. 3-4, p. 3-24.

21946, Principales provincias geográficas y geológlcas de la República Mexicana, in Gufa del explorador minero, Cap. VI: Com. direct. Invest. Recursos min. (He$x(c 0)$, p. 103-142.

Osborne, T. C., 1956, Geologla y depósitos minerales del distrito minero de Taxco: XX' Cong. geol. Internal. (Mexico), Libreto-gufa Excursiones A-4 y C-2, p. 75-89. 
Osorio-Tafall, B. F., 1946, Anotaciones sobre algunos aspectos de la hidrologla mexicana: Soc. mexicana Hist. natural, Revista, t. 7, no. 1-4, p. 139-165.

Palmer, R. H., 1928, The mudistids of southern Mexico: California Acad. Sc1., Occasional Paper 14, 137 p.

Pantoja-Alor, Jerjes, 1957, Bosquejo geológico de la región de Huetamo, Michoacán: Inst. politécnico nal. (Mexico), Tesis prof., 64 p., unpublished.

Pérez-Hartinez, J. J., 1953, Geologla y posibilidades económicas de la mina Manuel; Coxcatión, Municlplo de Buenavista de Cuéllar, Gro.: Inst. nal. Invest. Recursos min., Bol. 34-E, p. 43-56.

Prister, Augusto, 1927, Notas preliminares sobre vest1g10s glaclales en el Estado de Hidalgo y en el valle de México: Soc. cient. Antonio Alzate, Mem., t. 48, p. 1-13.

Robles-Ramos, Ramiro, 1942, El Cerro de la Palma: Minerla, v. 1 , no. 2 .

Salas, G. P., 1949, Bosque jo geológico de la cuenca sedimentaria de Oexaca: Asoc. mexicana Geólogos petrol., Bol., v. 1, no. 2, p. 79-156.

Santilián, Manuel, 1929, Geologla minera de las regiones norte, noroeste y central del Estado de Guerrero: Inst. geol. México, Bol. 48, p. 47-102.

Schmitter, Eduardo, 1953, Investigación petrológica en las lavas del Pedregal de San Angel: Cong. cient. mexicano, Nem., t. 3 , p. 218-237.

Segerstrom, Kenneth, 1956, Estrat1grafla y tectónica del Cenozo1co entre México, D. F. Y Zlmapán, Hidalso: XXQ Cong. geol. Internal. (Mexico), Ilbreto-gúa Excursiones A-3 y C-1, p. 11-22; Iibreto-guía Excursiones A-I4 y C-6, p. $311-323$.

- In press, Geology of southwestern Hidalgo and northem Mexico State: U. S. Geol. Survey, Bull.

S1mons, F. S., and Mapes-Vázquez, Eduardo, 1956, Geology and ore deposits of the zlmapán mining district, state of HIdalgo, Mexico: U. S. Geol. Survey, Prof. Paper 284, $128 \mathrm{p}$. 
V1rlet-d'Aoust, Theodore, 1866, Coup d'oell general sur Ia topographie et la geologie du Mexique et de I'Amerique Central: Soc. geol. France, $2 d$ ser., v. 23.

White, D. E., 1947, Diggenetic orlgin of chert lenses in Iimestone at Soyatal, State of Querétaro, Mexico: Am. Jour. Sc1., v. 345 , p. 49-55.

Wilcox, R. E., 1954, Petrology of Paricutin Volcano, Mexico: U. S. Geol. Survey, Bull. 965-C, p. 281-353.

W1lliams, Howel, 1950, Volcanoes of the Parlcutin region, Mexico: U. S. Geol. Survey, Bull. 965-B, p. 165-279.

Wilson, B. W., Hernández, J. P., and Meave-Torrescano, Edgardo, 1955, Un banco cal1zo del Cretáclco en la parte orlental del Estado de Querétaro, Méx1co: Soc. geol. mexicana, Bol., v. 18, no. 1, p. 1-10.

Zepeda-Rincón, Tomás, 1941, La Repúbllca Mexicana, geografla y atlas, México, D. F. 


\section{APPENDIX}

Provenance, petrographic description, and faunal content of rock samples cited in the text

The rock samples and specimens in the following list are arranged consecutively according to the year in which they were collected and the number in each year. The general order of description of each sample consists of I) sample or specimen number, 2) provenance, 3) formation or rock unit represented and age (if known), 4) petrographic details (1f studied), 5) faunal content (if present and determined), and 7) collector (other than the writer). Localities mentioned may be found by referring to the geologic map in plate 1 or the index map in plate $3-A$; the sheet number of plate $I$ and the quadrangle in which the locality is present are in parentheses as follows: (sheet 2, quad. $\underline{H}-3$ ). The specialists who studied or examined the rocks, minerals, and fossils not Identified by the writer, or who helped to collect the sample, are mentioned in each sample description; in order not to repeat the name of the organizational unit with which each one is assoclated, however, their names are Iisted alphabetically below, followed by the corresponding organizational association at the time the work was done.

Esther R. Applin, geologist, U. S. Geological Survey. otto Bohnenberger-Thomas, candidate for degree in geology, Universidad Nacional Autónoma de Inéxico. 
Federico Bonet, paleontologist and biologist, Petróleos Hexicanos.

C. Wythe Cooke, paleontologist, U. S. National Iuseum.

Gloria Alencáster de Cserna, paleontologist, Instituto de Geologfa, Universidad Nacional Autónoma de México.

Zoltan de Cserna, geologist, Instituto de Geologla, Universidad Nacional Autonoma de México.

Raymond C. Douglass, paleontologist, U. S. Geological Survey.

Stewart H. Folk, geologist, Degolyer and MacNaughton, consultants to Petróleos liexicanos.

Ralph W. Imlay, stratigrapher and paleontologist, U. S. Geological Survey.

Howard W. Jaffe, geochemist, U. S. Geological Survey, and colleagues.

Alfred R. Loeblich, Jr., paleontologist, U. S. National Museum.

Jerjes Pantoja-Alor, candidate for degree in geology, Instituto Politecnico Nacional (Mexico).

H. Wesley Peirce, mineralogist, Arizona Bureau of Mines.

Richard Rezak, paleontologist and paleobotanist, U. S. Geological Survey.

S. R. Romo-Jiménez, paleontologist, Petróleos lfexicanos.

Clarence S. Ross, petrolog1st and mineralogist, U. S. Geological Survey.

Eduardo Schmitter, petrologist and mineralogist, Instituto de Geología, Universidad Nacional Autónoma de México.

Norman I. Sohl; paleontologist, U. S. Geological Survey.

Iloyd W. Stephenson, paleontologist, U. S. Geological Survey.

Ruth Todd, paleontologist, U. S. Geological Survey,

John W. Wells, professor and paleontologist, Cornell University. 
Bernard W. Wilson, geologist, U. S. Geological Survey.

\section{0}

F-1-50. West base of Cerro de las Tetillas, $1000 \mathrm{~m}$. east of $\mathrm{Km}$. 17 of the Cuernavaca-Cuautla highway (sheet I, quad. D-7). Volcano referred to the Chichinautzin basalt serIes; of probable middle Pleistocene age. Porphyritic, holocrystaline, olivine basalt with pllotaxitic matrix (pl. $22+B)$. Olivine phenocrysts are up to $2 \mathrm{~mm}$. across, have rims of serpentine. Feldspar microlites are less than 0.4 m. long and are about $\mathrm{An}_{65}$. Iatrix contains abundant ausite grains, which, with olivine, make up nearly half the rock.

F-3-50. Near El Progreso, at Km. 13.5 of the CuernavacaCuautla highway (sheet 1, quad. D-7). Lava from Cerro de la Corona volcanic neck, part of the Chichinautzin basalt series; of probable middle Pleistocene age. Glomeroporphyritic, hypocrystalline, olivine basalt with hyalopilitic matrix (pl. 22-F). Olivine crystals are up to $1.2 \mathrm{~mm}$. across, in clusters, make up some 5 per cent of the rock. Plagioclase phenocrysts are calcic labradorite and form about 15 per cent of the total; plagioclase microlites are bytownite to labradorite. Matrix contains abundant augite grains and about 3 per cent glass. F-4-50. Near El Progreso, at Km. 12.5 of the CuernavacaCuautla highway (sheet 1 , quad. D-7). Iava from uneroded 
flow, part of the Chichinautzin basalt series; of probable Recent age. Glomeroporphyritic, holocrystaline, olivine basalt with pilotaxitic to ophitic matrix (p1. 22-E). OIivine crystals are up to $2 \mathrm{~mm}$. Iong and form some onefourth of the rock. Feldspar microlites are less than 1 mm. Ions, about $\mathrm{An}_{60}$; matrix contains augite. Rock is fresh and unaltered.

F-5-50. Near Km. 19 of the Cuernavaca-Cuautla highway (sheet 1, quad. D-7). Upper part of the Morelos formation; of probable early Cenomanian age. Dense, dark-gray to reddish foraminiferal calcilutite (pl. 12-C). Rock contains partly slicified maistid fragments and some individuals of Dicyclina schlumbergeri Munier-Chalmas, together with other millolids.

F-7-50. Five thousand meters due south of $\mathrm{Km}$. 15 of the Cuernavaca-Cuautla highway (sheet 1, quad. D-7). Basic dike cutting the Morelos formation; of probable early Tertiary age. Porphyritic olivine-hypersthene basalt with pilotaxitic matrix (pl. 20-E). Phenocrysts are up to $1.2 \mathrm{~mm}$. across; olivine is almost completely altered to nontronite(?). Pyroxene phenocrysts are mainly hypersthene but also include a little clinopyroxene. Feldspar microlites are up to $0.1 \mathrm{~mm}$. Iong and are about $\mathrm{An}_{60^{\circ}}$ Matrix augite(?) is altered to nontronite( $(3)$.

F-10-50. Km. 22.8 of the Cuernavaca-Cuautla highway (sheet 1, quad. D-7). Lava from a vent on the east side of Cerro 
de las Tetillas, part of the Chichinautzin basalt series; of probable midale Pleistocene age. Porphyritic, holocrystalline, olivine-pyroxene basalt with granulitic matrix pl. 22-C). Olivine crystals are up to $1.3 \mathrm{~mm}$. Iong, are rimmed with brown 1ddingsite(3). Pyroxene phenocrysts are more abundant, seem to consist of plgeonite(?). Feldspar microlites are about $A n_{70}$; matrix pyroxene is augite and forms some 30 per cent of the rock.

F-12-50. About $300 \mathrm{~m}$. southwest of Cerro de la Corona volcanic neck, south of $\mathrm{Km} .15 .5$ of the Cuernavaca-Cuautla highway (sheet I, quad. D-7). Wladle part of the Cuautla formation; of late Turonian age. Medium-gray dense calcarenite with silicified individuals of a small species of Hippurites which may be new and is here referred to as species a. Examined by G. A. de Cserna.

F-13-50. About $300 \mathrm{~m}$. southwest of Cerro de la Corona volcanic neck, south of $\mathrm{Km}$. 15.5 of the Cuernavaca-Cuautla highway (sheet I, quad. D-7). Middle part of the Cuautla formation; of late Turonian age. Medium-gray dense limestone with individuals of Duranle cornu-pastoris and silicifled shells of Toucasia sp. and Radiolites sp. Rock contains chert nodules. Examined by G. A. de Cserna. F-18-50. Ridge top $3900 \mathrm{~m}$. due east of the center of Emiliano Zapata (sheet 1 , quad. D-6 and D-7). Upper part of the Morelos formation; of late Albian or early Cenomanian age. Ifght-yellowish-gray dense limestone with much nodu- 
lar chert; contains miliolids and many small silicified individuals of Toucasia patasiata(?) about $25 \mathrm{~mm}$. in diameter.

F-20a-50. Cut along the highway $300 \mathrm{~m}$. beyond the north edge of Emiliano Zapata (sheet 1, quad. D-6). Lower part of the Mexcala formation; of early Coniacian age. Slightly redish to medium-gray argillaceous calcilutite interbed containing srains of limestone, rare quartz, and possibly dolomite, besides about 15 per cent of microfossils, which inc̈lude Globotmuncene sp., Gümbelina sp., Globiger1na (?), and Calcisphaerula (?).

F-21-50. Cut along the highway $350 \mathrm{~m}$. beyond the north edge of Emiliano Zapata (sheet 1, quad. D-7). Lower part of the Mexcala formation; of earlyConiacian age. Iight-brown, highly calcareous subgraywacke interbed containing about 15 per cent quartz, the rest consisting of clastic grains of limestone, dolomite, rare feldspar, rare mica, and secondary chlorite (pl. 18-c). The dolomite was suggested by staining the rock, and the presence of appreciable magnesium was proved by an arc spectrum test made by H. W. Peirce. F-22-50. Near the limestone-shale contact on the hillside 3200 m. S. $67^{\circ}$ E. of the center of Emiliano Zapata (sheet 1, quad. D-6 and E-7). Upper part of the Cuautla formation; of late Turonian ase. Very dense, slightly reddish Iimestone with possibly a new species of Hippurites, here called species $\underline{b}$; the larger valve has a top diameter of 
about $25 \mathrm{~mm}$. and a length of some $50 \mathrm{~mm}$. The specimen comes from the highest bed with Hippurites in this section. Examined by G. A. de Cserna.

F-23-50. Ridge top 3600 m. S. $67^{\circ} \mathrm{E}$. of the center of Em1llano Zapata (sheet 1 , quad. D-6 and E-7). Lower part of the Cuautla formation; of Turonian age. Iight-gray to slightly reddish, very dense limestone with numerous biostromes containins Toucasia sp., Hippurites sp., Nërinea sp., Radiolites perforata Palmer, and other species of Radiolites. From within $20 \mathrm{~m}$. of the base of the Cuautla formation. Examined by G. A. de Cserna.

F-25-50. Crest of the range $5200 \mathrm{~m}$. S. $69^{\circ} \mathrm{E}$. of the center of Emiliano Zapata (sheet I, quad. D-6 and E-7). Well down in the Morelos formation; of probable late Albian age. Very light brownish gray, saccharoldal, highly dolomitized Iimestone. Dolomite crystals are about $0.2 \mathrm{~mm}$. In diameter, but some calcite crystals in the matrix are up to 0.6 mm. across. Completely recrystallized, with loss of original texture and no trace of fossils.

F-32-50. $\mathrm{Km}$. 31 of the Alpuyeca-Yautepec hishway, just north of Tlaltizapán (sheet 2, quad. F-7). Top of the Cuernavaca formation, of probable early Pleistocene age. Freshwater Iimestone or travertine composed of unidentifiable curved fragments of turbid-yellow, cryptocrystalline calc1te, up to $6 \mathrm{~mm}$. long; clear calcite matrix formed of crystals up to $0.25 \mathrm{~mm}$. across (pl. 18-B). Lime probably 
precipitated on organic matter which was subsequently destroyed by oxidation and bacterial action; matrix calcite crystallized later.

F-33-50. Quarry on the north side of the highway at $\mathrm{Km}$. 17.2 of the Cuernavaca-Cuautla highway (sheet 1 , quad. D-7). Lower part of the Hexcala formation; of early Conlacian age. Gray subgraywacke interbedded with shale and siltstone, with impression of an ammonoid determined by $R$. W. Imlay as Peroniceras sp.

F-34-50. About $500 \mathrm{~m}$. north of Cerro de la Corona volcanic neck, south of $\mathrm{Km}$. 15.5 of the Cuernavaca-Cuautla highway (sheet 1 , quad. D-7). Lower part of the Cuautla formation; of Turonian age. Medium-gray dense limestone with abundant individuals of a small Radiolites and Toucasia sp., all nearly completely sllicifled; abundant chert nodules. Dissolution in hydrochloric acid released an individual of Toucasia with articulated valves. The second, right valve is a small, nearly flat, operculum-Iive cover, distinguishins this species from the well known. T. texana and I. patagiata of middle and probably late Albian age and possibly even early Cenomanian age. Examined by R. W. Imlay. F-38-50. H1IItop $400 \mathrm{~m}$. due west of $\mathrm{Km}$. 19 of the Cuernavaca-Cuautla highway (sheet 1, quad. D-7). Upper part of the Morelos formation; of probable early Cenomanian age. Mottled, light- to dark-gray, irregularly dolomitized calcarenite ( $\mathrm{pl}$. 1l-c). Rock contains unidentifiable biogenic 
grains and fragments.

F-44-50. R1dge $600 \mathrm{~m}$. N. $10^{\circ}$ W. of Cerro de la Corona volcanlc neck, south of $\mathrm{Km}$. 15.5 of the Cuernavaca-Cuautla highway (sheet 1, quad. D-7). Upper part of the Cuautla formation; of late Turonian age. Medium-gray dense limestone with repeated biostromes of large individuals and colonies of Hippurites resectus var. mexicanus Bárcena, associated with Toucasia sp. and two or three species of Radiolites (see pl. 17-B). Examined by G. A. de Cserna. F-45-50. Hillside $700 \mathrm{~m}$. N. $10^{\circ}$ E. of Cerro de la Corona volcanic neck, south of $\mathrm{Km}$. 16 of the Cuernavaca-Cuautla highway (sheet 1 , quad. D-7). Middle part of the Cuautla formation; of Turonian age. Medium-gray dense limestone blostrome contalning large silicified individuals of a probable new species of Radiolites, here named a, about 20 $\mathrm{mm}$. across the top of the larger valve and $40-45 \mathrm{~mm}$. Iong. Examined by G. A. de Cserna.

F-53-50. West bank of the Chinameca River about $600 \mathrm{~m}$. upstream from the briage on the Tlaquiltenango-Huautla road (sheet 2, quad. $\underline{-}-7$ ). Lower part of the Mexcala formation; of early Coniacian age. Gray to purplish siltstone and shale with interbeds of subgraywacke, containing an ammonold impression referred by $R$. W. Imlay to Peroniceras sp. F-57-50. East bank of the Chinameca River at the south edge of the town of Ia Era (sheet 2, quad. H-7). Lower part of the Mexcala formation; of early Coniacian age. Slabby, 
gray siltstone with individuals of Peroniceras cf. $\underline{P}$. subtricarinatum Sturm. Identified by R. W. Imlay.

F-59-50. East bank of the Chinameca River about $800 \mathrm{~m}$. (airline) downstream from La Era (sheet 2, quad. H-7). Lower part of the Mexcala formation; of early Coniacian age. Greenish calcareous subgraywacke and siltstone interbedded with dark-gray and purplish shale, containing individuals of Barrolsiceras of. B. alstadenense Solger, Peroniceras cf. P. subtricarinatum Drescher, Peroniceras cf. P. subtricarinatum Sturm, and "Crioceras" sp. Ident1fied by R. W. Imlay.

F-60-50. East bank of the Chinameca River about $1200 \mathrm{~m}$. (airline) downstream from La Era (sheet 2, quad. H-7). Lower part of the Mexcala formation; of early Coniacian age. Greenish calcareous subgraywacke and siltstone, similar to F-29-50, containing individuals of Barroisiceras of. B. haberfellneri von Hauer, Peronlceras of. P. ozörnig1 Redtenbacher, and otoscaphites cf. O. geinitzi (Jahn). Identified by R. W. Imlay.

F-6I-50. West bank of the Chinameca River $2000 \mathrm{~m}$. (alrine) downstream from La Era (sheet 2, quad. H-7). Basal part of the Mexcala formation; of early Coniacian age. Brownish to grayish, slabby, calcareous siltstone and subgraywacke from the lowermost $10 \mathrm{~m}$. of the Mexcala formation. Beds contain impresaions of Barrolsiceras sp., Otoscaphites cf. O. auritus (Schlüter), and Didymotis cf. D. trinidadensis 
Sommermeler. Identified by R. W. Imlay.

F-63-50. Southward meander of the Chinameca River $1000 \mathrm{~m}$. west of Elotes (sheet 2, quad. $\mathrm{H}-7$ ). Iower part of the Cuautla formation; of Turonian age. Medium-gray calcarenite composed largely of biogenic fragments, with ungilicified shells of Toucasia sp. (pl. 14-D).

F-67-50. Southernmost loop of the Chinameca River $400 \mathrm{~m}$. west of Elotes (sheet 2, quad. $\underline{H}-7$ ). Basal thin Ilmestone beds of the Mexcala formation; of early Coniacian age. Medium-gray, thin limestone beds at the base of the MexcaIa formation, within $10 \mathrm{~m}$. of the contact with the underlying Cuautla formation. Beds contain rare individuals of Barroisiceras(?) sp. Examined by R. W. Imlay.

F-68-50. West bank of the Chinameca River $600 \mathrm{~m}$. upstream from Nexpa (sheet 2, quad. H-7). Lower part of the Mexcala formation; of early Coniacian age. Slabby, gray siltstone above the basal thin limestone beds of the Mexcala formation. Beds contain Peroniceras sp. and Didymotis cf. D. trinidadensis Sommermeier. Identified by R. W. Imlay. F-83-50. Near the base of the west flank of the Iimestone ridge $5400 \mathrm{~m}$. due west of the center of Cuautla (sheet 1 , quad. E-9 and E-8). Top part of the Cuautla formation; of late Turonian age. Ilght creamy gray, dense limestone with silicified corals belonging to the genus Columastraea(?) (pl. $15-B$ ), from about $20 \mathrm{~m}$. below the top of the formation. Beds contain also silicified individuals of Toucasia sp., 
Radiolites sp., Actaeonella sp., Hippurites sp. a, and Nerinea sp., as well as chert nodules. Columastraea was Identified by J. W. Wells, and Hippurites was examined by G. A. de Cserna. F-87-50. Km. 39 of the Cuernavaca-Cuautla highway (sheet I, quad. D-9). Lava from the Chichinautzin basalt series; of probable late Pleistocene age. Finely porphyritic olivine-augite basalt with ophitic matrix. Phenocrysts are up to $0.5 \mathrm{~mm}$. across. Hatrix is holocrystalline and about half feldspar and half pyroxene. Feldspar microlites are near $A n_{70}$, and matrix pyroxene is augite.

F-90-50. Lower slope of low hill (Cerrito de Zumpango) aIong the old paved Acapulco highway about $300 \mathrm{~m}$. southeast of Zumpango del Rfo, Guerrero, at the latitude of $\mathrm{Km} .256$ of the new México-Acapulco highway, beyond the south edge of the area of plate 1 (see pl. 3-A). Lower part of the Mexcala formation; of early Coniacian age. This locality is not in the area mapped but is included here because it contains several species of invertebrate fossils that are identical to those in Morelos, which were described in considerable detail by Burckhardt (1919, p. 93-130) and Böse (1923, p. 208-210). The writer re-collected from this 10cality, from grayish-brown to greenish siltstone and shale beds along the road and found the following fauna, as identified by R. W. Imlay: Peroniceras sp., Otoscaphites aff. Scaphites geinitz1 Jahn, Otoscaphites aff. Scaphites auri- 
tus (Schlüter), and Didymotis sp.

F-91-50 and F-92-50 (Petróleos Mexicanos samples PI.53071 and PM.53072). East and west sides of the synclinal valley $5600 \mathrm{~m}$. and $6500 \mathrm{~m}$., respectively, due west of the center of Cuautla (sheet 1 , quad. E-9 and $\underline{E}-8$ ). Lower part of the Mexcala formation; of early Conlacian age. Lightbrown-weathering, gray shale interbeds in a shale-siltstone-sandstone sequence probably within $50 \mathrm{~m}$. of the base of the Mexcala formation. The microfossils were washed out and identified by S. R. Romo-Jiménez, as follows: Globotruncana arca, Globotmuncana conica var. pl1cata, Gümbelina elegans, Gümbelina globifera, Globotruncana canaliculata, Gümbelina pupa, Globotruncana canaliculata var. ventricosa, Globigerina cretacea, Globotruncana conica, Planoglobulina acervulinoldes, and Bolivina monilifera. Collected by S. H. Folk and the writer.

\section{2}

F-19-52. Large quarry south of the highway and the San Iuis Potosí-Tampico railroad, about $10 \mathrm{~km}$. east of Ciudad VaIles, easternmost San Iuls Potos1; located about $350 \mathrm{~km}$. north of the area mapped but included here because it is a well known "reference" locality for this particular facies of limestone of Albian to early Cenomanian age known as the El Abra Iimestone (see pl. 3-A). Upper part of the El Abra limestone; of probably early Cenomanian age. Rock is a 
light-gray foraminiferal calcarenite with abundant individuals of Nummoloculina heimi Bonet and some Dicyclina schlumbergerl Munier-Chalmas (pl. 12-A); upper part of the Morelos formation is both lithologically and faunaliy sim1lar to 1 t.

\section{3}

F-1-53. Large quarry along the road on the east side of Cerro Xiutepec, $2000 \mathrm{~m}$. south of the center of Xiutepec village (sheet 1, quad. D-6). Basal part of the Mexcala formation; of early Coniacian age. Gray calcareous siltstone less than $10 \mathrm{~m}$. above the contact with the underlyIng Cuautla formation, interbedded with mudstone and a few thin beds of argillaceous calcilutite. One poorly pre= served pelecypod impression was identified by $R$. W. Imlay as Inoceramus sp.

F-2-53 to F-15-53. Hillside 2000 m. S. $42^{\circ}$ E. of $\mathrm{Km}$. 13 of the Cuernavaca-Cuautla highway (sheet 1, quad. D-7). Basal part of the Mexcala formation; of early Coniacian age. Interbedded medium-gray calcareous siltstone and thin beds of argillaceous calcilutite within $30 \mathrm{~m}$. of the base of the Mexcala formation. Numerous impressions were found of Barroisiceras $\mathrm{sp}$. and Didymotis cf. D. trinidadensis Sommermeier, as identified by R. W. Imlay. Collected by the writer and B. W. Wilson.

F-17-53. Hillslope $400 \mathrm{~m}$. due west of $\mathrm{Km}$. 17 of the Cuerna- 
vaca-Cuautla highway (sheet 1 , quad. D-7). Well up in the Mexcala formation; of Coniacian age. Iight-gray sandstone or graywacke interbed in a sequence of shale, siltstone, and sandstone beds from an unknow distance, but at least a few tens of meters, above the base of the Mexcala formation. Abraded larger valve of an unidentified species of Durania, at least $26 \mathrm{~cm}$. Iong and $21 \mathrm{~cm}$. across at the top of the valve; the shell wall is up to $2 \mathrm{~cm}$. thlck.

F-18-53. Hillslope $450 \mathrm{~m}$. due west of $\mathrm{Km}$. 17 of the Cuernavaca-Cuautla highway (sheet 1 , quad. D-7). Well up in the Mexcala formation; of Coniacian age. Ilght-gray, buffweathering, calcareous sandstone or graywacke interbed in a sequence of shale, siltstone, and sandstone beds from an unknown distance, but at least some tens of meters, above the base of the Mexcala formation. Abraded and poorly preserved ammonoid, $12 \mathrm{~cm}$. across, 1dentified by R. W. Imlay as Peroniceras sp.(?), with colling similar to but more open than that of the genus Texanites, which is common in the Taylor group (Campanian) of Texas. F-22-53. Hillslope $400 \mathrm{~m}$. due west of $\mathrm{Km}$. 17 of the cuernavaca-Cuautla hishway (sheet 1 , quad. D-7). Well up in the Mexcala formation; of Conlacian age. Light-gray, buffweathering, calcareous sandstone or graywacke interbed in a sequence of shale, siltstone, and sandstone beds from an unknown distance, but at least several tens of meters, above the base of the Mexcala formation. From same local- 
ity as F-17-53. Several impressions 1dentified by R. W. Imlay as Pteraptychus(?) Trauth.

F-23-53. Upland surface $800 \mathrm{~m}$. due west of $\mathrm{Km} .17$ of the Cuernavaca-Cuautla highway (sheet 1, quad. D-7). Middle part of the Cuautla formation; of late Turonian age. Large, stubby individuals of a silicified Hippurites, here called new species $\underline{b}$, in a medium-gray, dense calcarenite together with Toucasia sp. and Radiolites sp. Examined by G. A. de Cserna.

F-25-53. Upland $500 \mathrm{~m}$. due west of $\mathrm{Km}$. 18 of the Cuernavaca-Cuautla highway (sheet I, quad. D-7). Upper part of the Inorelos formation, of probable early Cenomanian age. Medium-gray calcarenite replete with foraminlfera, among which Nummoloculina heimi Bonet and Dicyclina schlumbergeri Munier-Chalmas are abundant, together with fragments of Toucasia patagiata(3), Praeradiolites sp., Ostrea sp., and Hyposalenia ( $(3) \mathrm{sp.}$ (pl. 12-D). Ostrea was 1dentified by $G$. A. de Cserna, and Hyposalenia by C. W. Cooke. F-26-53 to F-28-53. Upland $300 \mathrm{~m}$. due east of Cerro de la Corone volcanic neck, west of $\mathrm{Km}$. 18 of the CuernavacaCuautla highway (sheet 1, quad. D-7). Upper part of the Morelos formation; of probable early Cenomanian age. Iight-gray to light-cream, cryptocrystalline calcilutite with individuals of Toucasia patagiata(3), Praeradiolites sp., gastropods, oysters, and abundant foraminifera, among which are Triloculina sp., Quinqueloculina sp., Nummolocu- 
lina heimi, Spiroluculina sp., Nonion(?) sp., and Dicyclina schlumbergeri. These samples are lithologically and faunally nearly ldentical to the upper part of the EI Abra formation (cf. pl. 12-A and specimen F-19-52). Foraminifera were identified by F. Bonet.

\section{$\underline{1954}$}

F-4-54. Upland spur $1150 \mathrm{~m}$. due west of $\mathrm{Km} .19 .5$ of the Cuernavaca-Cuautla highway, or $950 \mathrm{~m}$. S. $11^{\circ}$ E. of Cerro de la Corona volcanic necle (sheet 1, quad. D-7). Basal beds of the Cuautla formation; of Turonian age. Reddish coquina and calcarenite formed largely of small silicified gastropods, within $5 \mathrm{~m}$. of the base of the Cuautla formation. Specimens examined by iN. I. Sohl were identified as two species of Nerinee, unlike any species described from Mexico or southern United States. F-6-54. Upland $300 \mathrm{~m}$. due east of Cerro de la Corona volcanic neck, west of $\mathrm{Km}$. 18 of the Cuernavaca-Cuautla highway (sheet 1 , quad. D-7). Upper part of the Morelos formation; of probable early Cenomanian age. Medium-gray Iimestone with irregularly silicified individuals of Toucasia patagiata(?) and abundant miliolids (refer to F-26-53 and $\mathrm{pl}$. 11-A), from within $35 \mathrm{~m}$. of the top of the Morelos formation. F-7-54. Refer to F-6-54, F-26-53, and pl. 12-B; F-12-54. Upland about $100 \mathrm{~m}$. northeast of Cerro de la Corona 
volcanic neck, due south of $\mathrm{Km}$. 16 of the CuernavacaCuautla highway (sheet 1 , quad. D-7). Middle part of the Cuautla formation; of late Turonlan age. Medium-gray, dense calcilutite with siliclfied individuals of a small thin species of Hippurites (not determined specifically) and a silicified specimen of Tetragramma(?) sp. The rudistid was examined by G. A. de Cserna, and the echinoid by C. W. Cooke.

F-15-54. Near the top of the spur $350 \mathrm{~m}$. due south of $\mathrm{Km}$. 20 of the Cuernavaca-Cuautla highway (sheet 1, quad. D-7). Top of the Morelos formation; of probable early Cenomanian age. Iight-gray to cream-colored dense calcilutite with abundant miliolids and two silicified individuals of the pelecypod senus Spondylua, from a few meters below the top of the Morelos formation. According to L. W. Stephenson, the specimens are unlike any described forms from the southern United States and may represent a new species. F-20-54. Base of the range $2000 \mathrm{~m}$. S. $68^{\circ}$ E. of the center of Emiliano Zapata (sheet 1, quad. D-7 and E-7). High in the livexcala formation; of probable post-Coniacian age. Hedium-gray, buff-weathering, shale interbeds in a dominantly calcareous sandstone sequence, from probably several hundred meters above the base of the llexcala formation, the locality being well out in the syncline. The sample was washed and examined in the paleontology laboratory of Petróleos Mexlcanos, the following foraminiferal genera 
being reported: Ammobaculites(?), Splroplectammina, Martinottiella, Gümbelina, Lamarckina, Valvulineria, Anomalina, and Clbicides. A part of the washed sample was examined and reported on by $R$. Todd, as follows: Planulina correcta (Carsey)(?), Haplophragmoldes (?) sp., Ammomarginulina(?) sp., and Gaudryina (?) sp.

F-21-54. Upland $3800 \mathrm{~m}$. S. $75^{\circ} \mathrm{E}$. of the center of Emiliano Zapata (sheet 1, quad. D-6 and E-7). Diabase sill in the Morelos formation; of probable early Tertiary age. Finely porphyritic rock with pllotaxitic to diabasic texture (pI. 20-C). Olivine phenocrysts up to $1.5 \mathrm{~mm}$. across are altered to nontronite(?) and calcite. Feldspar microlites up to $0.3 \mathrm{~mm}$. Iong are about $\mathrm{An}_{75^{\circ}}$ Matrix pyroxene is hypersthene and augite, iuch of which has been altered to nontronite(?). Iron ores form about 3 per cent of the rock. F-22-54. Upland spur $4700 \mathrm{~m}$. S. $79^{\circ} \mathrm{E}$. of the center of Tezołuca, on the west flank of Cerro Ectopan, east of $\mathrm{Km} .88$ of the new México-Acapulco highway (eastern one of two) (sheet 1 , quad. E-6 and E-7). Top of the lower one-third of the Cuautla formation; of Turonian age. Medium-gray, dense calcilutite and calcarente with abundant silicified Individuals of Radiolites sp. and Actaeonella sp. Examined by G. A. de Cserna.

F-23-54. Upland $5200 \mathrm{~m}$. due east of the center of Tezoyuca, east of $\mathrm{Km} .88$ of the new México-Acapulco highway (eastern one of two) (sheet 1, quad. E-6 and E-7). Near the base of 
the Cuautla formation; of Turonian age. Medium-gray, dense calcilutite with silicified individuals of Toucasia sp., Radiolites perforata Palmer, and Radiolites sp. Dissolution of the specimen in hydrochloric acid liberated a Toucasia with the small, llat, operculum-like right valve still attached. Radiolites was examined by G. A. de Cserna. (Cf. specimen F-34-50.)

F-28-54. South end of large quarry on the east side of Cerro Xiutepec, $2000 \mathrm{~m}$. south of the center of Xiutepec village (sheet I, quad. D-6). Basal part of the Mexcala formation; of early Coniacian age. Medium-gray, argillaceous calcarenite from about $10 \mathrm{~m}$. above the base of the Mexcala formation, contains abundant fish scales and specimens of Pithonella ovalis(?) and Calcisphaerula (?) sp. (ji. 15-A). F-29-54. Near the base of the range $1300 \mathrm{~m}$. due west of $\mathrm{Km}$. 43 of the Alpuyeca-Yautepec highway (sheet 1, quad. E-7). Well down in the Morelos formation; of probable middle Albian age.: Medium-gray, saccharoldal, recrystallized and dolomitized limestone, with calcite crystals up to $2 \mathrm{~mm}$. across. Some calcite has a poikilitic texture. No trace of fauna remains. Rock contains a few small grains of chert.

F-3I-54 and F-33-54. H1IIsIde $850 \mathrm{~m}$. due east of $\mathrm{Km}$. 5l, and $950 \mathrm{~m}$. S. $72^{\circ} \mathrm{E}$. of $\mathrm{Km}$. 50, respectively, of the AlpuyecaYautepec highway (sheet I, quad. D-8). Basal beds of the Cuautla formation; of Turonian age. Fine-grained conglom- 
erate and coarse-grained calcarenite beds making up the lowermost 5 to $10 \mathrm{~m}$. of the Cuautla formation, composed dominantly of subangular to well rounded limestone grains ranging from light cream to black, with a minor content of clastic dolomite and chert grains ( $p l .13-C$ and $-D$ ). The overall color of the beds is yellowish. Some grains are abraded miliolids eroded from the Morelos formation, and some larger grains enclose miliolids. Among 1dentifiable foraminifera are Quinqueloculina $\mathrm{sp.,} \mathrm{Nummoloculina}$ heimi Bonet, D1cyclina schlumbergerl vinier-Chalmas. Cementing matrix is clear calcite in crystals up to $1 \mathrm{~mm}$. across.

F-34-54. Arroyo bottom $450 \mathrm{~m}$. due west of $\mathrm{Km}$. 49 of the Alpuyeca-Yautepec highway (sheet 1 , quad. E-7). Iava from the Chichinautzin basalt series; of middle Pleistocene age. Porphyritic olivine basalt with granulitic matrix (pl. 22A). Olivine phenocrysts are up to $I \mathrm{~mm}$. across, are partly altered to lddingsite. Rock also contains olivine microphenocrysts. Feldspar microlites are about $\mathrm{An}_{75}$, are up to $0.6 \mathrm{~mm}$. long. Matrix contains abundant unaltered augite and about 2 per cent glass.

F-35-54. Valley $3600 \mathrm{~m}$. due east of $\mathrm{Km}$. 41.5 of the Alpuyeca-Yautepec highway (sheet 1 , quad. E-7 and E-8). Upper part of the Balsas clastic group; of probable early Oligocene age. Pink crystal-lithic rhyolite tuff with minor devitrified glass in the groundmass. Quartz crystals are up 
to $2.5 \mathrm{~mm}$. Iong, make up some 10 per cent of the rock. Biotite crystals are up to $1 \mathrm{~mm}$. Iong and make up some 5 per cent of the rock. Feldspars are mainly oligoclase, With less sanidine, and form about 10 per cent of the total rock. Tridymite occurs in the froundmass. Zircon is present as an accessory mineral. This tuff is interbedded with the upper part of the Balsas clastic group and was probably deposited from the air but was re-worked by water later.

F-36-54. Top of Cerro Amar1110, $4000 \mathrm{~m}$. due east of Tecumán and $\mathrm{Km}$. 39 of the Alpuyeca-Yautepec highway (sheet 1 , quad. E-7 and E-8). Well up in the Balsas clastic group; of probable early olisocene age. Reddish, very well cemented, limestone conglomerate with calcite matrix in crystals up to $1 \mathrm{~mm}$. across ( $\mathrm{pl}, 15-\mathrm{C}$ and $-D)$. Fragments are angular to rounded and derived mainly from the Morelos and Cuautla formations; but include rare lexcala cobbles. The reddish argillaceous component may be derived partly from weathered lexcala formation. Fragments range in size up to $20 \mathrm{~cm}$. or more, and the rock is generally well bedded but beds are poorly sorted. F-37-54. Highest point on highway between Tlaltizapán and Moyotepec, approximately $11 \mathrm{~km}$. due east of $\mathrm{km} .35$ of the Alpuyeca-Yautepec highway, east of the limit of the geology show on the map but included in the study (sheet 1 , quad. F-8). Upper part of the Morelos formation; of prob- 
able late Albian or early Cenomanian age. Brownlsh-gray, mottled, irregularly dolomitized and recrystallized calcarenite typical of interbeds in the Morelos formation in many parts of the area mapped; interbedded with foraminiferal limestone and biostromes containing Praeradiolites sp. and Toucasia patagiata(?) (pl. II-D).

F-41-54. Deep arroyo $700 \mathrm{~m} . \mathrm{N} .45^{\circ} \mathrm{W}$. of $\mathrm{Km}$. 38 of the AIpuyeca-Yautepec highway (sheet 1, quad. E-7). Well down In the Morelos formation; of probable middle Albian age. Well brecciated, grayish-brown dolomite with fragments up to $3 \mathrm{~cm}$. across, cemented by white to red-stained calcite (p1. 13-B). The rock is so massive that bedding is almost indistinguishable in outcrops as high as $30 \mathrm{~m}$. Similarly brecciated and re-cemented fine-grained dolomite occurs in thinner beds in many parts of the Morelos formation, producing a "pavement" surface in weathered outcrop. F-42-54. Quarry $500 \mathrm{~m}$. southwest of $\mathrm{Km}$. 38 of the AlpuyecaYautepec highway (sheet 1 , quad. E-7). Lava from Undifferentiated volcanic series; of middle Tertiary age. Darkreddish-brown porphyritic dacite(?) with pliotaxitic matrix (pl. 21-A). Contains sparse quartz and andesine phenocrysts up to $5 \mathrm{~mm}$. long, possibly as xenocrysts. Feldspar microlites are up to $1.2 \mathrm{~mm}$. Iong and are about $\mathrm{An}_{65} ;$ mafIc constituents have been altered largely to nontronite(?). Iron ores make up some 3 per cent of the rock. F-43-54. SmalI spur $200 \mathrm{~m}$. north of locality of F-42-54 
(sheet 1 , quad. 프-7). Lava from Undifferentiated volcanic series; of middle Tertiary age. This rock overlies eroded reddish clastic beds of the Balsas clastic group; it is similar to specimen F-42-54 (pl. 2l-c).

F-45-54. Small quarry $8000 \mathrm{~m}$. S. $28^{\circ} \mathrm{E}$. of the center of Tlaltizapán, $250 \mathrm{~m}$. east of the road (sheet 2, quad. F-7 and $G-7)$. Upper part of the Cuernavaca formation; of probable late Pliocene age. Honey-colored, calcareous gypsum from lenticular interbed in the Cuernavaca formation ( $p$. 18-D). Made up of irregularly rounded pellets of pure gypsum aggregates up to $10 \mathrm{~mm}$. across, in a lighter-colored matrix of finer-grained gypsum impregnated with calcite dust, which makes up perhaps 15 per cent of the rock. The gypsum crystals range from about 0.01 to $0.5 \mathrm{~mm}$, and the calcite dust is even finer in grain size. F-47-54. Arroyo meander scar 150 m. north of TlaltizapánMoyotepec highway, $3600 \mathrm{~m}$. due east of $\mathrm{Km}$. 34.3 of the Alpuyeca-Yautepec highway (sheet 1 , quad. F-7). Lower part of the Balsas clastic group; of probable early Oligocene age. Iight-gray, well cemented, fine-grained rhyolitic tuff interbed in reddish silt and clay beds of the Balsas clastic group. Tuff bed is only $10 \mathrm{~cm}$. thick and must have been deposited by water. Crystals are biotite, oligoclase, sanidine, and quartz, up to $0.3 \mathrm{~mm}$. across, making up more or less 15 per cent of the rock. All glass is devitrified. Rock looks much Iike specimen F-35-54. 
F-50-54. Scoria block from the south end of Cerro Temilpa, at the position of letter $F^{\prime}$ of section line $F-F^{\prime}$, erupted from El Chiquihulte volcano located about $1000 \mathrm{~m}$. due east of that point, beyond the east edge of the map (sheet 2 , quad. F-8). Basalt referred to the Chichinautzin basalt series; of Recent age. Porphyritic, hypocrystalline, olivine-augite basalt with pilotaxitic to intersertal matrix (pI. 22-D). Olivine and ausite phenocrysts are up to 1.2 m. Iong and make up about 10 per cent of the rock. Feldspar microlites range generally between 0.02 and $0.12 \mathrm{~mm}$. in length, are about $A n_{65}$, and occur with abundant augite grains. Iron ores make up about 2 per cent of the rock. All the minerals are fresh and unaltered. F-54-54. South end of Cerro Temilpa, about $600 \mathrm{~m}$. due west of the east end of section Iine F-F' (sheet 2, quad. F-8). Upper part of the Morelos formation; of probable late Alblan age. Medium-gray to Iight-creamy-gray, highly dolomitized calcarenite, from within $50 \mathrm{~m}$. of the top of the Morelos formation (pl. 10:D). Dolomite crystals pervade the rock irregulariy; calcite matrix has been recrystallized. F-64-54. Upland on low ridge $5500 \mathrm{~m}$. S. $47^{\circ} \mathrm{E}$. of the center of Tlaquiltenango, between 600 and $800 \mathrm{~m}$. due east of the road along the west base of the ridge (sheet 2, quad. $G-7$ ). Lower two-thirds of the Cuautla formation; of Turonian age. Chips from six beds between the lower contact of the Cuautla formation and about $60 \mathrm{~m}$. below the upper contact; these 
were judged in the field to range from the least dolomitized to the most dolomitized beds in the section. Tests by E. Schmitter gave the following percentages of dolomite in the chips: $0.0,0.9,1.2,1.7,49.0$, and 67.7 per cent dolomite. Insoluble residue tests of these samples gave, respectively: $4.3,0.9,0.6,7.8,3.4$, and 1.5 per cent insoluble.

F-65-54. Between the road cut at the base of the hill 7100 m. S. $36^{\circ} \mathrm{E}$. of the center of Tlaquiltenango, and the crest of the hill $900 \mathrm{~m}$. northeast of that point (sheet 2, quad. G-7 and $\underline{H-7}$ ). Upper part of the Morelos formation; of probable late Albian and early Cenomanian age. Chips from nine beds between the upper contact of the Morelos formation and possibly some $300 \mathrm{~m}$. stratigraphically below the contact; these were judged in the field to range from the least dolomitized to the most dolomitized beds in the sequence exposed. Tests by $\mathrm{E}$. Schmitter gave the following percentages of dolomite in the chips: 2.3, 22.5, 40.6, $50.6,63.8,75.5,78.8,81.6$, and 83.3 per cent dolomite. Insoluble residue content of these samples gave, respectively: $2.5,3.1,4.0,2.5,0.3,2.2,0.9,3.7$, and 2.8 per cent insoluble.

F-66-54. Hillside 1700 m. S. $74^{\circ}$ E. of Atlihuayán, measured from $\mathrm{Im} .53$ of the Alpuyeca-Yautepec highway (sheet 1, quad. D-8). Upper part of the Cuautla formation; of late Turonian age. Iight- to medium-gray, dense calcilutite 
Whth repeated mixed and alternating biostromes of Hippurites resectus var. mexicanus Bárcena, Radiolites sp., Durania cornu-pastoris, Actaeonella sp., and corals identified by J. W. Wells as belonging to the species Multicolumastraea cyathiformis (Duncan).

F-67-54. :H1llside 1000 m. S. $76^{\circ} \mathrm{E}$. of the center of Taxco Viejo (sheet 2, quad. I-I). Lower part of the Taxco viejo green volcanic series; of probable Late Triassic age. Greenish and purplish, weakly metamorphosed andesitic tuff and breccia from within $50 \mathrm{~m}$. of the underlying Taxco schist series. Fragments range from a few tenths of a millimeter to more than $3 \mathrm{~cm}$, consist of several varieties of porphyrItic andesite with amphibole and/or pyroxene (pl. 8-A and -B). Some have a chloritized matrix of devitrified glass; others are themselves made up of clastic volcanic rock. Chlorite and minor penninite pervade the rock and were developed largely as a result of dynamic metamorphism. Opaque Iron ores form about 5 per cent of the rock. Feldspars are unidentifiable. Calcite forms the cementing matrix and was recrystallized during metamorphism; 1ts great abundance suggests that the rock may be of marine pyroclastic origin. F-68-54. Ridge top about 2500 m. N. $68^{\circ}$ W. of Cuauchichinola (sheet 2, quad. $G-4$ and $\mathbf{E}-4$ ). Upper part of the Morelos formation; of probable late Albian age. Nearly black saccharoidal dolomitized limestone with veinlets of white calcite and chalcedony ( $p l$. 10-C). Rock consists of a mosaic 
of dolomite and calcite crystals from 0.2 to $1 \mathrm{~mm}$. across. Black color is probably due to bituminous or carbonaceous matter disseminated through the rock.

F-71-54. Road cut at $\mathrm{Km} .160 .5$ at the east edge of Taxco (sheet 2, quad. H-1). Near top contact of the Taxco schist series; of probable late Paleozolc age. Medium-gray, crenulated, sericite schist, well foliated, made up of grains of quartz and feldspar and dense fine-grained fragments composed of micro-crystalline quartz-feldspar-sericite aggregates ( $1.8+\mathrm{C}$ ); largest fragments are about $3 \mathrm{~mm}$. across. Some quartz grains are unstrained, embayed 1gneous crystals. Rock lacks ferromagnesian minerals, chlorite, and carbonaceous matter. It appears to represent a dynamically metamorphosed, crystal-Iithic rhyolite tuff.

\section{5}

F55-4. Hillside $2300 \mathrm{~m} . \mathrm{N} .18^{\circ} \mathrm{W}$. of the center of Jicarera (sheet 2, quad. G-6). Basal beds of the Cuautla formation; of Turonian age. Light-gray to yellowish, micro-conglomerate or calcarenite from within $3 \mathrm{~m}$. of the base of the Cuautla formation ( $\mathrm{pl}$. 14-A and $-\mathrm{B}$ ). Constituent grains are subangular to subrounded and range from a few tenths of a millimeter to $1.5 \mathrm{~mm}$; they consist of cryptocrystalIine dolomite or dolomitized limestone of light to dark color, set in a matrix of calcite crystals up to $0.5 \mathrm{~mm}$. across. Some grains contain microfossils, including Calci- 
sphaerula inominata (3), Quinqueloculina sp., Nummoloculina heimi, and other foraminifera up to $0.4 \mathrm{~mm}$. In diameter; Pithonella ovalis(?) may also be present. Fossils are poorly preserved, and some recrystallization of the dolomite and calcite has occurred, causing ragged edges to form around many grains. Host of the dolomite, however, consists of clastic grains eroded from the Morelos formation. F55-10. Road cut at $\mathrm{Km}$. I65 of the Taxco-Iguala highway (sheet 2, quad. $\underline{H}-1$ ). Lower part of the Mexcala formation; of early Coniacian age. Dark-gray, calcareous, carbonaceous, slightly follated siltstone interbed in a shalesiltstone-sandstone sequence ( $p I .18-E$ ). Rock is finely cross-bedded, consists of grains of quartz, limestone, feldspar, and highly altered mafic minerals. Calcite makes up about 40 per cent of the rock, partly as detrital limestone and partly as cementing matrix. Carbonaceous matter appears to be graphite. Very low grade dynamic metamorphism has caused development of a little chlorite and sericite, as well as recrystallization of the calcite matrix. No fossil remains were noted.

F55-11. Low ridge $900 \mathrm{~m}$. due west of the highway junction at the southeast end of Tequesquitengo Lake (sheet 2, quad. G-5). Upper part of the Morelos formation; of probable early Cenomanian age. Light-gray foraminiferal calcilutite replete with miliolids, from less than $50 \mathrm{~m}$. below the top of the Morelos formation. Study of thin sections by 
E. R. Applin revealed the presence of abundant individuals of the genera Quinqueloculina, Triloculina, Massilina, and Dicyclina, and less commonly Iituola(?) sp., Ammobaculites cf. A. cuyleri, and Cyclammina sp., amons other unidentifiable fragments.

F55-12. Upland 1350 m. N. $70^{\circ}$ W. of $\mathrm{Im} .95$ of the Cuermavaca-Amacuzac federal highway (western one of two) (sheet 1 , quad. E-6). Topmost beds of the Norelos formation; of probable early Cenomanian age. Light-gray dense calcilutite with miliolids and lerger fossil fragments, from within $10 \mathrm{~m}$. of the top of the Norelos formation. A siliclfied sponge was identified by J. W. Wells as Peronidella sp. cf. P. ramosissime Dunikowsky. Foraminiferal content was studied by E. R. Applin, who reported the following identifiable senera: dominant Quinqueloculina, Trilocul1na, Nassilina, and less abundant Dicyclina, Dulkhania, Guttulina, Lasena, Dentalina, Iftuola (?), Nummoloculina, and Bigenerina, as well as sections of ostracodes. F55-13. Upland 1800 m. N. $54^{\circ}$ W. of $\mathrm{Km}$. 95 of the Cuernavaca-Amacuzac federal highway (western one of two) (sheet 1 , quad. E-6). Basal beds of the Cuautla formation; of probable Turonian age. Yellowish to light-gray calcarenite from within a few meters of the base of the Cuautla formation, forming part of a thin sequence of clastic, detrital Iimestone beds below the normal denge limestone of the Cuautla formation. The rock contains algal structures 
identified by R. Rezak as follows: Dissocladella sp., Acicularia sp., Neomeris cf. N. cretacea, Boueing and/or Halimeda, Holosporella cf. H. Siamensis. A search for microfossils by R. C. Douglass showed the absence of millolids but the presence of the foraminiferal genus Cuneolina. F55-15. Near the base of the hill 1100 m. N. $25^{\circ}$ W. of the center of Cuauchichinola (sheet 2, quad. G-4). Upper part of the Morelos formation; of probable late Albian age. Dark-brownish-gray, partly dolomitized calcilutite with abundant fragments of rudistids, including Toucasia pataLiata(?); dolomitization is nearly confined to the rudistid shells, in contrast to a more common dolomitization of the matrix and silicification of the shell matter elsewhere in the region (pl. 10-B).

F55-16. Edge of the large sink $2300 \mathrm{~m} . \mathrm{N} .43^{\circ} \mathrm{E}$. of the center of Tilzapotla (sheet 2, quad. I-5 and $\underline{H}-5$ ). Well up in the Tilzapotla formation; of probable late oligocene or early Mocene age. Reddish-brown, fairly coarse grained, well indurated, extremely massive volcanic tuff-breccla, determined in thin section by $\mathrm{E}$. Schmitter to be composed of fragments of porphyritic rhyolite in a tuffaceous rhyolitic matrix.

F55-18. Hillside $1700 \mathrm{~m}$. S. $50^{\circ} \mathrm{W}$. of the road end at Xicotlacotla (sheet 2, quad. $\underline{-}-6$ ). Well up in the Mexcala formation; of probable coniacian age. Light-olive-green subgraywacke composed of grains generally smaller than $0.3 \mathrm{~mm}$. 
across, angular to subrounded, consisting of quartz, feldspar, chert, limestone, chloritized mafic minerals, and opaque iron ores. iratrix cement is largely calcite (pl. 18-A).

F55-19. Small hill at the east edge of the town of Amacuzac (sheet 2, quad. G-4). Lava from the basal part of the Buenavista volcanic series; of probable middle Tertiary age. Lavender aphanitic lava with rare andesine and quartz phenocrysts, up to $2 \mathrm{~mm}$. lons (pl. 2l-E), from less than $30 \mathrm{~m}$. above the underlying Tilzapotla rhyolite series. Phenocrysts may be xenocrysts, as the plagloclase seems to have a more calcic border than its center. Feldspar microlites are about $\mathrm{An}_{60}$ and are much altered to clays. Nafic minerals in the groundmass were probably hornblende but are now altered to chlorite, opaque iron ores, and clays. Glass in the matrix has a refractive index of about 1.49 , indicating a probable latitic composition. Sample was studied by both $E$. Schmitter and the writer. F55-20. Highway overpass just west of the town of Amacuzac, at the junction of the Taxco and Iguala highrays (sheet 2, quad. G-4). Dike cutting the Tilzapotla rhyolite series; of middle to late Tertiary age. Dark-gray, porphyritic, holocrystalline basaltic dike rock with pilotaxitic matrix (pl. 2l-D). Phenocrysts are amphibole, up to $1 \mathrm{~mm}$. lons, largely altered to iron ores and clays(?). Feldspar microlites are labradorite. Iron ores form about 5 per cent of 
the rock. Fine-grained matrix seems to be devitrified glass, contains tiny grains of augite(?); chlorite is rare. Sample was studied by both $E$. Schmitter and the writer.

F55-21. Road cut at $\mathrm{Km}$. 125.8 of the Amacuzac-Taxco highway (sheet 2, quad. $\underline{G}-4$ ). Lava interbedded with the Balsas clastic group; of probable early Oligocene age. Mediumgray, porphyritic, holocrystaline iddingsite(?) basalt with ophitic matrix, interbedded with reddish Iimestone conglomerate ( $p l .20-D)$. Olivine phenocrysts are altered to reddish-brow iddingsite( $(?)$, are up to $1 \mathrm{~mm}$. across. Feldspar microlites are up to $0.2 \mathrm{~mm}$. In length, are about $\mathrm{An}_{60}$, and are imbedded in an augite matrix. Nafic minerals are partly altered to chlorite, which also invades feldspars and fills fractures in the rock. Opaque iron ores form about 3 per cent of the rock. Studied by both E. Schmitter and the writer.

F55-22. State Iine $2600 \mathrm{~m}$. N. $58^{\circ} \mathrm{W}$. of $\mathrm{Km}$. 128 of the Amacuzac-Iguala toll road (sheet 2 , quad. H-3). Lava flow in the lower part of the Balsas clastic group; of probable late Eocene or early Oligocene age. Very dark gray, porphyritic, holocrystaline augite basalt with pilotaxitic matrix (pl. 20-F). Phenocrysts are augite clusters up to $1 \mathrm{~mm}$. across; hornblende xenocrysts(?) up to $0.7 \mathrm{~mm}$. Ions have reaction rims of tiny augite grains. Feldspar microIites are 0.2 to $0.5 \mathrm{~mm}$. long, consist of labradorite. 
Chlorite pervades the rock. Studied by E. Schmitter and the writer.

F55-24. Deep arroyo $2850 \mathrm{~m}$. due south of the east edge of Huajintlán, measured from $\mathrm{Km}$. 126.5 of the Amacuzac-Taxco highway (sheet 2 , quad. G-4). Lava interbedded with the upper part of the Balsas clastic group; of probable early Oligocene age. Nearly black, porphyritic, holocrystalline, olivine-hypersthene basalt with pilotaxitic matrix ( $p l$. 21-B). Phenocrysts make up about 10 per cent of the rock, consist dominantly of olivine that has been altered to 1ddingsite and then to serpentine, and less abundantly of hypersthene and bytownite. They range in size from 0.3 to $2.0 \mathrm{~mm}$. , but only the feldspar is over $1 \mathrm{~mm}$. Iong. Feldspar microlites consist of labradorite, are 0.1 to 0.5 mm. Iong, and occur with augite grains. Chlorite is common through the matrix and in fractures. Studied by $E$. Schmitter and the writer.

F55-26. Hilltop $2100 \mathrm{~m}$. due south of $\mathrm{Km}$. 133 of the Amacuzac-Taxco highway (sheet 2, quad. G-j). Small intrusive mass cuttins the Mexcala formation; of probable middle Tertiary age. Hedium-grayish-green, porphyritic, holocrystalline diabase with pilotaxitic matrix (pl. 20-A). Phenocrysts are 0.3 to $1 \mathrm{~mm}$. long, were originally augite but are now a mixture of opaque iron ores and chlorite. Feldspar microlites average about $0.1 \mathrm{~mm}$. In length, are near An6o, and occur with abundant grains of fresh augite and 
fewer prisms of hornblende(?). Apatite is common as an accessory mineral. Opaque iron ores form some 3 per cent of the rock. Chlorite pervades the matrix and fills fractures in the rock. Studied by E. Schmitter and the writer. F55-31. Ridge top about $2500 \mathrm{~m}$. due west of the center of Cuautlita, beyond the limit of the geology shown on the map (sheet 2, quad. E-4). Well down in the Horelos formation; of probable middle Albian age. Dark-gray, slightly dolomitized calcarenite, contains silicified and dolomitized fragments of rudistid shells, including Toucasia patagiata(?) (pl. 13-A). Both silica and magnesia replaced the calcitic shell matter and the calcilutite fill in some of the shells, in preference to the calcitic calcarenite matrix of the rock.

F55-33. Road cut $1800 \mathrm{~m}$. due west of the center of Emiliano Zapata (sheet 1 , quad. D-6). Lava interbedded with clastic beds of the Balsas clastic group, or possibly basal part of the overlying Undifferentiated volcanic series; of probable middle Tertiary age. Dark-reddish-brown, slightly porphyritic, holocrystaline basalt with pilotaxitic matrix (pl. 2l-F). Phenocrysts form less than I per cent of the rock, consist of olivine altered largely to opaque iron ores but preceded by iddingsite(?), are from 0.3 to $0.8 \mathrm{~mm}$. lons. Rare quartz grains are probably xenocrysts. Feldspar microlites are labradorite, from 0.2 to $0.7 \mathrm{~mm}$. Iong. liatrix contains augite grains and possibly also some hyp- 
ersthene. Chlorite has invaded the rock in minor quantity. Studied by E. Schmitter and the writer.

F55-35. Flank of arroyo $1700 \mathrm{~m}$. due north of $\mathrm{km} .122 .8$ of the Amacuzac-Taxco highway (sheet 2, quad. G-4). Small intrusive mass cutting the Balsas clastic group; of probable middle Tertiary age. Viedium-grayish-green, slightly porphyritic, holocrystalline diabase. Scattered phenocrysts were apparently augite but are now altered to iron ores and chlorite (pl. 20-B). Matrix feldspar microlites are labradorite and occur with fresh augite grains. Rock is well chloritized, much like specimen F55-26. F55-38. Ridge top $1750 \mathrm{~m}$. S. $17^{\circ} \mathrm{E}$. of the center of San Andrés de la Cal, on the north flank of Cerro Barriga de Plata (sheet 1, quad. C-7). Top of the Morelos formation; of probable early Cenomanian age. Iight-gray, very fine grained, foraminiferal calcarenite from within $10 \mathrm{~m}$. of the top of the Morelos formation ( $\mathrm{l} I$. II-B). Rock contains several genera of miliolids and other foraminifera and is characterized by abundant individuals of Nummoloculina heimi. It is not dolomitized. Compare with specimen F-19-52 (p1. 12-A).

F55-39. East flank of Cerro Barrifa de Plata, $3800 \mathrm{~m}$. N. $48^{\circ} \mathrm{E}$. of $\mathrm{Km}$. 16 of the Cuernavaca-Cuautla highway (sheet 1, quad. D-7). Upper part of the liorelos formation; of probable early Cenomanian age. Iight-gray, partly dolomitized, foraminiferal calcarenite from probably less than 
$50 \mathrm{~m}$. below the top of the Morelos formation (pl. 10-A). Rock contains miliolids and pellets composed of cryptocrystalline calcite, in a matrix of similar composition, but it is now largely replaced by dolomite. This specimen contrasts with specimen F55-15 (p1. 10-B) in which the fossils, and not the matrix, are replaced by dolomite.

F55-40. Quarry $1600 \mathrm{~m}$. IN. $28^{\circ} \mathrm{E}$. of the center of Oacalco (sheet 1, quad. C-8). Gypsum interbed in the Balsas clastic group; of probable late Eocene or early Oligocene age. Honey-colored gypsum with white to translucent chert nodule (pI. 18-F). The sypsum occurs in a mosaic of feathery twinned crystals or fibrous aggregates, generally less than $0.1 \mathrm{~mm}$. lons. The sillca occurs in tiny globular masses 0.1 to $0.3 \mathrm{~mm}$. across, composed largely of opal but partly crystallized to chalcedony. The chert nodule appears to be dense and nearly pure in hand specimen, but under the microscope it is seen to have a very fine grained gypsum matrix. No trace of fossils was noted. F55-42. Ridge top $2750 \mathrm{~m}$. S. $70^{\circ} \mathrm{W}$. of Hospltal, or top of second ridge west of Cuautla (sheet 1 , quad. E-9 and E-8). Upper part of the Cuautla formation; of late Turonian age. Iight-creamy-gray calcilutite with silicified corals and Toucasia sp., interbedded with layers containing Radiolites, Hippurites, and irregular chert nodules. The corals were identified by J. W. Wells as belonging to Columastraea n. sp. 
F55-43, A to H. Quarry $1100 \mathrm{~m}$. H. $23^{\circ} \mathrm{E}$. of the center of

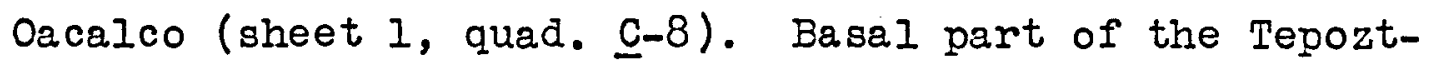
lán formation; of probable late Oligocene or early Miocene age. Series of 13 samples from large blocks of lava in the lower part of the Tepoztlán formation, representing the different types of material that make up the formation (pI. 19-A to -E). Beds are massive and constituents are poorly sorted, ranging from subangular to well rounded and from particles of clay size to boulders as much as $50 \mathrm{~cm}$. across; colors range from light to dark gray to greenish and reddish. Study of thin sections of these specimens by E. Schmitter led to the followins classification, in order from $A$ to $\mathrm{K}: \mathrm{A}$, hypersthene andesite; $B$, hornblende andesIte; $C$, hypersthene-augite andesite; $D$, hypersthene andesite; $E$, hornblende andesite; $F$, hypersthene-augite andesite; $G$, hornblende andesite; $H$, hypersthene-augite andesite; I, hornblende-pyroxene andesite; $J$, hypersthene(?) andesite; $K$, hypersthene-hornblende andesite; $I$, hyperstheneaugite-hornblende andesite; and $M$, hypersthene andesite. AlI these rocks contain andesine microlites, are porphyritic in varying degree, and have fine-grained to aphanitic Groundmasses. Marked differences in varleties and proportions of phenocrysts, textures, degree and kind of alteration, color, and grain size suggest that the lavas were erupted from several centers, although some of them may have come from the same eruptive center, there beins no way of 
proving the case one way or the other. They certainly show an overall genetic relationship. F55-48. Ridge top $6100 \mathrm{~m}$. due west of Casasano (sheet 1 , quad. D-9 and D-8). Upper part of the Cuautla formation; of late Turonian age. Light-gray calcilutite in alternating and mixed biostromes containing species of Hippurites, Toucasia, Radiolites, and lierinea, as vell as irregular chert nodules and lenses. Most of the fossils are silicified to a varying degree. Durania occurs more sparingly in nearby beds and is not silicified. Specimen consists of silicified gastropods, which are reported by N. F. SohI as belonging to Trochactaeon sp., somewhat similar to T. occidentalis but with more pronounced shoulders. 555-49. Old quarry at the base of the second range west of Cuautla, 6400 m. S. $80^{\circ}$ W. of the center of Cuautla (sheet I, quad. E-9 and E-8). Low in the liexcala formation; of early Coniacian age. Buff-weathering, gray shale interbeds In a siltstone-shale-sandstone sequence from within 10 or $15 \mathrm{~m}$. of the contact with the underlying cuautla formation. Semple was washed and examined by A. R. Ioeblich, Jr., who reported the presence of Globotruncana schneegans1. F55-52. Near the town of Placeres, Guerrero, about $100 \mathrm{~km}$. (airline) due west of the southernmost tip of the geologic map in plate 1 , or about $30 \mathrm{~km}$. southeast of locality 5 on the map in plate $3-A$; included here because of the pertinent information it provides. Placeres granite; of probable 
Cenomanian age. A radiometric age determination of a zircon concentrate by the lead-alpha method made by $H$. W. Jaffe and colleagures gave an age of 97 million years. The sample was collected and concentrated by $Z$. de Cserna and J. Pantoja-Alor.

F55-53. Hiliside $4800 \mathrm{~m}$. S. $53^{\circ} \mathrm{W}$. of the center of Cuautla, on the east flank of the first range west of Cuautle (sheet 1, quad. E-9). Topmost beds of the Horelos formation; of early Cenomanian age. Iight-gray foraminiferal calcarenite from within $3 \mathrm{~m}$. of the top of the Iiorelos formation. Examination of the specimen in thin section by E. R. Applin revealed the presence of abundant individuals of NummolocuIina heimi, Massilina sp., Massilina cf. M. planoconvexa, Dicyclina, Palmula cf. P. decorata, Priloculina, Quinqueloculine, and Ophthalmidiumsp., with rare sections of CuneoIina and ostracodes.

F55-58. Road cut $1100 \mathrm{~m}$. northeast of the point where the road intersects the west end of section line $A-A^{\prime}$ (sheet 1 , quad. (-5). Tepoztlán formation; of probable late Oligocene or early Hilocene age. Large blocks of medium-gray porphyritic, vesicular lava in coarse-grained clastic beds of the Tepoztlán formation. Two blocks were examined in this section by E. Schmitter, who identified the rock as hypersthene-augite andesite.

F55-59. Road cut at $\mathrm{Km}$. 13 of the highway to Zempoala Lakes (sheei 1 , quad. B-5). Lava flow in the Chichinautzin bas- 
alt series; of late Pleistocene age. Dark-gray porphyritic hypersthene basalt with occasional xenocrysts of plagioclase and quartz, both with reaction rims of pyroxene. Examined in thin section by $E$. Schmitter. F55-60. Road cut at $\mathrm{Km} .13 .9$ (State Iine) of the highway to Zempoala Iakes (sheet 1 , quad. B-5). Lava flow in the Zempoala andesite series; of probable late Miocene age. Medium-gray, porphyritic, holocrystalline andesite, with both hypersthene and augite. Accessory magnetite is abundant. Examined by E. Schmitter.

F55-6I. Outcrop at $\mathrm{Km}$. 88.9 of the Cuernavaca-Amacuzac federal highway (western one of two) (sheet 1 , quad. E-6). Lava referred to the Tilzapotla rhyolite series; of probable late Oligocene or early Mlocene age. Reddish porphyritic lava with an aphanitic matrix. Rock contains sanidine, quartz, oligoclase, hornblende, hypersthene, and magnetite, according to an examination by E. Schmitter, who classified it as a rhyo-dacite.

F55-62. Road-metal pit at $\mathrm{Km}$. 89.2 of the Cuernavaca-Amacuzac federal highway (western one of two) (sheet 1 , quad. E-6). Igneous rock either interbedded with the Tilzapotla rhyolite series or intruding it; of probable early Miocene age (if extrusive) or more recent (if intrusive). Irregular body of reddish-brown porphyritic rock with aphenitic matrix, not studied in detail and not mapped separately from the Tilzapotla rhyolite series. Examined by E. Schmit- 
ter, who reported the rock to contain andesine and hornblende and classified it as an andesite. F55-67. Hillside $350 \mathrm{~m}$. west of $\mathrm{Km}$. 185 of the Inexico-Acapulco highway, about $11 \mathrm{~km}$. beyond the south edge of the map (sheet 2 , south of quad. K-2); mapped in detail by 0 . Bohnenberger-Thomas (1955) and included here because of the pertinent stratigraphic information it provides. Upper beds of the liorelos formation; of early Cenomanian age. Medium-gray foraminiferal calcarenite from within $20 \mathrm{~m}$. of the top of the Horelos formation, contains miliolids, corals, and fragmental rudistids, including Toucasia patagiata $(?)$. The corals were identified by J.W. Wells as belonging to Epistreptophyllum sp. cf. E. budaensis Wells. The foraminifera vere examined in thin section by E. R. Applin, who identified the following genera and species: common to abundant Quinqueloculina sp., Dicyclina, and Cuneolina, and less common Lituola, a form related to Ovalveolina, Nummoloculina heimi, Massilina cf. M. planoconvexa, Palmula sp., Turrispirilina subconica(?).

F55-68. Quarry about $100 \mathrm{~m}$. west of $\mathrm{Km}$. 185 of the Acapulco hishway, about $11 \mathrm{~km}$. beyond the south edge of the map (sheet 2 , south of quad. K-2); mapped in detail by 0 . Bohnenberger-Thomas (1955) and included here because of the pertinent stratigraphic information it provides. Lower part of the Mexcala formation, of early Coniacian age. Light-gray, buff-weathering shale interbeds in a sequence 
of shale-siltstone-sandstone within $30 \mathrm{~m}$. of the base of the Mexcala formation, which here overlies the Morelos formation without the intervening Cuautla formation. Sample was washed and examined by A. R. Loeblich, Jr., who reported the presence of Globotruncana fornicata. F55-70. Road cut at $\mathrm{Km} .253$ of the Acapulco highway, near the tow of Hezquititlán (see pl. 3-A), about $80 \mathrm{~km}$. beyond the south edge of the geologic map in plate 1; mapped In detail by 0. Bohnenberger-Thomas (1955) and included here because fauna collected from these beds was described In detail by Burcliharut (1919, p. 93-130) and Böse (1923, p. 208-210) (refer to the description of specimen F-90-50, above). Lower part of the liexcala formation; of early Coniacian age. Ammonoids found were identified by R. W. Imlay as follows: Barroisiceras cf. B. haberfellnerl von Hauer, Scaphites aff. S. Eeinitzi D'Orbigny, otoscaphites aff. S. geinitzi Jahn, Otoscaphites aff. ‥ auritus Schlüter). Collected by the writer, 0 . Bohnenberger, and Z. de Cserna.

F55-77. Flank of a deep arroyo $2100 \mathrm{~m} . \mathrm{N} \cdot 78^{\circ} \mathrm{H}$. of $\mathrm{Km}$. 141 of the Amacuzac-Iguala toll road (sheet 2, quad. I-3). Upper part of the Xochicalco formation; of probable Aptian age. Dark-gray to bleck cryptocrystalline limestone with abundant dolomite rhombs and small patches of carbonaceous matter. Several chips were examined in thin section by $F$. Bonet, who reported the presence of abundant individuals of 
Rugoglobigerina sp., Colomiella mexicana, and silicified radiolaria.

F55-78. Road cut at $\mathrm{Km}$. 129 of the Amacuzac-Iguala toll road. (sheet 2 , quad. $\mathrm{H}-3$ ). Lower part of the Balsas clastic group; of probable late Eocene age. Dark-reddish-gray porphyritic iddingsite basalt with aphanitic groundmass. Phenocrysts are ollvine altered to reddish-brown iddingsite. Feldspar microlites are $\mathrm{An}_{65-70}$, generally 0.04 to $0.06 \mathrm{~mm}$. Iong; tiny dark-brown pleochroic needles of basaltic hornblende(?) are abundant. Opaque iron ores form about 5 per cent of the rock. Chlorite and nontronite(?) permeate the matrix.

F55-79. Base of hillside $1050 \mathrm{~m}$. N. $13^{\circ} \mathrm{W}$. of $\mathrm{Km} .144$ of the Amacuzac-Iguala toll road (sheet 2, quad. I-3). Basal beds of the Horelos formation; of probable late middle or early late Albian age. Medium-gray foraminiferal calcarenite from within $5 \mathrm{~m}$. of the contact with the underlying Xochicalco formation. Chips examined in thin section by $E$. R. Applin revealed abundant individuals belonging to Nummoloculina sp. ㅁ, Massilina cf. ㅍ. planoconvexa, and less commonly Cuneolina sp. The species of Nummoloculina in this sample differs markedly from the one that is characteristic of the upper part of the Morelos formation. F55-80. Road cut at $\mathrm{Km}$. 131.5 of the Amacuzac-Iguala toll road (sheet 2, quad. $\mathrm{H}-3$ ): Lower part of the Buenavista volcanic series; of probable liocene age. Darir-gray por- 
phyritic lava with aphanitic matrix; microphenocrysts consist of andesine, augite, and partly resorbed hornblende. Examined and classified by E. Schmitter as a dacite. F55-81. Road cut at $\mathrm{Km}$. 148.8 of the Amacuzac-Iguala toll highway (sheet 2, quad. I-3). Basal beds of the Niexcala formation; of possible latest Turonian or earliest Coniacian age. Creamy-gray calcilutite and biogenic calcarenIte with some detrital foraminifera eroded from weathered beds of the irorelos formation. Examination in thin section by $F$. Bonet revealed the presence of Gümbelina $\mathrm{sp}$. and abundant other foraminifera not identified generically and generally unknown from Mexican Upper Cretaceous rocks. F55-83. Road cut at In. 130.5 of the Amacuzac-Isuala toll road (sheet 2 , quad. H-3). Basal part of the Buenavista volcanic series; of probable lliocene age. Dark-gray, finegrained lava near contact with underlying limestone conglomerate of the Balsas clastic group; examined in thin section by $E$. Schmitter and classified as basalt. F55-84. Base of hillside $200 \mathrm{~m}$. due west of $\mathrm{Km} .141 .2$ of the Amacuzac-Iguala toll road (sheet 2, quad. I-3). Basic intmusive stock; of probable middle to late Tertiary age. Nearly black, dense, porphyritic isneous rock, contains both hypersthene and augite, together with andesine, and has a traquitic to pilotaxitic matrix. Examined in thin section by $E$. Schmitter and classified as an andesite porphyry. 
F55-85. Road cut at $\mathrm{Km}$. 122 of the Amacuzac-Iguala toll road (sheet 2 , quad. $\mathrm{H}-4$ ). Iower part of the Buenavista volcanic series; of probable Miocene ase. Dark-greenishGray porphyritic lava with andesine, hornblende, and biotite; matrix has a pilotaxitic texture. Examined in thin section by $E$. Schmitter and classified as an altered andesite (?).

F55-86. Upland $3400 \mathrm{~m}$. N. $70^{\circ} \mathrm{W}$. of $\mathrm{km}$. 142 of the Amacuzac-Iguala toll road, southeast of Coxcatlán (sheet 2, quad. I-3). Large intrusive stock cutting the Xochicalco and Morelos formations; of probable Cenomanian age, but possibly of early Tertiary age. Light-gray to pinisish, coarse-grained, porphyritic rock with quartz, orthoclase, albite, olifoclase, andesine, biotite, and hornblende, examined in thin section by $E$. Schmitter and classified as a granodiorite porphyry. This border phase is somewhat more calcic than the inner part of the intrusive body, Which is described under specimen F55-94.

F55-91. Along an old mine road about $2400 \mathrm{~m}$. S. $33^{\circ} \mathrm{W}$. of the center of Buenavista de Cuéllar, just beyond the limit of the seologic map (sheet 2 , quad. I-4 and $I-3$ ). Large intrusive stock cutting the Xochicalco and Horelos formations; of probable Cenomanien ase, but possibly of early Tertiary age. Hedium-gray, medium-grained, porphyritic igneous rock composed essentially of quartz, andesine, and diopside, examined in thin section by $E$. Schmitter and 
classified as a quartz diorite porphyry. This border phase shows the effect of the addition of lime from the Cretaceous Iimestone intruded, containing much epidote and garnet; the inner part of the mass is much less calcic. F55-92. Cliff along the road at $\mathrm{Km}$. 148.8 of the AmacuzacIguala toll road (sheet 2, quad. I-3). Top of the Horelos formation; of probable late Albian age. Medium-gray dense calcarenite from within $8 \mathrm{~m}$. of the contact with the overlyins formation, which is here the liexcala formation. Thin sections of several chips studied by $\mathrm{E}$. R. Applin revealed the presence of abundant sections of Nummoloculina $\mathrm{sp}$. (not N. heimi), Cuneolina sp., and species of lassilina, Guttulina, and Ophthalmidium.

F55-93. Deep arroyo $2000 \mathrm{~m} . \mathrm{S} .39^{\circ} \mathrm{E}$. of $\mathrm{Km}$. 154 of the Amacuzac-Iguala toll road (sheet 2 , quad. I-3). Upper part of the Xochicalco formation; of probable Aptian age. Very dark Gray, laminated, cryptocrystalline calcilutite with chert interleaves and carbonaceous matter; examination of several chips in thin section by $F$. Bonet revealed only calcified radiolaria.

F55-94. H1IIside $2250 \mathrm{~m} . \mathrm{N} .6 \mathrm{I}^{\circ} \mathrm{W}$. of $\mathrm{Km}$. 148 of the Amacuzac-Iguala toll road (sheet 2 , quad. I-3). Large igneous intrusive stock cutting the Xochicalco and lorelos formations; of probable Cenomanian age, but possibly of early Tertiary ase. Light-gray, coarse-grained, porphyritic isneous rock, examined in thin section by $E$. Schmitter, who 
reported the main constituents to be quartz, orthoclase, hornblende, and biotite, with magnetite and zircon as accessory minerals; the rock was classified as granite. This is part of the same intrusive mass described under specimen F55-86 and is here less calcic.

F55-95. Lower slope of the hillside $1800 \mathrm{~m}$. S. $65^{\circ} \mathrm{E}$. of Km. 153 of the Amacuzac-Iguala tolI road (sheet 2, quad. J-3). Large igneous intrusive body cutting the Xochicalco and Morelos formations; of probable Cenomanian age, but possibly of early Tertiary age. Medium-gray, fine-grained, porphyritic isneous rock, examined in thin section by $E$. Schmitter, who reported quartz, andesine, and biotite as major constituents and magnetite as the main accessory mineral; the rock was classified as granodiorite. F55-96. Road cut in the pass at $\mathrm{Km}$. 155.3 of the AmacuzacIfuala toll road (sheet 2, quad. J-3). Basal limestone bed of the Hexcala formation; of latest Turonian or earliest Coniacian age. Thin-bedded, creamy-gray, calcilutite from within $3 \mathrm{~m}$. of the contact with the underlying Morelos formation; several chips were examined in thin section by $F$. Bonet, who reported the presence of Pithonelia ovalis, Gümbelina sp., and Globiserine sp., as well as calcified radioIaria.

F55-97. Top of Cerro Colotepec, $2700 \mathrm{~m}$. N. $8 I^{\circ}$ W. of $\mathrm{Km} .91$ of the Cuernavaca-Amacuzac federal highway (western one of two) (sheet 1 , quad. E-6 and E-5). WeII dow in the Xochi- 
calco formation; of probable Iptian ase. Dark-gray to black, carbonaceous, partly recrystallized calcilutite, examined in thin section by $F$. Bonet, who reported the presence of abundant individuals of Colomiella mexicana and scarce specimens of Rusoglobigerina sp.

F55-99. Mine dump on the northwest flank of Cerro Colotepec, $3300 \mathrm{~m} . \mathrm{N} .72^{\circ} \mathrm{H}$. of $\mathrm{Km}$. 91 of the Cuernavaca-Amacuzac federal highway (western one of two) (sheet 1 , quad. E-6 and E-5). Small igneous stock intruded into the Xochicalco formation; of probable Cenomanian age, but possibly of early Tertiary age. Light-gray, coarse-grained, porphyritic igneous rock, examined in thin section by $E$. Schmitter, who reported the major constituents to consist of quartz, orthoclase, andesine, oligoclase, and biotite, with zircon as an accessory mineral; classified as porphyritic quartz monzonite.

F55-100. Railroad cut in the deep gorge $1900 \mathrm{~m} . \mathrm{N} .52^{\circ} \mathrm{E}$. of the center of EI Naranjo, measured from $\mathrm{Km}$. 189 of the Taxco-Iguala highwey (sheet 2, quad. J-2). Lower part of the Yorelos formation; of probable midale Albian age. MedIum-Eray, dense calcilutite or calcarenite with sparse fragmental foraminifera. Thin sections of chips studied by E. R. Applin revealed the presence of Iivmmoloculina sp. $\underline{b}$, abundant Spiroplectammina cf. S. Eoodlandana, common Iassilina cf. 1 . planoconvexa, and rare Dictyoconus (?). 555-104. Lower southeastern slope of Cerro Tuxpan, $2800 \mathrm{~m}$. 
N. $79^{\circ} \mathrm{E}$. of the center of the town of Tuxpan (sheet 2 , quad. I-3). Well down in the Xochicalco formation; of probable Aptian or Barremian age. Dark-gray to black, irregularly laminated, thin-bedded calcilutite with chert interleaves. Examination of thin sections of chips by $F$. Bonet revealed the presence of Rusoglobigerina sp., calcified radiolaria, and other unidentifiable fauna.

F55-106. Road cut $350 \mathrm{~m}$. due south of the southernmost tip of Lake Tuxpan (sheet 2, quad. J-3). Lava seemingly restins unconformabiy on the Balsas clastic group, and thus of probable middle to late Tertiary age; exact relationship was not studied and the rock unit was not mapped separateIy from the Balsas group. Black, fine-grained, dense, porphyritic lava classified on the basis of thin-section study by $E$. Schmitter as olivine basalt; contains olivine phenocrysts in a matrix of labradorite and augite microIites.

F55-107. Dike at the northwest edge of Tepecuacuilco and another dike about $2000 \mathrm{~m}$. northwest of there (sheet 2, quad. $\mathrm{K}-3)$. Dikes cut the Balsas clastic Group; probably of middle Tertiary ase. Specimens were examined in thin section by $E$. Schmitter, who reported that they consist of porphyritic igneous rock with hyalopilitic matrix. One contains essential quartz and andesine, but the other lacks quartz; mafic constituents are altered to serpentine, chlorite, and hydrated iron oxides. The rocks were classified 
as dacite and andesite, respectively.

\section{6}

F56-2. Base of the hill $800 \mathrm{~m}$. N. $7^{\circ} \mathrm{E}$. of the road junction at $\mathrm{Km}$. 142 of the Amacuzac-Taxco highway (sheet 2, quad. G-2). Lower part of the Xochicalco formation; of probable Aptian 25e. Dark-gray to black, generally dense calcilutite cut by calcite veinlets and containing leaves, nodules, and lenses of chert. Chips examined in thin section by $F$. Bonet revealed calcified radiolaria and RugoElobiserina sp.

F56-3. Upland $3500 \mathrm{~m}$. N. $6^{\circ} \mathrm{E}$. of the road junction at $\mathrm{Km}$. 142 of the Amacuzac-Taxco highway (sheet 2, quad. G-2). Well down in the iorelos formation; of probable middle Albian age. Very light gray to white calcarenite made up largely of biogenic fragments. Examination of chips in thin section by F. Bonet revealed the presence of Dictyoconus sp. and algal structures. F56-4. Hillside $950 \mathrm{~m}$. due east of the road junction at $\mathrm{Im}$. 142 of. the Amacuzac-Taxco highway (sheet 2, quad. G-2). Uppermost part of the Xochicalco formation; of probable Aptian age. Dark-gray, dense, partiy laminated calcilutite with chert nodules and lenses. Examination of chips in thin section by $F$. Bonet revealed the presence of RugoGlobigerina sp. and Colomiella mexicana.

F56-11. Low, flat hilitop $300 \mathrm{~m}$. N. $69^{\circ} \mathrm{W}$. of $\mathrm{Km}$. 179 of the 
Taxco-Iguala highway (sheet 2, quad. I-I). Topmost beds of the Norelos formation; of probable early Cenomanian age. Dark-gray dense calcarenlte with abundant foraminifera, from within $3 \mathrm{~m}$. of the contact of the lorelos formation with the overlying lexcala formation. Chips examined in thin section by E. R. Applin revealed the presence of Nummoloculine helmi, Quinqueloculina, several other miliolid genera, and a few fragments of Cuneolina sp. F56-12. Road cut at Km. 177.5 of the Taxco-Iguala highway (sheet 2, quad. I-I). Basal Iimestone beds of the liexcala formation; of probable latest Turonian or earliest Coniacian age. Black to dark-gray, thin-bedded, laminated calcilutite from within $30 \mathrm{~m}$. of the contact with the underlying Horelos formation. Examination of thin sections of several chips from the locality by $F$. Bonet revealed the presence of Globigerina(?) and other unidentifiable foraminifera.

F56-13. Road cut at Km. 177.3 of the Taxco-Iguala highway (sheet 2, quad. I-I). Basal Iimestone beds of the Miexcala formation; of probable latest Turonian or earliest Coniaclan age. Black, carbonaceous, laminated calcilutite from within $10 \mathrm{~m}$. of the contact with the underlying Horelos formation. Examination of thin sections of several chips from the locality by F. Bonet revealed the presence of GIObigerina sp. and parallelly oriented calcified radiolaria. F56-19. Road cut near El Ocotito, Guerrero, at $\mathrm{km} .323$ of 
the México-Acapulco hishway, about $30 \mathrm{~km}$. airline south of Chilpancinso, Guerrero (Iocality 3 in $\mathrm{pl}$. 3-A); about 115 $\mathrm{km}$. due south of the edge of the geologic map in plate I and included here because of the pertinent information it provides. El Ocotito granite, which intrudes the Horelos formation; of probable late Cenomanian age. A radiometric age determinstion of a zircon concentrate by the lead-alpha method, made by H. W. Jaffe and colleagues, gave an age of 92 milifion years. The sample was collected and concentrated by $\mathrm{Z}$. de Cserna and J. Pantoja-Alor. F56-20. Road cut near Xaltiansuis, Guerrero, at $\mathrm{Im} .360$ of the México-Acapulco highway, about $37 \mathrm{~km}$. airline southwest of EI Ocotito (see description of specimen F56-19 and $\mathrm{pI}$. $3-A)$; about $140 \mathrm{~km}$. south-southwest of the edge of the geolosic map in plate $I$ and included here because of the pertinent information it provides. Xaltianguis granite; of probable late Cenomanian age. A radiometric ase determination of a zircon concentrate by the lead-alpha method, made by H. W. Jaffe and colleagues, gave an age of 94 million years. The sample was collected and concentrated by $z$. de Cserma and J. Pantoja-AIor.

F56-21. Road cuts at the north edge of Acapulco, port on the Pacific Ocean about $165 \mathrm{~km}$. by airline south-southwest of the edge of the geologic map in plate 1 (see pl. 3-A); included here because of the pertinent information it provides. Acapulco granite; of probable late Cenomanian age. 
A radiometric ase determination of a zircon concentrate by the lead-alphe method, made by H. W. Jaffe and colleagues, gave an ase of 94 million years. The sample was collected and concentrated by $Z$. de Cserna and J. Pantoja-AIor. F56-27. Road cuts at $\mathrm{Km}$. 129.5 of the Amacuzac-Taxco highway (sheet 2 , quad. G-3). Tuff from the Tilzapotla rhyoIite series; of probable late Oligocene or early Miocene ase. A radiometric age determination of a zircon concentrate by the lead-alpha method, made by H. W. Jaffe and colleagues, gave an age of 28 million years (limits of error may exceed 10 per cent), which is near the Olisocenelilocene boundary.

S56-16 to $556-18$ and $556-24$. Along the old lossing railroad grade about $4 \mathrm{~km}$. N. $20^{\circ}$ to $30^{\circ} \mathrm{E}$. of Cerro Chichinautzin, and $7.5 \mathrm{~km}$. N. $70^{\circ} \mathrm{E}$. of Cerro Chichinautzin (556-24), beyond the northern limit of the geology show in plate 1 (sheet 1 , quad. $\mathbf{A}-7$ and $\underline{A}-8$ ). Iava from Cerro Chichinautzin, part of the Chichinautzin basalt series; of Recent ase. Porphyritic olivine basalt with pilotaxitic to hyalopilitic matrix; contains sparse corroded quartz xenocrysts with reaction rims of augite. Examined in thin section by $E$. Schmitter; collected by Schmitter and the writer. S56-19 to S56-23. Alons the old losging rallroad grade between the two points cited under S56-16 to $556-18$ and $556-24$, above, beyond the northern limit of the geology show in plate $I$ (sheet 1 , quad. $A-7$ and $\underline{A}-8$ ). Lava from different 
volcanoes, part of the Chichinautzin basalt series; of late Pleistocene age. Examined in thin section by $E$. Schmitter and classified as hypersthene basaltic andesite, enstatite basalt, olivine-ausite basalt, olivine basalt with intersertal texture, and olivine basalt, respectively. Collected by Schmitter and the writer.

S56-25 to $556-27$. Along the old lossins railroad grade between points $7.5 \mathrm{~km}$. N. $70^{\circ} \mathrm{E}$. of Cerro Chichinautzin and $7 \mathrm{~km}$. S. $85^{\circ} \mathrm{E}$. of Cerro Chichinautzin, beyond the northern Iimit of the geology show in plate 1 (sheet 1 , quad. A-8). Lava from different eruptive centers, part of the Chichinautzin basalt series; of late Pleistocene age. Identified in thin section by $E$. Schmitter as olivine basalt in each case. Collected by Schmitter and the writer. S56-28. Road cut near Km. 33 of the liéxico-Cuernavaca toll highway, just beyond the northern limit of the seology show in plate $I$ (sheet 1 , quad. A-6). Lava assigned to the Chichinautzin basalt series; of late Pleistocene age. Identified in thin section by $E$. Schmitter as olivine basalt; collected by Schmitter and the writer. S56-29 to S56-31. High lava front from $1100 \mathrm{~m}$. to $3100 \mathrm{~m}$. S. $53^{\circ}$ V. of Cerro Tuxtepec (sheet I, quad. A-5). Lava assigned to the Chichinautzin basalt series; of Recent age. Highly viscous, dome-like extrusion of medium-gray to reddish porphyritic lava, identified by $E$. Schmitter as hypersthene-hornblende andesite. The rock contains xenocrysts 
of oligoclase-andesine; hypersthene phenocrysts have reaction rims of hornblende needles. Collected by Schmitter and the writer.

\section{$\underline{1957}$}

F57-35. Road-metal pit north of the road at the northwest entrance to Tlaquiltenanso (sheet 2 , quad. $G-7$ ). Uppermost part of the Cuernavaca formation; of probable late PIiocene or early Pleistocene age. Calcareous, tuffaceous, argillaceous, poorly indurated silt interbed in the topmost part of the Cuernavace formation; sample contains diatoms.

F57-42. Junction of the Taxco-Cacahuamilpa-Toluca highway With the Cacahuamilpa-Alpuyeca highway at Cacahuamilpa, about $2.5 \mathrm{~km}$. beyond the edge of the geologic map (sheet 2, quad. F-3), due north of $\mathrm{Km}$. 138 of the Amacuaac-Taxco highway. Lowermost beds of the liexcala formation; of probable late Turonian age. Thin-bedded, dark-gray, highIy calcereous and carbonaceous siltstone or silty calcilutite from within $3 \mathrm{~m}$. above the contact with the thickerbedded, dense calcarenite; contains very sparse and poorly preserved microfauna, which was studied in thin section by E. R. Applin and ldentified as consistins of Praeglobotruncana delrioensis (?), Gümbelina (?) sp., Globigerina(?) sp., and possibly stomiosphaera(?).

F57-43. Junction of the Taxco-Cacahuamilpa-Toluca highway 
with the Cacahuamilpa-Alpuyeca highway at Cacahuamilpa, about $2.5 \mathrm{~km}$. beyond the edge of the geologic map (gheet 2, quad. E-3), due north of $\mathrm{Km}$. 138 of the Amacuaac-Taxco highway. Topmost beds of the Cuautla formation, of probable Turonian age. These beds are somewhat different in facies from the normal Cuautla formation in the area mapped because they lack the characteristic macrofauna. The microfauna is distinct from that of the underlying worelos formation, however; it was studied in thin section by $E$. R. Applin, who ldentified the following forms: Planulina sp. close to Planomalina opsidostroba Loeblich and Tappan, Ammotium braunsteini(?) (Cushman and Applin), Ammobaculites sp. close to A. cuyleri Tappan, small lassilina, small and large Quinqueloculina, Triloculina sp., small Globotruncana (?), and fragments of Cuneolina(?) or Dicyclina(?). F57-44. Road cut just under basalt on old road from macatlán to Palpan and Chalma, about $300 \mathrm{~m}$. east of Palo Grande, or $7 \mathrm{~km}$. N. $42^{\circ} \mathrm{w}$. of $\mathrm{Km}$. 14 of the AIpuyeca-Cacahuamilpa highway at the northeast edse of Iijacatlán (sheet I, quad. E-4); beyond the limit of the geology shown in plate 1 , but included here because of the pertinent information it provides. From about $150 \mathrm{~m}$. above the base of the Mexcala formation; of Coniacian aEe. Hedium-gray shale interbeds in a calcareous shale-siltstone-sandstone sequence in the lower part of the formation; sample was washed and studied by $F$. Bonet and colleasues, who reported the followins 
fauna: Globotruncana lapparenti Bolli, Globotruncana rosetta (Carsey), Globotruncana sp., and Globigerina sp. F57-48. Quarries at $\mathrm{Km} .153$ of the Amacuzac-Taxco highway, on the west side of the road (sheet 2, quad. $\mathrm{H}_{-2}$ ). BasaI part of the Tilzapotla rhyolite series; of probable late Oligocene or early Miocene age. Black "pitchstone" composed of andesite fragments and fayalite, diopside, and andesine crystals, set in a partly devitrified welded dacitic glass; matrix is made up of welded, collapsed shards and pumice fragments with a refractive index of about 1.51 and containing by enalysis 69 per cent silica (pI. 8-E; pI. 9-C and $-E$ ). Examined by C. S. Ross and the writer. F57-49. Quarries at $\mathrm{Km}$. 153 of the Amacuzac-Taxco highway, on the west side of the road (sheet 2, quad. H-2). Basal part of the Tilzapotla rhyolite series; of probable late Oligocene or early Iilocene ase. Reddish-brown to lightbrom, mottled, dense, devitrified welded dacitic tuff from a layer 10 to $15 \mathrm{~m}$. thick above the "pitchstone" described under specimen F57-48 (p1. 9-B). Phenocrysts are andesine, up to $I \mathrm{~mm}$. In length, and deep-brown altered augite(?) or pigeonite(?), together with much opaque iron ores. Dark lentils are fan-like feldspar asgregates in a lighter-colored devitrified matrix. The rock may be andesite or dacite.

F57-50. Quarries at Im. 153 of the Amacuzac-Taxco hightay,

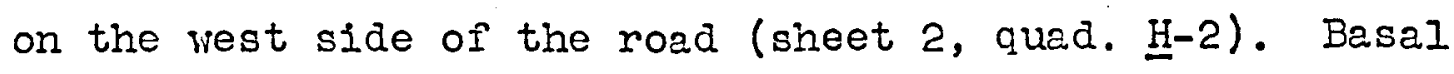


part of the Tilzapotle rhyolite series; of probable late olisocene or early Hiocene age. Dark-pink, coarse-grained, dense, almost totally devitrified welded rhyolite tuff. Phenocrysts make up about 40 per cent of the rock, consist of quartz, andesine, sanidine, and biotite, with opaque grains of iron ore which may have been augite (pI. 8-E and p1. 9-D and $-F)$. Shards are compressed and conform to the outlines of the phenocrysts and lithic fragments. Quarta crystals are up to $3 \mathrm{~mm}$. long, and biotite is as long as $0.5 \mathrm{~mm}$.

F57-58. River bed $600 \mathrm{~m}$. If. $72^{\circ} \mathrm{E}$. of Taxco Viejo (sheet 2, quad. I-I). Taxco schist series near an unconformable contact with the overlying liexcala formation; of probable late Paleozolc age. Light-gray, fine-grained, dense sericitic schist ( $p 1$. 8-D and pl. 9-A). Natrix consists of sericite with finely crystallized feldspar, contains scattered twinned plagioclase crystals, possibly oligoclase, as well as embayed and roundish quartz srains, but no recognizable mafic constituents except possibly iron ores. A made "bedding" cuts across the foliation at an angle of $20-25^{\dot{0}}$ and may represent the original stratification. The rocls also contains irregular elongated lentils of cryptocrystalline quartz-feldspar aggregates up to $I \mathrm{~mm}$. Iong. It was probably originally a fine-grained crystal-lithicvitric rhyolite tuff. Compare with specimen F-71-54. 
List of samples collected from the rock formations in the area mapped and cited in the text

\begin{tabular}{|c|c|c|c|c|c|}
\hline $\begin{array}{c}\text { Taxco } \\
\text { schist } \\
\text { series }\end{array}$ & $\begin{array}{l}\text { Taxco Vie- } \\
\text { jo green } \\
\text { volcanic } \\
\text { series }\end{array}$ & $\begin{array}{l}\text { Xochicalco } \\
\text { formation }\end{array}$ & $\begin{array}{l}\text { Morelos } \\
\text { formation }\end{array}$ & $\begin{array}{l}\text { Cuautla } \\
\text { formation }\end{array}$ & $\begin{array}{l}\text { Mexcala } \\
\text { formation }\end{array}$ \\
\hline $\mid \begin{array}{l}F-71-54 \\
F 57-58\end{array}$ & F-67-54 & $\begin{array}{r}r 55-77 \\
93 \\
97 \\
104 \\
556-2 \\
4\end{array}$ & $\begin{array}{c}F-5-50 \\
18 \\
25 \\
38 \\
F-19-52 \\
F-25-53 \\
26 \\
27 \\
28 \\
F-6-54 \\
7 \\
15 \\
29 \\
37 \\
41 \\
54 \\
65 \\
68 \\
\text { F55-11 } \\
12 \\
15 \\
31 \\
38 \\
39 \\
53 \\
67 \\
79 \\
92 \\
100 \\
\text { F56-3 } \\
11\end{array}$ & $\begin{array}{c}\text { F-12-50 } \\
13 \\
22 \\
23 \\
34 \\
44 \\
45 \\
63 \\
83 \\
\text { F-23-53 } \\
\text { F-4-54 } \\
12 \\
22 \\
23 \\
31 \\
33 \\
64 \\
66 \\
\text { F55-4 } \\
73 \\
42 \\
48 \\
\text { F57- } 43 \\
\\
\vdots \\
\vdots\end{array}$ & $\begin{array}{c}\text { F-20a-50 } \\
21 \\
33 \\
53 \\
57 \\
59 \\
60 \\
61 \\
67 \\
68 \\
90 \\
91 \\
92 \\
\text { F-1-53 } \\
2 \text { to } \\
15 \\
17 \\
18 \\
22 \\
\text { F-20-54 } \\
28 \\
\text { F55-10 } \\
18 \\
49 \\
68 \\
70 \\
81 \\
96 \\
\text { F56-12 } \\
13 \\
\text { F57-42 } \\
44\end{array}$ \\
\hline
\end{tabular}


Ilst of samples collected from the rock formations in the area mapped and c1ted in the text--Continued

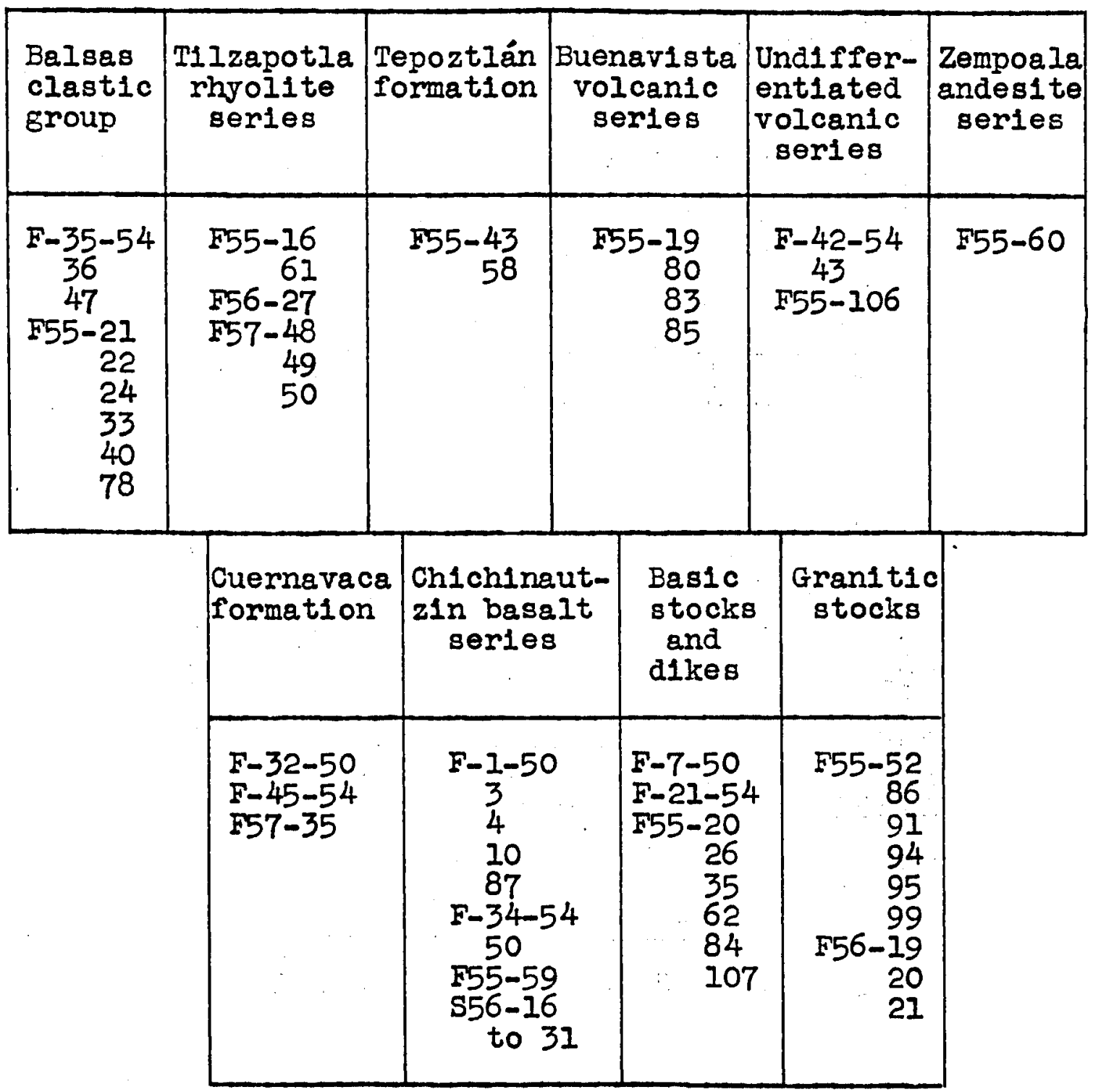




\section{METRIC EQUIVALENTS}

TEMPERATURE

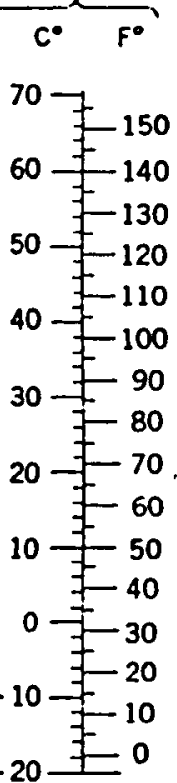

LINEAR

MEASURE

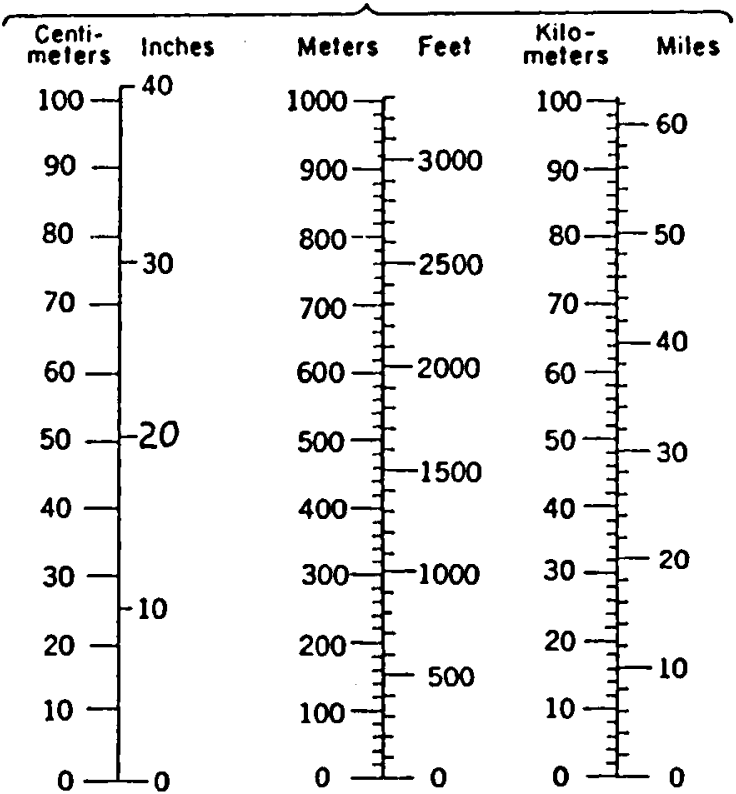

$1 \mathrm{~cm}=0.3937 \mathrm{in} . \quad 1 \mathrm{~m}=3.2808 \mathrm{ft} . \quad 1 \mathrm{~km}=0.6214 \mathrm{mile}$ $l_{\text {in }}=2.5400 \mathrm{~cm}, \quad \mathrm{ft}_{t}=0.3048 \mathrm{~m} . \quad$ Imile $=1.6093 \mathrm{~km}$.

I sq. m. $(\mathrm{m} 2)=1.20$ sq. yd.

I heclare $(100 \times 100 \mathrm{~m})=2.47$ ocres

l cu.m. $(\mathrm{m} 3)=1.31 \mathrm{cu} . \mathrm{yd}$.
WEIGHTS

Kilo- $\begin{gathered}\text { Pounds } \\ \text { (avoir) }\end{gathered}$ Metric Long
lons lons


310

PLATES 4 THROUGH 22 
PLATE 4

311 
PLATE 4

OELIOUE TRIEETROGON AIR PHOTOGRAPH LOOKIHG N. $33^{\circ}$ E. FROM $A$ POSITION ABOUT $4 \mathrm{KM}$. SOUTH OF THE ANACUZAC RIVER

Note the three lakes-Tequesquitengo, Coatetelco, and EI Rodeo--that occupy poljes in the Cuernavaca formation, of PI1ocene age; the poljes were formed by solution of the underlying calcareous Cretaceous rocks. The Amacuzac River, in the lower right corner of the photograph, has an altitude of about $835 \mathrm{~m}$. above sea level, in contrast to PopocatépetI Volcano in the upper right comer, which rises to $5452 \mathrm{~m} ; 81 \mathrm{v}$ ins a total relief of $4617 \mathrm{~m}$. The rldge from Popocatépet westwara to Cerro zempoala conolats of the Chlchinautzin basalt aerles, of Plelstocene age, which cuts off drainage from the north and formed the endorelc lexico Basin. Cerro Chichinautzin has an altitude of $3476 \mathrm{~m}$. and 18 one of the high pears in the Ple1stocene lieo-volcanlc Belt that traverses Iex1co from west to east at this latitudo. The foreground of the photograph $11 \mathrm{es}$ south of the volcanic belt, and the Nexico Easin (beyond Cerro Chichinautzin) lies in the northern part of the belt. This volcanic belt, mainly of Plo1stocene ase, here foring the southern border of the Hexican Highlands end the northern border of the Balsas Basin phys10Eraphic province, of which the area mapped forms a part. (Fhotograph taken by the U. S. Alr Force. For comparison, refer to the geologlc map in plate l.) 
PLATE 4

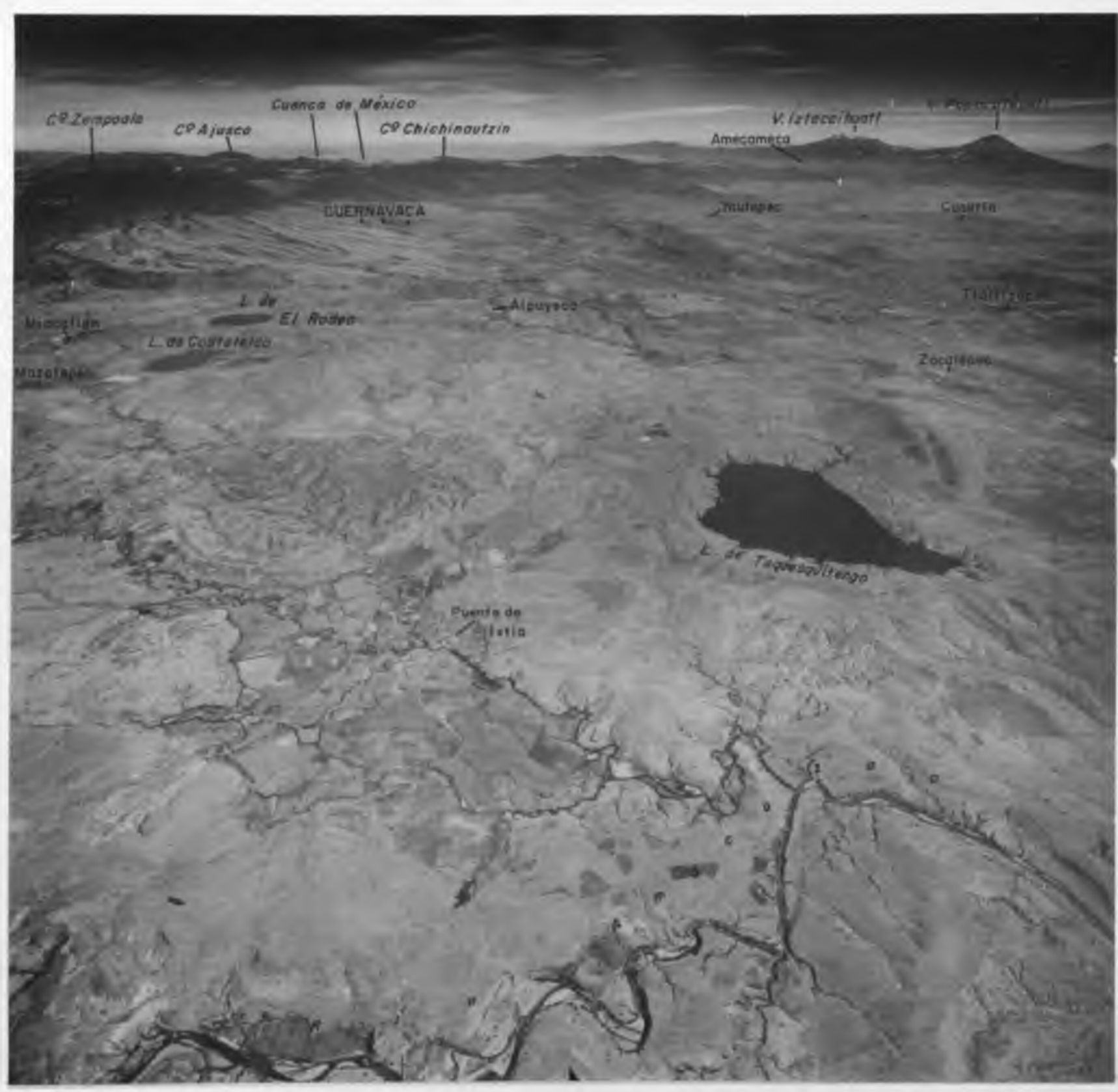


PLATE 5

312 


\section{IIINE 5}

OBLIRUE TRIYTIROGON $\Lambda$ IR PHOTOGRAPH LOOKING IN. $33^{\circ}$ E. FROIN $\triangle$ FOSITIOH ABOUT 4 KI. SOUTH OE XICOTLACOTLA ON THE AMACUZAC RIVER

The altitude at the junction of the Amacuzac and Chinameca Rivers 18 about $775 \mathrm{~m}$., in contrast to the top of PopocatépetI Volcano, which is $5452 \mathrm{~m}$. above sea level. The hilis between the Amacuzac River and the c1ty of Cuautla, to the northeast, are composed largely of Cretaceous rocks. (For seologic deta11s, refer to the geologic map in plate $I$ and the stmacture sections in plate $3-B$. Fhotograph taken by the U. S. Air Force.) 
PLATE' 5

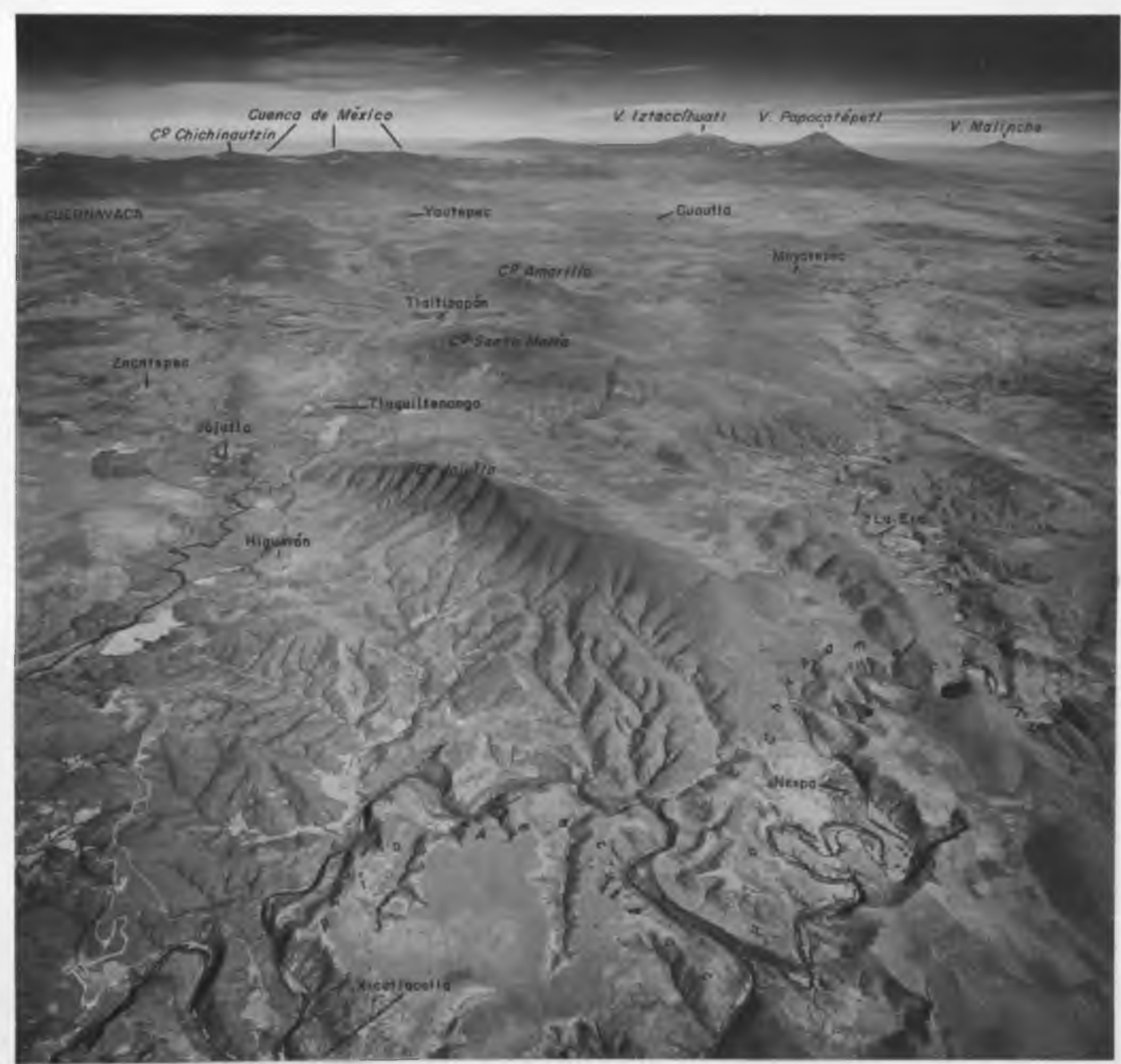


PLATE 6 


\section{PLATE 6}

OBLIQUE TRIIITROGON AIR PHOTOGRAPH LOOKING S. $33^{\circ} \mathrm{W}$. FRON A FOSITION ABOUT 5 KL. NORTH OF SANTA FE ALONG THE MIACUZAC-IGUALA TOLI ROAD

The toll road Eenerally mariss the zone of contact between the rounded hills of Cretaceous rocks on the right, and the clastic and volcanic rocks of Cenozoic ase on the left. This resion drains southward to the great Balsas River, which lies on the near side of the mountain ranse on the horizon and is orlented east-west. The mountains form the northern part of the sierre Wadre del sur, which Iles south of the Balsas RIvor. The river flows westward to the Guerrero-lichoacán state boundary line, where it turns sharply southvard and emptles directiy into the Pacific Ocean. (For seolog1c detalis, refer to the Eeologic and structure maps in plates $I$ and $3-B$. Photograph taken by the U. S. (ir Force.) 
PLATE 6

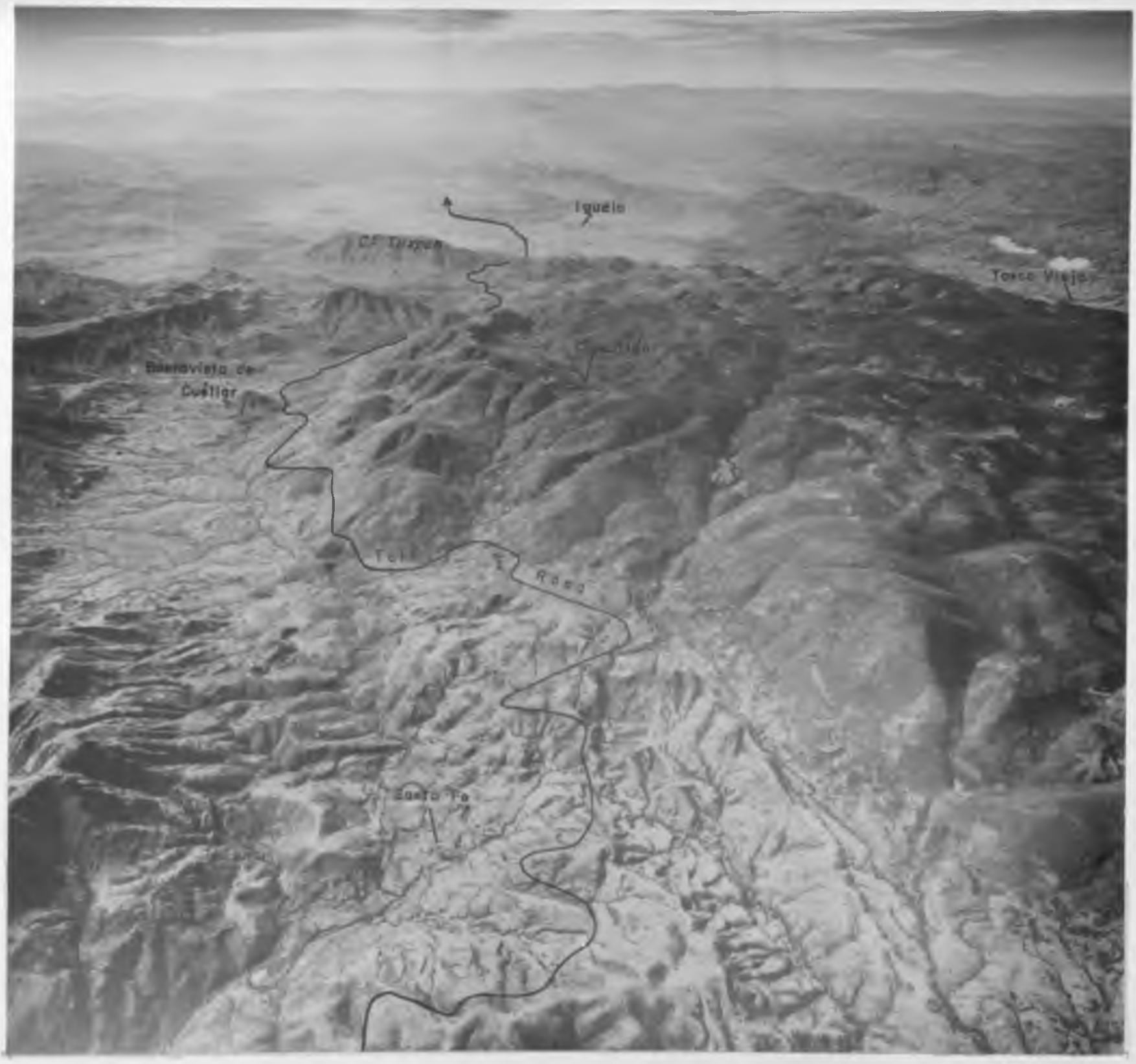


314

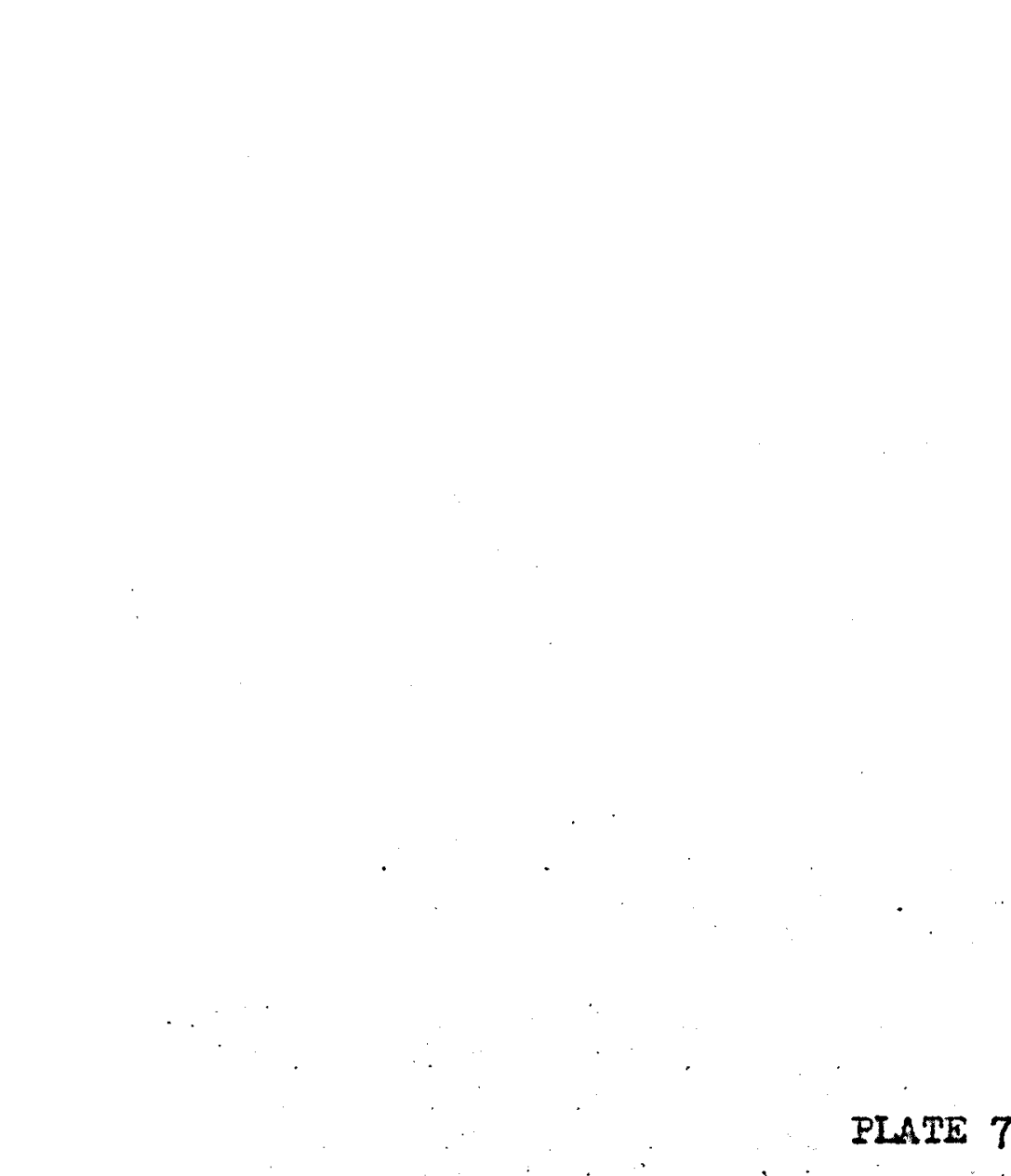

\section{PLATE 7 \\ LAT 7}

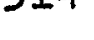




\section{PIATE 7}

OBLIQUE TRIIETROGON AIR PHOTOCRAPH LOOKIING $5.33^{\circ}$ W. FROM $A$ POSITION $\triangle B O U T$ T $\mathrm{EH}$. HORTH OF ACUITLAPIN

ON THE AHACUZAC-TAXCO HIGHWAY

The rounded hills on the left are composed of Cretaceous I1mestone; the right side of the photogreph, from the foreground to as far south as Taxco, consists of Tertiary clastic and volcanic rocks. Beyond Taxco are folded Lower and Upper Creteceous rocks of the rorelos and lexcela formations. Drainage from this entire region is southward to the great westflowing Balsas River, which lies on the near side of the mountain ranse on the horizon, which is the northern part of the Slerra ladre del Sur. This resion is part of the Balsas Easin physiographic province. (For geologic details, refer to the elologic and structure naps in plates $I$ and $3-B$. Fhotosraph taken by the U.S. A1r Force.) 


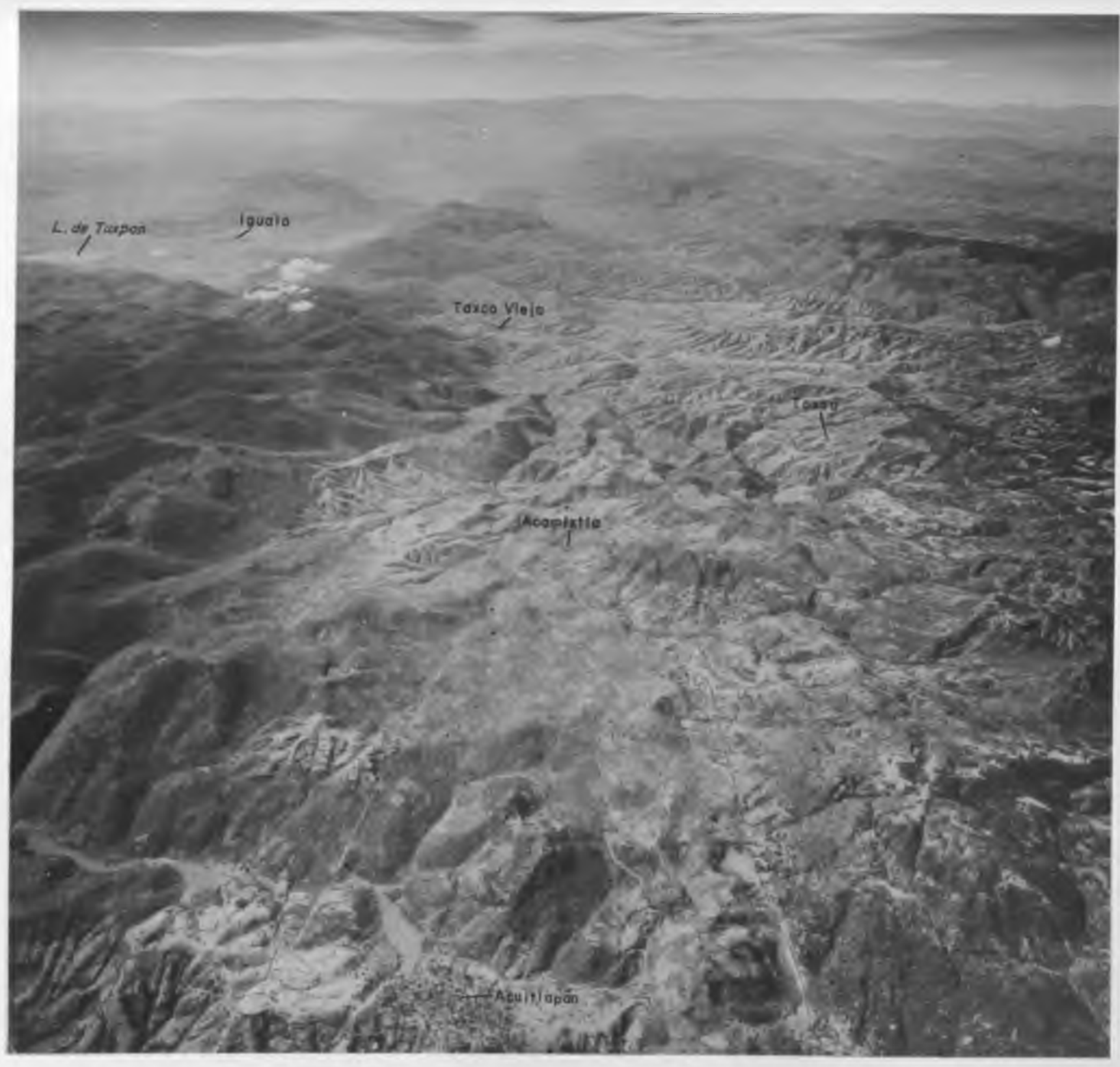




\section{PINTE 8}


PHOTONICROGRAPHS OF LOW-GRADE SCHISTS AND VEIDED TUFES

$A$, Chloritized calcitic andesite greenstone from the Taxco Viejo green volcanic series. Original rock was probably a coarse-grained, andesitic, lithic tuff. Tuffaceous and 11thic fragnents are compressed and calcite is recrystall1zed; these features and development of chlorite indicate a very low Erade of dynemic metamorphiam. High calcite content of matrix sugesests marine deposition. Specimen F-67-54; planepolarized Iight.

$B$, Rock from same formation as $A$, but finer in Grain size and With Ereater proportion of calcite (Ilght matrix). Specimen F-67-54; plane-polarized 11ght.

C, Iov-Grade sericltic schlst from the Taxco schist series. Note rolict embayed igneous quartz crystal in upper left corner of photograph. Rock appesrs to be made up of lithic fragments and some quartz and feldapar crystals, suegestins that it was originaily a crystal-lithic rhyolite tuff. Dark veinlet consists of supergene hydrous iron oxides. Specimen F-71-54; plane-polartzed light.

$D$, Vexy fine grained sericitic schist from the Taxco schist series. Note embayed quartz crystal in lower right corner of photosraph. A faint beddine appears to form a $20^{\circ}$ angle with the schistosity. Orisinal rock vas probably a fineerained rhyolite tuff. Specinen F57-58; plane-polarized Iight.

I, Devitrified, welded, coarse-grained, crystal-11thic-vitric rhyolite tuff from the Tilzapotla rhyolite series. Shards and purice fragments are collapsed and bent around crystals and 11thic fragments. Specimen F57-50; plane-polarized light.

F, Black "pitchstone", or velded, crystal-lithic-vitric dacite tuff, from base of Tilzapotla ringolite series. Fumice frasments are collapsed and bent around diopside, fayalite, and andesine crystals. Inciplent devitrification has attacked the Elass. Specimen F57-48; plane-polarized 11ght. 
PLATE 8
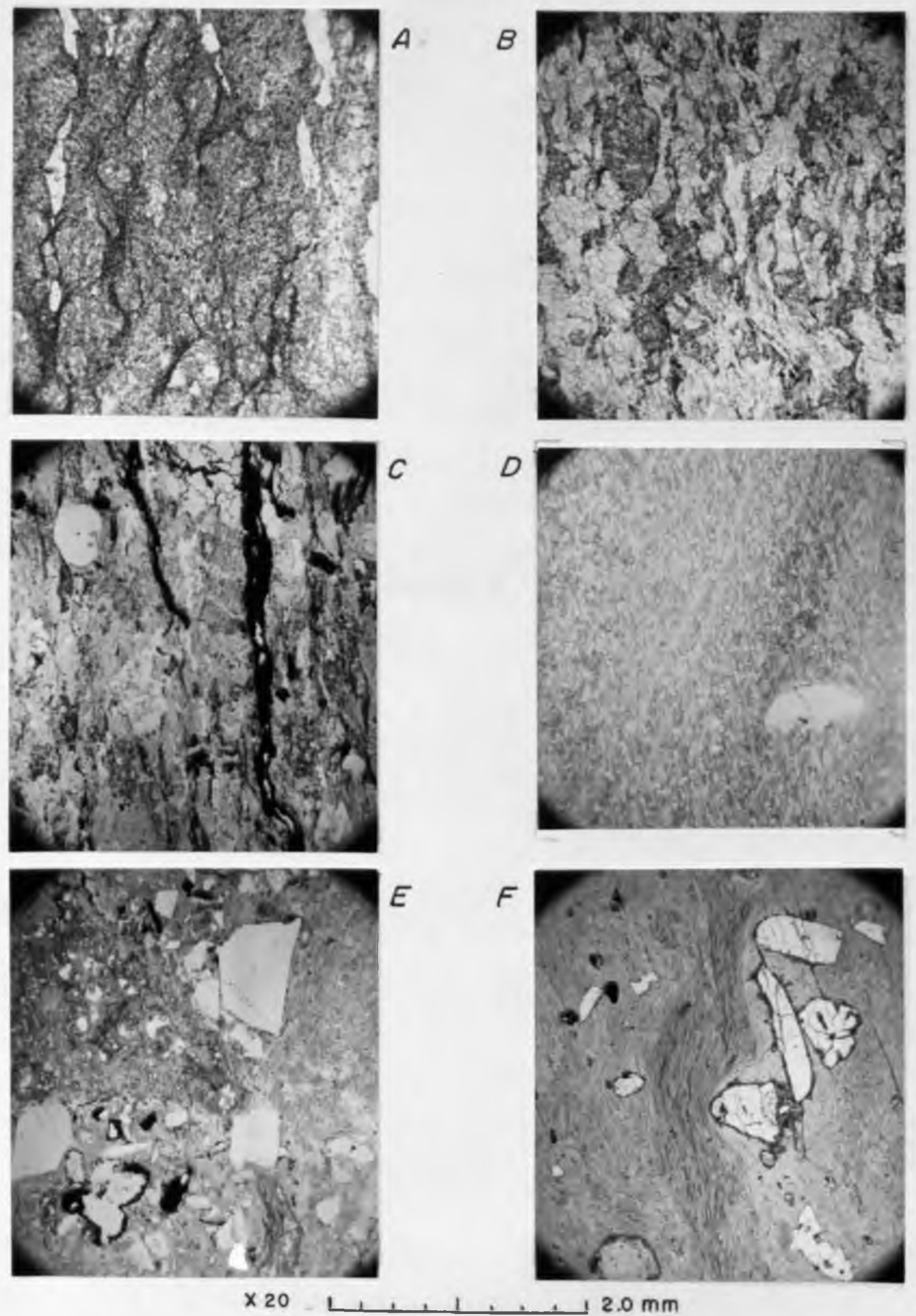
PLATE 9 
PLATE 9

PHOTONICROGRAPHS OF IOH-GRADE SCHIST AND VELDED TUFFS

$\Lambda$, Same rock as in plate $8-D$; embayed igncous quartz crystals appeer in a fine-grained sericite schist from the Taxco schist series. Original rock was apparently a rhyolite tuff. Spec1men F57-58; plane-polarized Iight.

$B$, Fine-grained, banded, almost totally devitrifled, welded crystal-vitric-11thic dacite tuff from the lower part of the Tilzapotla rhyolite series. Black veinlets are superEene hydrous 1ron oxides. Specinen F57-49; plane-polerized light.

C, Same rock as in plate 8-F; fayalite crystal wrapped in welded collapsed pumice fragments. Spec1men 557-48; planepolarized 11ght.

$D$, Same rock as in plate 8-is; devitrifled, welded, finegrained, crystel-vitric-lithic rhyolite tuff from the lower part of the Tilzapotla rhyolite series. Specimen I57-50; plane-polarized 11ght.

E, Same rock as in C, above; collapsed and welded pumice fragments and shards wrap around fayalite crystal. Spec1men F57-48; plane-polarized light.

$F$, Same rock as in $D$, above; specimen $557-50$; plane-polarized I1Eht. 
PLATE 9
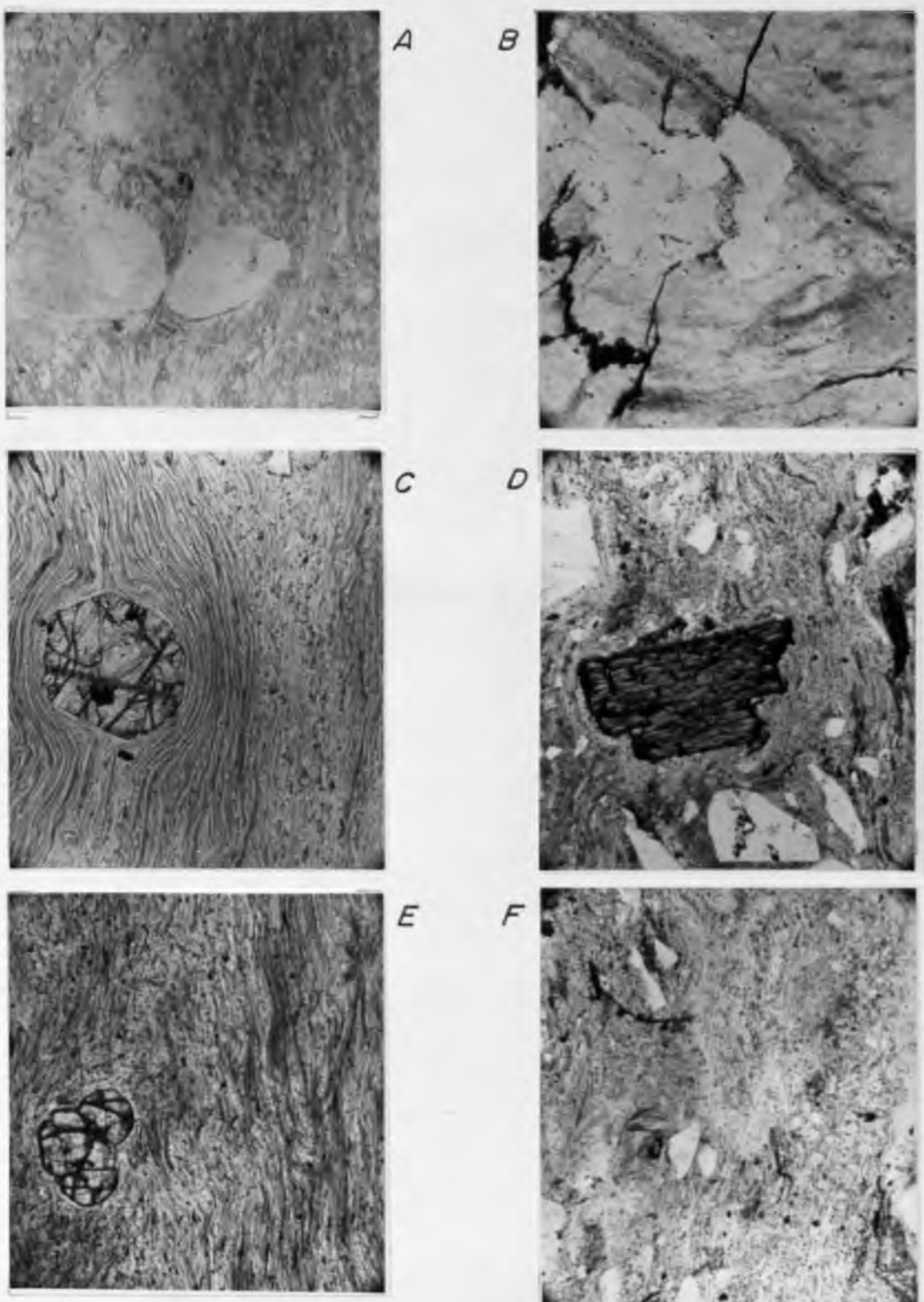

$x>0$
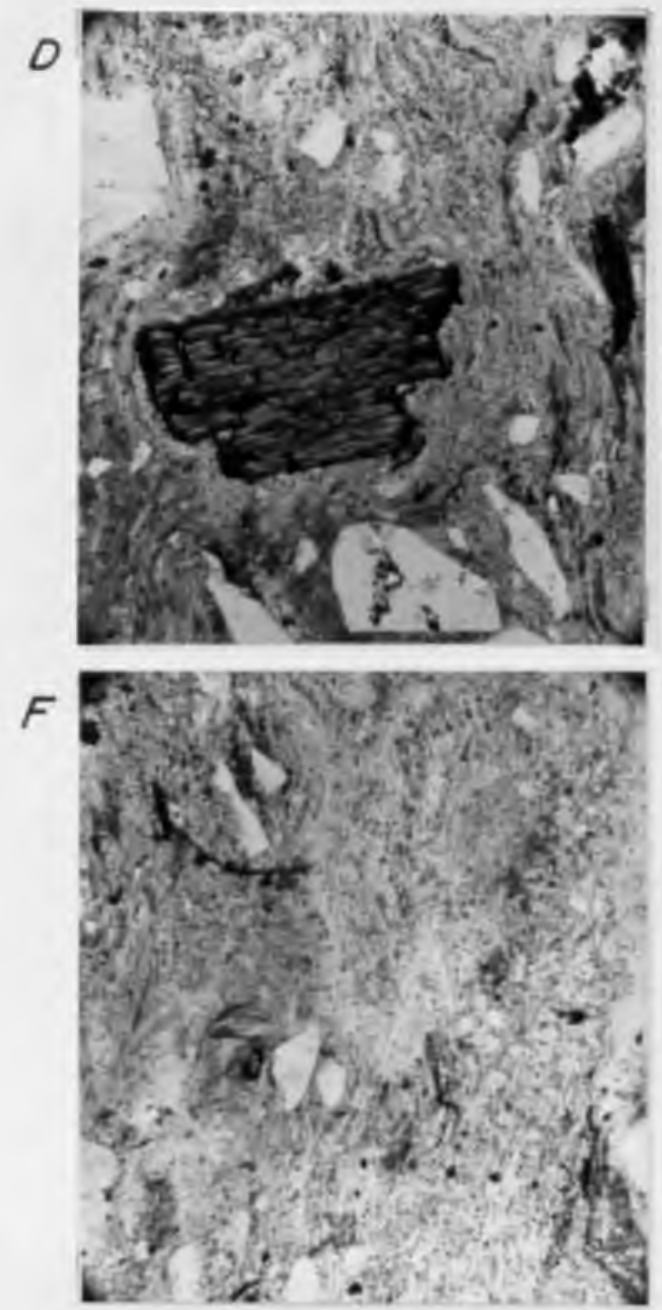


\section{PLATE. 10}




\section{FHOTOGRAPHS SHOHING TEXTURE OF DOLONITIZED LINIETONE FEOM TIE MORELOS FORUMIOH}

A, M11011d-bearing calcarenite, largely dolomitized, from the upper part of the rorelos formation. Elack veinlets consist of calcite f1li1ngs of tectonic fractures. DarkEray roundish Brains are miliolids and calcareous pellets, 2.11 composed of cryptocrystalline calc1te. Light-Gray to whitish matrix consists of fine-grained dolomite. Spec1men F55-39; print of acetate peel of pol1shed surface etched with dilute hydrochloric acid.

B, Fudist1d coquina from the upper part of the liorelos formation, partiy dolomitized: Fine-erained gray matrix consists of calcllutite and is composed of cryptocryetaline calcite. Jore coarsely crystalized material consists of eroded fragments of rudistids which have been replaced by dolomite. Specimen F55-15; print of acetate pee1 of pollahed surface etched ilth dilute hydrochloric ecid.

C, Hearly completely dolomitized limestone from the upper part of the fiorelos formetion. Dark veinlets are calcite filings: of tectonic fractures. Very dark sray dots consist of calcite matrix, the rest belns dolomite. Specimen F-68-54; print of acetate peol of polished surfece etched vith dilute hydrochlorlc acid.

D, Fighly dolomitized I1mestone from the forelos formation. Dark matrix is unreplaced calc1te. Dolonite forms about 80 per cent of the rock. Specimen F-54-54; print of acetate peel of polishod surface etched with dilute hydrochlor1c acid. 
PLATE 10
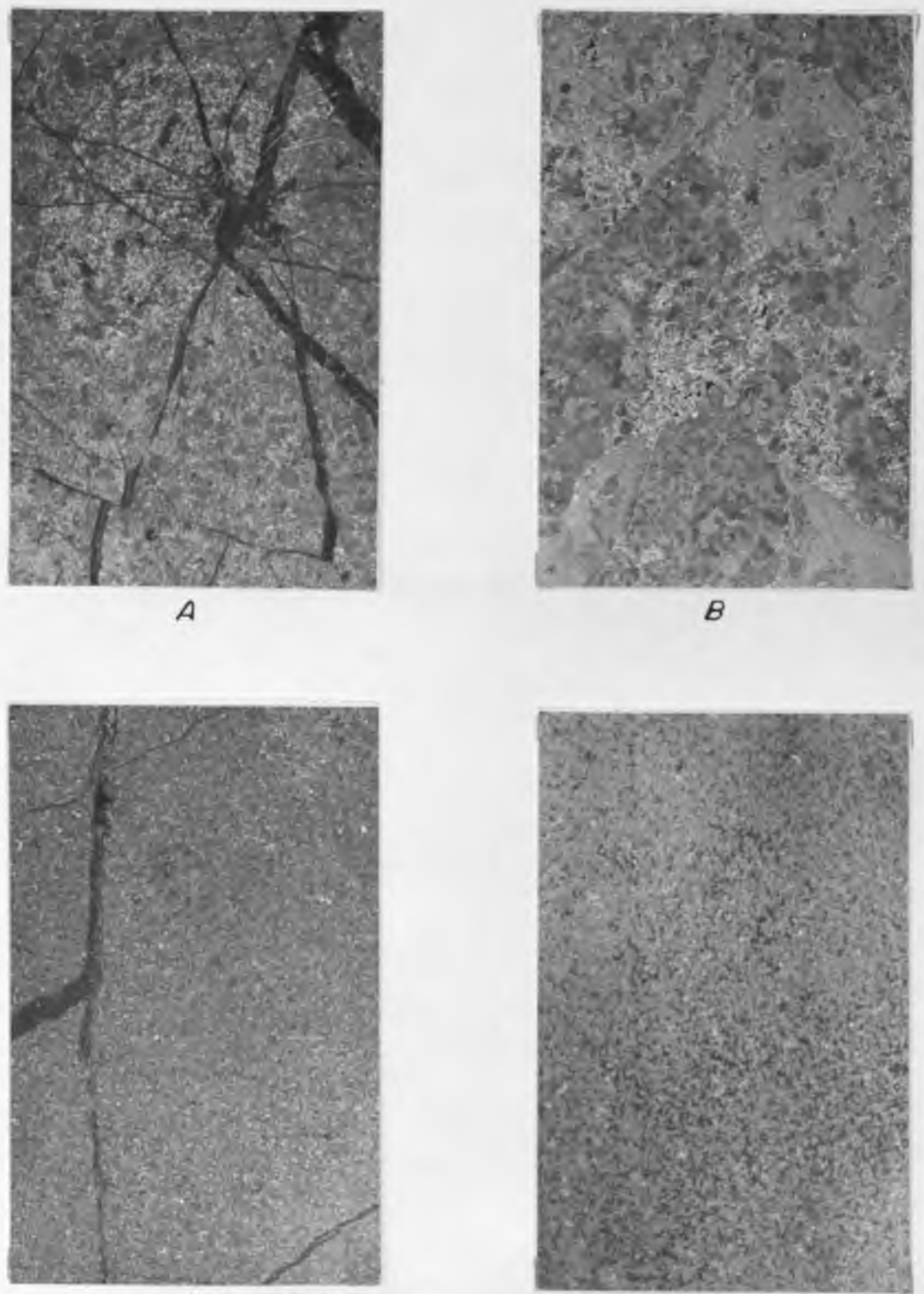

C $\times 5$ 
PLATE 11 
PHOTOGRAPHS SHOWIIG TEXTURE OF IIIESTONE AID DOLOMITE FRON THE HORELOS FORHATION

$A$, Nillolid-bearing calcarenite with sections of partiy siliclfied shells of Toucasia sp. from the upper part of the liorelos formation. The foraminifera may be seen with a hand lens. The thin rudistid shell (Toucasia) is composed of calcite, except where sillca has roplaced 1t irregularIy (structureless black patches); the shell is somewhat abraded. Tectonic fractures are healed by calcite (darkGray velnlets). Iote polnted keel of Toucasia in lower rieht corner. Specimon F-6-54; print of acetate peel of polished surface etched with dilute hydrochloric ac1d.

B, Very fino grained miliolid-bearing calcarenite from the uppemost $10 \mathrm{~m}$. of the Norelos formation. Abundant individuals of liunmoloculina heimi Bonet may be seen with a hand lens, as rell as other foraminifora. Tectonic fractures are healed by calcite. Rock is not dolomitized. Specimen F55-38; print of acetate peeI of polished surfece etched with dilute hydrochloric acid.

C, Irregularly dolomitized Ifmestone from the upper part of the Horelos formation. Black matrix is unreplaced calcite; the rest is doIonitie. Rocls contains about 75 per cent dolomite. Specimon F-38-50; print of acetate peel of pollshed surface etched with dilute hydrochloric acid.

D, Nottled, irregularly dolowitined limestone from the upper part of the Yorelos formation. The dark patches are unreplaced cryptocrystaline calcite, and the light patches are nearly completely replaced by dolomite. The rocir contains some 40 per cent dolomite. Tectonic fractures are healed by calcite (dark-Eray veinlets). Original sediment was a fine-Erained calcarenite contalning auch comminuted blosenic matter. specimen F-37-54; print of acetate peeI of polished surface etched with aliute hydrochloric acid. 
PLATE II
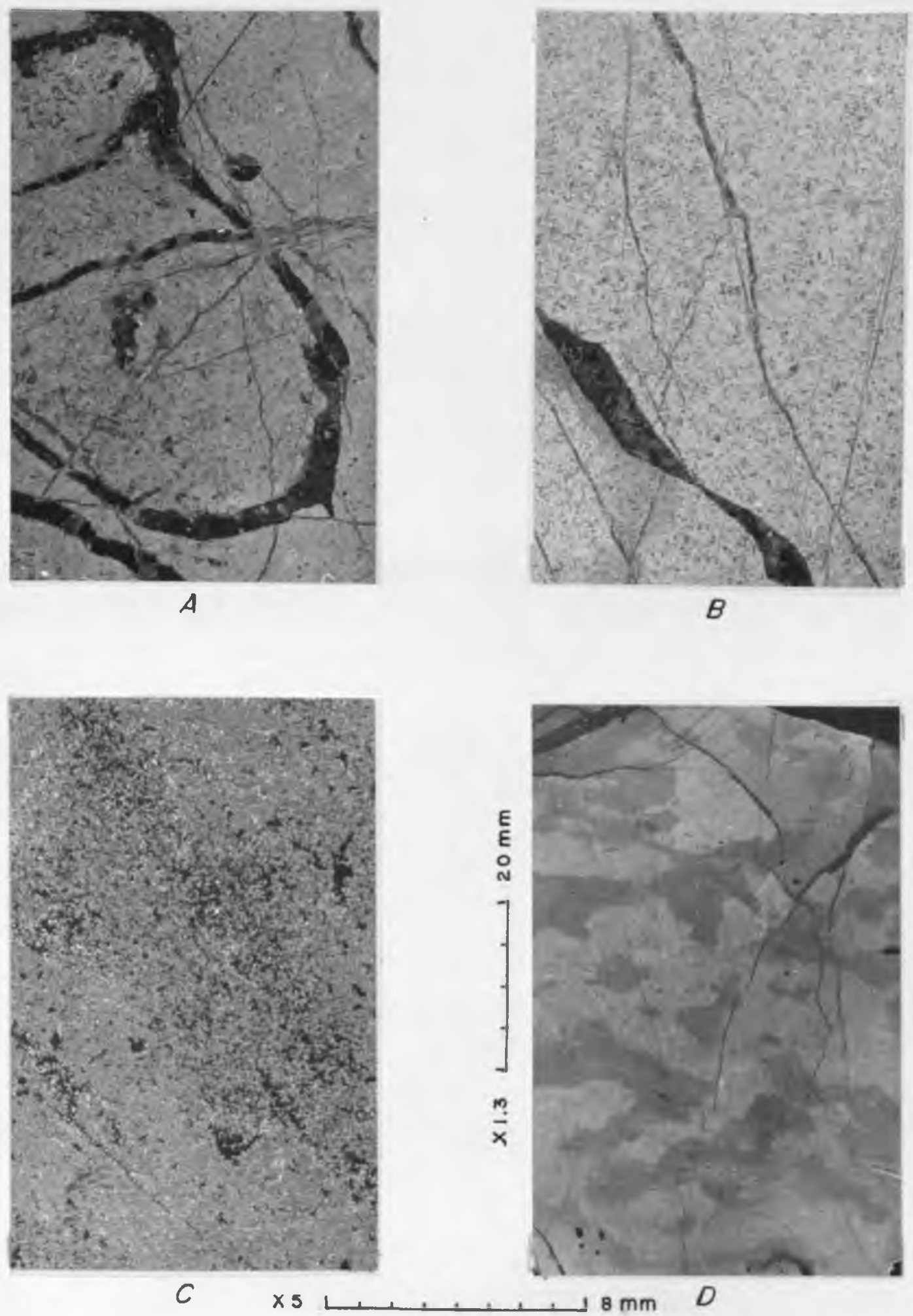


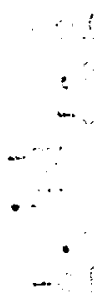

$\because 5$
1

PLATE 12 
PIATE 12

PHOTOGRAPHS SHOHING TEXTURE OF IIUESTONE FROM THE YORELOS FORIMATION

A, Calcarenite from the upper part of the El Abra formation in the quarries along the raliroad east of Cludad Valles, easternmost San Iuls potosf, a well known "reference" locality. This 1.8 equivalent in age and 11thology to the upper part of the Morelos formation, although it 11es $350 \mathrm{~km}$. to the north and 18 not connected by continuous outcrops. Note with a hand lens the ebundant individuals of Nummoloculina heimi Bonet, which characterizes the upper part of both the EI Abra and Morelos formations. Dark matrix is clear calcite. Specimen F-19-52; print of acetate peel of polished surface etched with dilute hydrochloric acld.

B, MIlol1d-bearins calcarenite from the top of the Morelos formation. Hote with a hand lens the abundant individuals of Nummoloculina helmi Bonet and Dicyclina schlumberser1 yunier-Chalmas, which characterize this part of the formation and indicate an early Cenomanian age. Specimen F-7-54; print of acetate peel of polished surface etched with hydrochloric acid.

C, H110lid-bearing calcarenite with partly silicified mudistid fragments from the upper part of the Horelos formation. Note with a hand lens the foraminlfera and the incomplete silicification of the calcareous shell matter, with destruction of shell texture and structure. The s111ca appears lighter in color in this print than the black, clear calcite. Specimen F-5-50; print of acetate peel of polished surface etched with aliute hydrochloric acid.

D, Mil10l1a-bearing calcarenite with a partiy silicified, abraded fragment of Ostrea $\mathrm{cp}$. Note with a hand lens the irregular silicification of the calcareous shell matter and destruction of the shell texture. Dark-gray veinlets are calcite-filled tectonic fractures. Specimen F-25-53; print of acetate peel of pollshed surface etched with dilute hyarochioric acid. 
PLATE 12
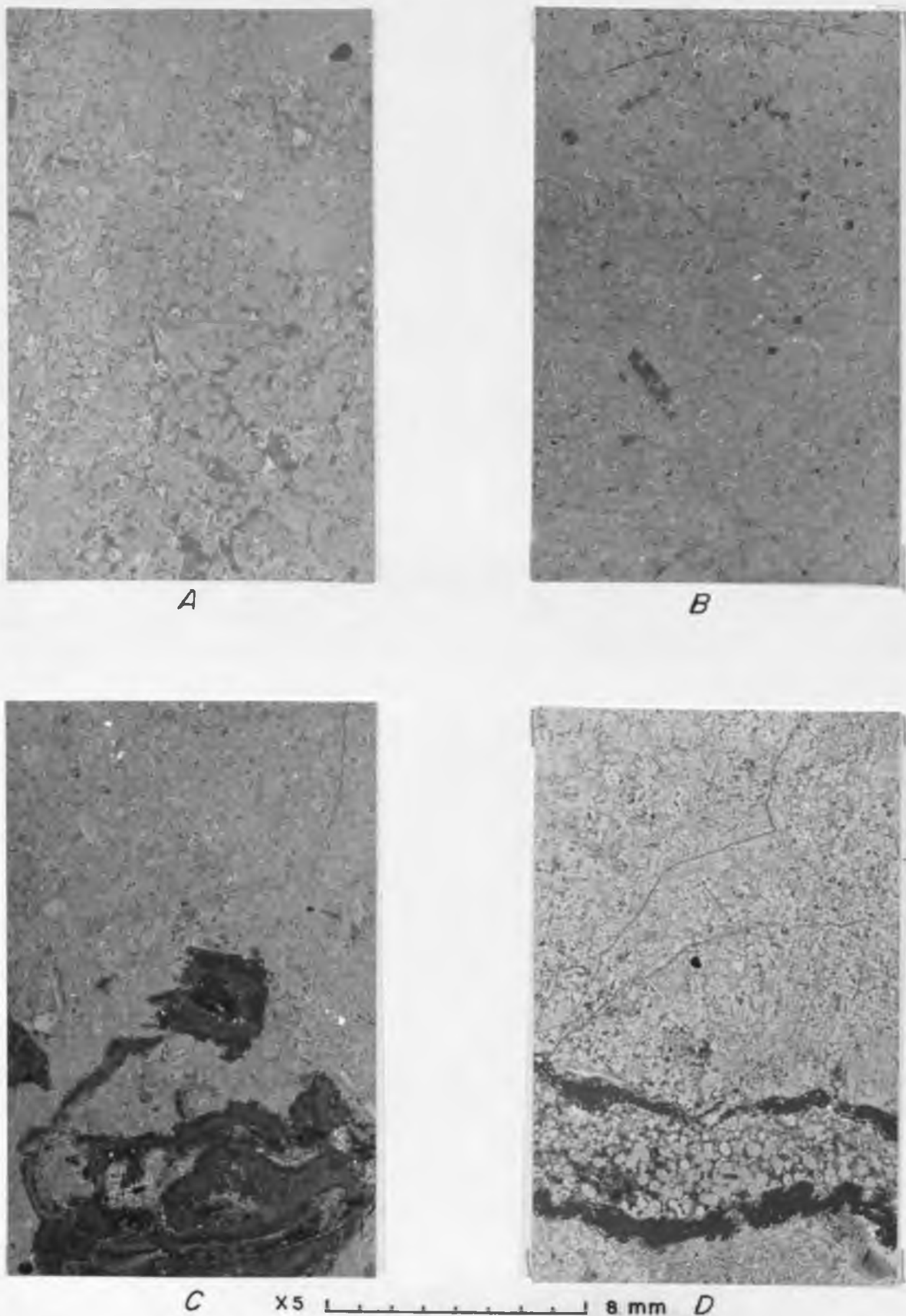
PLATE 13 


\section{PLATE 13}

PHOTOGRAPHS SHOHIHG TEXTURE OF DOLONITIZED IIIMSTONE FRO: THE MORTLOS FORIATION, AND A BASAL CARBOHATE CONGLOERATE FRON THE CUNUTLA FORHATION

$\therefore$, Fartly silicifled and partly dolomitized rudistid frasments in slightly dolomitized celcarenite from well down in tho yorolos formation. Both silica and masnesla replacod selectively the crrbonate of the rudistid shells, rather than tint of the calcaronite matrix. Specimen F55-31; print of acetate peel of polished surface etched with dilute hydrochloric acid.

$B$, Inoroughly dolomitized bed in the Norelos formation, shattored by tectonic movements and re-cemented by clear calcite (blecle), flvine a brecciated "pavemont" appearance to the rocls in outcrop. Specimen $5-51-54$; print of acetate poel of polished surface etched with dilute hydrochloric acia.

C, Very fine grained carbonate conflomerate forming basal beds of the cuautis formation. Carbonate grains are subansular to rounded and consist mainly of limestone and colcite, but some are of dolomite and rare Erains are of chert. Sone pebbles contain foraminifera characteristic of the iforelos formation. Cementing matter is clear calcite (darle matrix). Conglomerete constituents were oroded Irom various beds in the upper part of the liorelos formation. Specimen F-33-54; print of acetate peel of polished surface etched vith dilute hydrochloric acid.

$D$, Same specinen as C, above, but enlarged. Note with a hand leng the foraninffera in the largest pebble (letter " $y$ "). Specinen F-33-54; print of acetate peel of pol1shed surface etched vith dilute hydrochloric acid. 
PLATE 13
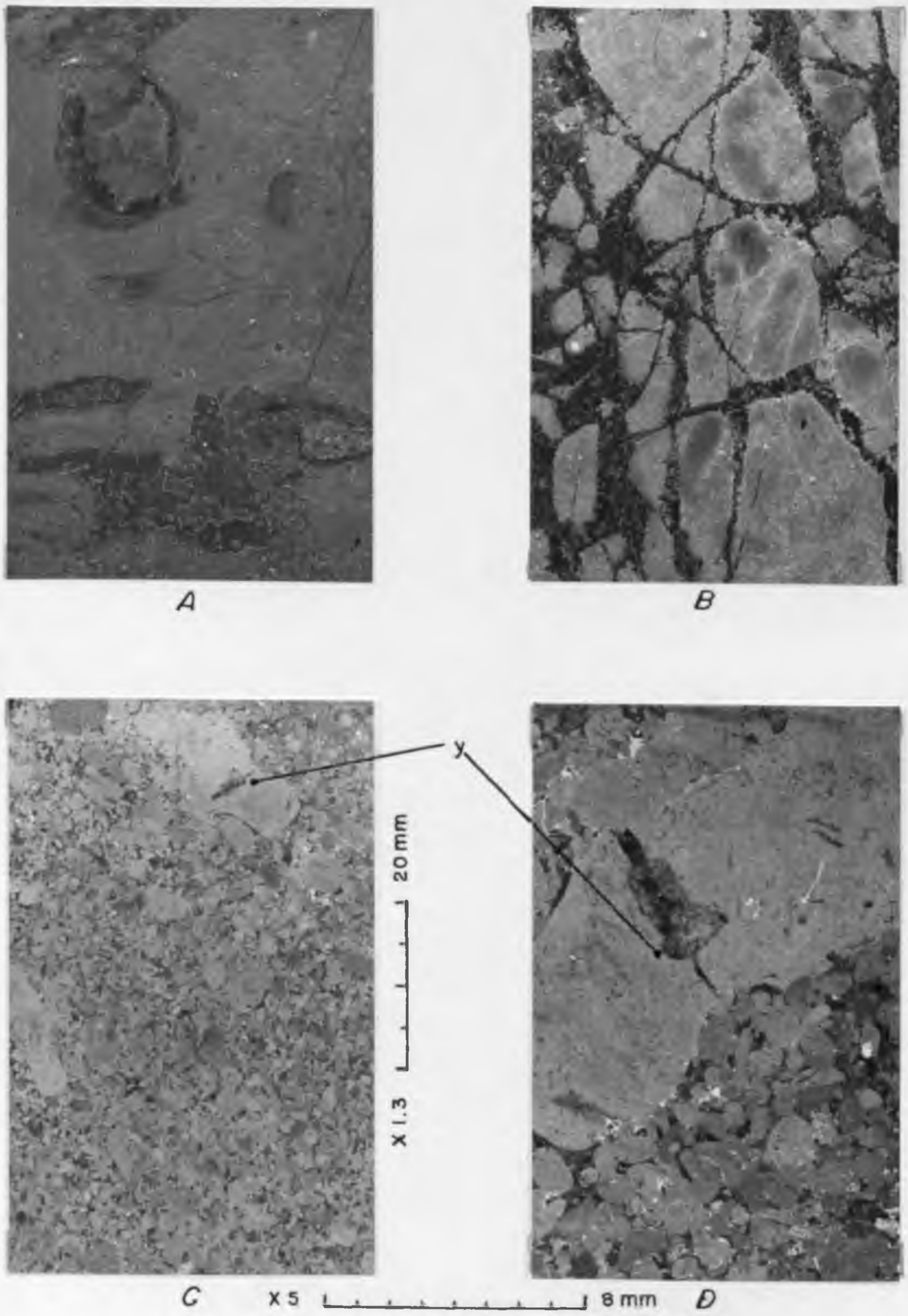
PLATE: 14 
PHOTOGRAPHS SHOWIMG TEXTURE OF RASA CALCARENITE AND RUDISTID LINESTOIE FRO: THE CUAUTLA FORMTION

A, Basel carbonate clastic bed Irom the Cuautla formation, composed largely of dolomite grains eroded from the NoreIOS fomation. Grains are subangular to subrounded and consist of finely crystallized, turbid dolomite of various shades of eray to brow. Cement is clear calcite (black matrix). Specimen $555-4$; print of acetate peel of poliahed surface etched with dilute hydrochloric acid.

$B$, Same surface as $\Lambda$, above, but stronsly etched with hydrochloric acid to emphasize calcite matrix (black). Grains " $y$ " and " $z$ " are common to both $A$ and $B$. Note raced border of-many grains, owing to new crystalilation of dolomite around clastic Grains. Specimen F55-4; print of acetate peel of pollshed surface stronsly etched with dilute hydrochlor1c ac1d.

C, Crushed specimen of Hippurites resectus var. mexicanus in celcilutite from the upper part of the Cuautla formation. The three pronss extendins toward the central chamber are characteristic of Hippurites in transverse section near the top of the larger valve. The matrix is composed of carbonate Erains and frajuents of blosenic matter. Specimen 1s not silicified. Comparo with photogreph in plate 17-B. Specimen F-23-54; print of acetate peel of polished surface etched with dilute hydrochloric acid.

$D$, Section of shell of Toucasia $\mathrm{sp}$. In calcarente from the lower part of the Cuautia formation. Note with a hand lens the texture of the unsilicifled shell. The matrix 1s composed of blogonic grains and unidentiflable microfauns. IIIlolids characteristic of the Horelos formation are totaliy lacking in the Cuautla formation, excopt in the lowermost beds as clastic grains eroded from the lorelos formation. Dolomite is rare to absent in the Cuautla formation. Specimen F.63-50; print of acetate peel of polished surface etched with dilute hydrochloric acid. 
PLATE 14
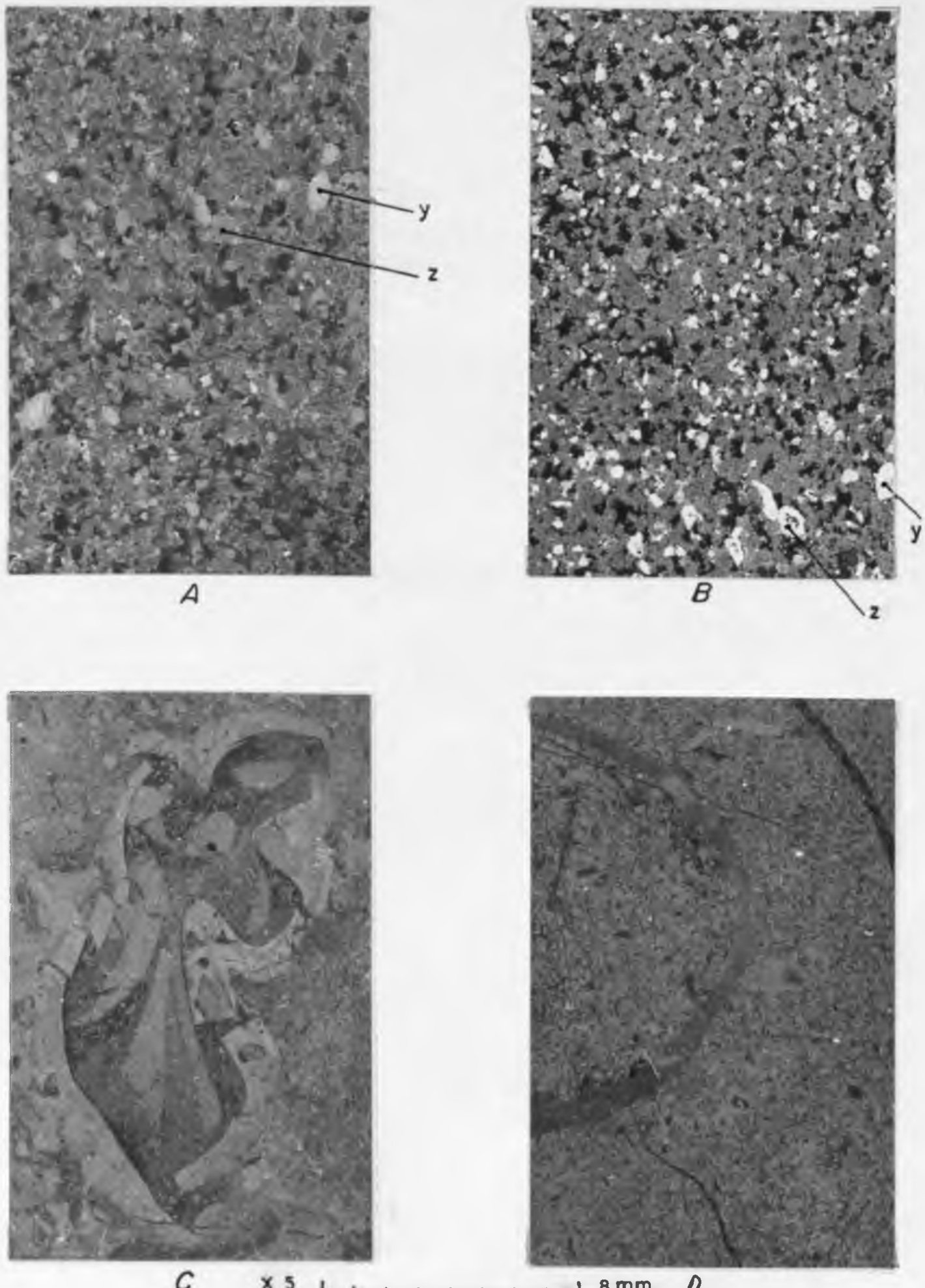

$8 \mathrm{~mm} \mathrm{D}$ 


\section{PLATE 15}

$$
322
$$




\section{PLATE 15}

FHOTCGRAPHS SHOWIHE TEXTURE OF SEDIIENITRY ROCKS FROL THE CUAUTLA AID VEXCALA FORUATIONS AND THE BAISAS CLASTIC GROUP

$\Lambda$, Basal areillaceous calcarenite from the lexcala formation. Wote with a hand lens the sheared zone crossing the photoGraph diasonally. inis and later tectonic cross fractures are healed by calcite. Rocle contains rare specimens of P1thonella oval1s(?) and Calc1sphaerula(?) sp.; flsh scalos are also present. specinen $\mathrm{F}^{-28-54 ;}$ print of acetate peel of polished surface etched with dilute hydrochloric ac1d.

$B$; Partly silicified coral colony of the genus Columastrae$a(?)$ from the upper part of the Cuautla formation. liatrix Is celcilutite or calcarente, with some blogenic fragments. llote tectonlc frectures cemented by calcite (black velnlets). Specinon F-83-50; print of acetate peel of polished surface etched with dilute hydrochloric acid.

C, Subrounded to anfular fanzlomerate from the Balsas clast1c sroup, composed of limestone, dolomite, and chert eroded from the Cretaceous formations. irote Great variety of carbonate crains. Natrix is mixture of clay, calcite, and iron oxidea. Specimen F-36-54; print of ecetate peel

etched with dilute hydrochlorlc acld.

$D$, Same surface as $C$, above, but onlarged. llote that " $y$ " is the same Erain in both $C$ and $D$. Thls fanglomerate 18.posttectonic, as indicated by the calcite-healed tectonlc fractures in some of the Erains. The rock is firmly cemented by calc1to. Specinen F-36-54; print of acetate peel etched with dilute hydrochloric acid. 


\section{PLATE 15}
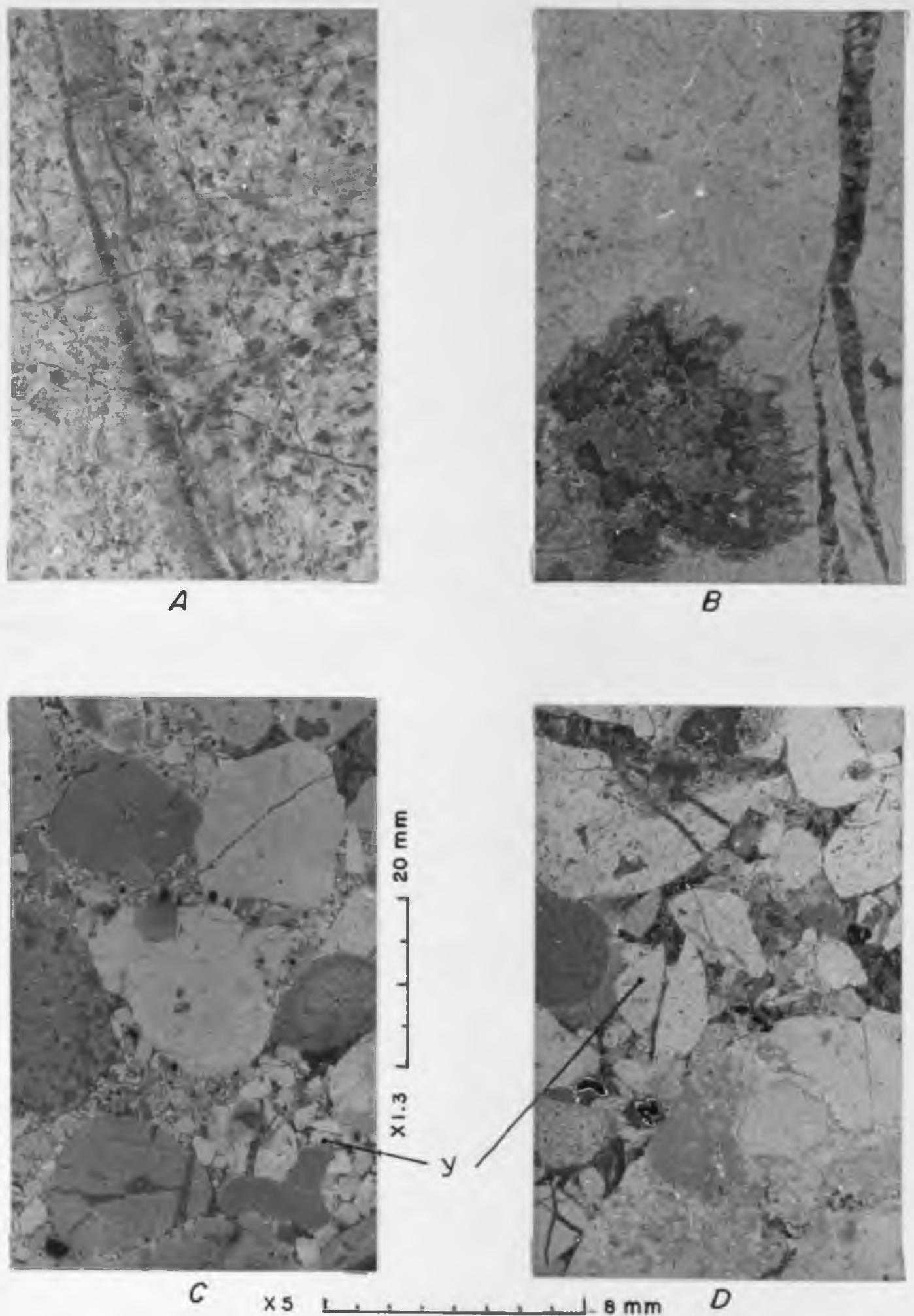
PLATE 16 


\section{PHOTOGRAPHS OF RUDISTIDS IN VEATHERED OUTCROPS OF} THE CUAULA FORISTION

A, Transverse and longltudinal sections of individuals of $\mathrm{Du}$ rania cornu-pestoris in weathered outcrop of the upper part of the Cuautia formation. Note the neariy medial lonsitudinal section of the individual in the upper right comer, ahowing the thick waII and IIving chamber of the larger valve, and the nearly flat operculum-Iiko smaller valve in place. Shell texture and s.tructure are not visible because of the great photographic enlargement. A transverse seotion near the top of the larger valve of another individual appears near the center of the photograph, showling the ahanacteristic cross-section of the Ilvine chamber. Shells are in $a$ blostrome of this species, together with other rudistIds and some sastropods.

$B$, Varlously oriented sections through individuals of sever al species of rudistids in veathered outcrop of the upper part of the Cuautia formation. The massive, deris-gray unsilicified rudistids are individuals of Durania cormu-pastorls. iost of the o1licified elongated Individuels, Ike those in the upper and lower right comers, are of the epec1es Hippurites resectus ver. mexicanus. Other elonsated siliciried shelis represent species of the genus Radiol1tes. Wear the bottom and in the lower left comer are sections through Toucasia sp. lost of these shells were abraded by wave action before deposition but must be very near to the place where the animals actualiy IIved. 

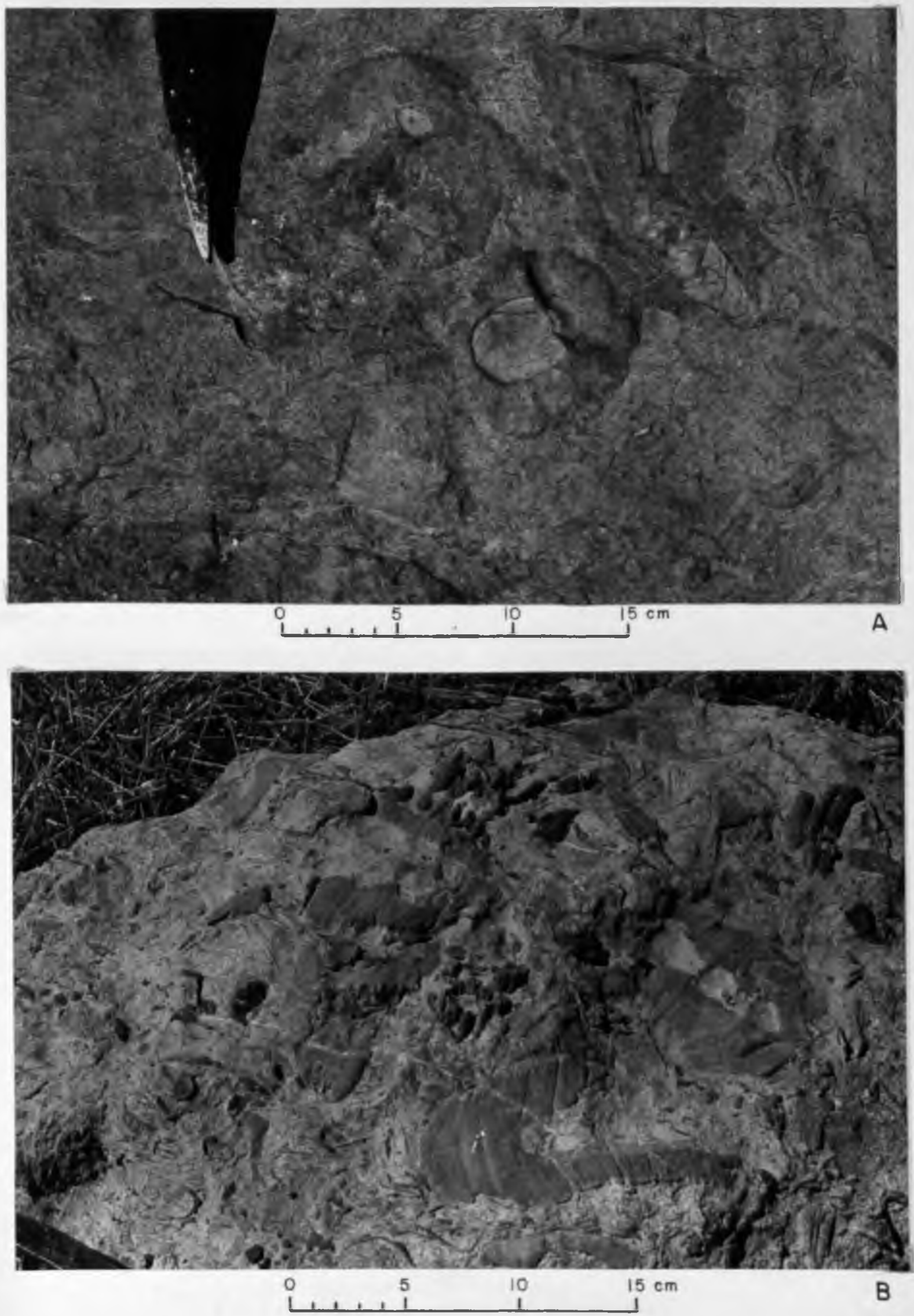
PLATE 17

324 


\section{IIATE 17}

PHOTOERAPES OF RUDISTIDS II VEATHERED OUTCROES OF THE CUAUTLS FORLINTION

A. Blostrome of silicifled individuris of loucasie sp. These are disarticulated and consist almost wholly of the lerger. left valve. The smeller, inconeplcuous, nearly flat, operculum-like right valve is not distingulshable in the photoEraph. Tils particulsr species forms biostromes in the lower part of the Cuautla formation and is present tozother vith Ilppuriteg resectus var. mexicanus in some beds.

$B$, Trensverse section noar the top of a colony of individuals of hilppurites resectus var. mexicanus, as $1 \mathrm{t}$ appears in a veathered outcrop in the middie part of the cuautia formation. The shells are nearly completely silicified, and nearby individuals retain in place the nearly flet, operculum-Iike right valve. This species occurs in biostromes of colonies and separate individuals, and is assoclated with lierinoe sp., nctseonelia sp., Durania comu-pastoris, two or three specios of praijolites, and periaps two other specles of Ilppurites. 

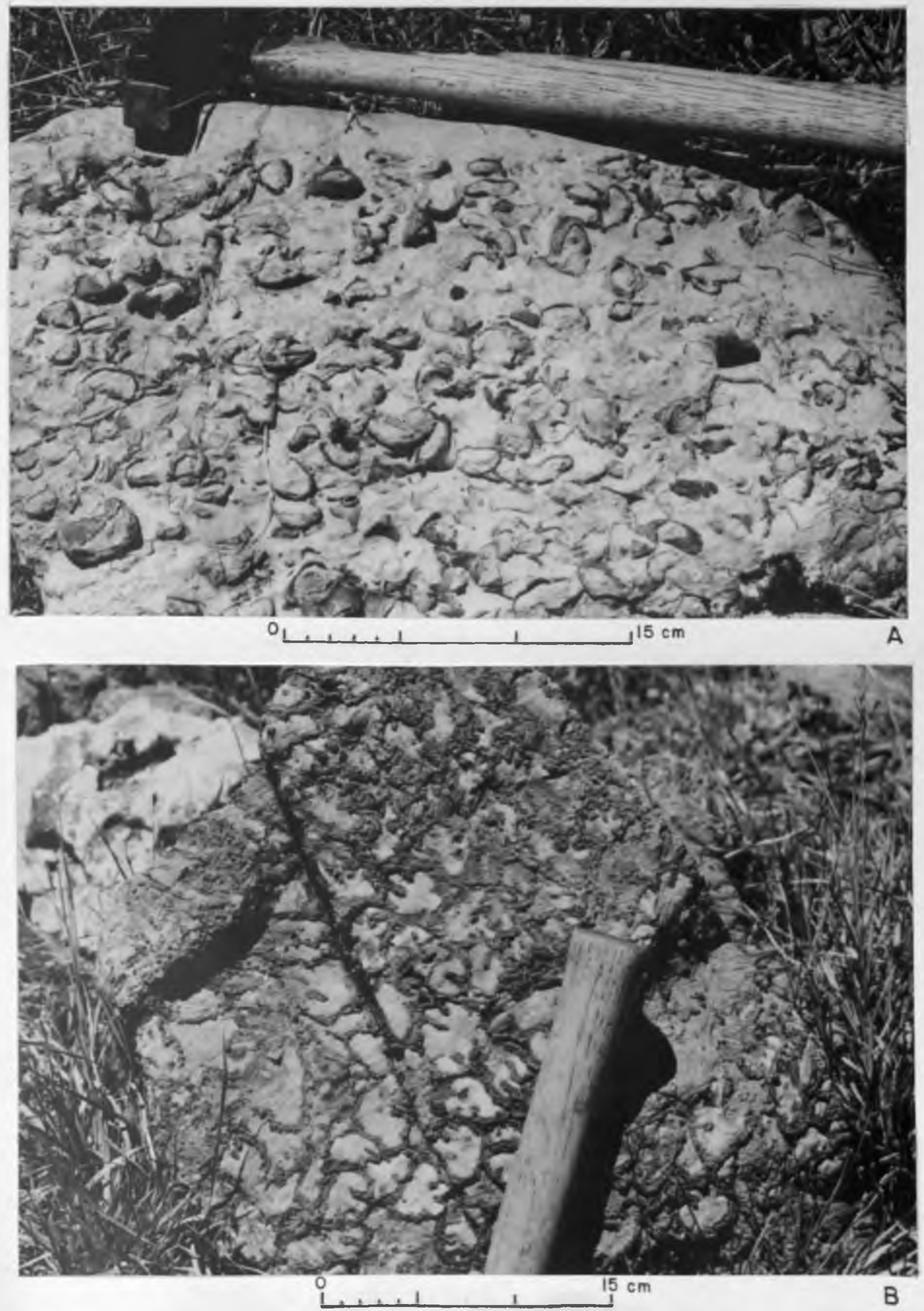
PLATE 18 
FHOTOHICROGRAPHS OF SEDIUTERTRY ROCKS FRON THE MEXCNIA FORUATION, TEE B.ISAS CLASTIC GROUP, AND THE CUEPHAVACA FORIATION

A, Fine-grained subsraywacke from well up in the llexcala form mation. The rock is composed of Eralins of Iimestone, calcite, quertz, chert, feldspar, and ferromagneslan minerals altered to chlorite and Iron ores. Cementing matter is mainly calcite. Specimen F55-18; plane-polar1zed lisht.

B; Fresh-water Iinestone or trevertine from the Cuemavaca fornation; composed of irregular, eonerally curved fragments of turbid, cryptocrystaline calcite stained with hyarous iron oxides, in a matrix of clear, coarser-grained calc1te. The rock is vugsy and has some 20 per cent pore space. It vas probebly formed by lime accumulation on plant stems and roots, which were subsequently eliminnted by oxidation. Specinen F-32-50; plane-polarized light.

c, Flne-grained suberaywacke from near the base of the Hexcala formation; detrital dolomite and I1mestone grains malre up the Ereater part of the rock, quartz formins only about 15 per cent. Feldspar and mica crystals are rare, and chlorite replaces the relatively lew mafic constituents. Specimen F-21-50; plane-polar1zed 11ght.

$D$, lion-marlne Eypoum Interbediod with clastic beds of the Cuemavaca formation. Fellet-like cleer areas are coarsely crystallizea pure sypoun; surroundins inaterial 1s more finely crystallized and contains calcite dust and probebly some clay. Calcite malies up about 15 per cent of the rock. Precipitation occurred in a lake probably no more than a fer ki. lometers in lensth. Specimen F-45-54; plane-polarized light.

I, Carbonaceous siltstone from the lover part of the Kexcala formintion. The rocl consists dominantiy of quartz and contains less Iinestone, feldepar, and altered mafic constituents, with carbonaceous Erains (black graphite(?)) in mude layers. It is finely cross-bedded. Dymanic metamorphism has recrystalized some constituents and developed a I1ttle chlorite and serlcite. Specimen F55-10; plane-polarized 1ight.

F, Globular-like Erains of opaline silica in non-marine gypsun Interbedded with clastlc beds of the Balsas clastic Group. Th1s appears to be a dense chert nodule in hand specimen, but it actually has a matrix of Ejpsum. Spocimen F55-40; plane-polarized I1ght. 

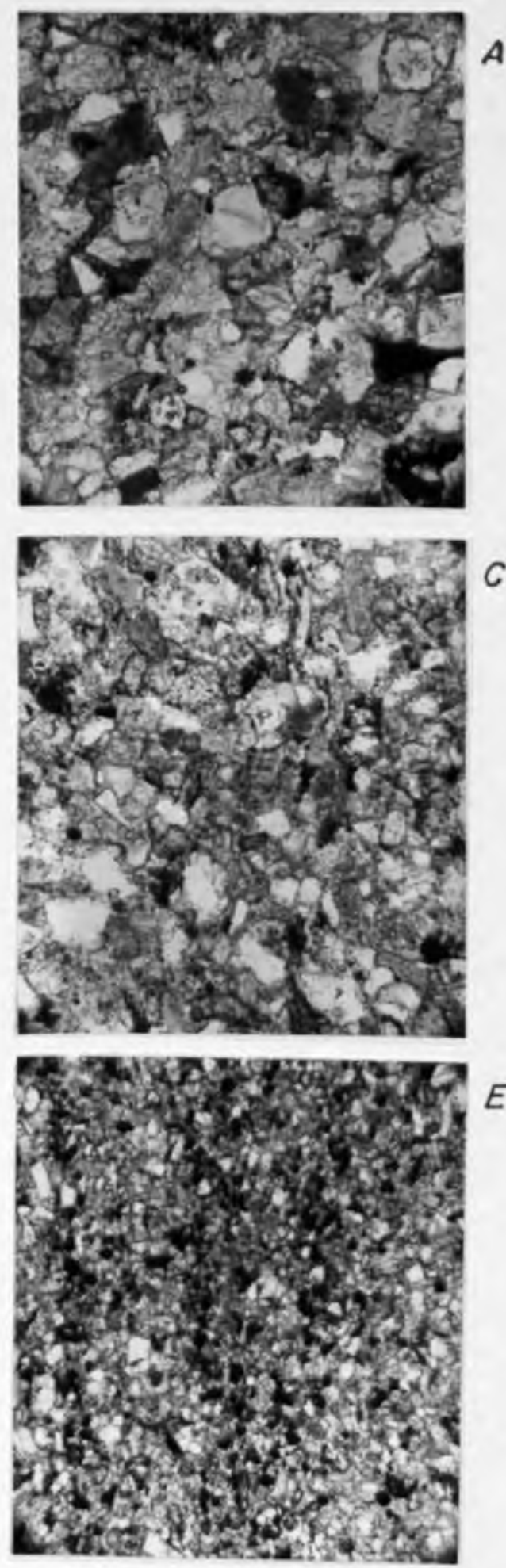

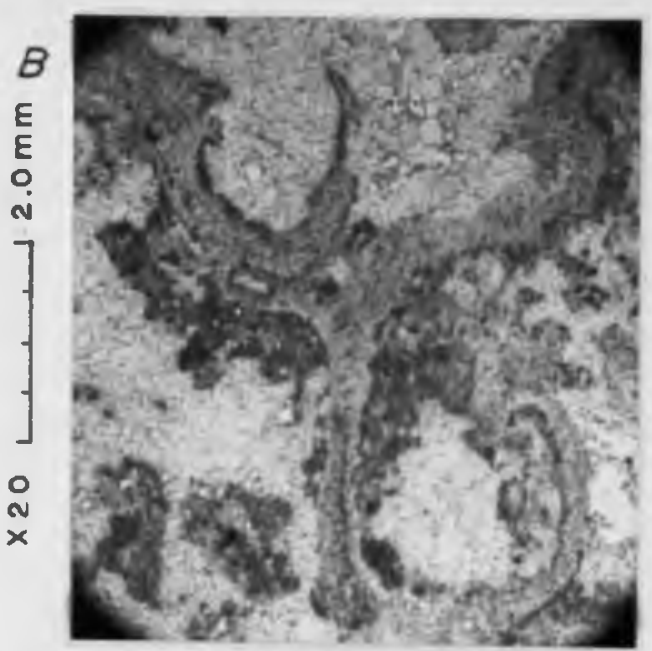

\section{C}
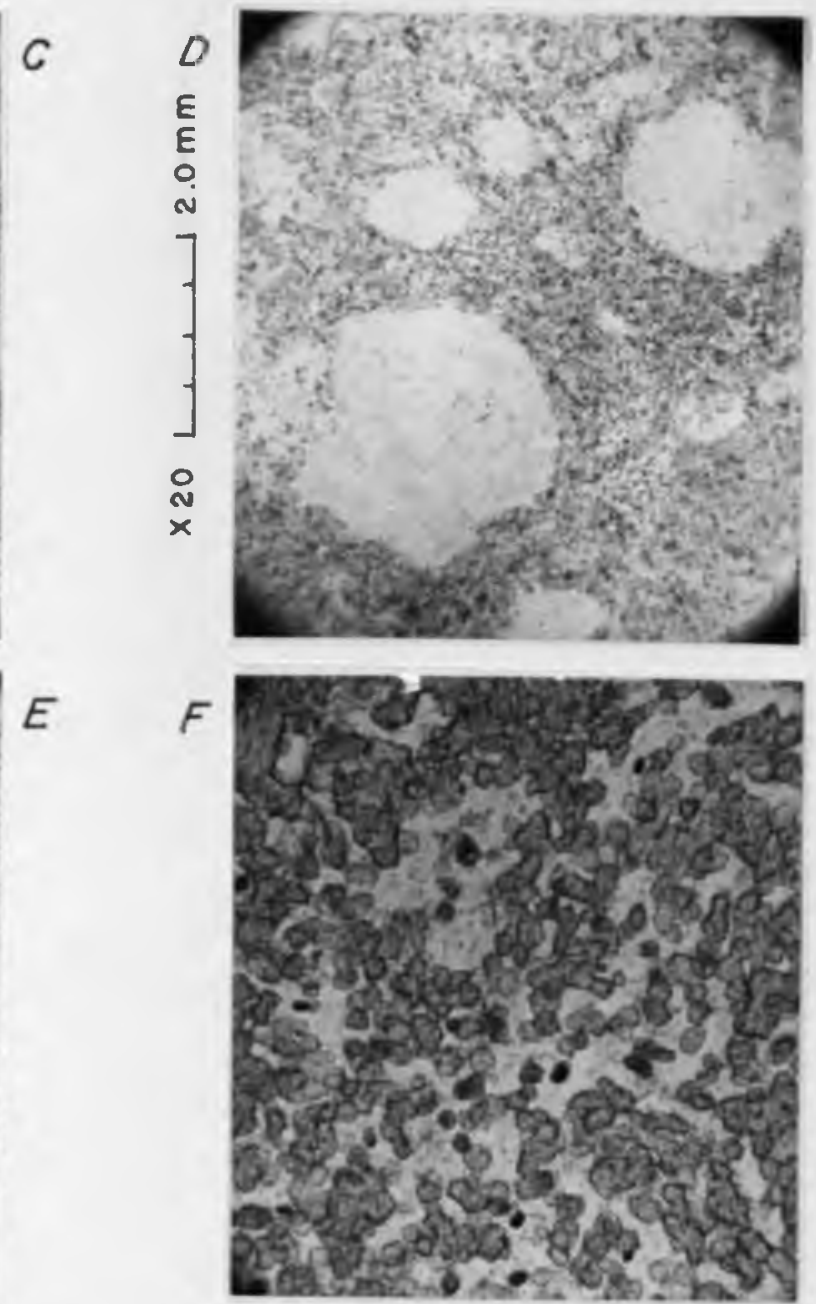
PLATE is 
PHOIONICROGRSDHS OF AHDESITE FIOH ROCKS AHD REYOIITE TUFF

1-II, Examples of andesite flow rocks taken from blocks that male un the Tepoztion formation. lost of these andesites contain both ampinibolo and pyroxene. In some the ferromagnealan minerals have been partly chloritized, and in others the alteration has produced much iron ore. The feldspars are genere.ly andesine, but some phenocrysts have labredor ite cores and more sodic borders. Thin sections of eight other blocks fror this formation vere also all of andesite. Specinens $=55-43 \mathrm{~A}$, F55-43G, F55-43B, F55-43J, and F55-43D, respectively; plane-polarized light.

F, Crystal-11thic ringolite tuff with some devitrifled Elass shares, from the upper part of the Balsas clastic Eroup. liote rrayed and bent blotite crystals. This tuff differs fror tile velded tuffs in plate $8-E$ and plate $9-D$ and $-F$, in lacling collapsed and bent shards and in contalnins bent blotite crystals. It was probably alr deposited, althoush It may hsve been re-worled by reter. Specimen F-35-54; plene-polorized I1ght. 
PLATE I9
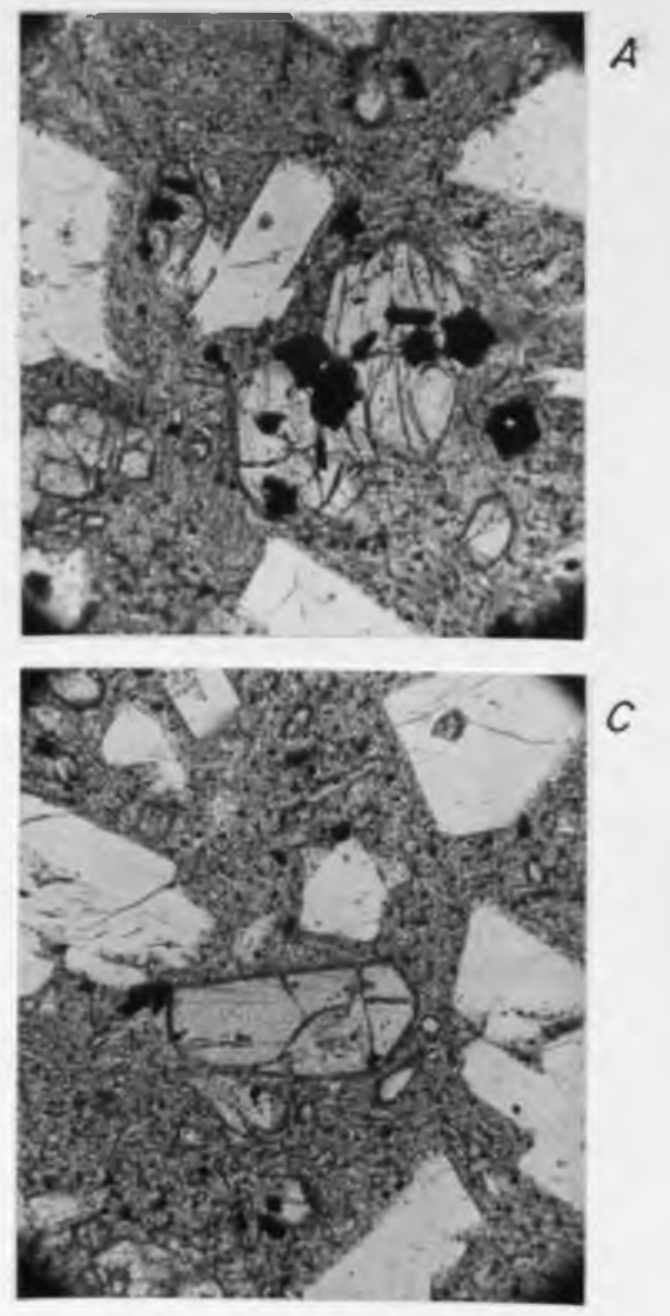

c

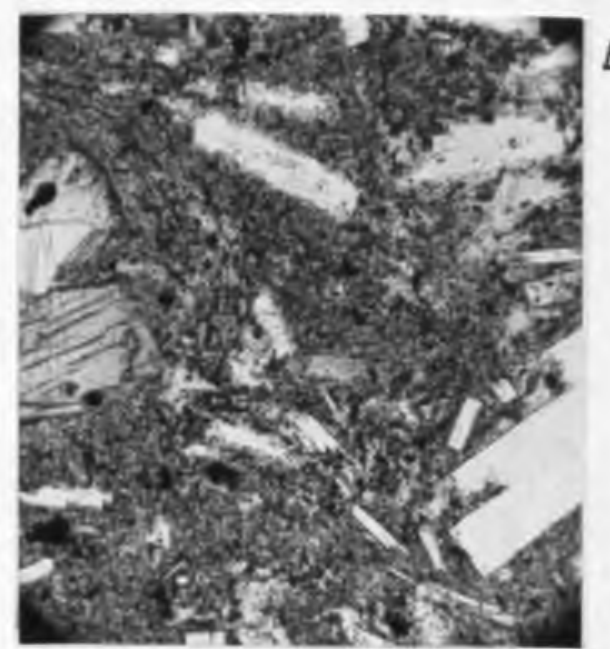

E

$B$

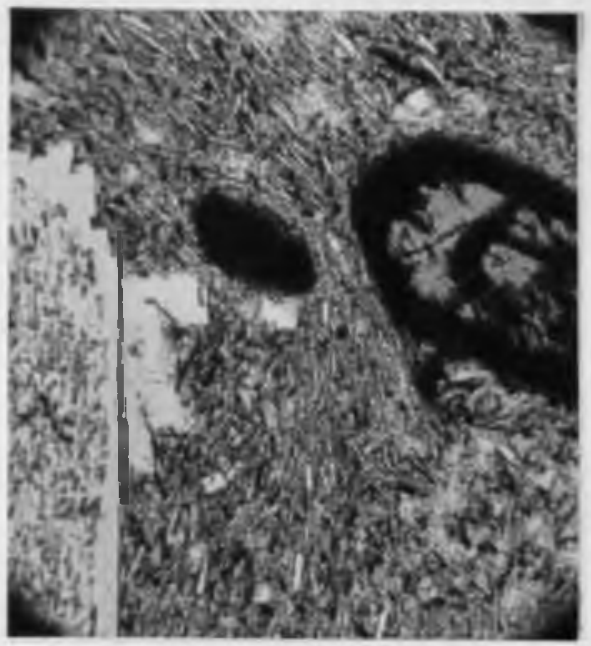

D
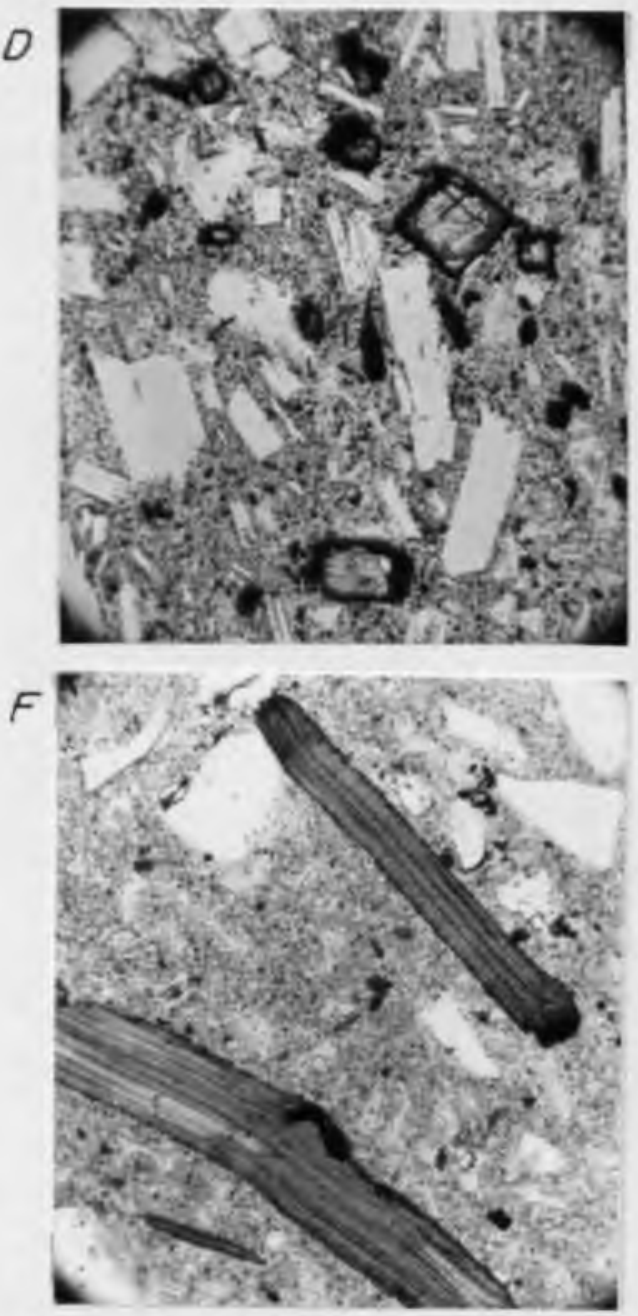
PLATE 20 


\section{PHO'POIICROGRAPHS OF INTRUSIVE DIABASE AHD BASALT FLOW ROCES}

A, Altered diabase from smell stock penetrating the lexcala formation. Hote completely altered pyroxene crystals, composed mainly of iron ores and chlorite. Matrix consists of labredorite microlites and augite grains. Chiorite pervades the rock, probably as a late deuteric product. Some calcite occurs in altered reldspar phenocrysts. Specimen 555-26; plane-polarized light.

$B$, Bltered diabase from small stock penetrating the Balsas clastic Eroup. Similar to $\dot{A}$, above, but pyroxene phenocrysts are smaller and less abundant. Rock is permeated by chlorite; natrix ausite grains remain unaltered. Specimen F55-35; plane-polarized 116ht.

C, Dlabase dise cutting the lorelos formation. Texture is porphyritic and pilotaxitic. Pock containg altered olivine phenocrysts composed mainly of nontronite(?) and calcite. infic matrix constituents consist of hypersthene and ausite, sowe of vhich are altered to nontronite(?). plagloclase mlcrolites are bytomste. Specimen F-21-54; planepolarized light.

$D$, Basalt flov rock Interbedded with clastlc beds of the Balsas clastic group. Rock has porphyritic and ophitic texture. Yafic phenocrysts vere probably ollvine but are now reddish-brom lddingsite(?). iaflc matrix mineral is augite. Chlorito replaces much maf1c material and pervades rock, even in iractures in feldspars. Feldspar microlites are labradortte. Specimen F55-21; plane-polarized 11sht.

E, Fine-Erained ollvine basalt from the Cerro de la Corona volcanlc neck, which cuts the Cretaceous rocks. Rock has porphyritic and pllotaxitic texture. Fhenocrysts ore hypersthene and olivine, the latter completely altered to nontronlte(?), whlch also pervades the rock and replaces the mafic matrix constituents. Feldspar microlites are labrador1te. Epeclmen F-7-50; plane-pälarized I1Eht.

$\vec{F}$, Basalt flow rock from the lower part of the Balsas clastic sroup. Fock has porphyritic and pllotaxitic texture. Fhenocrysts are augite; dark-brow hormblende xenocrysts (?) are present, as shom in the lower right corner of the photograph, where the hornblende has been almost entirely plucked out, leaving only shreds along the s1des. These yenocrysts inve reaction rims of clusters of tinj ausite crystals. Felaspar microlites are labradorite. Chlorite permeates the rock. Specimen F55-22; plane-polar1zed 11ght. 
PLATE 20

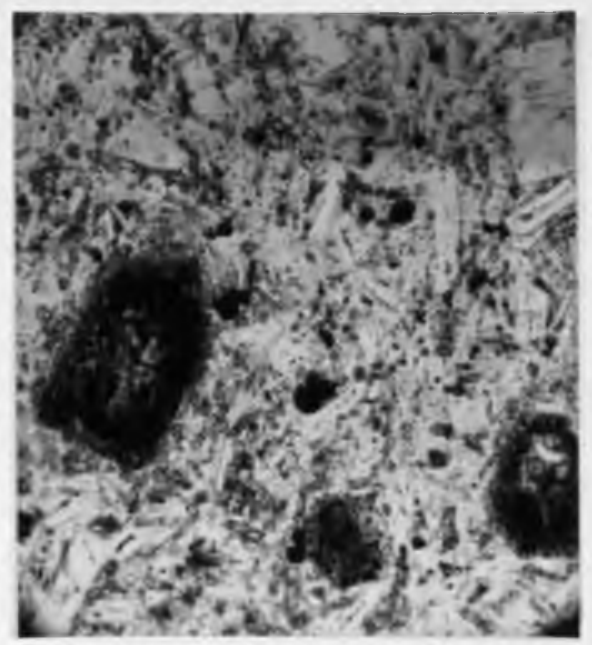

A

B
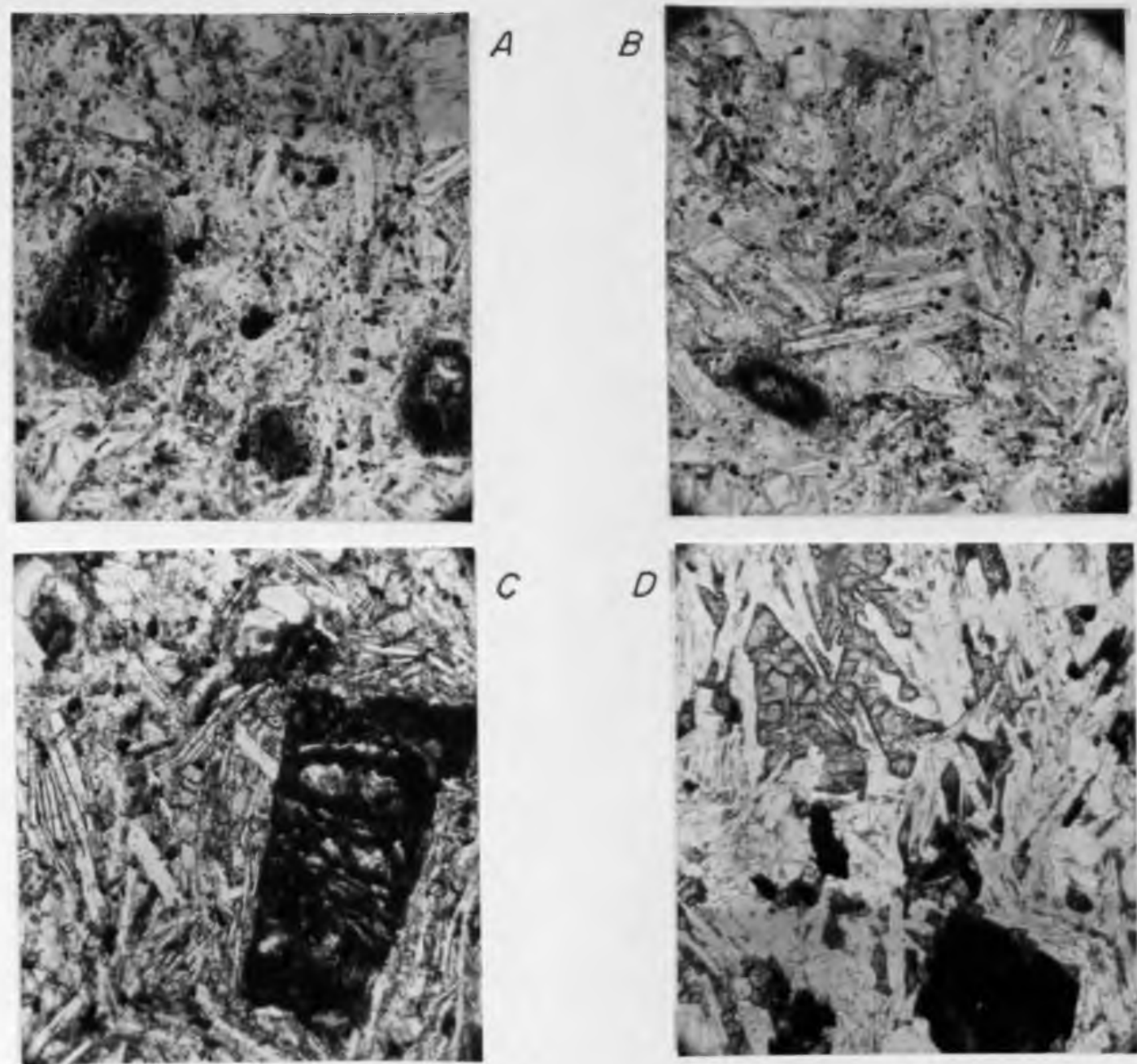

c

of
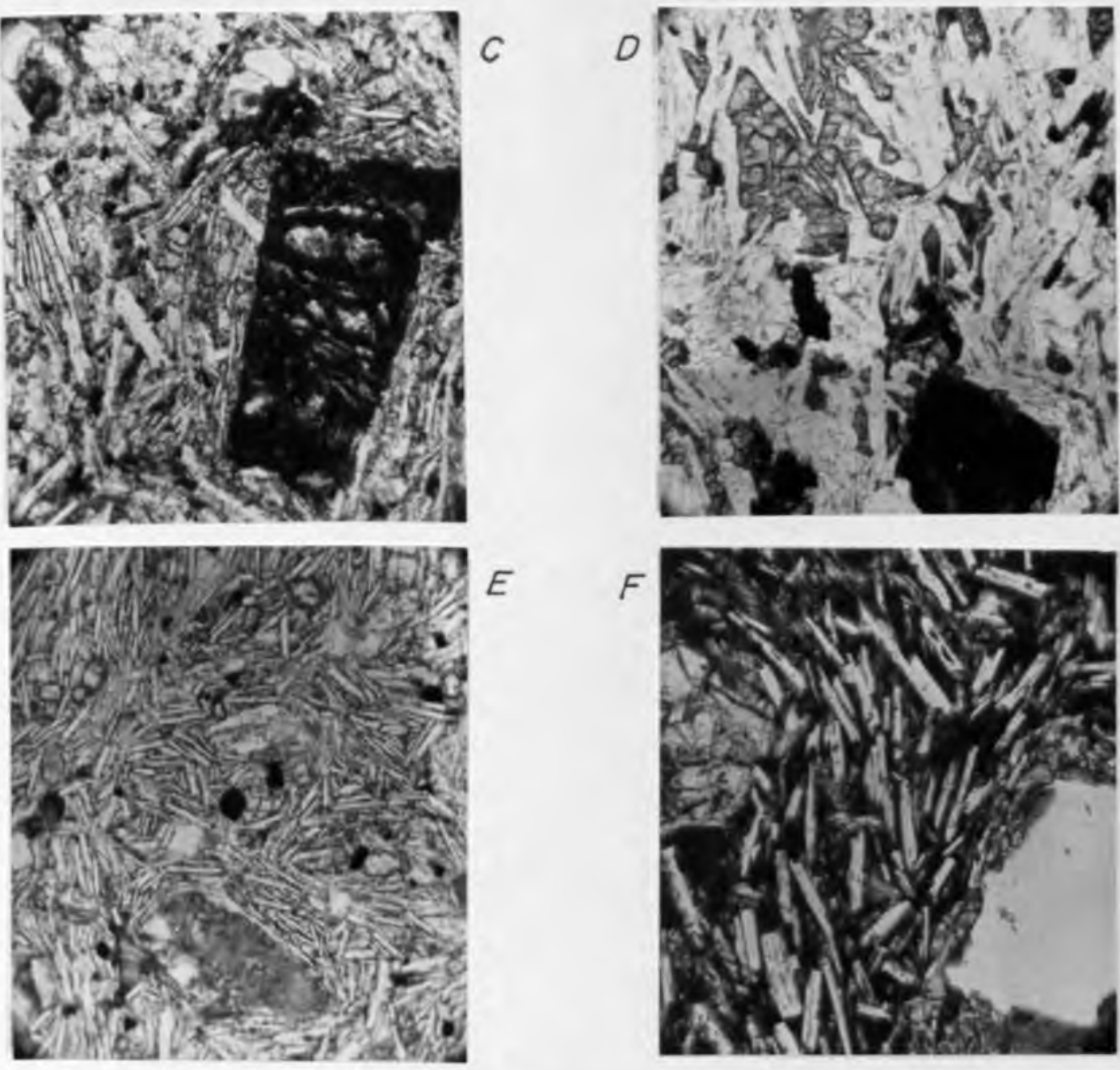
PIATE 21

328 


\section{IIATE 21}

PHOTONICROGRAPHS OF DACITE, MNDESITE, AID BASALT FLOW ROCKS

A, Porphyritic dacite Irom the Undifferentiated volcanic serles of middie Tertiary afe. Large crystal seems to be a xenocryst of andesine, with a more calcic border. Feldspar microlltes are labradorite. lific constituents are altered to nontronite(?) and iron ores. Guartz occurs rarely. Specinon F-42-54; plane-volarized lieht.

B, Olivine and hypersthene basalt from the upper part of the Balsns clastic Eroup. lost of the olivine has sone to 1ddingsite and scrpentine. Hypersthene occurs as phenocrysts with altered ollvine and feldspar; augite 1s disseminated throush the matrix. Feldspar phenocrysts are as calcic as bytomite, but microlites are labradorite. Chlorite is common in the petrix. Specimen F55-24; plane-polerized Iight.

$C$, Porphyritic dacite gimilar to $A$, above, from the same area. Crystal on tho right is quartz. Specimen $\mathrm{F}-43-54$; plane-polarized IIght.

D, Porphyritic andesite dike rock cuttine the Tilzapotla rhyolite serics. Rock contalns a few scattered phenocrysts of highly altered homblende, like that at the bottom of the photograph. Vatrix 1s devitrified Glass with labradorite microlites. Specinen F55-20; plane-polarized Iight.

E, Dacite flon rock fron the base of the Buenavista volcanta series. Rock contains abundant hornblende tablets, altered lareelj to iron ore. Feldspar microlites are lebradorlte. embedded in a mesostasis of devitrifled(?) Blass. Specimen II55-19; plane-polarized 11Eht.

F, Idainssite basalt overlying or interbedded wh the BaIsas clastic group. Rocle contains rere scattered quartz Grains. Olivine phenocrysts liave sone to iddinsite and 1ron ore. Feldspar microlites are labredorite. Vatrix contains prisms of augite and hypersthene(?). Chlorite is present in minor amount. Specimen F55-33; plane-polarized light. 
PLATE 21
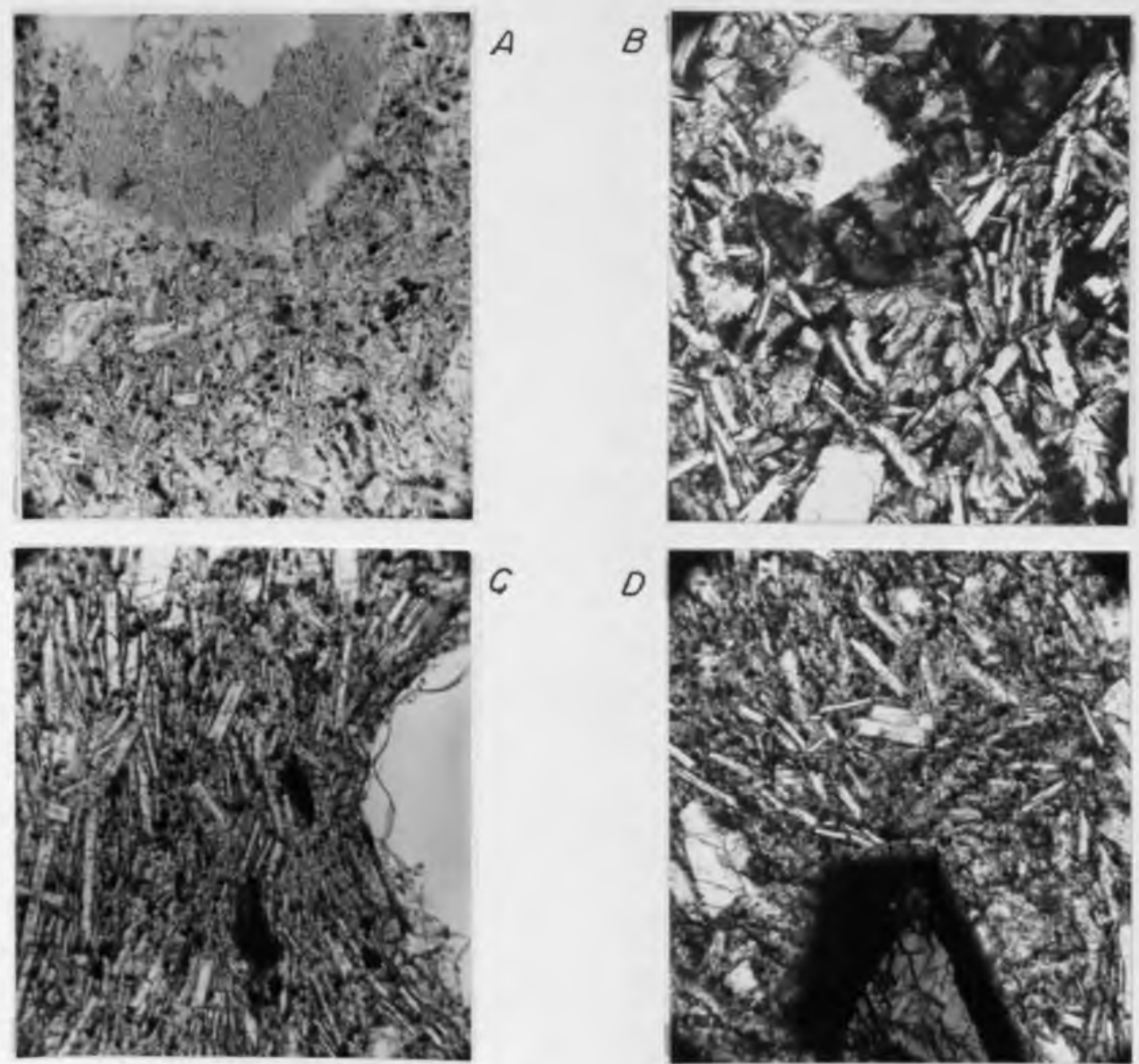

c

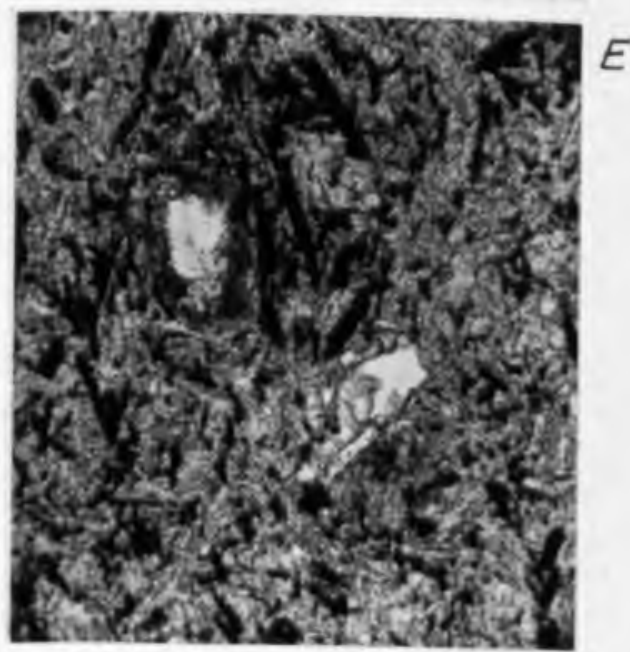

D
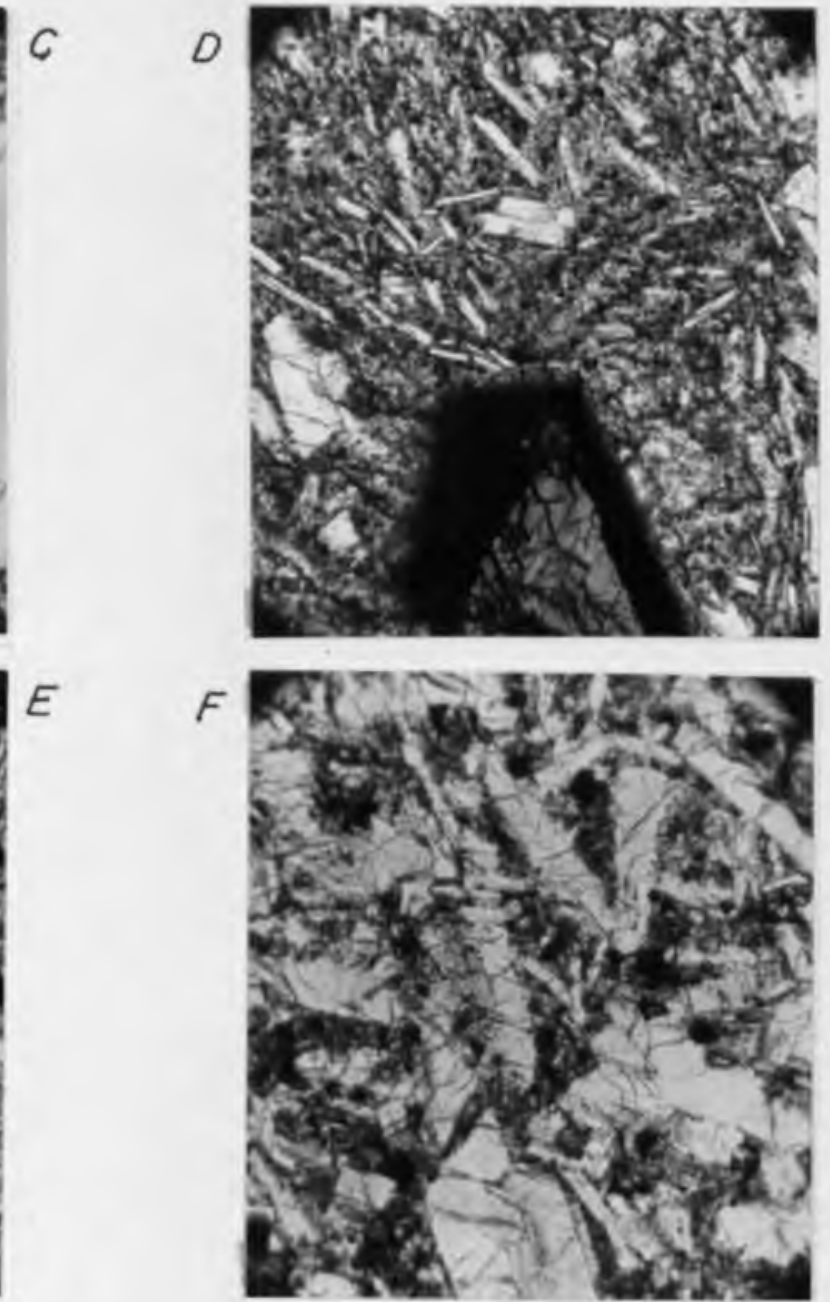
PIATE 22

329 
PLATE 22

\section{PHOTONICROGRAPHS OF OIIVIHE PASALT FIOU ROCKS}

A, Olivine basalt from the Chlchineutzin baselt series. Part of the olivine is altered to 1dainssite. Feldspar microlites are bytowite. Witrix conta1ng $\varepsilon$ little glass and abundant scattered srains of augite. Specimen F-34-54; planepolarlzed I1sht.

E, Olivine basalt from the Chichinautzin basalt series. P1Iotaxitic texture characterizes the Eroundmass, rhich contains abundant scattered aurite grains. Rims of serpentine surround most of the olfvine phenocrysts, but rock seneraliy shows little alteration. Feldspar microlites are labrador1te. Specimen F-I-50; plane-polarized light.

C, Olivine basalt from the Cilichinautzin basalt series. OlIvine and pyroxene phenocrysts are present, the former altered to idaingsite around the rims, and the latter altered to dark-brown plgeonite(?). Feläspar microlites are bytowIte and occur w1th augite Era.1ns. Specisen F-10-50; planepolarized light.

D, Olivine and ausite basalt from the Chichinautzin basalt serles. Both olivine and ausite occur as abundant phenocrysts and are Eenerally fresh. The rock has a porphyritic, pllotaxitic texture. Vatrix feldspar microlites are labradorite and occur with abundant augtte Erains. Rocle is fresh and unaltered. Specimen F-50-54; plane-polarized light.

is, Olivine baselt from the Chlchinautain basalt series. OIIvine phenocrysts make up about one-fourth of the rock and are perfectly eresh. Rock has porphyritic and ophltic to p1lotaxitic texture. Felasper microlltes are labradorite and occur with abundant augite Erains. Specimen F-4-50; plane-polarized I1Eht.

F, Olivine basalt from the Chichinautain basalt series. Rock contains glomerophenocrysts of olivine and some plesioclase. Texture is porphyritic, inyalopilitic. Groundanss feldspar microlites are bytomite to lebradorite and occur with abundant ausite Erains. Rock is generally fresh. Specinen F-3-50; plane-polarized lisht. 
PLATE 22
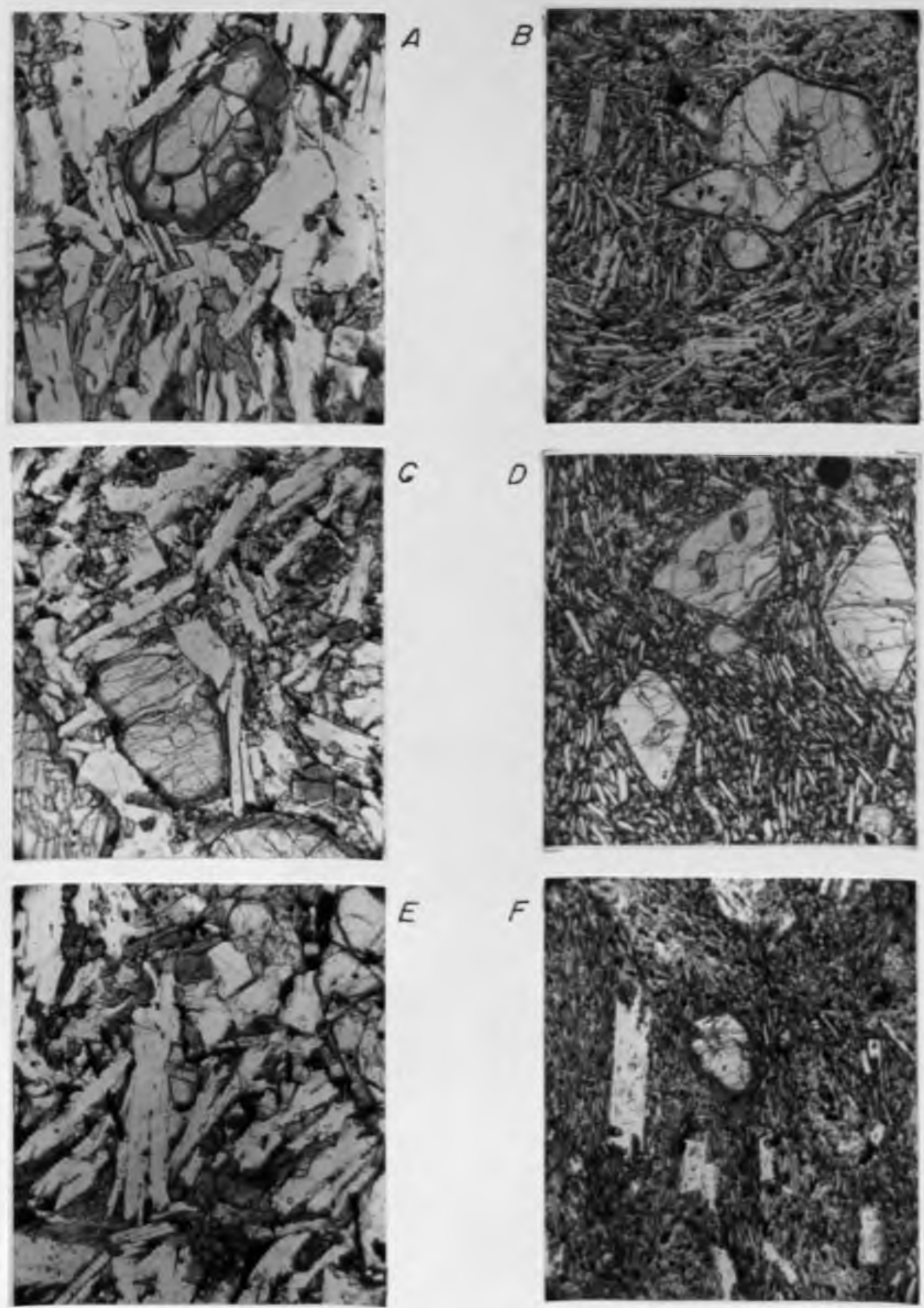

$\times 70$

$0.5 \mathrm{~mm}$ 


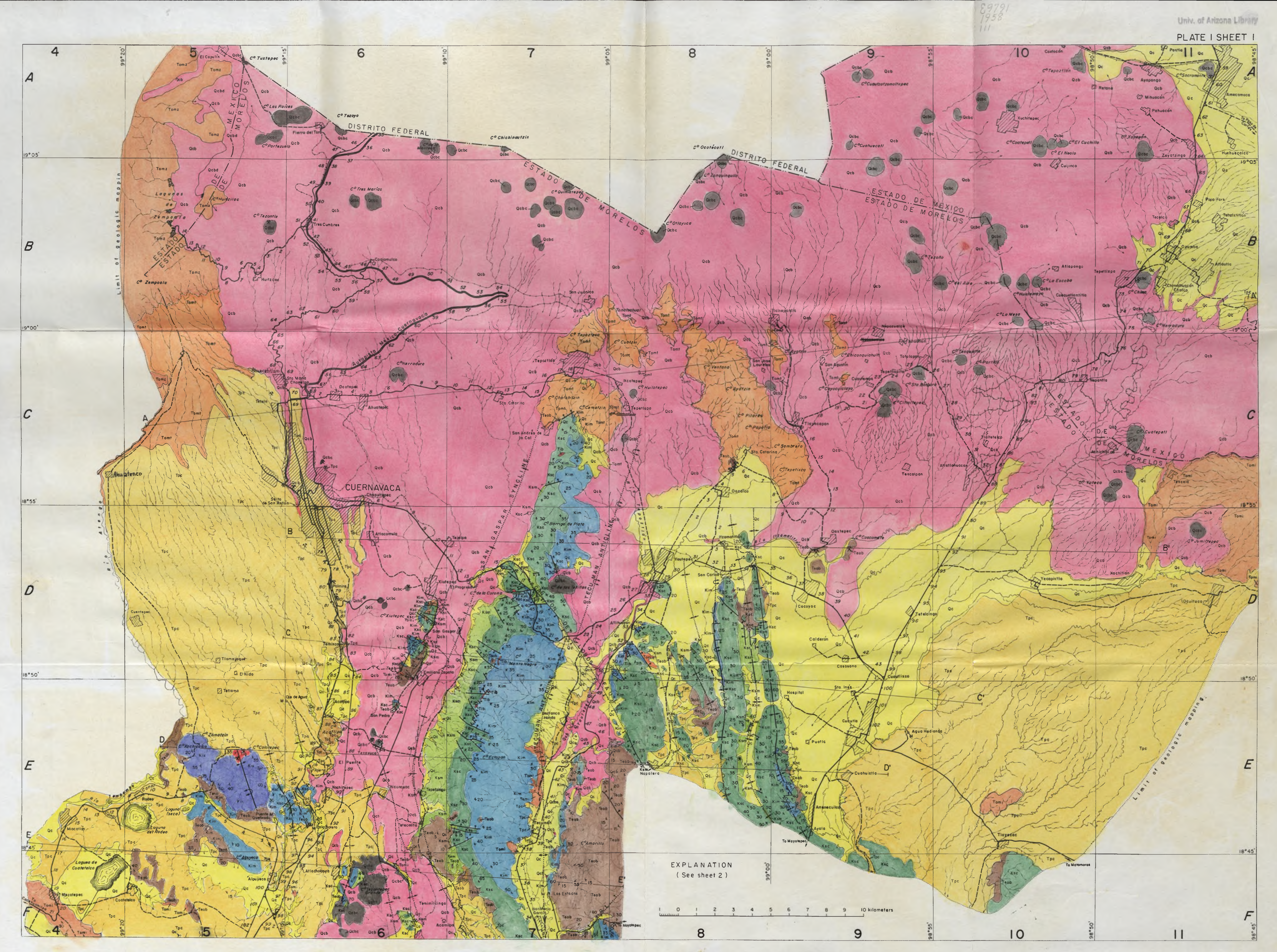




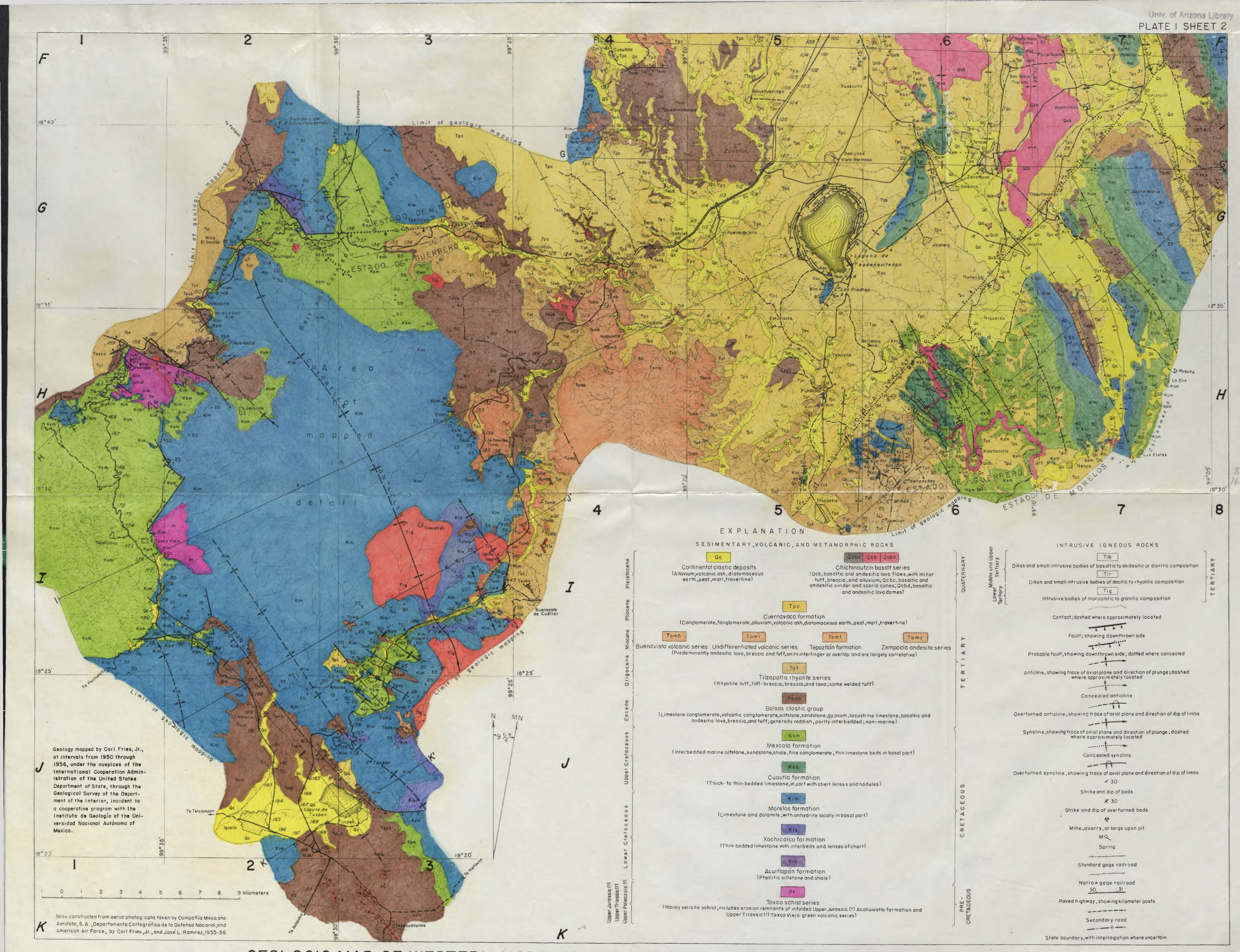

GEOLOGIC MAP OF WESTERN MORELOS AND EXTREME NORTH-CENTRAL GUERRERO, MEXICO 


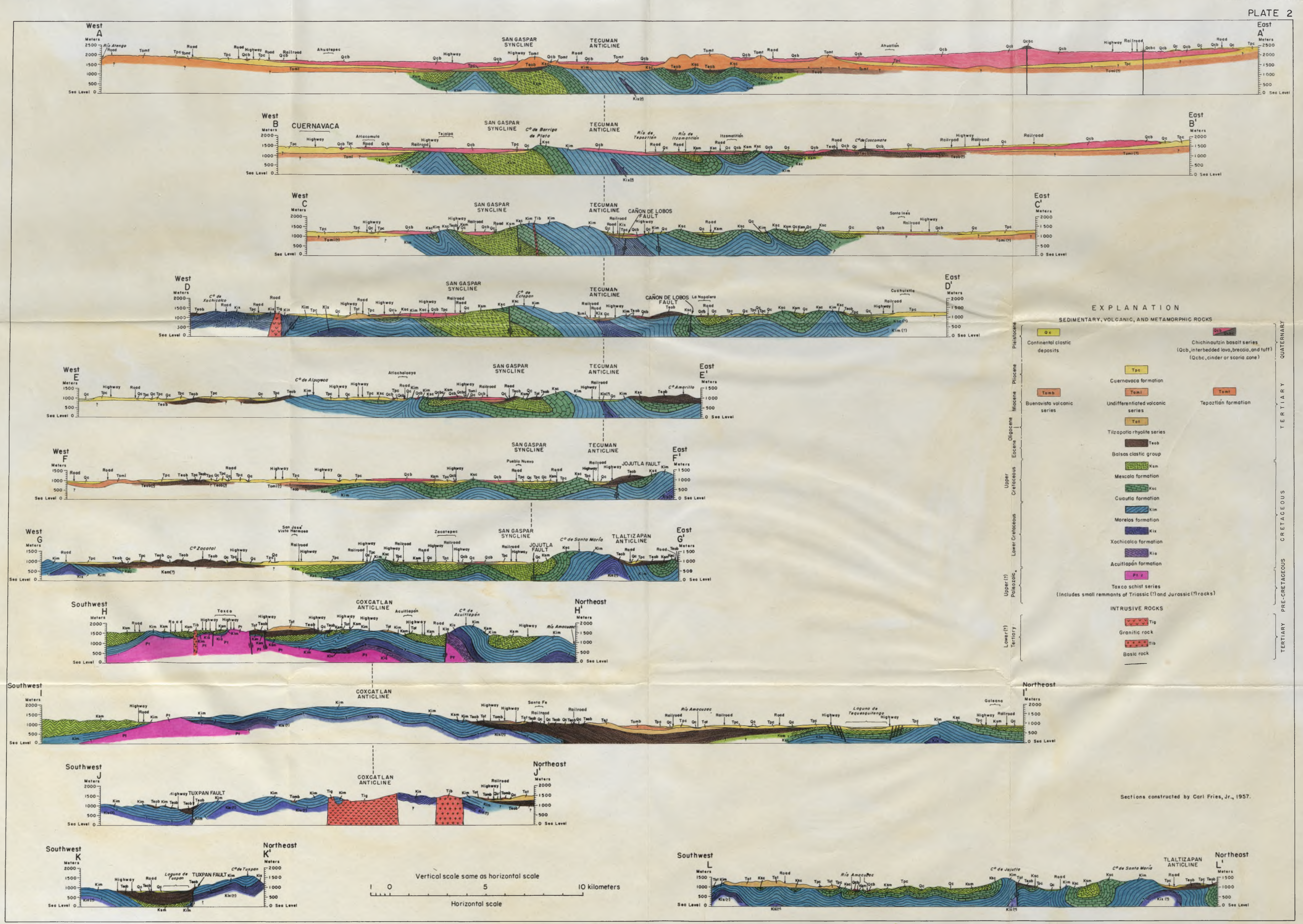

GEOLOGIC SECTIONS THROUGH WESTERN MORELOS AND NORTH-CENTRAL GUERRERO, MEXICO 


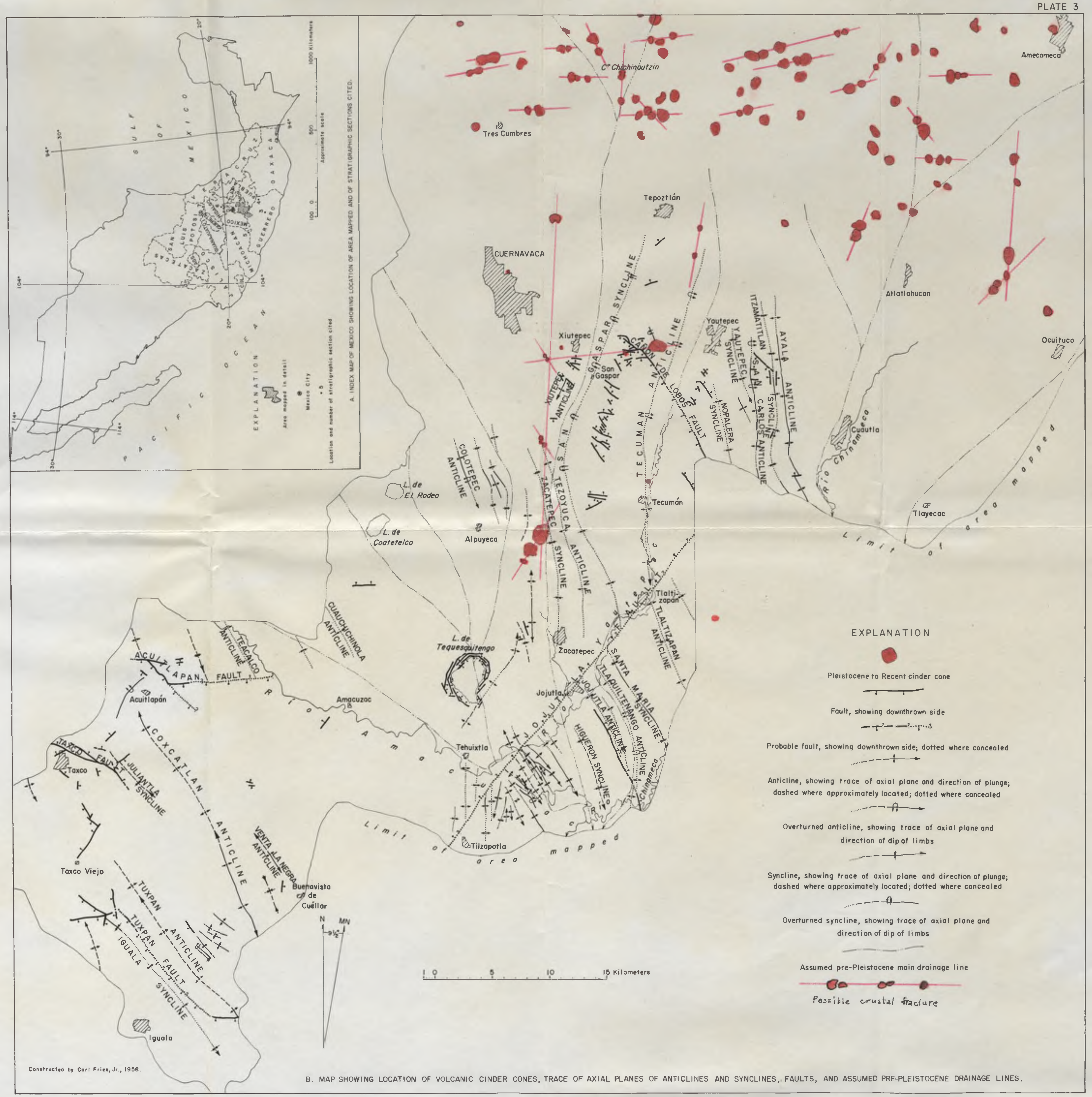

